\title{
STUDIA POLITOLOGICZNE
}

\section{INP}

- Wydział Nauk Politycznych

i Studiów Międzynarodowych
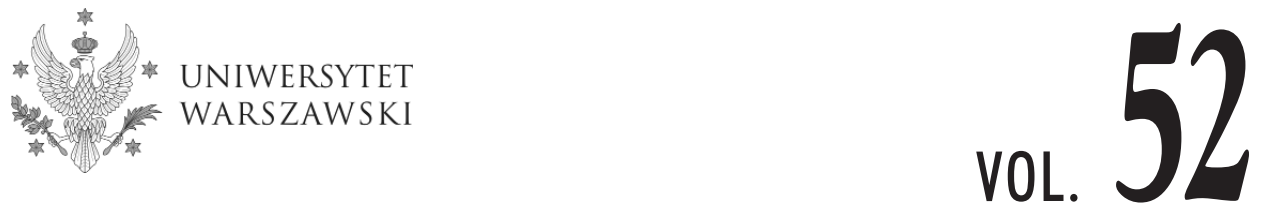


\section{POLITICAL SCIENCE STUDIES}

\section{CONSTITUTIONAL CHALLENGES OF EASTERN EUROPEAN COUNTRIES}

edited by Stanisław Sulowski and Jacek Zaleśny 


\section{STUDIA POLITOLOGICZNE}

\section{(,ПОЛИТОЛОГИЧЕСКИЕ ИССЛЕДОВАНИЯ”)}

КОНСТИТУЦИОННЫЕ ВЫЗОВЫ

СТРАН ВОСТОЧНОЙ ЕВРОПЫ

Редакция: Станислав Суловски, Яцек Залесны 
Rada Naukowa Stanisław Filipowicz (Uniwersytet Warszawski)

Ks. Helmut Juros (Uniwersytet Kardynała Stefana Wyszyńskiego)

Rubén Torres Kumbria (Universidad Nacional de Educación a Distancia)

Gerd Meyer (Eberhard Karls Universität Tübingen)

Szewach Weiss (University of Haifa)

Jan Zielonka (University of Oxford)

A. Ju. Szutow (Moskiewski Uniwersytet Państwowy)

Redaktorzy Administracja publiczna: Grzegorz Rydlewski (Uniwersytet Warszawski)

tematyczni Badania wschodnie: Tadeusz Bodio (Uniwersytet Warszawski)

Studiów Bezpieczeństwo: Andrzej Misiuk (Uniwersytet Warszawski)

Politologicznych Historia polityczna: Wojciech Jakubowski (Uniwersytet Warszawski)

Integracja europejska: Konstanty A. Wojtaszczyk (Uniwersytet Warszawski)

Myśl polityczna: Tomasz Żyro (Uniwersytet Warszawski)

Parlamentaryzm współczesny: Tadeusz Mołdawa (Uniwersytet Warszawski)

Polityki sektorowe: Agnieszka Rothert (Uniwersytet Warszawski)

Psychologia i socjologia polityki: Jan Garlicki (Uniwersytet Warszawski)

Ruchy społeczne: Grażyna Ulicka (Uniwersytet Warszawski)

Systemy polityczne: Zbigniew Kiełmiński (Uniwersytet Warszawski)

Teoria polityki: Mirosław Karwat (Uniwersytet Warszawski)

Komitet Stanisław Sulowski (redaktor naczelny)

Redakcyjny Ewa Maria Marciniak (zastępca redaktora naczelnego)

Daniel Przastek (członek)

Włodzimierz Ulicki (członek)

Jacek Zaleśny (sekretarz)

Redaktorzy językowi: Eva Allen, Halina Maczunder, Ewa Rydlewska, Izabela Kraśnicka-Wilk, Ekaterina Kolb

Redaktor techniczny: Marta Grabarczyk

Redaktor statystyczny: dr Viera Gafrikova

„Studia Politologiczne” znajdują się w wykazie czasopism naukowych prowadzonym przez Ministra Nauki i Szkolnictwa Wyższego na potrzeby oceny jednostek naukowych z przyznaną liczbą 13 punktów.

„Studia Politologiczne” są dostępne w bazach danych: CEJSH, Index Copernicus, Erih Plus.

Czasopismo recenzowane przez recenzentów zewnętrznych.

Wersja pierwotna czasopisma: papierowa.

www.studiapolitologiczne.pl

(C) Copyright by Instytut Nauk Politycznych Uniwersytetu Warszawskiego, Warszawa 2019

ISSN 1640-8888

Nakład 600 egz.

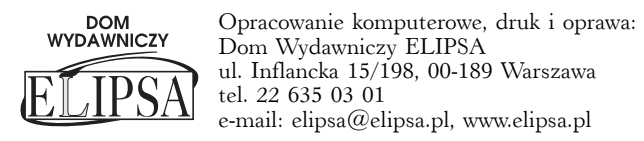




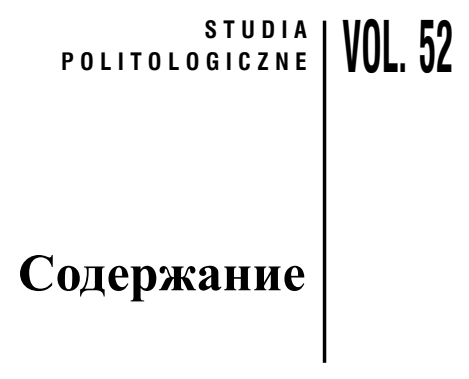

Введение..................................... 9

ИССЛЕДОВАНИЯ И АНАЛИЗ

Алла Соколова

Новые смыслы правовой политики: современные вызовы и перспективы. ............................. 11

Вениамин Евгеньевич Чиркин

Современные федерации и основные конституционные признаки федеративного государства . ....................... 26

Наталья Михайловна Кондратович,

Татьяна Станиславовна Масловская

Конституционные преобразования в странах СНГ и Западной

Европы: эволюционная необходимость или ответ современным

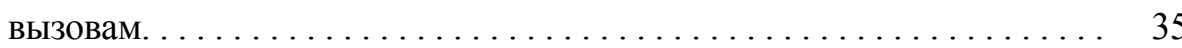

Омон Закирович Мухамеджанов

Усиление роли конституционного правосудия в защите прав

и свобод человека: основные тенденции, проблемы и перспективы. . 50

Оксана Владимировна Кукуруз

Трансформация общества: теоретико-методологические подходы

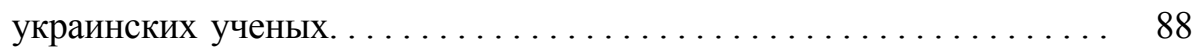

Михаил Иванович Пастухов

Система органов власти в Республике Беларусь: правовые основы,

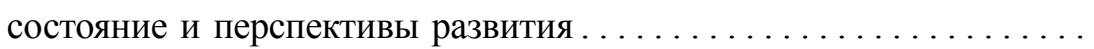

Мереке Габдуалиев

Трансформация президентской власти в Казахстане: выбор между демократией и социально-политической стабильностью . . . . . 117

Шахзод Алихонович Сайдуллаев

Вопросы совершенствования научно-теоретических

и методологических основ нормотворческой деятельности

в Республике Узбекистан на фоне зарубежного опыта . . . . . . . 132

Виталий Викторович Гончаров

Особенности правового регулирования общественного контроля в Российской Федерации на федеральном, региональном 
и муниципальном уровнях (конституционно-правовой

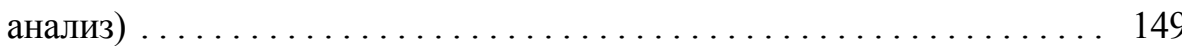

Александр Игоревич Черкасов

Конституция 1993 г. и местное самоуправление

в Российской Федерации. . . . . . . . . . . . . . . . . . . . . 163

Андрей Валерьевич Гавриков

Политические партии Республики Беларусь и Республики Польша

(политико-правовой аспект становления). . . . . . . . . . . . 176

\section{Яцек Залесны}

Конституционное право Европейского союза как объект научных исследований . . . . . . . . . . . . . . . . . . . . . . . . . . . . . . . . . . . . . . . 187

Аскар Мирсаидов

Международно-правовые аспекты вступления Узбекистана в ВТО

в контексте обзора законодательства в области торговли услугами. . 200

Anahit Manasyan

The Issues of Differentiation of Constitutional Policy from Ongoing

Politics. . . . . . . . . . . . . . . . . . . . . . . . . . . . . . . . . 218

\section{Dobrochna Minich}

Problems of Interpretation of Law in Accordance with the Constitution

- Polish Construction in Historical and Comparative Aspects . . . . . . . . 227

Tomasz Koziełło

Changes in Political Relevance of The League of Polish Families

in Result of Parliamentary, Municipal and European Elections . . . . . . 239

Aneta Dawidowicz

A Dispute Between "the Younger" and "the Older" about the Economic Model of the National Movement Between 1928 and 1939 (Arguments

Exchanged in the Press).

РЕЦЕНЗИЯ НА КНИГУ

Нурсултан Абишевич Назарбаев, Эра независимости (Albert

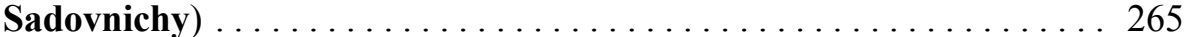

Авторы ............................... 271 


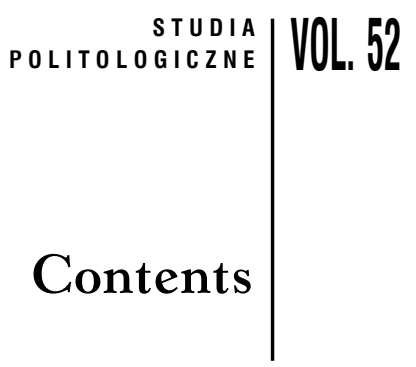

Introduction . . . . . . . . . . . . . . . . . . . . . . . . . . 9

\section{STUDIES AND ANALYSIS}

\section{Alla Sokolova}

New Meanings of Legal Policy: Contemporary Challenges

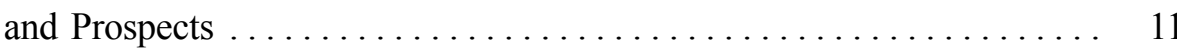

Veniamin E. Chirkin

Modern Federations and Main Constitutional Signs of the Federal State 26

Natalia M. Kondratovich, Tatiana S. Maslovskaya

Constitutional Transformations inthe Cis and Western Europe:

An Evolutionary Need or Response to Modern Challenges.......... 35

\section{Omon Zakirovich Mukhamedzhanov}

Strengthening the Role of Constitutional Justice in the Protection

of Human Rights and Freedoms: Main Trends, Problems

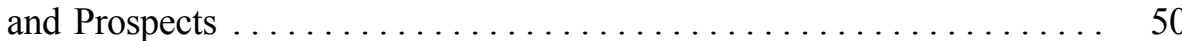

Oksana Vladimirovna Kukuruz

Transformation of Society: Theoretical and Methodological

Approaches of Ukrainian Scientists . . . . . . . . . . . . . . . . 88

Mikhail Ivanovich Pastukhov

The System of Authorities of the Republic of Belarus: Legal Framework,

State and Development Prospects...................... 99

\section{Mereke Gabdualiyev}

Transformation of Presidential Power in Kazakhstan:

The Choice Between Democracy and Socio-Political Stability ........ 117

\section{Shahzod Alikhonovich Saydullaev}

Issues Improvement of Scientific-Theoretical and Methodological

Basis of Rule-Making Activity in the Republic of Uzbekistan Against

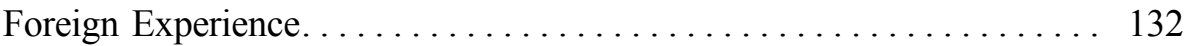

Vitaly Viktorovich Goncharov

Features of Legal Regulation of Public Control in the Russian

Federation at the Federal, Regional and Municipal Levels

(Constitutional and Legal Analysis) .......................... 149 


\section{Alexander I. Cherkasov}

Constitution of 1993 and Local Self-Government in the Russian Federation .

Andrey Valerievich Gavrikov

Political Parties of the Republic of Belarus and the Republic of Poland (Political and Legal Aspect of Formation).

Jacek Zaleśny

The Constitutional Law of the European Union as an Object of Scientific Research

Askar Mirsaidov

International Legal Aspects of the Accession of Uzbekistan to the WTO in the Context of the Review of Legislation on Trade in Services.

Anahit Manasyan

The Issues of Differentiation of Constitutional Policy from Ongoing Politics. . .

\section{Dobrochna Minich}

Problems of Interpretation of Law in Accordance with the Constitution

- Polish Construction in Historical and Comparative Aspects . .

\section{Tomasz Koziełlo}

Changes in Political Relevance of The League of Polish Families

in Result of Parliamentary, Municipal and European Elections . . . . . . . 239

\section{Aneta Dawidowicz}

A Dispute Between "the Younger" and "the Older" about the Economic Model of the National Movement Between 1928 and 1939 (Arguments Exchanged in the Press) ............................ 251

BOOK REVIEW

Нурсултан Абишевич Назарбаев, The Era of Independence (Albert

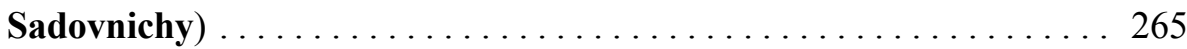

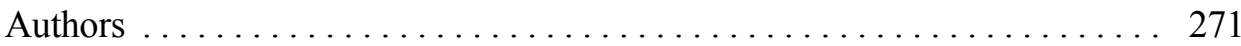




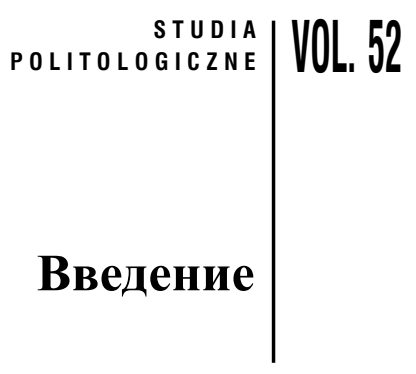

52 том «Политологических исследований» посвящен конституционным вопросам в государствах Восточной Европы. Как утверждают авторы размещенных в нем исследований, основное значение для функционирования политических институтов государства имеют три группы вопросов. Первая связана с нормативным измерением - каким образом законодатель спроектировал отдельные институты; как он обозначил существующую между ними структурно-функциональную зависимость; каких результатов он желал таким образом достичь. Вторая - с практикой реализации государственного устройства - каким содержанием наделяется каждый отдельный институт участниками политических отношений; в каких рамках и с какой интенсивностью практика следует за правовыми нормами (прежде всего, конституционного уровня), а в каком аспекте пытается их обойти, пренебречь, либо другим образом исказить, или же - усматривая неадекватность, архаичность правовых регулирований, приспособить их (путем применения разного рода методов толкования права) к изменчивым политическим обстоятельствам. И, наконец, третья - с размышлениями на тему государственного устройства - какое влияние внешних, негосударственных факторов, и связанные с ними изменения, как в рамках правовых актов, так и практики государственного устройства. Данная третья группа отчасти пренебрегается в анализе вопросов государственного устройства современных государств, однако, имеет ключевое значение. Достаточно упомянуть вопрос механизмов возникновения так называемых «цветных революций» в постсоветских и арабских государствах. Были ли они результатом политического поведения граждан каждого из государств, в которых произошли так называемые «цветные революции», радикальной попыткой приведения в соответствие практики государственного устройства конституционным образцам, или же - соответственно - желанием перемены тех же конституционных образцов? Возможно также, как утверждают некоторые из исследователей устройства современных государств, их приводную систему необходимо искать за пределами территорий отдельных государств, в попытке свершения политических изменений, желаемых основными участниками международных отношений, изменений, вписывающихся в процессы глобализации международных отношений? Стремясь к целостному изучению происходящих политических 
процессов, не стоит избегать постановки таких исследовательских вопросов и поиска ответов на них.

Размещенные в представленном 52 томе «Политологических исследований» статьи касаются различных аспектов политического устройства государств Восточной Европы, сложности политических явлений, происходящих в данном регионе, их многоаспектности. Как убеждают авторы, устройства государств Восточной Европы невозможно свести до звучания текста их конституции или же к отдельным проявлениям политической деятельности. Они значительно более сложны, и именно в таком аспекте авторы рассматривают данное явление в предлагаемых ими текстах.

Приглашаем к прочтению!

Станислав Суловски, Яцек Залеснь 


\title{
Новые смыслы правовой политики: современные вызовы и перспективы
}

\author{
КЛЮЧЕВЫЕ СЛОВА: \\ правовая/ законотворческая политика, сочиальная природа \\ правообразования, публичная сфера, мультипликации субъектов \\ правотворчества, искусственный интеллект
}

\section{Введение}

Социальная картина мира в XXI веке кардинально изменилась: формирование постиндустриального и информационного общества, вызовы глобального мира поставили новые проблемы перед человечеством. Особую значимость в преодолении вызовов, разработке стратегии развития общества приобретает правовая политика, в комплексном своем проявлении оказывающая воздействие на все сферы современного общества. В последние десятилетия теоретические вопросы правовой политики стали предметом исследования ряда ученых ${ }^{1}$; особое внимание обращается на необходимость разработки официального программного документа - Концепции правовой политики ${ }^{2}$. Менее исследованным в юридической литературе является, на мой взгляд, вопрос о публичности правовой политики, степени вовлеченности граждан, общественных объединений, иных институтов гражданского

1 См., например, И. А. Кулажников, Социальная правовая политика Российского государства. Автореф. дис. канд. юрид. наук., Ростов-на-Дону 2005; Н. И. Матузов, А. В. Малько (ред.), Правовая политика: теория и практика: Монография, Москва 2006; А. В. Малько, Теория правовой политики: Монография, Москва 2012.

2 См.: А. В. Малько, Правовая политика современного общества: от теории к практике, «Вісник Маріупольського державного університету, Серія: Право» 2012, Вип. 3-4, с. 10. 
общества в процесс определения ее стратегических направлений и приоритетов. В предлагаемой статье акцент будет сделан на особо значимой сфере правовой политики - законодательной деятельности. Большинство реформаторских задумок, национальных проектов, способов модернизации экономических и социальных конструкций сопряжено с попыткой надлежащего эффективного правового регулирования. Однако, десятилетние «искания» верного методологического ориентира в политике законотворческой деятельности в постсоветских государствах так и не привели к весомым результатам. Остаются очевидными проблемы качества современного позитивного права/законодательства, и усилия правоведов с неизменным усердием обращены к предметному полю его производства.

В качестве гипотезы выдвигаются тезисы о том, что новые смыслы законодательной политики должны, по мнению автора, находить проявление в трех основных направлениях: частичном «разгосударствлении» законопроектной деятельности, ее публичном характере, в реальном участии акторов гражданского общества в процессе принятия законотворческих решений; мультипликации субъектов правотворчества; использовании искусственного интеллекта в законотворческом процессе.

Теоретико-методологическими основаниями исследовательского замысла послужили концепция социальных полей (Пьер Бурдье), теория свободы (Леони Бруно), социологическая концепция формирования права (Алла Соколова). Под правовой политикой в контексте представленной статьи предлагается понимать «научно обоснованную, последовательную и системную деятельность государственных органов и институтов гражданского общества по созданию механизмов правового регулирования, по цивилизованному использованию юридических средств в достижении таких целей, как наиболее полное обеспечение прав и свобод человека и гражданина, формирование правовой государственности и высокого уровня правовой культуры и правовой жизни общества и личности» ${ }^{3}$. Предметное поле исследования - политика в области законодательной деятельности, в частности, законопроектной стадии законотворческого процесса.

\section{От этатистской к социальной природе права}

Определяющим вектором переосмысления содержания правовой политики является смена парадигмы научного и профессионального правопонимания: от восприятия права как нормативного предписания, исходящего

3 Там же, с. 8. 
от государства (в своем крайнем этатистском проявлении - своеобразной государственной монополии на производство закона) в духе позитивистской теории права, к утверждению социальной природы права и сощчиальнылх истоков его формирования.

Социологическая юриспруденция исходит из признания социального контекста зарождения, моделирования, действия правовых норм с надлежащим образом государственно-организованной их фиксацией и обеспечением. Согласно авторской концепции, в процессе формирования права можно условно выделить три этапа: 1) определение объективных потребностей в правовой регламентации общественных отношений; 2) правотворчество (установление правовых норм); 3) социализация правовых норм. Первый этап характеризуется созданием потенциальной возможности появления определенной модели поведения участников общественных отношений. На втором этапе осуществляется превращение возможности в реальные правовые нормы посредством их позитивации государственными структурами. Третий этап (социализация правовых норм) завершает процесс правового созидания реальной «жизнью», действием правовых норм в конкретных правовых отношениях; сопровождается наступлением для участников социального общения правовых последствий, отвечающих их интересам или противоречащих им. В целом результатом этого этапа может оказаться ожидаемый членами общества правовой порядок, и тогда будет позволительно констатировать, что установленные в различных формах (законах, указах, постановлениях и т. д.) правовые нормы есть право. В противоположном случае - в ситуации правового «беспорядка», юридической конфликтности, нарушения прав и свобод граждан и многих других обстоятельств - можно констатировать эффект создания произвола/неправа/квазиправа. Таков вкратце ход длительного процесса социальной трансформации и рождения права 4 .

Возникает важный для определения вектора развития законодательной политики вопрос: кто является творцом права, закона? Разумеется, в контексте признания государственной власти источником формирования права нормативное предписание может проистекать из произвольных актов государственной власти, нацеленных на его законодательное закрепление и формулировку.

Если исходить из социолого-правового посыла: источник правовой нормы заложен не столько в воле автора (законодателя), сколько в жизненной потребности, которую правило призвано удовлетворить, можно гипотетически предположить, что институты гражданского общества с большей очевидностью смогли бы выразить и обеспечить те социальные отношения,

4 См.: А. А. Соколова, Социальные аспекты формирования права, Минск 2003. 
которые являются для них повседневными, профессиональными, иными; создавать модели поведения в максимальной степени отвечающие интересам участвующих в них сторон 5 .

Попытаемся теоретически проследить путь формирования правовой нормы и определить круг участников на каждом из его этапов.

Начало правообразовательного процесса связано с выявления объективных потребностей правового регулирования. Учитывая огромный массив не всегда обусловленных реальными нуждами и создающих проблемы в правоприменительной практике нормативно-правовых актов, правовая политика должна включать солидные научно-исследовательские мероприятия по определению предметного поля будущего правового акта, выявлению и учету системы социальных факторов (экономических, политических, экологических и т.д.), определению круга заинтересованных в новом акте лиц, направленность их интересов, процедуру согласования при существенных разногласиях, действия по прогнозированию правовых последствий и социальной эффективности. Иными словами, речь идет о разработке концеепции проекта будущего правового акта, основная роль в которой принадлежит государственным институтам. Но только ли? С точки зрения социальной обусловленности правообразования в этом процессе должны участвовать и реально участвуют, в зависимости от степени зрелости гражданского общества, развитости демократии, правовой культуры, политических традиций, иные социальные институты (политические партии, общественные организации, граждане). Не приобретает ли законотворческая политика резонный смысл в исследовании степени вовлеченности сочцальных институтов в прочесс формирования права 6 .

Второй этап процесса создания права связан преимущественно с государственными органами, за которыми официально закреплена функция позитивации права - установления в особой процедуре нормативно-правовых актов, придания им юридического общеобязательного характера. Возможно ли привлечение институтов гражданского общества к участию в этой деятельности: разработке проекта правового решения, его всемерного обсуждения?

Третий этап логически завершает процесс формирования права и состоит в адаптации новых моделей поведения общественным и профессиональным

5 А. А. Соколова, Личность, общество, государство: проблемы правового общения, [в:] В. Г. Графский (отв. ред.), Современное государство и личность в историческом и философско-правовом осмыслении: сборник материалов двенадцатых философскоправовых чтений памяти академика В. С. Нерсесянца, Москва 2018, с. 22.

6 А. А. Соколова, Правовая политика в публичном измерении: направления развития, [в:] В. В. Смирнов (отв. ред.), Сборник материалов Всероссийской конференции «Правовая политика в условиях модернизаџии» 19 ноября 2010 г., Москва 2011, c. $167-176$. 
правосознанием, включением в мир правовых отношений, реальным действием и приведением к правовому порядку в социальной среде. В авторской концепции он обозначен как социализация правовых норм.

Возникает резонный вопрос: кто же эти анонимные силы, участвующие в конструировании права и в чем проявляется их правотворческое участие? На этот вопрос резонный ответ дал П. Бурдье: «настоящим законодателем является не автор проекта закона, но все те агенты, которые, выражая специфические интересы и обязательства, ассоциируемые с их положением в различных полях (в юридическом поле, но также в религиозном, политическом и так далее), сначала вырабатывают частные и неофициальные устремления и требования, а затем придают им статус «социальных проблем», организуя с целью их «продвижения» формы публичного волеизъявления (статьи, книги, платформы ассоциаций или партий) и давления (манифестации, петиции, требования)»7. П. Бурдье определяет причастных к производству права акторов: в его терминах, это «агенты» - персонал различных взаимосвязанных между собой соичиальных полей (политического, юридического, религиозного, экономического и других).

Итак, теоретическая реконструкция правовой политики, на мой взгляд, должна исходить из признания сощиальности конструирования права, как определяющем признаке его формирования, и участия в этом процессе акторов гражданского общества.

\section{Публичное пространство как арена для правового общения в законотворческом процессе}

Доктрина законодательной политики демократических государств строится на двух основных конституционных постулатах: единственным источником государственной власти признается народ; народ осуществляет свою власть непосредственно и через представительные и иные органы (статья 3. Конституции Республики Беларусь). «Граждане Республики Беларусь имеют право участвовать в решении государственных дел как непосредственно, так и через свободно избранных представителей» (статья 37. Конституции Республики Беларусь $)^{8}$. В законодательной сфере правовое взаимодействие личности и государства преимущественно осуществляется посредством

7 П. Бурдье, Социальное пространство: поля и практики, Н. А. Шматко (пер. с франц.; отв. ред. перевода, сост. и послесл.), Москва, Институт экспериментальной социологии, СПб 2005, с. 114.

8 Конституция Республики Беларусь 1994 года (с изменениями и дополнениями, принятыми на республиканских референдумах 24 ноября 1996 г. и 17 октября 2004 г.), 
представительной демократии - выборов электоратом своих представителей в законодательный орган. Этот факт сам по себе не гарантирует высокой степени учета требований и интересов избирателей в принимаемых законодательными органами решениях. В отсутствии культуры демократических процедур соучастия граждан в законодательном процессе, легитимность многих не оправдывающих ожидания избирателей законодательных актов небесспорна. В отличие от представительной, прямая демократия, как способ принятия правовых решений гражданами, - более эффективна, но часто ли прибегает к ней государство и всегда ли она уместна?

Насколько безупречна в современных реалиях представительная демократия как форма установления правовых моделей поведения? Существуют ли иные способы достижения гармонии и солидарности в разрешении проблем правовой повседневности? Как модернизировать теорию закона или противопоставить ей новую, основанную на иных теоретических доминантах? Этот комплекс вопросов, думается, требует осмысления и обсуждения и не только в академической среде, но и, в терминах Х. Арендт, Ю. Хабермас, публичном пространстве с участием акторов гражданского общества.

Указанные проблемы созвучны вопросу, поставленному итальянским исследователем XX века Б. Леони в своей книге «Свобода и закон», об убедительности и допустимости критики доктрины о том, что, «поскольку законы принимает парламент, избираемый народом, то народ является источником законодательного процесса, и воля народа или по крайней мере той его части, которая является электоратом, ... в конце концов восторжествует во всех вопросах, находящихся в ведении правительства»9. Выражает ли в реальности парламент «волю народа или по крайней мере той его части, которая является электоратом», какова в процентном отношении доля этой части электората, как быть с волей другой его части, которая не получила большинства на выборах? Справедливо в этом отношении утверждение Б. Леони: «...законодательство все больше и больше напоминает диктат победившего большинства законодательных собраний по отношению к меньшинству; результатом этого часто бывает то, что привычные ожидания людей опрокидываются, а на смену им приходят совершенно новые» ${ }^{10}$. Эти

http://pravo.by/pravovaya-informatsiya/normativnye-dokumenty/konstitutsiya-respublikibelarus/ (дата обращения: 20.01.2019).

9 Б. Леони, Свобода и закон, В. Кошкин (пер. с англ.), А. Куряева (пер. с англ. под ред.), Москва 2008, с. 120-121.

10 Конституция Республики Беларусь 1994 года (с изменениями и дополнениями, принятыми на республиканских референдумах 24 ноября 1996 г. и 17 октября 2004 г.), http://pravo.by/pravovaya-informatsiya/normativnye-dokumenty/konstitutsiyarespubliki-belarus/ (дата обращения: 20.01.2019). 
вопросы, по сути, есть выззовы современной законотворческой политике. Как теоретически реагировать на них?

Контуры/границы законодательной политики, на мой взгляд, должны выйти за пределы государственной деятельности. Теоретическим обоснованием для такого утверждения служат, во-первых, изменение восприятия приоритетности элементов в системе: «личность - общество - государство» при смене идеологической парадигмы в конце XX века (вместо традиционного взгляда с позиции советской идеологии: «государство - общество - личность»). Конституции постсоветских государств закрепили это положение, например, статья 2. Конституции Республики Беларусь провозглашает: «Человек, его права, свободы и гарантии их реализации являются высшей ценностью и целью общества и государства» ${ }^{11}$. Во-вторых, обновленный образ современного государства, представленный в юридической литературе, начиная с 90-х годов прошлого столетия, как «средства общественного компромисса, снятия или смягчения противоречий, механизм управления делами общества» ${ }^{12}$.

Задача современного демократического государства - установление правового порядка для поддержания в обществе мира, согласия, безопасности. Одной из моделей взаимодействия между личностью и государством может выступать формат правового взаимодействия («правового общения» - в терминах В. Г. Графского, Л. С. Мамута $\left.{ }^{13}\right)$, которое, по мнению В. Г. Графского, «...логично воспринимать нацеленным на обретение и поддержание общего блага как одного из воплощений справедливости» ${ }^{14}$. В философско-правовом аспекте «общее благо» можно усмотреть в надлежащем уровне правового регулирования, правового порядка, в которых равно заинтересованы и государство, и общество. Социальные институты, являясь площадкой для реализации личностью своих профессиональных, гражданских, всякого рода иных интересов и потребностей, наряду с государственными, выступают акторами правового общения. Выражая интересы и обязательства, соответствующие их положению в различных социальных полях (в юридическом, религиоз-

11 Конституция Республики Беларусь 1994 года (с изменениями и дополнениями, принятыми на республиканских референдумах 24 ноября 1996 г. и 17 октября 2004 г.) http:// pravo.by/pravovaya-informatsiya/normativnye-dokumenty/konstitutsiya-respubliki-belarus/ (дата обращения: 20.01.2019).

12 См.: Р. 3. Лившиц, Государство и право в современном обществе: необходимость новых подходов, «Советское государство и право» 1990, № 10, с. 16.

13 См.: В. Г. Графский, Правовое общение в прошлом и настоящем, «Право и политика» 2011, № 1; Л.С. Мамут, Правовое общение. Очерк теории, Москва 2011.

14 Конституция Республики Беларусь 1994 года (с изменениями и дополнениями, принятыми на республиканских референдумах 24 ноября 1996 г. и 17 октября 2004 г.) http://pravo.by/pravovaya-informatsiya/normativnye-dokumenty/konstitutsiya-respublikibelarus/ (дата обращения: 20.01.2019). 
ном, политическом, информационном, медийном и др.), они вырабатывают неофициальные требования, переводят их на уровень социальных проблем и организуют формы публичного волеизъявления для продвижения и реализации. Иными словами, речь идет об учреждении в публичном пространстве диалога равных акторов: институтов государства и институтов гражданского общества, которые, обмениваясь в целях удовлетворения общего для всех блага принадлежащими им социальными ролями, совместно участвуют в формировании правового решения. Каждая из сторон правового общения ответственна за выполнение сообща смоделированного, отвечающего взаимным ожиданиям и интересам решения, в замысле которого проявляется и признается инициатива каждой из них.

Таковы вкратце теоретические предпосылки модернизащии правовой/ законодательной политики, суть которой видится мне в придании публичности законотворческому процессу и частичном «разгосударствлении» законодательной деятельности: в реальном участии акторов гражданского общества в процессе разработки и обсуждения законопроектов.

Кто может быть признан актором законотворческих полномочий? В каких формах видится публичное волеизъявление их интересов? Прежде всего, стоит обратить внимание на необходимость расширения круга субъектов законодательной инициативы. В соответствии со статьей 99. Конституции Республики Беларусь, к ним относятся, помимо Президента, депутатов Палаты представителей, Совета Республики, Правительства, граждане, обладающие избирательным правом, в количестве не менее 50 тысяч человек ${ }^{15}$. На мой взгляд, в этот перечень резонно включить общественные объединения в лице их высших органов (это положение было установлено статьей 113. Конституции СССР 1977 года ${ }^{16}$ ). Общественные организации, в соответствии с профилем деятельности, используя опыт и инициативу своих членов, могут выступать инициаторами разработки новых или изменения действующих нормативно-правовых актов.

Признавая справедливость замечания Ж.-Л. Бержеля о том, что нельзя «...отрицать того факта, что именно компетентные органы государства в силу возможностей, которыми их наделяет само позитивное право, осуществляют выбор вариантов, предлагаемых, в свою очередь, тем самым обществом, которым управляют эти органы...» ${ }^{17}$, рассмотрим возможные варианты «разгосударствления» законопроектной деятельности.

15 Конституция Республики Беларусь 1994 года, http://pravo.by/pravovaya-informatsiya/ normativnye-dokumenty/konstitutsiya-respubliki-belarus/ (дата обращения: 20.01.2019).

16 См.: В. Г. Графский, Правовое общение в прошлом и настоящем, «Право и политика» 2011, № 1; Л.С. Мамут, Правовое общение. Очерк теории, Москва 2011.

17 Ж.-Л. Бержель, Общая теория права, Москва 2000, с. 240-241. 
Один из таких вариантов видится в широко используемом в практике советского государства, но требующем модернизации совместном создании правовых актов органами государства и общественными организациями по вопросам, представляющим взаимный интерес. В совместной правотворческой деятельности участвовали профсоюзы, комсомольские организации, потребительская кооперация, творческие союзы. При безусловно формальном характере, минимальной самостоятельности общественных организаций в правотворческих инициативах, превалировании роли руководящих органов общественно-политических организаций (ЦК КПСС, ЦК ВЛКСМ), пропагандистском характере многих совместных нормативно-правовых актов, оно имело принципиальный для правовой политики характер: государство оказывало доверие общественным организациям граждан, вовлекая их в законотворческий процесс.

Правовой статус общественных организаций в современных государствах определен конституциями, законами; цели, задачи, предметная область - уставами. Обзор некоторых из них позволяет сделать вывод о широкой сфере деятельности, зачастую совпадающей с государственной, однако выполняемой на добровольных началах, энтузиазме членами организации. Как не привлечь их к сотрудничеству по разработке моделей поведения в близкой для них области, к примеру, в кинематографии, журналистике, культуре, образовании, экологии и т.д.?

Многие современные демократические государства используют более эффективные по технологическому уровню формы участия граждан в законопроектной деятельности. Научно-технический прогресс в XXI веке сделал возможным использование Интернет как экономически эффективное средство не только для распространения информации и сбора идей от общественности, но и для ее активного участия в создании продукта государственной политики. Произошел качественный переход от пассивных форм восприятия общественностью информации к более активным: к культуре сопричастности процессу выработки решений - используемой в странах Европы, США практике краудсорсинга (Crowdsourcing), созданию текстового документа заинтересованными гражданами в сети Интернет ${ }^{18}$. Суть краудсорсинга в законопроектной деятельности - в совместном конструировании модели поведения в требующей правовой регламентации ситуации, в разработке текста проекта нормативно-правового акта коллективными усилиями участников сетевого проекта. Практика краудсорсинга имеет более завершенную форму

18 См.: А. А. Соколова, Демократическая культура в законопроектной деятельности: практика «Crowdsourcing», «Юридическая техника: Законотворческая, интерпретационная, правоприменительная техника в контексте культуры и межкультурной коммуникации», Нижний Новгород, Ежегодник 2016, № 10, с. 299-301. 
участия акторов в правотворческой деятельности. Она особенно уместна, на мой взгляд, в решении общезначимых вопросов локального уровня в русле развития местного самоуправления и использования творческой активности населения.

Новый смысл законодательной политики усматривается в придании публичному пространству статуса арены для правового общения институтов государства и гражданского общества в законотворческом процессе. В диалоге равных акторов жизненный и профессиональный опыт граждан и институтов гражданского общества с большей очевидностью способствовал бы нормативному выражению и обеспечению разнообразных социальных потребностей, формированию моделей правового общения в максимальной степени отвечающим интересам сторон.

\section{Мультипликация субъектов правотворчества: постановка проблемы}

Другое направление модернизации правовой политики видится в мультипликации субъектов правотворчества. В учебной литературе под правотворчеством (нормотворчеством) понимается особая форма государственной деятельности, состоящая в установлении, изменении и отмене правовых норм. Следует различать два близких понятия «правотворчество» и «законотворчество». Результатом правотворческой деятельности являются нормативно-правовые акты различного вида. Законотворческая деятельность направлена на разработку и принятие законодательных актов. Субъектами правотворческих полномочий, например, в Беларуси, являются государственные органы и народ, непосредственно участвующий в референдуме по решению важнейших вопросов государственной и общественной жизни (ст. 73. Конституции Республики Беларусь) ${ }^{19}$. Исходя из признаваемой автором концепции социальной природы права, не стоит ли обратить внимание на способы негосударственного формирования моделей поведения? Обратиться к традиционным источникам права, потерявшим, к сожалению, свою жизненную энергию в современной законодательной сфере.

Рассмотрим с позиции социологии права культуру саморегулирования взаимодействий между индивидами в сферах деловых, корпоративных, экологических, культурологических и иных отношений. Вырабатываемые ими нормы, основанные на требованиях разума, принципах морали, нравствен-

19 http://jurtech.org/wp-content/uploads/2015/03/\%D0\%9C\%D0\%B0\%D0\%BA\%D0\%B5\%D1 \%82-10.pdf (дата обращения: 20.01.2019). 
ности, этики, имеют императивную значимость для исполнения в своем кругу. Следуя концептуальному подходу о правовом плюрализме (Е. Эрлих, Л. Петражицкий, Ж. Гурвич) и поддерживая идею о множестве негосударственных центров, генерирующих нормы поведения (предприятия, профсоюзы, политические партии, религиозные организации, общественные объединения, международные организации), можно согласиться с мнением ученых, которые в современной жизни допускают существование источников неформального права - негосударственного, неофициального. По мнению известного российского ученого А. В. Полякова, помимо права государственного (им установленного), в современном мире функционирует надгосударственное (международное и региональное), негосударственное право (каноническое, транснациональное), являющееся результатом самоорганизации и саморегулирования социальными акторами/социальными институтами (транснациональными компаниями, корпорациями, международными организациями и т.д. $)^{20}$. Он справедливо замечает, что «...существование права зависит не от государства как внешней принудительной инстанции, а от наличия таких социальных институтов, которые способны поддерживать унифицированные образцы поведения, представляющие собой определенные правила. Таким социальным институтом может являться государство (чаще всего и является), но могут существовать и над- и меж-, и внутригосударственные институты, создаваемые как всем гражданским обществом, так и его отдельными структурами (корпорациями, конфессиональными организациями, политическими, профессиональными, этническими группами)»21.

Возникает вопрос, как законодатель должен относиться к производству негосударственного права различными социальными институтами? Как использовать ценностный потенциал саморазвивающейся нормативной культуры современного общества, не «просмотреть» эту самобытную культуру коллективного творчества и «реанимировать» традиционные источники права, такие как обычаи, международные и деловые обыкновения, своды единообразных правил, нормы корпораций, общественных объединений? Думается, что фактическое признание их регулирующего воздействия и самоценности должно превратиться в факт современной реальности, требующий официального признания и отражения в правовой политике.

20 См.: А. А. Соколова, Законодательный процесс: основные понятия и институты: Учеб.-метод. пособие, Минск 2003, с. 22.

21 Конституция Республики Беларусь 1994 года, http://pravo.by/pravovaya-informatsiya/ normativnye-dokumenty/konstitutsiya-respubliki-belarus/ (дата обращения: 20.01.2019). 


\section{Искусственный интеллект в юриспруденции как вызов законодательной политике}

Один из основных вызовов XXI века - развитие современных технологий. Создание искусственного интеллекта поставило новые проблемы перед человечеством, в том числе перед юридическим миром как весьма значимой частью его бытия. Как следует относиться к новым технологиям и внедрению искусственного интеллекта в юриспруденцию? Приведет ли этот процесс к конкуренции на рынке труда и замене некоторых категорий юридической профессии юристами-роботами, как оценить возможные риски применения искусственного интеллекта в юридической сфере? Проблема активно обсуждается в юридическом сообществе: палитра мнений расходится от консервативного отношения к технологическим новациям до достаточно взвешенного восприятия и предвидения положительных эффектов в использовании искусственного интеллекта в юридической практике. В социальной сети бытует мнение о том, что в настоящее время уже происходит LegalTech-революция 22 . Разумный научный оптимизм позволяет нам воспринимать ее как современное достижение в юриспруденции, задающее новый вектор ее модернизации и придающее новый смысл правовой/законотворческой политике.

В законопроектной деятельности искусственный интеллект можно использовать как инструмент юридической техники, обеспечивающий автоматизацию и компьютеризацию действий по обработке социологических и статистических данных, проведению количественного анализа, математических способов прогнозирования последствий правовых актов. А в содержательном процессе разработки законопроектов? Думается, что если соотнести процесс создания искусственного интеллекта и процесс формирования права, то, по сути, создание права - это информационная технология, алгоритм особых операций, которые может обеспечить искусственный интеллект. И простые, с позиции юридической техники, не требующие сложной правовой аргументации и обоснования проекты норм права, могут, на мой взгляд, готовить компьютеры и тем самым освобождать специалистов от технического труда. Более категоричен в своей позиции профессор И. Н. Глебов, который настроен оптимистично к признанию позиции робота-законодателя, способного «без участия человеческих порочных факторов создавать безупречные законы и исправлять ошибочные» 23 .

22 Там же, с. 25.

23 Конституция (Основной Закон) СССР. Принята на внеочередной седьмой сессии Верховного Совета СССР девятого созыва 7 октября 1977 г., http://www.hist.msu.ru/ ER/Etext/cnst1977.htm (дата обращения: 20.01.2019). 
Другая сторона создания права, не подвластная искусственному интеллекту в ближайшем будущем, но допускающая его активное «соучастие» с интеллектом естественным, - исследовательская, аналитическая, творческая, требующая социолого-правового сопровождения, интеллектуальных междисциплинарных усилий профессионалов, их высокого мастерства и профессионализма. В этой части законотворчества, на мой взгляд, естественный интеллект «непобедим»!

Следует признать прогностический, вероятностный характер рассуждений этого фрагмента, однако, в определении стратегических направлений в правовой/законодательной политике, ее модернизации учет новаций LegalTech-революции объективно необходим.

\section{Выводы}

Социальный мир в XXI веке кардинально изменился: вызовы глобального мира поставили новые проблемы перед человечеством, многие из которых могут быть преодолены правовым инструментарием. В данном исследовании сделана попытка представить путь модернизации правовой/законодательной политики в новых смысловых значениях и сделать акценты на проблемных вопросах, требующих глубокого изучения и осмысления.

Резюмирующий вывод заключается в идее частичного «разгосударствления» законопроектной деятельности, включения в процесс разработки и обсуждения проектов правовых актов социальных институтов. Социальное партнерство государства и общества в этом процессе необходимо. Безусловно, это долгий путь трансформации идеологии отношения к роли государства - от доминирующей и самодостаточной до организующей и содействующей развитию гражданского общества.

Включение в правовую политику задачи «разгосударствления» законопроектной деятельности, мультипликации субъектов правотворчества направлено не на замену государственного права негосударственным, а на взаимопроникновение правового и неправового механизмов правового регулирования, правовое взаимодействие всех «творческих» сил общества в сфере публичного пространства. Чем демократичнее государство, чем более развито гражданское общество, тем ответственнее все его социальные институты за направленность правовой политики, уровень правовой системы и правопорядка.

Сопричастность акторов гражданского общества процессу формирования права - объективное требование качества законодательной деятельности, индикатор/показатель культуры законотворчества. Попытка реконструиро- 
вать правовую политику, включив в нее реальные элементы демократической культуры оправданны. Основной вопрос заключается в следующем: готовы ли граждане участвовать в таких проектах, и главное: готово ли государство «поделиться» приоритетной ролью законотворца и доверить законодательную политику своим гражданам.

\section{Резюмe}

Предлагаемая статья посвящена анализу общетеоретических проблем правовой (законодательной) политики, которая становится определяющей категорией юридической науки XXI века. Обращение к этой теме вызвано затянувшимся в постсоветских государствах процессом трансформации и недостаточной эффективностью экономических и социальных преобразований. По-прежнему актуальными остаются проблемы научной и социальной обеспеченности, демократизации законодательного процесса, эффективности его результатов. В чем истоки столь инертного процесса модернизации законотворчества? Попытка осмыслить эту ситуацию и раскрыть новые смыслы законодательной политики в XXI веке предлагается в данной статье.

\section{Alla Sokolova}

\section{New Meanings of Legal Policy: Contemporary Challenges and Prospects}

The suggested article is dedicated to the analysis of general theoretical problems of legal (legislative) policy, which becomes a defining category of the legal science of the $21^{\text {st }}$ century. Appeal to this topic is caused by protracted transformation in post-Soviet states and insufficient effectiveness of economic and social changes. The issues of scientific and social security, democratization of the legislative process and effectiveness of its results remain important. What are the origins of such an inert process of modernization of lawmaking? An attempt to comprehend this situation and find new meaning in legislative policy in the $21^{\text {st }}$ century is made in this article.

KEY WORDS: legal/lawmaking policy, social nature of lawmaking, public sphere, multiplications of lawmaking subjects, artificial intelligence 


\section{Библиография}

J.-L. Bergel, General Theory of Law, Moscow 2000.

P. Bourdieu, Social Space: Fields and Practices, St. Petersburg 2005.

I. N. Glebov, Artificial Legal Intelligence, Network Scientific Law Journal «Humanitarian Law» 2018, https://humanlaw.ru/9-article/26-artificial-intelligence.html (дата обращения: 20.01.2019).

V. G. Grafskiy, Legal Communication in the Past and the Present, «Law and Politics» 2011, No. 1.

I. A. Kulazhnikov, Social legal policy of the Russian state. Author. dis. cand. legal sciences, Rostov-on-Don, 2005.

B. Leoni, Freedom and the Law, Moscow 2008.

R. Z. Livshits, State and Law in Modern Society: the Need for New Approaches, «The Soviet State and Law»1990, No. 10.

A. V. Malko, Theory of Legal Policy: Monograph, Moscow 2012.

A. V. Malko, Legal Policy of Modern Society: From Theory to Practice, «Newsletter of the Mariupol State University. Serya: Law» 2012, Issue. 3-4.

L. S. Mamut, Legal Intercourse. Essay of Theory, Moscow 2011.

N. I. Matuzov, A. V. Malko (eds.), Legal policy: Theory and Practice: Monograph, Moscow 2006.

A. V. Polyakov, The Rule of Law, Globalization and Problems of Modernization of Philosophy and Theory of Law, «Jurisprudence» 2013, No. 4 (309).

A. A. Sokolova, Legislative process: basic concepts and institutions: Manual, Minsk 2003.

A. A. Sokolova, Social Aspects of the Lawmaking, Minsk 2003.

A. A. Sokolova, Legal policy in the public dimension: directions of development [in:] V. V. Smirnov (ed.), Collection of materials of the All-Russian conference "Legal Policy in the Conditions of Modernization” November 19, 2010, Moscow 2011.

A. A. Sokolova, Democratic Culture in Legislative Activity: the Practice of Crowdsourcing, [in:] Legal Technique: Legislative, Interpretative, Law Enforcement Technique in the Context of Culture and Intercultural Communication, Nizhny Novgorod, Yearbook, 2016, No. 10.

A. A. Sokolova, Personality, Society, State: Problems of Legal communication, [in:] V. S. Nersesyants. V. G. Grafskiy (eds.), The modern state and personality in historical and philosophical and legal understanding: a collection of materials of the twelfth philosophical and legal readings in memory of academician Moscow, Norma, 2018.

I. Tsvetkova, Artificial Intelligence in Court, Lawyers bots and Crowdfunding of Legal Disputes - how the LegalTech-revolution begins. 2017, https://rb.ru/opinion/legaltech/ (дата обращения: 20.01.2019). 
Вениамин Евгеньевич Чиркин

ORCID: 0000-0002-6471-9212

\section{Современные федерации}

и основные конституционные признаки федеративного государства

КЛЮЧЕВЫЕ СЛОВА:

современные федерации, основные признаки федерации, существенные особенности некоторых федераций

В настоящее время в мире существует 31 федеративное государство. После второй мировой войны их численность выросла в три раза. Кроме того, в государствах тоталитарного социализма (СССР, Чехословакия, Югославия), в Индонезии, на Ближнем Востоке, в других странах также существовали федерации (иногда длительное время), которых теперь нет. Тренд к федерализму, иногда проистекающий из убеждения, особенно развивавшегося в американской литературе, что федерация более демократическая форма государственно-территориального устройства (что не всегда так), обусловил появление некоторых новых моделей федерализма в специфических условиях некоторых стран (например, в Бельгии или в Мьянме).

Новые федерации побуждают оценить, насколько выделенные ранее в науке индикаторы федерализма соответствуют современности и выяснить каковы теперь общие признаки федерализма (если такие есть), которые могут быть применены ко всем современным федерациям, несмотря на существенные особенности некоторых из них. При этом мы рассматриваем федерацию только как особую форму государственно-территориального устройства, анализируя ее юридическое содержание и не оценивая ее социальную сущность (ясно, что по социальной сущности федерация в тоталитарно-социалистическом СССР и либерально-капиталистической Германии, например в 50-90-х гг. XX в. были принципиально разными федеративными государствами). Отметим также, что в статье речь идет о федера- 
тивных государствах, а не вообще о публично-правовых федерациях разного рода, которым иногда посвящены очень интересные зарубежные работы.

В научной литературе существует огромное число работ на многих языках стран мира, посвященных вопросам государственного федерализма. В них почти всегда называют те или иные признаки федерализма. По многим позициям мнения ученых совпадают (например, что территория федерации государственно едина, но состоит из территориальных единиц с особым правовым статусом, подобного которому нет в унитарных или региональных государствах). В ст. 5 и других статьях Конституции РФ 1993 г. они обобщенно названы «субъектами федерации» ${ }^{1}$; в зарубежной литературе обобщенного названия нет. В них территориальные публично-правовые образования, являющиеся составными частями федерации, называют по-разному - штаты, земли, провинции и др. Обычно в зарубежных федерациях используется один вид и одно название таких частей (в Мьянме - два).

Мнения ученых об общих признаках федерации совпадают в вопросе о верховенстве федерального права, по вопросу о возможности применения федерального принуждения, если субъект федерации нарушает федеральную конституцию и некоторым другим вопросам, но по другим позициям часто расходятся.

Длительное время признаки федерации, как особой формы государственно-территориального устройства (независимо от ее социального характера в разных странах), формулировались на опыте федеративных государств, существовавших до распада колониальной системы (четыре государства в Европе, включая СССР², Чехословакию и Югославию, и шесть в Латинской и Северной Америке, включая Канаду и США). В настоящее время, если судить по определениям и нормам конституций (в реальной жизни некоторых стран Азии и Африки дело обстоит не совсем так), шесть федераций существуют в Европе - Россия, Австрия, Бельгия, Босния и Герцеговина (по порядку формирования органов государства и разграничению полномочий она, скорее, конфедерация, внутри нее есть два субъекта федерации, и один из них тоже федерация и с таким же названием - хорватобоснийская Федерация Боснии и Герцеговины, другой субъект - Республика

1 Правда, на наш взгляд, в этой же статье (ч. 4 ст. 5) часть разновидностей субъектов Российской Федерации (22 республики в составе РФ) неверно названы государствами. На территории России одно государство - РФ.

2 РСФСР в составе СССР считалась федерацией на основе автономии (другие - на иной основе, но не говорилось - какой?). Только в отношении СССР прямо говорилось, что 15 союзных республик - суверенные государства. В зарубежных странах характер власти в составных территориальных публично-правовых образованиях федераций до сих пор не определен. При обобщениях признаков федерации РСФСР обычно не учитывалась. 
Сербская), Германия, Швейцария; семь в Азии - Индия, Малайзия, Непал, ОАЭ, Пакистан, Ирак, Союз Мьянмы; семь в Америке - Аргентина, Бразилия, Венесуэла, Канада, Мексика, США, Сент-Кристофер (Сен-Китс) и Невис; семь в Африке -Коморские острова, Нигерия, Республика Южный Судан (с 2013 г.; есть и другой Судан, тоже провозглашенный ранее федерацией), Сомали, Танзания, Эфиопия; три в Океании - Австралия, Папуа Новая Гвинея (отнесение этой страны к федерациям спорно), Соединенные Штаты Микронезии.

Структура новых федераций в странах Азии, Африки, Америки (Сен-Китс и Невис), Океании, их организация, с одной стороны, подтверждают некоторые ранее выделенные признаки федерализма, а с другой стороны, вносят в них коррективы, осложняют выделение общих для всех стран индикаторов федеративного государства. Осложняют такое выделение и особенности европейских федераций Бельгии и Боснии и Герцеговины. По-разному оценивают территориальное устройство Папуа - Новой Гвинеи и Танзании (в последней стране в 2016 г. готовились вынести на референдум новую конституцию, которая предусматривала реформирование государственнотерриториального устройства и принятие традиционных признаков федерализма, но референдум был отложен и до сих пор не состоялся).

Осложняет ситуацию правовое положение ЮАР. По конституции ЮАР 1996 г. государство нигде не названо федерацией. Между тем, положение территориальных частей таково (10 провинций, одна их них названа штатом;свои конституции; право собственного законодательства; в парламенте есть особая палата для представительства провинций; разграничение полномочий между государством и провинциями и др.), что это по существу делает ЮАР такой формой государственно-территориального устройства, которая ближе к федеративному государству. Отсюда возникает проблема промежуточных или смешанных форм регионального ${ }^{3}$ и федеративного государства.

Проблемы научных классификаций возникают иногда также с Италией и Испанией. Некоторые зарубежные авторы считают их федерациями. Правда, в отношении Италии отрицательный ответ был выражен официально, когда в 2012 г. избиратели отвергли на референдуме принятую парламентом поправку к Конституции 1947 г., предусматривавшую создание в стране федерации.

Поэтому, выделяя признаки федерализма, необходимо сначала определить некоторые общие позиции, с которых мы будем вычленять эти признаки.

3 По примеру некоторых других исследователей мы называем региональным государством такое, которое целиком состоит не из административно-территориальных единиц и не из субъектов федерации, а из территориальных автономных образований. 
Во-первых, вряд ли для нашей цели нужно разделять признаки федеративного государства на основные и факультативные. Факультативные - это особенности отдельных федераций. Нам важно выяснить не просто те или иные свойства федераций, которые могут быть, а могут не быть, а общие основные признаки федеративного государства, присущие всем современным федерациям. Установить их в конституционном измерении с учетом не только формального определения в конституциях данной формы государственно-территориального устройства, но и других конституционных положений, а также существующих реалий. С другой стороны, вряд ли следует называть десятки признаков ${ }^{4}$. Это, по существу, снимает саму проблему об основных признаках.

Во-вторых, при выявлении таких общих признаков, мы не учитываем федерации и квазифедерации в зависимых странах (например, федерацию Нидерландских Антильских островов), а также федерации и квазифедерации прошлого (в том числе далекого). Мы выделяем признаки современного федеративного государства.

В-третьих, нужно иметь в виду, что в юридических, государствоведческих и политологических исследованиях, могут применяться разные подходы к определению, является или нет то или иное государство федерацией. Хотя, как говорилось, мы отвлекаемся от социальных оценок, но в условиях тоталитарных режимов некоторые государства, называемые в конституциях федерациями (с определенной правовой самостоятельностью их составных частей на уровне федерализма) по существу, превращаются в унитарные государства. Напротив, отдельные государства, не названные в конституциях федерациями, имеют многие основные признаки последних (выше говорилось о ЮАР). Поэтому, выделяя конституционные признаки федерализма, мы учитываем не только правовые нормы, но и фактическое положение.

Конечно, при отнесении государства к федерациям (или, напротив, при исключении из этой группы) было бы проще всего ориентироваться на формальный признак, который был бы единственным, - определение в конституции. Если в конституции сказано, что государство федеративное, то оно признается, в том числе в науке, федерацией. Игнорировать такое определение невозможно. Нельзя назвать с юридических позиций государство не федерацией, если его конституция утверждает, что это федерация. Такого в юридической науке нет, хотя с позиций фактического анализа понятие федерации отвергалось по отношению к названным выше социалистическим государствам. На деле, они были федерациями, но федерациями тоталитарного социализма. Формально-юридические признаки федерализма они имели.

4 М. В. Глигич-Золотарева, Правовые основы федерализма, Москва 2006. 
Исследователи федерализма учитывают не только слово, а прежде всего положения конституции, которые присущи федеративному государству. В этом юридический подход при исследовании федерализма в какой-то мере отличается от государствоведческого и политологического. Фактическое положение в юридических исследованиях тоже учитывается, но на первый план в юридическом подходе выдвигаются конституционные нормы, регулирующие отношения государства и его составных территориально-правовых частей. Если же на практике основные признаки федеративного государства упразднены, то в данном случае при сохранении юридического определения «федерация» речь пойдет уже о государственном режиме и иных обстоятельствах фактического и правового порядка.

После анализа терминологии и конституционно-правовых отношений для установления реального состояния государственно-территориального устройства без государствоведческого подхода не обойтись. Сомали в Африке в 2012 г. провозглашена федеративным государством, но на деле в стране до сих пор несколько самопровозглашенных государств, враждующих между собой, в том числе, с использованием вооруженных сил. И, напротив, как говорилось, в Конституции ЮАР 1996 г. нет слова «федерация» (да и в самой ЮАР возражают против отнесения страны к федерации), но, на деле, в Конституции обозначены все основные признаки федеративного государства, о которых говорится ниже. С позиций государствоведения мы можем назвать ее фактически федеративным государством, но с позиций юридического исследования не можем сказать, что ЮАР - федерация, заметив, что она имеет многие основные признаки федеративного государства.

Несмотря на многие особенности современных федераций, обобщение положений конституций федеративных государств мира и имеющихся исследований, на наш взгляд, позволяет выделить некоторые общие основные конституционные признаки современного федеративного государства.

Во-первых, это суверенное союзное государство, только оно имеет государственный суверенитет в территориальной структуре федерации. Элемент «союзности» выражен во многих положениях конституции (в названиях («соединенное», «союзное» и др., в объединительных процессах создания многих федераций, в равноправии субъектов федерации, разграничении полномочий и др.). Во многих странах в названии государства используется слово «федерация», что происходит от латинского слова foedus, обозначающего «союз», «объединение»; в других принято название «соединенные штаты», «объединенная республика» (кстати, по-английски это одно и то же слово - united); в третьих - слово «союз» (Мьянма, Индия). В названиях некоторых федераций такого слова нет, но оно есть в тексте конституций (Бельгия, Ирак). Термины «федерация», «союз» присутствуют и в тех 
странах, где федерация учреждена «сверху», актом государственной власти, а не возникла в результате объединения государств (например, Танзания) или других территориальных единиц. В ней всегда есть элемент союза различных территориальных публично-правовых образований (субъектов федерации), населяющих их народов (при многоэтническом, разном языковом составе общества, если федерация или некоторые ее части созданы на основе учета этнических или языковых данных, например, в Бельгии, Индии, Ираке, Эфиопии).

Разумеется, как и во всяком сообществе, в федерации существуют также элементы состязательности (противоречия и борьба, но ведущим, пока федерация существует, является состояние союза. Союз (основное) и борьба (частное), существующие, определяют в рамках правового поля развитие федерации.

Во-вторых, территория федеративного государства состоит не из административно-территориальных единиц или территориальных автономий, а из особых юридически равноправных (независимо от размеров территории и численности населения) территориальных публично-правовых образований - субъектов федерации. Разница в их физических показателях в разных государствах и в одном и том же государстве может быть очень большой. Например, население (около 10 тыс. человек) одного из двух субъектов федерации Сент-Кристофер и Науру небольшого островка Науру (в диаметре около 8 км), в тысячу раз меньше наиболее крупных штатов Индии. В России по территории субъекты РФ различаются в 388 раз (Якутия (Саха) и Северная Осетия - Алания) и, исключая субъект РФ - Москву, в 190 раз по населению (Московская область и Ненецкий автономный округ), что, вообще говоря, не очень хорошо. Однако все они имеют одинаковый правовой статус субъекта федерации, иной, чем статус самого крупного территориального автономного образования или самого крупного муниципального образования (хотя есть такие автономии и даже муниципальные образования, которые намного крупнее по территории и населению некоторых субъектов федераций).

В-третьих, федерация имеет разновидности публичной власти государственного характера: суверенную государственную власть федерации и государствоподобную власть субъектов федерации и соответственно две системы таких органов 5 . В настоящее время субъекты федерации нигде, кроме республик в составе России (по Конституции 1993 г.) и штатов в Венесуэле (по

5 В муниципальных образованиях есть третья - муниципальная публичная власть с ее органами, но она не имеет отношения к основным признакам федеративного государства. 
Конституции 1999 г.) не называют государствами ${ }^{6}$. Конечно, в некоторых странах название субъектов федерации на их языках может быть понято как государство (state - англ., estado - исп., хотя эти слова имеют и другой перевод на русский язык). На деле в США, Германии, Индии, Нигерии, Аргентине, Бразилии, Мексике и других странах субъекты федераций не считают государствами. Уже давно хорошо образованные русские юристы не стали использовать для них термин «государство», а применили неологизм - штат.

На деле, на территории федеративного государства, кроме федеральной государственной власти, других государственных властей быть не может, принцип государственного суверенитета федеративного государства это исключает.

В-четвертых, в федерации действуют принципы верховенства федеральной публичной (т.е. государственной) власти и федерального права. Свое наиболее острое применение они находят при использовании федерацией федерального принуждения вплоть до военного при наиболее грубых нарушениях федеральной конституции (было в США, Швейцарии, России, Нигерии). Возможность федерального принуждения - производный признак указанного верховенства.

В-пятых, существует конституционное разграничение предметов ведения и полномочий федерации и предметов ведения и полномочий ее субъектов, причем есть и особая группа совместных полномочий (для территориальных автономий и, тем более, муниципальных образований такого разграничения нет, существует выделение им определенных полномочий законом). Разграничение осуществляется по-разному (мы называем в учебниках по конституционному праву пять таких способов), но в данном случае нет необходимости рассматривать их, важно констатировать сам факт, как общий конституционный признак федеративного государства.

В-шестых, в федерациях существуют особые организационные формы и правовые институты, предназначенные для выражения специфических интересов субъектов федерации и участия их в решении вопросов федерального значения. Их не следует сводить только к особой палате в федеральном парламенте, а эту палату толковать только как орган представительства специфических интересов. Палата действует также как орган участия субъектов федерации в решении общих вопросов. Имеются и другие формы, хотя они редко упоминаются в конституциях: особые должности министров для субъектов федерации, представительства субъектов федерации при правительстве, отказ от обсуждения проекта федерального закона или от его принятия,

6 На наш взгляд, положения ч. 2 ст. 5 Конституции РФ неверны. Вряд ли можно считать, что на территории России существует 23 государства (22 республики в составе РФ и сама федерация). 
если он вызывает возражения у определенного числа субъектов федерации, участие субъектов федерации в обсуждении проектов международных договоров, если они затрагивают их интересы, и др. В Танзании особой палаты для представительства двух субъектов объединенной республики (Танзании и Занзибара) нет, но существует установленное привилегированное представительство Занзибара в однопалатном парламенте государства, которое намного превышает его долю в населении страны.

Этим, на наш взгляд, исчерпываются основные общие конституционные признаки современного федеративного государства. Что же касается иных признаков, иногда называемых в литературе, то они могут быть, а могут и не быть. Так, во многих федерациях их субъекты имеют свои конституции, но в России меньшая часть субъектов РФ имеет конституции (22 республики в составе РФ), а большая часть (63 субъекта РФ) имеет уставы. У бельгийских регионов, у индийских штатов конституций нет (кроме отчасти подобного документа для штата Джамму и Кашмир), но, напротив, некоторые территориальные автономии их имеют (Каракалпакия в Узбекистане и Нахичевань в Азербайджане). Право принимать свои законы имеют и некоторые территориальные автономные образования (например, Шотландия в Великобритании).

Собственное гражданство субъекты федераций имеют редко, в большинстве стран его нет, а в Соединенных Штатах оно практического значения почти не имеет. Своя целостная система судов у субъектов федераций тоже редкость. По существу, в завершенном виде она есть только в США. Добровольность объединения при создании федерации тоже бывает не всегда. Федерации в Индии, Нигерии, Пакистане, Малайзии и некоторых других странах, созданы сверху актами государственной власти. Соглашения о создании государства Боснии и Герцеговины были подписаны в далекой Америке, в Вашингтоне и на американской военной базе в Дейтоне (США), в 1995 г. Да и предпосылки германской федерации создавал еще Бисмарк «железом»и кровью.

Можно привести другие данные, которые противоречат называемым в литературе общим признакам федерализма. Но и намеченные выше шесть общих конституционных признаков федеративного государства тоже не являются истиной в последней инстанции. Возникают новые явления, которые требуют постоянных уточнений. 


\section{РЕЗЮME}

В статье рассматриваются традиционные модели федеративных государств и появление новых федераций после второй мировой войны. Сделана попытка выявить основные признаки федеративного государства в современных условиях с учетом новых моделей федерализма, возникших после распада колониальной системы. Автор оценивает, насколько прежние признаки федерализма соответствуют современным условиям. В статье отмечаются особенности некоторых новых федераций (сказано только о существенных особенностях), но автор полагает, что выделенные общие признаки относятся ко всем федерациям, несмотря на своеобразие некоторых из них.

\section{Veniamin E. Chirkin}

\section{Modern Federations and Main Constitutional Signs of the Federal State}

This article discusses traditional models of federated states and the emergence of new federations after the second world war. An attempt was made to identify key signs of a federal state in modern conditions, taking into consideration new models of federalism, arising after the collapse of the colonial system. The author evaluates the extent to which previous signs of federalism correspond to modern conditions. The article highlights some of the features of the new federations (told only on significant features), but the author believes that selected common signs refer to all federations, despite the originality of some of them.

KEY WORDs: modern federations, basic signs of the federation, essential features of some federations

\section{Библиография}

M. V. Gligich-Zolotareva, Legal Basis of Federalism, Moscow 2006. 


\title{
Конституционные преобразования в странах СНГ и Западной Европы: эволюционная необходимость или ответ современным вызовам
}

\author{
КЛЮЧЕВЫЕ СЛОВА: \\ конституция, конституционное развитие, конституциионная реформа, \\ современные вызовы, зарубежсные страны
}

Практика зарубежных стран последних лет подтверждает тезис о динамичности конституционных преобразований на современном этапе. Несмотря на неодинаковую степень интенсивности и объем проведения конституционных реформ в различных странах мира, следует отметить их общую черту они выступают конституционным модератором, конституционным ответом на внешние и внутренние вызовы для государства. Безусловно, многие конституционные реформы обусловлены внешними вызовами и угрозами, к числу наиболее значительных относится, по нашему мнению, угроза терроризма и как следствие - все более отчетливо проявляющийся кризис безопасности, реакцией на который выступают в том числе конституционные преобразования. Вместе с тем, внутренние вызовы современного государства также являются причинами конституционных изменений. Отметим, что в странах СНГ, особенно в его азиатской части, и государствах Западной Европы наблюдаются различные направления проводимых конституционных реформ.

Анализ практики конституционного реформирования имеет огромное значение для Республики Беларусь, поскольку позволяет выделить основные направления конституционных изменений, происходящих в мире, соотнести их с белорусской действительностью и спрогнозировать дальнейшие возможные направления конституционного развития Республики Беларусь. 
Одним из направлений конституционных реформ на постсоветском пространстве выступает изменение типа существующей республиканской формы правления (Армения, Кыргызстан, Казахстан и др.), и, как следствие, - перераспределение компетенции между высшими государственными органами, а также конституционализация статуса высших должностных лиц государства, прежде всего, Первого Президента Республики (Казахстан, Таджикистан).

Опыт конституционного развития государств постсоветской эпохи отличается определенным динамизмом. Одна из причин достаточно легкого перекраивания конституций состоит в особенностях политической системы, сложившихся в этих странах.

Конституционные положения о структуре власти, системе государственных органов, их взаимоотношениях обусловлены общим концептуальным подходом к типу политической системы в конкретной стране 1 . Весьма интересен в данном контексте конституционно-правовой опыт таких государств как Республика Казахстан, Республика Таджикистан, Республика Армения, Республики Азербайджан, Кыргызской Республики.

18 мая 2007 года парламент Казахстана одобрил поправки к Конституции 1995 г. с изменениями и дополнениями от 1998 г. о снижении срока полномочий Президента с 7 лет до 5 лет (срок полномочий был увеличен конституционной реформой 1998 года), а также установил ограничения для переизбрания президента двумя сроками. Однако для Н. Назарбаева как первого президента Казахстана было сделано исключение - он может баллотироваться неограниченное количество раз. В соответствии с п. 5 ст. 42 Конституции: «Одно и то же лицо не может быть избрано Президентом Республики более двух раз подряд. Настоящее ограничение не распространяется на Первого Президента Республики Казахстан»².

Конституционным законом Республики Казахстан «О Первом Президенте Республики Казахстан - Лидере Нации» определяется политико-правовой статус Первого Президента Республики Казахстан как Лидера Нации, а также прерогативы и гарантии Первого Президента Республики Казахстан после прекращения им исполнения полномочий${ }^{3}$. Первому Президенту Республики Казахстан - Лидеру Нации в силу его исторической миссии пожизненно при-

1 Р. В. Енгибарян, Конституционное развитие в современном мире, Москва 2010, с. 237.

2 Конституция Республики Казахстан принята на референдуме 30 августа 1995 года (внесены изменения и дополнения 7 октября 1998 года, 21 мая 2007 года, 2 февраля 2011 года), http://www.akorda.kz/ru/official_documents/constitution (дата обращения: 18.03.2018).

3 Конституционный закон Республики Казахстан «О Первом Президенте Республики Казахстан - Лидере Нации» от 20 июля 2000 года N 83-II, http://www.akorda.kz/ru/ official_documents/constitution (дата обращения: 18.03.2018). 
надлежит право: обращаться к народу Казахстана, государственным органам и должностным лицам с инициативами по важнейшим вопросам государственного строительства, внутренней и внешней политики и безопасности страны, которые подлежат обязательному рассмотрению соответствующими государственными органами и должностными лицами; выступать перед Парламентом Республики Казахстан и его Палатами, на заседаниях Правительства Республики при обсуждении важных для страны вопросов; возглавлять Ассамблею народа Казахстана; входить в состав Конституционного Совета, Совета Безопасности Республики Казахстан. Разрабатываемые инициативы по основным направлениям внутренней и внешней политики государства согласовываются с Первым Президентом Республики Казахстан - Лидером Нации.

В феврале 2011 года в Конституцию Казахстана вновь внесены изменения. Статья 41 Конституции дополнена пунктом 3-1 следующего содержания: «Внеочередные президентские выборы назначаются решением Президента Республики и проводятся в порядке и сроки, установленные конституционным законом» 4 . Таким образом, действующий президент сам решает вопрос о проведении досрочных президентских выборов.

Весной 2017 г. в Республике Казахстан прошел очередной этап конституционной реформы, инициированной Президентом. 11 января 2017 г. Президентом Казахстана было подписано распоряжение об образовании Рабочей группы по вопросам перераспределения полномочий между ветвями государственной власти.

Законом Республики Казахстан от 10 марта 2017 года № 51-VI «O внесении изменений и дополнений в Конституцию Республики Казахстан» в Конституцию Казахстана 1995 г. были внесены принципиально новые положения.

В частности, конституционной реакцией на угрозу терроризма в ст. 10 включено положение, предусматривающее, что лишение гражданства допускается лишь по решению суда за совершение террористических преступлений, а также за причинение иного тяжкого вреда жизненно важным интересам Республики Казахстан.

В целях усиления конституционных гарантий единства народа Казахстана внесено изменение в пункт 2 статьи 39 Конституции, согласно которому признаются неконституционными любые действия, способные нарушить не только межнациональное, но и межконфессиональное согласие.

4 Закон Республики Казахстан «О внесении дополнения в Конституцию Республики Казахстан» от 2 февраля 2011 года № 403-IV, http://www.akorda.kz/ru/official_ documents/constitution (дата обращения: 18.03.2018). 
Законом осуществлена демократическая модернизация президентской формы правления посредством усиления роли, самостоятельности и ответственности Парламента и Правительства, перераспределения отдельных полномочий между Президентом, Парламентом и Правительством, исходя из принципа единства и разделенности государственной власти. Так, изменяются конституционные характеристики Парламента, отныне он является высшим представительным органом Республики, осуществляющим законодательную власть. Данное принципиальное уточнение предназначения Парламента вытекает из отказа Главы государства от полномочий по изданию законов, указов, имеющих силу законов; по осуществлению законодательных полномочий в случае делегирования их ему Парламентом, а также по даче поручения Правительству о внесении законопроекта в Мажилис Парламента (пункт 2 статьи 45, пункт 2 статьи 61 Конституции, подпункт 3 статьи 44 Конституции). В то же время за Президентом Республики сохраняется право законодательной инициативы и право определять приоритетность рассмотрения законопроектов, означающее, что они должны быть приняты Парламентом в первоочередном порядке в течение двух месяцев (пункт 2 статьи 61 Конституции).

Отныне к исключительному ведению Сената Парламента отнесено избрание по представлению Президента Республики на должность сроком на пять лет и освобождение от должности Уполномоченного по правам человека в Республике Казахстан.

Повышается роль Мажилиса Парламента при формировании Правительства. Учрежден новый порядок формирования Правительства: ПремьерМинистр после консультаций с Мажилисом Парламента вносит представление Главе государства о кандидатурах членов Правительства. Исключение предусматривается для должностей министров иностранных дел, обороны и внутренних дел, которые назначаются и освобождаются Президентом самостоятельно (пп. 3 статьи 44 Конституции).

Принципиально новой выступает норма, устанавливающая сложение Правительством своих полномочий перед вновь избранным Мажилисом Парламента (п. 1 статьи 70 Конституции).

Наблюдается усиление механизмов подотчетности и подконтрольности Правительства Парламенту и его палатам. В частности, в пункте 2 статьи 64 Конституции устанавливается, что Правительство в своей деятельности ответственно как перед Президентом, так и Парламентом; на ПремьерМинистра возлагается обязанность докладывать об основных направлениях деятельности Правительства и о всех его важнейших решениях не только Президенту, но и Парламенту; Палаты Парламента наделяются правом по итогам заслушивания отчета члена Правительства большинством не менее 
чем двумя третями голосов от общего числа депутатов Палаты принимать обращение к Президенту Республики об освобождении от должности члена Правительства при неисполнении им законов. В таком случае Глава государства освобождает от должности члена Правительства.

Повышению самостоятельности и ответственности Правительства служит также ряд изменений, касающихся конституционного статуса Главы государства, его полномочий. Расширены квалификационные требования к кандидатам в Президенты Республики (в частности, предусмотрено наличие высшего образования).

От Президента Республики Правительству переданы следующие полномочия: утверждение государственных программ и единой системы финансирования и оплаты труда работников для всех органов, содержащихся за счет государственного бюджета, которые будут осуществляться Правительством по согласованию с Главой государства. Президент Республики наделен правом формирования подчиненной ему Службы государственной охраны. Кроме того, Президент Казахстана утратил право отменять либо приостанавливать действие актов Правительства и Премьер-Министра, отныне он может председательствовать на заседаниях Правительства по особо важным вопросам только «при необходимости».

От Президента Республики передано Парламенту полномочие по определению порядка назначения или избрания на должность, а также освобождения от должности акимов иных, кроме областей, городов республиканского значения и столицы, административно-территориальных единиц. Полномочия маслихата прекращаются досрочно Президентом Республики после консультаций с Премьер-Министром и председателями Палат Парламента.

Вместе с тем, сохраняется ряд функций Президента Республики как высшего должностного лица государства, определяющего основные направления внутренней и внешней политики государства, представляющего Казахстан внутри страны и в международных отношениях; символа и гаранта единства народа и государственной власти, незыблемости Конституции, прав и свобод человека и гражданина; Главы государства, обеспечивающего согласованное функционирование всех ветвей государственной власти и ответственность органов власти перед народом (статья 40 Конституции).

Республика Таджикистан приняла постсоциалистическую Конституцию 6 ноября 1994 г. Статья 98 Конституции закрепляет: «Изменения и дополнения в Конституцию вносятся путем проведения всенародного референдума. Референдум назначают Президент или Маджлиси намояндагон при поддержке не менее двух третей от общего числа депутатов». Предложения по изменению и дополнению в Конституцию вносятся Президентом или не менее чем одной третью голосов от общего числа членов верхней и депу- 
татов нижней палаты парламента (ст. 99 Конституции)5. Предложения по изменению и дополнению Конституции публикуются в печати за три месяца до референдума. Изменения вносились в 1999 г. и касались установления двухпалатной структуры парламента вместо однопалатного, в 2003 г. увеличен срок полномочий президента с пяти до семи лет.

25 декабря 2015 г. Президент Таджикистана подписал Закон «Об основоположнике мира и согласия - Лидере нации». Данный законопроект 9 декабря 2015 г. был единогласно одобрен нижней палатой и 18 декабря верхней палатой парламента. Закон определяет роль главы государства как основателя мира и национального единства, символа долговечности таджикской суверенной государственности. Таким образом, он пожизненно объявлен Лидером Нации Таджикистана.

Закон определяет права и привилегии, в том числе и социальные гарантии Лидера нации, вопросы обеспечения безопасности. Согласно статье 2 Закона, Лидера нации запрещено задерживать, арестовывать и обыскивать. Также подлежат неприкосновенности имущество, недвижимость, принадлежащие Лидеру нации и его близким. В соответствии с Законом исполнение всех рекомендаций Лидера нации станет обязательным для всех государственных структур, а «важные политические внутренние и зарубежные проблемы» будут решаться по согласованию с ним. За все действия, совершенные за годы правления страной, Лидеру нации гарантируется неприкосновенность. В Таджикистане к президенту Эмомали Рахмону установлена особая форма обращения «Чаноби Оли», что в переводе означает «Ваше Превосходительство». Теперь к общепринятому обращению официально добавляется титул «пешвои миллат», что в переводе с таджикского означает «предводитель (или лидер) нации». Обращение к президенту с использованием полного титула является обязательным для всех жителей страны.

Согласно Конституции Таджикистана (ч. 4 ст. 65), одно и то же лицо не может быть президентом более двух сроков подряд. Парламент Таджикистана 22 января 2016 г. принял поправки в Конституцию страны, согласно которым, в частности, действующий президент Таджикистана Эмомали Рахмон как Лидер нации может избираться на пост главы государства неограниченное количество раз. Согласно поправкам: «Ограничения, предусмотренные в части четвертой данной статьи, не распространяются на Основателя мира и национального единства - Лидера нации». Действующий президент Эмомали Рахмон был избран президентом Таджикистана в 1994 г. и переиз-

5 Конституция Республики Таджикистан принята на всеобщем референдуме 6 ноября 1994 года (внесены изменения и дополнения в результате референдума от 26.09.1999 г., 22.06.2003 г., http://www.base.spinform.ru/show_doc.fwx?rgn=2213 (дата обращения: 18.03.2018). 
бирался в 1999, 2006 и 2013 г. и каждый раз в промежутке между выборами проводя референдумы о внесении изменений в Конституцию, происходило «обнуление» его предыдущих сроков. Нынешний срок его полномочий завершается в ноябре 2020 года. Кроме того, согласно принятым поправкам, баллотироваться на пост президента Таджикистана сможет кандидат, достигший возраста 30 лет, а не 35 лет как того требует действующая Конституция. Установление единого возрастного ценза 30 лет распространяется так же на кандидатов в депутаты обеих палат парламента, судей Верховного суда, Конституционного суда и Высшего экономического суда Таджикистана.

Конституционный суд Таджикистана признал законными поправки в Основной закон страны. На состоявшемся 22 мая 2016 г. всенародном референдуме граждане Таджикистана поддержали внесение поправок в Конституцию (94,5\% - за, 3,3\% - против).

Конституционная реформа, состоявшаяся в Республике Армения, закрепила переход к парламентской форме правления. 6 декабря 2015 г. в Армении прошел референдум по конституционным изменениям (согласно официальным данным, в голосовании приняло участие 1.303 .466 человек (50,51\%), в поддержку конституционных реформ высказалось 825851 избирателей (63,35\%), против - $421600(32,35 \%))$.

Конституционная реформа, наряду с переходом к парламентской форме правления, предусмотрела изменение избирательной системы. Согласно ч. 3 ст. 89 Конституции Национальное Собрание избирается по пропорциональной избирательной системе.

Серьёзные изменения претерпел институт Президента. Согласно конституционной реформе, Президент республики получает ограниченные представительские функции. Президент Республики избирается Национальным Собранием, а не всенародным голосованием. Право на выдвижение кандидата в Президенты Республики имеет не менее чем одна четверть от общего числа депутатов парламента. Предусмотрено, что срок полномочий Президента увеличивается с 5 до 7 лет. Статья 124 Конституции Армении в редакции 2015 г. предусматривает, что Президентом Республики может быть избрано каждое лицо, достигшее сорока лет, последние шесть лет являющееся гражданином только Республики Армения, постоянно проживающее в Республике Армения последние шесть лет, обладающее избирательным правом и владеющее армянским языком. Весьма показательна часть 3 статьи 124 Конституции, закрепляющая: «одно и то же лицо может быть избрано Президентом Республики только один раз». Президент Республики не может занимать какую-либо иную должность, заниматься предпринимательской деятельностью, выполнять иную оплачиваемую работу. В ходе осуществления своих полномочий Президент Республики не может являться 
членом какой-либо политической партии. Правительство, согласно новой редакции Конституции, является высшим органом исполнительной власти (ст. 146). Правительство на основании своей программы вырабатывает и осуществляет внутреннюю и внешнюю политику. Премьер-министра назначает Президент, однако кандидатуру на пост главы кабинета будет выдвигать парламентское большинство. Вооруженные силы Армении подчиняются правительству, а в случае войны Премьер-министр становится Верховным главнокомандующим Вооруженными силами, в то время как, по действующей конституции, таковым является Президент республики.

На состоявшемся 26 сентября 2016 г. референдуме в Азербайджане были внесены изменения в Конституцию 1995 г. Отметим, что это по счету третий конституционный референдум с момента принятия действующей Конституции. В соответствии с конституционной реформой 2016 г. срок полномочий Президента увеличивается с 5 до 7 лет, он получил право объявлять внеочередные выборы Президента, право распускать Парламент (Милли Меджлис). По результатам референдума, в Азербайджане вводятся должности Первого Вице-президента и вице-президентов, которые назначаются Президентом страны. Отменяется возрастной ценз для избрания Президентом, который до сих пор составлял 35 лет, понижается возрастной порог для кандидатов в депутаты Милли Меджлиса с 25 до 18 лет.

В Кыргызстане на референдуме 11 декабря 2016 г. были приняты изменения в Конституцию Кыргызстана от 27 июня 2010 г. Закон «О внесении изменений в Конституцию Кыргызской Республики» от 28 декабря 2016 года № 218, подписанный Президентом страны, предусмотрел, в частности, расширение полномочий Премьер-министра (данные нормы в отличие от остальных поправок вступили в силу с 1 декабря 2017 г.). В частности, глава правительства может назначать и увольнять министров, если президент не издаст соответствующий акт, глав местных администраций без участия местных советов, а также получает право блокировать законопроекты, которые предусматривают увеличение расходов бюджета, возвращая их обратно в парламент. Кроме того, усложняется процедура выражения вотума недоверия правительству.

Началом реформы судебной системы в Российской Федерации стало принятие Закона РФ от 05.02.2014 № 2-ФКЗ «О Верховном Суде Российской Федерации и Прокуратуре Российской Федерации», которым предусмотрено упразднение Высшего Арбитражного Суда РФ. Согласно данному закону из Конституции РФ исключены все упоминания о Высшем Арбитражном Суде РФ, а все его полномочия передаются в юрисдикцию нового Верховного Суда РФ, который теперь является высшим судебным органом по гражданским делам, разрешению экономических споров, уголовным, админи- 
стративным и иным делам, подсудным судам, образованным в соответствии с федеральным конституционным законом, осуществляет в предусмотренных федеральным законом процессуальных формах судебный надзор за деятельностью этих судов и дает разъяснения по вопросам судебной практики. Кроме того, в ч. 1 ст. 104 Конституции РФ внесена поправка о том, что право законодательной инициативы из судебных органов принадлежит только Конституционному Суду РФ и Верховному Суду РФ по вопросам их ведения (ранее право законодательной инициативы принадлежало и Высшему Арбитражному Суду РФ). В статье 71 Конституции РФ, определяющей, что находится в ведении Российской Федерации, вместо гражданско-процессуального, уголовно-процессуального и арбитражно-процессуального законодательства теперь идет речь только о процессуальном законодательстве.

В развитие норм Закона о поправке к Конституции РФ принят целый ряд законов, вносящих многочисленные поправки в российское законодательство, связанные с ликвидацией Высшего Арбитражного Суда РФ и образованием нового Верховного Суда РФक. Внесенные изменения представляют собой существенную реформу российской судебной системы.

Как показывает политическая практика последнего десятилетия, через конституционные реформы политическая элита пытается трансформировать систему управления, отказываясь от президентской (или смешанной республиканской формы правления) в пользу парламентской республики. Достаточно очевидно, что несформировавшаяся многопартийная система в странах постсоветского пространства является серьезным препятствием для создания устойчивого и эффективного механизма управления страной. Высока вероятность перманентных парламентских и политических кризисов, т.е. политической нестабильности.

Показателен и еще один фактор, система правления, сложившаяся на постсоветском пространстве, предполагает, что действующий глава государства должен оставить после себя преемника. Демократизм подобной практики весьма сомнителен.

6 Федеральный конституционный закон от 05.02.2014 № 4-ФКЗ «О внесении изменений в Федеральный конституционный закон «О судебной системе Российской Федерации»; Федеральный конституционный закон от 05.02.2014 № 3-ФКЗ «О Верховном Суде Российской Федерации»; Федеральный конституционный закон от 04.06.2014 № 8-ФКЗ «О внесении изменений в Федеральный конституционный закон «Об арбитражных судах в Российской Федерации» и статью 2 Федерального конституционного закона «О Верховном Суде Российской Федерации»; Федеральный закон от 05.02.2014 № 16-Ф3 «О порядке отбора кандидатов в первоначальный состав Верховного Суда Российской Федерации, образованного в соответствии с Законом Российской Федерации о поправке к Конституции Российской Федерации «О Верховном Суде Российской Федерации и прокуратуре Российской Федерации». 
В конституциях постсоциалистических стран наблюдается определенное сходство набора составляющих их конституционно-правовых норм, институтов, принципов. Но такое сходство касается только общих черт. Другим аспектом выступает разнообразие конституционно-правовых институтов, обусловленных национальной спецификой, традициями, сложившимися в этих странах. В связи с чем, демократические принципы получают специфическое отражение, что искажает картину конституционного порядка.

В странах Западной Европы внутренним вызовом выступает кризис доверия граждан к власти и/или кризис власти. Это приводит к внесению поправок в конституции с целью, во-первых, усиления ответственности высших должностных лиц государства, и во-вторых, преодоления правительственного кризиса, в-третьих, усиления независимости судебной власти.

В отношении усиления ответственности высших должностных лиц государства показателен опыт Франции. Так, в 2007 г. во Франции прошла конституционная реформа, которая изменила ст. 68 Конституции в отношении оснований и процедуры смещения Президента Французской Республики с должности ${ }^{7}$, a 21 октября 2014 г. был принят Органический закон «О применении статьи 68 Конституции Франции» ${ }^{8}$. Отныне Президент Франции может быть смещен лишь в случае невыполнения им своих обязанностей, явно несовместимого с его мандатом (до реформы 2007 г. - за государственную измену). В частности, Органический закон предусмотрел, что решение о созыве Высокой палаты правосудия является результатом принятия предложенного решения обеими палатами Парламента. Предложение резолюции является мотивированным, оно подписывается по меньшей мере одной десятой частью членов палаты, которое его выдвигает. Закрепляются определенные гарантии против злоупотребления данным правом парламентариями: в течение одного президентского срока один парламентарий может поддержать только одно предложение о созыве Высокой палаты правосудия. Дебаты в Палате являются публичными. Помимо членов Палаты (парламентариев) в них могут участвовать только Президент Республики и Премьер-министр. Время для выступлений ограничено. Голосование должно начаться не позднее 48 часов после открытия дебатов. Голосование тайное, с использованием бюллетеней. Решение принимается большинством в две трети голосов соответствующей палаты или Высокой Палаты правосудия и немедленно вступает в силу. Любое делегирование голоса запрещается. При этом учи-

7 Конституция Французской Республики 1958 г., http://www.conseil-constitutionnel.fr/ conseil-constitutionnel/root/bank_mm/constitution/constitution_russe.pdf (дата обращения: 10.10.2017).

8 Органический закон «О применении статьи 68 Конституции Франции» от 21 октября 2014 г., http://www.senat.fr/leg/tas14-005.html (дата обращения: 10.10.2017). 
тывается только голоса, поданные за предложение об образовании Высокой Палаты правосудия или за смещение Президента Республики. Данный орган прекращает производство по делу, если он не вынес решение в месячный срок, предусмотренный ст. 68 Конституции Франции, что выступает определенной гарантией прав Президента Франции.

Следует согласиться с французским конституционалистом Б. Матье в том, что ответственность главы государства обратно пропорциональна размеру его компетенции 9 . Президент Французской Республики, обладая значительным объемом полномочий, до настоящей реформы (для проведения которой потребовалось 12 лет) на практике не мог быть смещен с должности.

С целью усиления принципа равенства 14 марта 2013 г. в Национальное собрание Франции от имени Президента Республики Ф. Олланда был внесен проект Конституционного закона «О судебной ответственности Президента Республики и членов Правительства» ${ }^{10}$. В соответствии с данным проектом Президент Республики лишается иммунитета в сфере гражданских исков, поскольку они касаются частных интересов и не препятствуют защите президентской функции. Вместе с тем, гражданский иск против Президента в течение срока его полномочий может быть возбужден только после разрешения комиссии по расследованию, образование которой предусматривается ст. 68-1 Конституции, при соблюдении условий, закрепленных в органическом законе. Более того, гражданский иск против Президента Республики не должен поставить под угрозу выполнение его обязанностей, ни наносить ущерб достоинству президентской должности.

В свою очередь члены Правительства утрачивают юрисдикционный иммунитет, в соответствии с которым за совершение действий при исполнении своих обязанностей, квалифицированных в момент их совершения как преступления или деликты, они были подсудны Суду правосудия Республики. Отныне предлагается упразднить этот орган, состоящий по сути из парламентариев (в его состав входит 12 парламентариев, избранных поровну в каждой палате Парламента, и 3 судьи Кассационного Суда), а также изменить процедуру для того, чтобы избежать злоупотреблений. Отныне члены Правительства могут быть привлечены к ответственности за действия, совершенные при исполнении своих обязанностей или после и только после разрешения комиссии по расследованию, состоящей из трех судей Кассационного суда, двух членов Государственного совета и двух судей Счетной палаты, которые назначаются на пять лет. В комиссию могут обращаться: прокуратура, орган расследования или лицо, считающее себя пострадавшим

9 B. Mathieu, Statut pénal du Président de la République, La semaine juridique 22 décembre 2014, № 52, p. 2392.

10 http://www.assemblee-nationale.fr/14/projets/pl0816.asp (дата обращения: 20.04.2018). 
от действия члена Правительства. Комиссия принимает решение в течение шести месяцев с момента запроса. В случае одобрения комиссии дело в отношении члена Правительства может быть возбуждено в соответствии с общим правом. Рассмотрение дел будет осуществляться компетентными судами г. Парижа, состоящими не менее чем из трех судей. Примечательно, что данный проект конституционной реформы так и не нашел своего логического завершения: он не был поставлен на голосование в Национальном собрании и не был рассмотрен в Сенате.

Вторым направлением конституционных преобразований в странах Западной Европы выступают институциональные реформы в целях преодоления правительственного (политического) кризиса. Ярким примером является реформирование итальянского парламента, начавшееся в марте 2015 г., когда Палата депутатов итальянского Парламента приняла конституционный закон, имеющий целью обеспечение стабильности правительства путем значительного уменьшения полномочий Сената (верхней палаты Парламента Италии).

Проект конституционной реформы предусматривал изменение существующей в стране модели «равноправного бикамерализма», признанной источником политической нестабильности, поскольку, обладая тем же кругом полномочий, что и Палата депутатов, Сенат формировался на региональной основе, а не на национальной, что увеличивало риск иметь две палаты с разным большинством голосов. Конституционная реформа предлагала уменьшение состава Сената с 315 сенаторов до 95 (90 представляют территориальные учреждения, пять назначаются Президентом Республики), изменение порядка его формирования и срока полномочий (отныне он совпадает со сроком полномочий органов территориальных учреждений, от которых они избраны, срок полномочий сенаторов по назначению составляет семь лет).

В результате предлагаемой конституционной реформы в Италии предусматривалось значительное ограничение законодательных полномочий Сената: если ранее законодательная функция осуществлялась совместно палатами Парламента, отныне - совместно в обязательном порядке только по определенным в ст. 70 Конституции Итальянской Республики вопросам (например, в отношении конституционных законов, законов о референдуме, избирательных законов и пр., перечень закрытый), другие законы - факультативно по требованию не менее $1 / 3$ его членов. Сенат должен был утратить право разрешать объявление войны (теперь - только Палата депутатов обладает таким правом), лишиться права путем издания законов разрешать ратификацию международных договоров (за исключением договоров, связанных с членством Италии в Европейском Союзе), права выражать вотум недоверия Правительству и оказывать ему доверие. С другой стороны, отныне Сенат 
не может быть распущен Президентом Республики (ст. 88 Конституции Италии). Такое действие возможно только в отношении Палаты депутатов.

В целом, предлагаемые изменения конституционно-правового статуса Сената Италии свидетельствуют о значительном уменьшении его полномочий и роли в государственном механизме и делают его «похожим» на верхние палаты парламентов многих европейских государств, использующих модель «неравноправного бикамерализма». Возможно, данные модификации и помогли бы укрепить исполнительную власть и обеспечить политическую стабильность в Италии, если бы не отрицательное голосование граждан на конституционном референдуме 4 декабря 2016 г.

В целях усиления основ правового государства в ряде европейских государств корректируются конституционные положения, относящиеся к судебной власти.

Работа по подготовке текста новой конституции вследствие изменения общественных отношений, требующих конституционализации с учетом современных вызовов, в настоящее время идет и в отдельных странах Западной Европы. В частности, Палата депутатов Люксембурга 13 марта 2015 г. опубликовала текст проекта новой Конституции Великого Герцогства Люксембур $\Gamma^{11}$, который отвечает требованиям современной демократии, исключает устаревшую терминологию, закрепляет реальную практику функционирования государственных органов и должен заменить Конституцию 1868 г., действующую с многочисленными поправками.

Среди принципиальных изменений-новшеств проекта новой Конституции Люксембурга следует отметить положения о независимости судебной власти и прокуратуры. 6 июня 2018 г. депутаты Парламента Люксембурга приняли доклад, который является заключительным в отношении новой Конституции. Проведение голосования в Парламенте по проекту новой Конституции планируется после проведения парламентских выборов в октябре 2018 г., второе голосование должно быть проведено путем референдума.

Во Франции данное направление получает свое развитие в ходе июльской конституционной реформы 2008 г. В разделе VIII Конституции - «О судебной власти» в свете усиления независимости судебной власти в новой редакции изложена ст. 65, в соответствии с которой расширяется состав Высшего Совета магистратуры, Президент Республики лишается права председательствовать в нем, Министр юстиции перестает быть его вице-председателем, судьи перестают составлять большинство членов Совета, а его полномочия увеличиваются. Следующий этап - внесение Президентом Республики 14 марта

11 Проект новой Конституции Великого Герцогства Люксембург от 13.03.2015 г., http:// www.chd.lu (дата обращения: 20.04.2018). 
2013 г. в Национальное собрание Франции проекта конституционного закона «О реформе Высшего совета магистратуры» ${ }^{12}$ с целью усиления гарантий независимости судебной власти. Данный проект одновременно усиливает независимость Высшего совета магистратуры от любого политического вмешательства как при его формировании, так и при его функционировании, а также усиливает его полномочия. В частности, отныне он может по собственной инициативе рассматривать любой вопрос, относящийся к деонтологии судей и независимости судебных органов, а не только переданные ему на рассмотрение заявления по этим вопросам от имени Президента Республики. Представляется, что в этом смысле правовая конструкция статьи 64 Конституции Франции дает возможность для «конкуренции» в данной сфере между Президентом Республики, являющимся гарантом независимости судебной власти, и Высшим советом магистратуры, который посредством принятия своих решений, ему в этом помогает. Проект данного конституционного закона был окончательно принят во втором чтении Национальным собранием 26 марта 2016 года.

Тенденция усиления независимости судебной власти наблюдается и в Великобритании, где Актом о конституционной реформе 2005 г. были изъяты судебные полномочия у Палаты лордов Британского Парламента и переданы вновь учреждаемому органу - Верховному Суду, который стал высшей судебной инстанцией Великобритании и начал свою деятельность с 1 октября 2009 года.

Таким образом, конституционные изменения в зарубежных странах демонстрируют многообразие конституционных решений, отражающих вызовы современного мира. Конституция государства выступает важнейшим инструментом и фундаментом для дальнейших реформ. Анализ практики конституционных преобразований на постсоветском пространстве и в странах Западной Европы позволяет выделить их различные направления, обусловленные, прежде всего, дифференцированными внутренними вызовами, историческими, правовыми особенностями развития государств, различной степенью развития правовой культуры.

\section{Резюмe}

В данной статье определяются внешние и внутренние вызовы и угрозы, выступающие катализатором конституционных преобразований в современном мире. Выделяются основные направления и отличия происходящих конституционных преобразований в постсоветских республиках и странах Западной Европы.

12 B. Mathieu, Statut pénal du Président de la République, La semaine juridique 22 décembre 2014, № 52, p. 2392. 
Natalia M. Kondratovich, Tatiana S. Maslovskaya

\section{CONSTITUTIONAL TRANSFORMATIONS IN THE CIS AND WESTERN EUROPE: AN EVOLUTIONARY NEED OR RESPONSE TO MODERN CHALLENGES}

This article defines external and internal challenges and threats that act as a catalyst for constitutional changes in the modern world. The main directions and differences of the ongoing constitutional reforms in the post-Soviet republics and countries of Western Europe are singled out.

KEY WORDS: constitution, constitutional development, constitutional reform, modern challenges, foreign countries

\section{Библиография}

R. V. Engibaryan, Constitutional Development in the Modern World, Moscow 2010.

B. Mathieu, Criminal Statute of the President of the Republic, «The Legal Week» 22 December 2014, № 52.

The Constitution of the French Republic of 1958, http://www.conseil-constitutionnel.fr/ conseil-constitutionnel/root/bank_mm/constitution/constitution_eng.pdf, (дата обращения: 10.10.2017).

The Constitutional Law of the Republic of Kazakhstan «On the First President of the Republic of Kazakhstan - Leader of the Nation» of July 20, 2000 N 83-II, http://www.akorda.kz/ ru/official_documents/constitution, (дата обращения: 18.03.2018).

The Constitution of the Republic of Kazakhstan was adopted at a referendum on August 30, 1995 (amendments and additions were made on October 7, 1998, May 21, 2007, February 2, 2011), http://www.akorda.kz/ru/official_documents/constitution, (дата обращения: 18.03.2018).

The Law of the Republic of Kazakhstan "On Amending the Constitution of the Republic of Kazakhstan” of February 2, 2011 No. 403-IV, http://www.akorda.kz/ru/official_documents/ constitution, (дата обращения: 18.03.2018).

The Constitution of the Republic of Tajikistan was adopted at the general referendum on November 6, 1994 (amendments and additions were made as a result of the referendum of September 26, 1999, June 22, 2003), http://www.base.spinform.ru/show_doc.fwx ? rgn = 2213, (дата обращения: 18.03.2018).

The Organic Law «On the Application of Article 68 of the Constitution of France» of October 21, 2014, http://www.senat.fr/leg/tas14-005.html, (дата обращения: 10.10.2017). 
Омон Закирович Мухамеджанов

ORCID: 0000-0002-0320-328X

\section{Усиление роли конституционного правосудия \\ в защите прав и свобод человека: основные тенденции, проблемы и перспективы 1}

\section{КЛЮЧЕВЫЕ СЛОВА:}

Конституциионный суд, полномочия Конституцฺионного суда, конституциионное правосудие, конституционное судопроизводство, статус судьи

\section{Введение}

Важнейшим условием формирования правового государства является обеспечение верховенства Конституции над издаваемыми законами и иными нормативно-правовыми актами, что предполагает необходимость ее особой правовой защиты. Воплощение в жизнь и демократического правового государства напрямую зависит от того, насколько эффективно действует механизм охраны Конституции. Главным определяющим элементом этого механизма является конституционный контроль².

1 The article is written as a part of National Science Centre (Poland) project: Constitutional courts in post-Soviet states: Between the model of a state of law and its local application (id 2016/23/B/HS5/03648).

2 В правовой литературе наметились два основных направления в исследовании сущности конституционного контроля: 1) рассмотрение его в качестве элемента системы разделения властей: 2) в качестве организационно-правовой формы механизма юридической охраны конституции (см.: Т. Я. Насырова, Конституционный контроль, Казань 1992, с. 7, 8). В. Е. Чиркин предлагает иной подход к определению места института конституционного контроля в механизме разделения властей. В частности, он говорит о наметившейся в современном мире тенденции в системе разделения властей, а именно - обособлении контрольной власти (см.: В. Е. Чиркин, Контрольная власть, «Государство и право» 1993, № 4, с. 11, 12). Французский государствовед Л. Фаворе придерживается другой точки зрения. Суть ее состоит в том, что конститу- 
Конституция как политико-правовой документ определяет основы конституционного строя и определяет условия и принципы формирования всех ветвей власти. Основная роль конституционного контроля в укреплении системы сдержек и противовесов заключается в строгом соблюдении конституционных принципов. В случае злоупотребления одной из ветвей власти и превышением полномочий предусмотренных Конституцией, задача органа конституционного контроля состоит в требовании соблюдения положений Конституции и не превышении рамок компетенции, через имеющиеся конституционные полномочия и правовые механизмы.

Система конституционного правосудия может эффективно и полноценно функционировать при наличии определенных необходимых и достаточных предпосылок. К их числу можно отнести: функциональную, институциональную, организационную, материальную, социальную независимость судебного конституционного контроля; последовательность в конституционном осуществлении принципа разделения властей; адекватность и сопоставимость основных конституционных принципов и соответствующих конституционных механизмов осуществления государственной власти; правильный и обоснованный выбор объектов конституционного контроля; определение оптимального круга субъектов, имеющих право обращаться в Конституционный суд; системный подход при обеспечении функциональной полноценности судебной власти; наличие и осуществление четкой законотворческой политики; необходимый уровень восприятия демократических ценностей в обществе.

Место Конституционного суда в системе высших органов государства определяется необходимостью обеспечения единства системы законодательства, устранения в нем противоречий, соответствия всех нормативных актов Конституции. Деятельность органа, осуществляющего конституционный контроль, является существенным элементом государственного механизма, построенного на принципах разделения властей, т.к. позволяет контролировать соблюдение каждым органом закрепленной за ним компетенции.

Успешное развитие независимого Узбекистана обоснованно связывается со стабильностью конституционного строя, с выражением в Конституции ценностных ориентиров общества. Именно Конституция интегрирует в себе и возводит на высший нормативно-правовой уровень основные идеи, нормы и направления демократического развития общества и государства.

После обретения Узбекистаном независимости в августе 1991 г. возникла потребность в коренных преобразованиях государственно-правовой

ционное правосудие находится вне трех властей, обеспечивая соблюдение ими своих полномочий (см.: L. Favore, Les cours constitutionnelles, Paris, 1992, c. 14). 
сферы, принятии комплекса законов для обеспечения перехода от старого административно-командного стиля управления, при котором идеология главенствовала над законом, к подлинно демократическому правовому государству и обществу, обеспечивающему приоритет принципов и норм Конституции страны.

За короткий период времени были сделаны значительные шаги в области реформирования судебно-правовой сферы, начало которому положило принятие Конституции Узбекистана 8 декабря 1992 г. $^{3}$, закрепившей основные принципы независимости судебной власти, основанной на осуществлении правосудия, главной целью которого является защита прав и законных интересов человека.

Обеспечение верховенства Конституции осуществление контроля за ее соблюдением реализуется посредством функционирования различных моделей конституционного правосудия ${ }^{4}$. Например, действуют специализированные и неспециализированные органы, призванные не допускать принятия законов и иных нормативно-правовых актов, противоречащих конституции. В частности, специализированный конституционный контроль представляет собой важнейший и действенный способ защиты верховенства конституции юридическими средствами 5 .

В настоящее время в рамках укрепления правовых гарантий обеспечения прав человека актуализировалась необходимость сравнительно-правового исследования конституционного законодательства государств Центральной Азии, большое значение приобрел анализ сущности и тенденций трансформации института конституционного контроля, изучение особенностей объекта конституционного контроля, специфики деятельности субъектов конституционного контроля, усиления роли органов конституционного контроля в сфере защиты прав, свобод и законных интересов человека.

За прошедшие годы в Республике Узбекистан создана последовательно развивающаяся модель конституционного контроля с учетом мировых тенденций конституционной юстиции, при этом обеспечиваются конституционная идентичность и особенности развития узбекской государственности. Необходимость глубокого изучения организационно-правового механизма осуществления конституционного правосудия в Узбекистане, направлена на его оптимизацию и совершенствование форм и методов конституционного правосудия на основе существенного обновления Закона о Конституцион-

3 См.: Конституция Республики Узбекистан, Ташкент 2018.

4 См.: В. Е. Чиркин (ред.), Сравнительное конституционное право. Учебное пособие, Москва 2002, с. 95-104.

5 См.: А. С. Автономов, Конституционное (государственное) право зарубежных стран, Москва 2012, с. 68. 
ном суде Республики Узбекистан, осуществленного в 2017 году 6 . Пересмотр указанного закона предоставляющий индивидам больше шансов и возможностей по защите своих прав и свобод, т.к. в результате деятельности Конституционного суда уменьшатся возможности для нарушений прав и свобод человека и гражданина.

\section{Основные этапы формирования и организации деятельности конституционного правосудия в Узбекистане}

Конституционный контроль ${ }^{7}$ в Республике Узбекистан начал формироваться в марте 1990 г., когда был создан Комитет конституционного надзора, который избирался Верховным советом ${ }^{8}$. Принятый 20 июня 1990 г. Закон Республики Узбекистан “О конституционном надзоре Республики Узбекистан"9 впервые в истории страны закрепил основы конституционного квазисудебного контроля. Хотя Законом был введен конституционный надзор, а не правосудие, во многом Комитет конституционного надзора Республики Узбекистан, а также Комитет конституционного надзора Республики Каракалпакстан выполняли функции судебного органа. Они обеспечивали соответствие актов государственных органов и общественных организаций соответственно Конституции Республики Узбекистан и Конституции Республики Каракалпакстан, охрану конституционных прав и свобод личности, прав народов Республики Узбекистан и Республики Каракалпакстан, демократических основ общества.

В вышеуказанном законе определялись основные принципы деятельности органов конституционного надзора (законность, коллегиальность и гласность) порядок их избрания (избрание парламентом по представлению его председателя сроком на 10 лет, обновление состава наполовину каждые пять лет), досрочного прекращения полномочий судей, полномочия и порядок деятельности Комитета конституционного надзора Республики Узбекистан.

6 См.: Конституционный закон Республики Узбекистан «О Конституционном суде», Ведомости Олий Мажлиса Республики Узбекистан, Собрание законодательства Республики Узбекистан 2017, № 22, ст. 407.

7 Если обратиться к анализу понятий «Конституционный контроль», «Конституционный надзор» функция контроля более активна, поскольку признание нормативного акта (или его положения) не соответствующей Конституции влечет за собой утрату его силы, а надзорная функция имеет целью обратить внимание органов и должностных лиц на неконституционность принятых или изданных ими нормативных актов и вызвать соответствующие меры.

8 См.: Ведомости Верховного Совета Республики Узбекистан 1990, № 10-11, ст. 226.

9 См.: Ведомости Верховного Совета Республики Узбекистан 1990. № 16-18, ст. 289. 
Система конституционного контроля изменялась в рамках проводимой (и продолжающейся по сей день) реформы системы правосудия. На первоначальном этапе судебно-правовой реформы была определена национальная стратегия коренного реформирования судебно-правовой системы и созданы её конституционно-правовые основы. Была решена задача по формированию целостной системы судебной власти, направленной на преобразование суда из органа, карающего и защищающего интересы только государства, в орган, обеспечивающий верховенство закона и защиту прав человека.

С учетом мирового опыта в стране вместо Комитета конституционного надзора был учрежден Конституционный суд. Как и в странах постсоветского пространства при учреждении Конституционного суда Республики Узбекистан была использована классическая европейская (кельзеновская) модель централизованного конституционного контроля. Выбор европейской централизованной модели обусловлен, на наш взгляд, рядом причин:

Во-первых, в период трансформаций и реформ в конце XX века усиливалась роль всех ветвей власти и необходимость реализации принципа разделения властей.

Во-вторых, процессы формирования правовых государств бывшего СССР требовали концентрации усилий в формировании новой государственности, обеспечении динамичности общественного развития, устойчивости политических процессов, формировании национальных правовых систем.

B-третьих, учреждение специального органа конституционного контроля - Конституционного суда с конституционными полномочиями определяло его роль "хранителя" Конституции.

Президентом Республики Узбекистан был принят Указ от 2 июня 2000 г. № УП-2612 “О мерах по реализации Программы по либерализации и углублению реформ в политической, экономической и духовной сферах общества, обеспечению безопасности страны" 10 . В Программе были предусмотрены в числе других меры по совершенствованию конституционного правосудия.

Указом Президента Республики Узбекистан от 14 августа 2000 г. “О совершенствовании судебной системы Республики Узбекистан”"1 определены задачи реформирования и дальнейшего углубления демократических основ судебной системы. Логическим завершением первоначального этапа реформирования судебно-правовой сферы стало принятие 14 декабря 2000 г. Закона Республики Узбекистан "О судах"12 в новой редакции, отразившего на законодательном уровне фундаментальные гарантии независимости и самостоятельности судебной власти, её эффективности.

10 Cм.: URL: http://lex.uz/pages/GetAct.aspx?lact_id=202004 (дата обращения: 27.02.2018).

11 См.: Ведомости Олий Мажлиса РУз. 2000, № 7-8, ст. 246.

12 См.: Ведомости Олий Мажлиса РУз. 2001, № 1-2, ст. 10. 
Важнейшей программной задачей следующего этапа явились укрепление независимой судебной системы, защита прав и свобод человека. Характерной чертой данного этапа стали меры по дальнейшей демократизации и либерализации судебно-правовой системы, повышению авторитета суда, обеспечению исполнения судебных решений и получения квалифицированной юридической помощи.

Дальнейшее кардинальное реформирование судебно-правовой системы связано с принятием Указа Президента Республики Узбекистан «О Стратегии действий по дальнейшему развитию Республики Узбекистан» от 7 февраля 2017 г. № УП-494713. В данном документе приоритетными направлениями дальнейшего реформирования судебно-правовой системы стали: повышение статуса, уровня материального стимулирования и социального обеспечения судей и работников аппарата суда, укрепление материально-технической базы судов; принятие действенных мер по недопущению неправомерного воздействия на судей; всемерная реализация принципов независимости и беспристрастности суда, состязательности и равноправия сторон судебного процесса; внедрение современных информационно-коммуникационных технологий в деятельность судов.

В апреле 2017 г. вступил в силу Закон Республики Узбекистан № ЗРУ426 «О внесении изменений и дополнений в Конституцию Республики Узбекистан» ${ }^{14}$, содержащий принципиальные положения, направленные на реализацию задач, определённых в Стратегии действий по пяти приоритетным направлениям развития Республики Узбекистан в 2017-2021 гг. Поправки в Основной закон страны были внесены в соответствии с указами Президента Республики Узбекистан от 21 октября 2016 г. № УП-4850 «О мерах по дальнейшему реформированию судебно-правовой системы, усилению гарантий надежной защиты прав и свобод граждан» ${ }^{15}$ и от 21 февраля 2017 г. № УП-4966 «О мерах по коренному совершенствованию структуры и повышению эффективности деятельности судебной системы Республики Узбекистан» ${ }^{16}$.

В соответствии с указанными поправками Высший хозяйственный суд и Верховный суд объединены в единый высший орган судебной власти в сфере гражданского, уголовного, административного и экономического судопроизводства - Верховный суд Республики Узбекистан. В судебноправовую систему введен новый институт - Высший судейский совет Республики Узбекистан, заменивший ранее действовавшую Высшую ква-

13 См.: Собрание законодательства Республики Узбекистан 2017, № 6, ст. 70.

14 См.: Собрание законодательства Республики Узбекистан 2017, № 14, ст. 213.

15 См.: Собрание законодательства Республики Узбекистан 2016, № 43, ст. 497.

16 См.: Собрание законодательства Республики Узбекистан 2017, № 8, ст. 109. 
лификационную комиссию по отбору и рекомендации на должности судей при Президенте Республики Узбекистан. Конституция наделила Высший судейский совет широкими полномочиями. Совет по согласованию с главой государства самостоятельно назначает и освобождает от должности судей военных судов, судов областей и города Ташкента, председателей и судей межрайонных, районных, городских судов.

31 мая 2017 года был принят Закон Республики Узбекистан № 3РУ-430 «О внесении изменений в отдельные статьи Конституции Республики Узбекистан (ст. 80, 93, 108 и 109)»17. Закон направлен на реализацию задач по реформированию судебно-правовой сферы, расширению гарантий надежной защиты прав и свобод граждан, повышению уровня их доступа к правосудию, эффективности и качества судопроизводства, дальнейшему совершенствованию системы отбора кандидатов и назначения на должности судей.

В целях совершенствования конституционного правосудия в рамках проводимой судебной реформы принят в новой редакции закон Республики Узбекистан «О Конституционном суде Республики Узбекистан», который ввел новый порядок избрания Конституционного суда, уточнил и существенно расширил его полномочия ${ }^{18}$. Совершенствование института конституционного контроля в Республике Узбекистан означает дальнейшую реализацию на практике принципа разделения властей, воплощение в жизнь эффективного механизма охраны Конституции.

Принятие вышеназванного Закона свидетельствует о возрастании роли конституционного правосудия в современном Узбекистане посредством:

- усиления гарантий и расширения возможностей института конституционного правосудия;

- конкретизации полномочий органа конституционного правосудия, с целью укрепления гарантий прямого действия и охраны Конституции;

- совершенствования форм реализации функций и полномочий Конституционного суда;

- расширения мониторинга и оценки нарушений верховенства Конституции;

- демократизации формирования состава Конституционного суда, уточнение требований к кандидатам в члены указанного органа конституционного правосудия;

- введения в научный оборот правовой науки такого термина, как «конституционное правосудие», исследование сути, содержания и характеристик

17 См.: Собрание законодательства Республики Узбекистан 2017, № 22, ст. 406.

18 См.: Собрание законодательства Республики Узбекистан 2017, № 22, ст. 406; Собрание законодательства Республики Узбекистан 2017, № 22, ст. 407, № 37, ст. 978. 
указанной особой ветви правосудия, поскольку Конституционный суд, будучи судебным органом, осуществляет правосудие.

Таким образом, формирование и развитие конституционного правосудия в Республике Узбекистан, в том числе, эволюция правовых основ его деятельности осуществлялись в несколько этапов:

I. 1990-1992 гг. - период учреждения и становления конституционного надзора. Данный этап характеризовался определением конституционноправового статуса Комитета конституционного надзора как органа, имеющего контрольно-надзорные функции.

II. 1993-2016 гг. - деятельность Конституционного суда по конституционализации процессов, связанных с активным формированием системы конституционного правосудия страны. На основе Конституции Республики Узбекистан был принят Закон «О Конституционном суде Республики Узбекистан» 19 , в котором были уточнены роль и место Конституционного суда в системе судебной власти, с учетом нового конституционноправового статуса.

В этот период происходил процесс формирования национальной системы законодательства на основе развития положений Конституции и общепризнанных принципов и норм международного права. Основные усилия Конституционного суда были направлены на оценку соблюдения в законодательстве и правоприменительной практике конституционных положений, их полную и последовательную реализацию, разработку на законодательном уровне механизмов осуществления конституционных прав и свобод граждан. Конституционным судом принимались также решения, направленные на исключение пробелов и коллизий в законодательстве.

III. Современный этап развития берет свое начало с принятия Указа Президента Республики Узбекистан «О Стратегии действий по дальнейшему развитию Республики Узбекистан» от 7 февраля 2017 г. № УП-494720. Данный этап развития конституционного правосудия направлен на расширение полномочий Конституционного суда, повышение его роли в жизни общества и государства. Такая постановка задач обусловлена необходимостью обеспечения прямого действия Конституции страны, ее верховенства. В условиях сформировавшейся правовой системы, достигнутой политической, социальной стабильности в стране, тесного взаимодействия властей в законотворческом процессе упор делается на расширение прав Консти-

19 Закон Республики Узбекистан «О Конституционном суде», Ведомости Олий Мажлиса Республики Узбекистан. 1995 № 9, ст. 178.

20 См.: Собрание законодательства Республики Узбекистан 2017, № 6, ст. 70. 
туционного суда в сфере обеспечения конституционных прав и законных интересов граждан.

\section{Правовые основы, принципы формирования Конституционного суда Республики Узбекистан и правовой статус судей}

Конституционный суд является постоянно действующим органом и избирается сроком на пять лет. В соответствии со ст. 5 Закона «О Конституционном суде Республики Узбекистан» Конституционный суд избирается Сенатом Олий Мажлиса Республики Узбекистан по представлению Президента Республики Узбекистан из числа лиц, рекомендованных Высшим судейским советом Республики Узбекистан, включая представителя от Республики Каракалпакстан. Каждый судья Конституционного суда избирается в индивидуальном порядке. Одно и то же лицо не может быть избрано судьей Конституционного суда более двух раз. Избранным считается лицо, получившее большинство голосов от общего числа членов Сената Олий Мажлиса Республики Узбекистан.

В ст. 9 Закона подчеркивается, что судьи Конституционного суда, принимая решения, выражают свою правовую позицию, свободную от соображений практической целесообразности, политических склонностей и других посторонних воздействий. В соответствии со ст. 19 Закона судьи Конституционного суда не могут быть сенаторами, депутатами представительных органов государственной власти. Судьи Конституционного суда не могут состоять членами политических партий, участвовать в политических движениях, а также заниматься какими-либо другими видами оплачиваемой деятельности, кроме научной и педагогической.

Конституционный суд состоит из семи судей Конституционного суда, включая председателя и его заместителя. Председатель Конституционного суда и его заместитель избираются из числа судей Конституционного суда на его заседании. В соответствии с законом судьей Конституционного суда может быть избран гражданин Республики Узбекистан не моложе тридцати пяти лет из числа специалистов в области политики и права, обладающий высокими моральными качествами и необходимой квалификацией (ст. 16 Закона «О Конституционном суде Республики Узбекистан»).

Конституционным законом «О Конституционном суде Республики Узбекистан» предусмотрено, что судьи Конституционного суда в период исполнения своих полномочий несменяемы. Принцип несменяемости судей Конституционного суда означает, что полномочия судей Конституционного 
суда могут быть прекращены досрочно только в предусмотренных законом случаях по решению Сената Олий Мажлиса Республики Узбекистан. Законом предусмотрены следующие основания для прекращения полномочий судьи Конституционного суда:

- нарушения им присяги судьи;

- подачи им письменного заявления;

- достижения им предельного возраста пребывания в должности судьи;

- вступления в отношении него в законную силу обвинительного приговора суда;

- продолжения судьёй деятельности, несовместимой с должностью судьи, после сделанного ему предупреждения или приостановления его полномочий;

- его неспособности по состоянию здоровья или иным уважительным причинам в течение длительного времени исполнять обязанности судьи;

- утраты им гражданства Республики Узбекистан;

- признания его в установленном порядке недееспособным или ограниченно дееспособным;

- смерти или объявления его умершим решением суда.

Традиционно, судьи Конституционного суда отбираются из числа судей общей юрисдикции и хозяйственных судов ${ }^{21}$.

Судьи Конституционного суда обладают иммунитетом и не могут быть привлечены к уголовной и административной ответственности, а также заключены под стражу без согласия Конституционного суда Республики Узбекистан. Уголовное дело в отношении судьи Конституционного суда может быть возбуждено только Генеральным прокурором. Не допускается привод, задержание, а равно досмотр личных вещей, багажа, транспорта, жилого, служебного помещения судьи Конституционного суда.

Полномочия судьи Конституционного суда могут приостанавливаться решением Конституционного суда в следующих случаях: привлечение его к уголовной ответственности; занятия им деятельностью, несовместимой с должностью судьи; признания его безвестно отсутствующим решением суда. Приостановление полномочий судьи, за исключением случаев, когда судье в качестве меры пресечения было избрано заключение под стражу, не влечёт за собой приостановления выплаты ему заработной платы и не лишает его гарантий неприкосновенности. Полномочия судьи Конституци-

21 Так, судья Генжемурат Пиржанов имеет судейский стаж в судах общей юрисдикции, бывшая судья Фатима Хусанова много лет проработала судьей Ташкентского городского суда по гражданским делам. Бывший председатель Конституционного суда Мирза-Улугбек Абдусаломов до этого долгое время руководил Высшим хозяйственным судом. 
онного суда приостанавливаются до отпадения оснований к их приостановлению.

В ст. 14 Кодекса чести судьи Конституционного суда Республики Узбекистан, утвержденным Конституционным судом Республики Узбекистан 30 января 2004 года (внесено изменение 17 апреля 2015 года) за совершение должностного или иного преступления судья несет ответственность в соответствии с законодательством.

За совершение поступка, дискредитирующего Конституционный суд, полномочия судьи могут быть приостановлены либо досрочно прекращены в установленном порядке.

Ст. 79 Регламента Конституционного суда Республики Узбекистан гласит, что приостановление полномочий судьи Конституционного суда осуществляется по решению Конституционного суда, принимаемому не позднее месяца со дня выявления основания к их приостановлению. Приостановление полномочий судьи Конституционного суда в случае привлечения его к уголовной ответственности осуществляется одновременно с дачей согласия на привлечение его к уголовной ответственности.

Конституционный суд приостанавливает полномочия судьи до отпадения основания к их приостановлению. Восстановление полномочий судьи оформляется решением Конституционного суда.

В ст. 24 Конституционного закона «О Конституционном суде Республики Узбекистан», где говорится о гарантиях по трудоустройству судей Конституционного суда после окончания их полномочий указывается, что судьям Конституционного суда после окончания их полномочий предоставляется прежняя работа (должность), занимаемая ими до избрания на должность судьи Конституционного суда, а при ее отсутствии - другая равноценная работа (должность).

Основными принципами деятельности Конституционного суда являются верховенство Конституции Республики Узбекистан, независимость, коллегиальность, гласность, состязательность и равноправие сторон (ст. 7 Конституционного закона о Конституционном суде Республики Узбекистан). Судьи, принимая решения, выражают свою правовую позицию, свободную от соображений практической целесообразности, политических склонностей и других посторонних воздействий.

Независимость Конституционного суда обеспечивается установленным Конституцией порядком избрания судей Конституционного суда и их освобождения, неприкосновенностью, юридической процедурой разрешения дел и вопросов, относящихся к компетенции суда, тайной совещания судей при вынесении решений, ответственностью за неуважение к Конституционному суду или вмешательство в его работу, созданием необходимых 
организационно-технических условий для деятельности Конституционного суда, а также материальным и социальным обеспечением судей.

Компетенция и повседневная деятельность Конституционного суда воплощают в себе независимость судебной власти от законодательной и исполнительной власти как один из важнейших конституционных принципов. В отличие от других судов Конституционный суд рассматривает и разрешает дела о конституционности актов законодательной и исполнительной власти, даёт заключения, руководствуясь исключительно Конституцией Республики Узбекистан. Он обеспечивает верховенство Конституции путем разрешения вопросов, внесённых на его рассмотрение.

Конституционный суд рассматривает дела о конституционности актов законодательной и исполнительной власти и по итогам их рассмотрения принимает соответствующее решение.

В целях организационного, научно-экспертного, информационносправочного и иного обеспечения деятельности Конституционного суда в его структуре создается аппарат (ст. 35 Конституционного закона «О Конституционном суде Республики Узбекистан»). Положение об аппарате Конституционного суда Республики Узбекистан утверждено Конституционным судом Республики Узбекистан 17 апреля 2015 года. Основной задачей Аппарата является организационно-техническое, научно-аналитическое, информационно-справочное и финансово-хозяйственное обеспечение деятельности Конституционного суда.

\section{Место Конституционного суда в системе разделения государственной власти на законодательную, исполнительную и судебную ветви власти}

Взаимоотношения Конституционного суда и Президента Республики Узбекистан осуществляются по вопросам:

Во-первых, в соответствии со ст. 25 Конституционного закона «О Конституционном суде Республики Узбекистан» Президент Республики Узбекистан обладает правом внесения на рассмотрение Конституционного суда вопросов, рассмотрение которых отнесено к его компетенции Конституцией и законами, но такое полномочие пока не использовано.

Во-вторых, взаимодействие Конституционного суда с Президентом Республики Узбекистан в соответствии с законодательством осуществляется в рамках формирования судебного корпуса. Согласно ст. 5 вышеназванного Закона Конституционный суд избирается Сенатом Олий Мажлиса Республики Узбекистан по представлению Президента Республики Узбекистан 
из числа лиц, рекомендованных Высшим судейским советом Республики Узбекистан, включая представителя от Республики Каракалпакстан. Каждый судья Конституционного суда избирается в индивидуальном порядке. Избранным считается лицо, получившее большинство голосов от общего числа членов Сената Олий Мажлиса Республики Узбекистан.

В-третьих, в соответствии со ст.95 Конституции Республики Узбекистан и ст. 76 Регламента Конституционного суда Республики Узбекистан Конституционный суд при принятии решения о даче согласия Президенту Республики Узбекистан на принятие решения о роспуске Законодательной палаты, Сената Олий Мажлиса Республики Узбекистан устанавливает наличие или отсутствие фактов:

- возникновения в составе Законодательной палаты или Сената Олий Мажлиса Республики Узбекистан непреодолимых разногласий, ставящих под угрозу их нормальное функционирование;

- неоднократного принятия ими решений, противоречащих Конституции Республики Узбекистан;

- возникновения непреодолимых разногласий между Законодательной палатой и Сенатом, ставящих под угрозу нормальное функционирование Олий Мажлиса Республики Узбекистан.

По итогам рассмотрения дела Конституционный суд вправе принять одно из следующих решений:

- о даче согласия Президенту Республики Узбекистан на принятие решения о роспуске Законодательной палаты, Сената Олий Мажлиса Республики Узбекистан;

- об отказе в даче согласия Президенту Республики Узбекистан на принятие решения о роспуске Законодательной палаты, Сената Олий Мажлиса Республики Узбекистан.

В-четвертых, в соответствии со ст. 27 Закона о Конституционном суде Президент Республики Узбекистан может участвовать в заседаниях Конституционного суда.

В пятых, Конституционный суд определяет в соответствии со ст.4 Закона о Конституционном суде соответствие Конституции Республики Узбекистан, указов, постановлений и распоряжений Президента Республики Узбекистан.

В шестых, Конституционный суд ежегодно представляет Президенту Республики Узбекистан информацию о состоянии конституционной законности в стране.

В-седьмых, Конституционный суд вправе давать толкование Конституции и законов Республики Узбекистан по запросу Президента Республики Узбекистан. 
В-восьмых, Президент присваивает квалификационные классы судьям Конституционного суда.

Взаимодействие Конституционного суда и органов исполнительной власти осуществляется в рамках:

1. Конституционного контроля за соответствием Конституции Республики Узбекистан актов, издаваемых правительством в управленческой сфере (постановлений Правительства, решений органов исполнительной власти на местах );

Кабинет Министров Республики Узбекистан в повседневной деятельности осуществляет конкретизацию правовых норм законов, придает им оперативный характер. Так, один из таких вопросов был связан с предоставлением инвалидам Отечественной войны и семьям, получающим пенсии по случаю потери кормильца за погибшего военнослужащего, льгот по оплате жилой площади и коммунальных услуг. Решением Конституционного суда Кабинету Министров Республики Узбекистан было предложено привести нормативные акты по данному вопросу в соответствие с Указом Президента Республики Узбекистан.

2. Конституционный суд призван обеспечивать реализацию Конституции Республики Узбекистан в актах органов исполнительной власти в сфере прав и свобод человека; (ст. 8 Закона о Конституционном суде).

3. Органы исполнительной власти предоставляют Конституционному суду нормативно-правовые акты, документы и разъяснения по всем интересующим их вопросам.

4. Кабинет Министров Республики Узбекистан вправе вносить вопросы на рассмотрение Конституционного суда, а премьер-министр Республики Узбекистан-участвовать в заседаниях Конституционного суда.

Правовые основы взаимоотношений Конституционного суда с палатами парламента определяется Конституцией, Конституционными законами «О Законодательной палате Олий Мажлиса Республики Узбекистан» и «О Сенате Олий Мажлиса Республики Узбекистан»22, Конституционным законом «О Конституционном суде Республики Узбекистан» и другими законами.

Во-первых, Олий Мажлис Республики Узбекистан определяет систему и полномочия органов судебной власти Республики Узбекистан, в том числе и полномочия Конституционного

Во-вторых, Конституционный суд Республики Узбекистан имеет право законодательной инициативы (ст. 83 Конституции). Рассмотрев вопрос «О внесении в Олий Мажлис Республики Узбекистан предложения об устра-

22 Ведомости Олий Мажлиса Республики Узбекистан 2002, № 12, ст. 213, 215. 
нении несоответствия между статьями 53, 54 и 257 Кодекса Республики Узбекистан об административной ответственности», Конституционный суд признал положения статей 53,54 , не соответствующими части второй статьи 257 Кодекса Республики Узбекистан об административной ответственности, и внес в порядке законодательной инициативы в парламент Узбекистана предложение об устранении этого несоответствия 23 . Так, основываясь на данном праве, Конституционный суд внес в Законодательную палату Олий Мажлиса Республики Узбекистан проект закона о внесении изменений и дополнений в ст. 74 Закона “Об акционерных обществах и защите прав акционеров" 24 . В результате было отменено положение Закона, предусматривавшее необходимость нотариального удостоверения доверенности на голосование на общем собрании акционеров от имени юридического лица.

В-третьих, в соответствии со ст. 109 Конституции Конституционный суд определяет соответствие Конституции Республики Узбекистан законов и постановлений палат Олий Мажлиса Республики Узбекистан.

В-четвертых, избрание на должность членов Конституционного суда Республики Узбекистан осуществляется верхней палатой парламента Сенатом.

В-пятых, субъектами обращения в Конституционный суд являются палаты парламента, Спикер Законодательной палаты и Председатель Сената Олий Мажлиса, группа депутатов - не менее одной четвертой части от общего числа депутатов Законодательной палаты и группа сенаторов - не менее одной четвертой части об общего числа членов Сената.

В шестых, в соответствии со ст. 95 Конституции Законодательная палата, Сенат могут быть распущены решением Президента Республики Узбекистан, принятым по согласованию с Конституционным судом, в случае возникновения в составе Законодательной палаты или Сената непреодолимых разногласий, ставящих под угрозу их нормальное функционирование, или неоднократного принятия ими решений, противоречащих Конституции, а также возникновения непреодолимых разногласий между Законодательной палатой и Сенатом, ставящих под угрозу нормальное функционирование Олий Мажлиса. В парламентской практике подобная ситуация еще не наблюдалась.

В седьмых, на заседаниях Законодательной палаты и Сената, а также на заседаниях их органов может участвовать председатель Конституционного суда, что происходит весьма часто на пленарных заседаниях палат, и практически всегда - на совместных заседаниях палат. В соответствии

23 См.: С. Хакимова, Становление и совершенствование конституционного правосудия в Республике Узбекистан РУз., Вестник Конституционного суда РУз. 2005, Выпуск 12, с. 95.

24 См.: Ведомости Олий Мажлиса РУз. 1996, № 5-6, ст. 61. 
со ст. 27 Конституционного закона «О Конституционном суде Республики Узбекистан» Спикер Законодательной палаты, его заместители, Председатель Сената, его заместители могут участвовать на заседаниях Конституционного суда. Однако, при этом представители законодательной власти не вмешиваются в деятельность Конституционного суда. Это обуславливается конституционным положением о том, что в своей деятельности судьи Конституционного суда независимы и подчиняются только Конституции. Председатель Конституционного суда принимает участие в заседаниях органов законодательной власти также, не вмешиваясь в их деятельность.

В восьмых, Конституционный суд даёт официальное толкование норм Конституции и законов, принятых органом законодательной власти. Толкование норм Конституции и законов осуществляется в случае обнаружения неясностей в них, неправильностей или противоречивой практики их применения. В процессе толкования не допускается внесение поправок, дополнений в те нормы, по которым даётся толкование. Когда в Конституционном суде рассматривается дело о толковании норм Конституции и законов, представитель органа законодательной власти приглашается на заседание Конституционного суда в качестве стороны.

Взаимодействие между Конституционного суда и иными судами строятся на принципе невмешательства в деятельность друг друга. В Конституции Узбекистана закреплено положение, предусматривающее, что Конституционный суд рассматривает дела о конституционности актов только законодательной и исполнительной власти ${ }^{25}$.

Отличие Конституционного суда от иных судов состоят в следующем: Во-первых, Конституционный суд Республики Узбекистан также как и конституционные суды других стран является не только судебном органом, но и высшим конституционным органом, полномочия Конституционного суда устанавливаются самой Конституцией. Полномочия других судебных органов установлены не Конституцией, а законами.

Во-вторых, правовое положение Конституционного суда определяется отдельным законом - Конституционным законом «О Конституционном

25 В некоторых странах СНГ Конституционный суд рассматривает дела о конституционности актов также и судебной власти. Так, например, в соответствии со ст. 116 Конституции Республики Беларусь Конституционный суд дает заключения о соответствии актов Верховного суда, Высшего хозяйственного суда Конституции, международно-правовым актам, ратифицированным Республикой Беларусь, законам, декретам и указам. А в соответствии со ст. 130 Конституции Азербайджанской Республики Конституционный суд решает вопросы о соответствии в предусмотренных в законе случаях решений Верховного суда Конституции и законам (см.: Конституции государств-участников СНГ, Москва 2001). 
суде Республики Узбекистан», правовое положение других судов определяется Законом «О судах».

B-третьих, Конституционный суд рассматривает дела не в порядке процедуры, установленной процессуальными кодексами Республики Узбекистан, которыми руководствуются другие суды, а по тем правилам и нормам конституционного судопроизводства, которые закреплены в Регламенте Конституционного суда. Этот Регламент утвержден самим Конституционным судом 26.

В-четвертых, этическое поведение судей других судов регулируется в настоящее время правилами этического поведения судей, утвержденными Высшим судейским советом Республики Узбекистан, а этика судей Конституционного суда регулируется Кодексом чести судьи Конституционного суда, утвержденным самим Конституционным судом.

Вопрос взаимоотношений между Конституционным судом и другими судами тесно связан с вопросом их общности и различия между ними. Так, Конституционный суд рассматривает дела о конституционности нормативно-правовых актов. Суды по гражданским делам и хозяйственные суды ранее были вправе рассматривать дела о законности нормативно-правовых актов. В соответствии со ст. 12 Гражданского кодекса Республики Узбекистан 27 акт государственного органа или органа самоуправления граждан, не соответствующий законодательству и нарушающий гражданские права и охраняемые законом интересы гражданина или юридического лица, может быть признан судом недействительным.

До 2002 года Закон «О Конституционном суде Республики Узбекистан» предусматривал, что судья Конституционного суда не может быть привлечен к уголовной ответственности, арестован или подвергнут мерам административного взыскания, налагаемым в судебном порядке, без согласия Олий Мажлиса, а в период между сессиями - без согласия Совета (Кенгаша) Олий Мажлиса. Такая норма противоречила конституционному принципу разделения властей. Кроме того Закон «О судах» предусматривал, что судья не может быть привлечен к уголовной ответственности, заключен под стражу без согласия соответственно Пленума Верховного суда или Пленума Высшего хозяйственного суда. В этой норме как раз был учтен принцип разделения властей. Поэтому в Закон «О Конституционном суде Республики Узбекистан» была внесена поправка, предусматривающая, что судья Конституционного суда

2617 апреля 2015 г. решением Конституционного суда утвержден Регламент Конституционного суда Республики Узбекистан (См.: Конституичионный суд Республики Узбекистан (Сборник документов), Ташкент 2015).

27 См.: Кодексы Республики Узбекистан. Сборник, Ташкент 2016, с. 1119. 
не может быть привлечен к уголовной и административной ответственности, а также заключен под стражу без согласия самого Конституционного суда.

В соответствии со ст. 83 Конституции и Конституционный суд, и Верховный суд имеют право законодательной инициативы, при реализации которого взаимодействуют друг с другом. Так, в соответствии с Указом Президента Республики Узбекистан «Об организационных мерах по дальнейшему совершенствованию деятельности судов» от 30 ноября 2012 года для судей судов общей юрисдикции и хозяйственных судов был установлен минимальный возраст - 30 лет. В настоящее время повышен возрастной ценз кандидата в судьи с 30 до 35 лет.

В соответствии с указом Верховным судом был подготовлен проект закона, предусматривающий изменения и дополнения в соответствующие законы. В ходе обсуждения данного проекта в Конституционном суде было предложено такой возраст применить и в отношении судей Конституционного суда. Верховный суд учел мнение Конституционного суда по этому вопросу и внес его предложение в проект закона. После принятия дополнения в Закон «О Конституционном суде Республики Узбекистан» судьей Конституционного суда может быть избран гражданин Республики Узбекистан не моложе тридцати пяти. Предельный возраст пребывания в должности судьи Конституционного суда ныне составляет как правило семьдесят лет.

В пятых, Верховный суд Республики Узбекистан в лице его председателя входит в число субъектов, обладающих правом внесения вопросов в Конституционный суд (ст. 83 Конституции). К сожалению, Верховный суд страны до настоящего времени не использовал это свое право на практике. Однако, он по своему статусу и характеру выполняемых функций относится к числу тех органов, с которыми Конституционный суд взаимодействует особенно тесно. По многим вопросам, принятым на рассмотрение, Конституционный суд просит председателя Верховного суда дать по ним заключение или иным образом выразить свою позицию.

B-шестых, в соответствии со ст. 4 Закона Республики Узбекистан «О Конституционном суде Республики Узбекистан», Конституционный суд может рассмотреть обращение Верховного суда Республики Узбекистан, инициированное судами, о соответствии Конституции Республики Узбекистан нормативно-правовых актов, подлежащих применению в конкретном деле.

Пленум Верховного суда Республики Узбекистан принимает постановления нормативного характера, но они остаются вне конституционного контроля, что требует своего законодательного решения. 
В-седьмых, Конституционный суд при осуществлении конституционного судопроизводства воздерживается от установления и использования фактических обстоятельств во всех случаях, когда это входит в компетенцию других судов.

В-восьмых, Конституционный суд избирается Сенатом по представлению Президента из числа лиц, рекомендованных Высшим судейским советом Республики Узбекистан (ст.5 Закона о Конституционном суде Республики Узбекистан).

В-девятых, председатель Верховного суда и председатель Высшего судейского совета Республики Узбекистан могут участвовать в заседаниях Конституционного суда Республики Узбекистан и излагать свою позицию по всем рассматриваемым вопросам.

\section{Конституционный суд и другие органы}

В Республике Узбекистан вместе с судебной существует и развивается внесудебная защита прав человека, которая осуществляется Уполномоченным Олий Мажлиса Республики Узбекистан по правам человека (омбудсманом) и Национальным центром Республики Узбекистан по правам человека. Их основными задачами является содействие имплементации международных стандартов защиты прав и свобод граждан, провозглашенных Конституцией и законами Республики Узбекистан, а также мониторинг ситуации в сфере выполнения международных обязательств Республики Узбекистан в сфере прав человека.

2 декабря 1998 года между Конституционным судом и Уполномоченным Олий Мажлиса по правам человека было заключено соглашение «О сотрудничестве в сфере обеспечения верховенства Конституции Республики Узбекистан и защиты прав и свобод человека». В основу данного соглашения легли такие принципы как верховенство Конституции и законов, независимость этих органов, координация их деятельности по обеспечению прав и свобод граждан. Сотрудничество Конституционного суда с институтом омбудсмана укрепилось с принятием изменений и дополнений в Конституцию Республики Узбекистан и Закон «Об Уполномоченном Олий Мажлиса Республики Узбекистан по правам человека» от 29 августа 2017 г. 28 посредством наделения его правом внесения вопросов на рассмотрение в Конституционный суд Узбекистана и участия в заседаниях, а также получения права

28 См.: Собрание законодательства Республики Узбекистан 2004, № 38-39, ст. 420; 2017 г., № 35, ст. 916. 
Национального центра Республики Узбекистан на участие в заседаниях Конституционного суда на основании Постановления Президента Республики Узбекистан от 10 декабря 2018 г. ${ }^{29}$

Так, например в настоящее время эти институты взаимодействуют в следующих направлениях:

1) Руководители Конституционного суда, Национального центра по правам человека и Омбудсман приглашают друг друга на мероприятия и заседания, затрагивающие права и свободы человека. Так, Омбудсман и руководитель Национального центра по правам человека лично принимают участие в заседаниях Конституционного суда, где рассматриваются конкретные дела. Представители Конституционного суда принимают участие в мероприятиях Омбудсмана и Национального центра по правам человека.

2) Сотрудничество осуществляется также в сфере подготовки предложений по совершенствованию законодательства. Так, проекты законов, подготовленные Омбудсманом и Национальным центром по правам человека изучаются специалистами Конституционного суда и даются по ним конкретные предложения. Так, Конституционным судом было одобрено предложение омбудсмана о включении его в число субъектов, имеющих право вносить вопросы для рассмотрения на заседаниях Конституционного суда.

3) В целях научной проработки некоторых правовых проблем, изложенных в обращениях граждан, также оказания квалифицированной помощи Уполномоченному два работника аппарата Конституционного суда являются членами экспертного совета на общественных началах при Уполномоченном Олий Мажлиса по правам человека.

4) В рамках сотрудничества между Конституционным судом, Омбудсманом и Национальным центром по правам человека осуществляется регулярный обмен информацией. Так, Конституционный суд направляет им материалы заседания Конституционного суда, материалы нормативноправового характера, а также периодическое издание «Вестник Конституционного суда Республики Узбекистан». Омбудсман направляет Конституционному суду свои ежегодные отчеты и другие материалы.

5) Конституционный суд, Омбудсман и Национальный центр по правам человека совместно подготавливают и проводят научно-практические конференции, семинары с участием представителей государственных органов, негосударственных организаций и граждан по определенным проблемам защиты прав и свобод граждан.

29 См: Национальная база данных законодательства, 11.12.2018 г., № 07/18/4056/2294. 
Практика деятельности Конституционного суда Республики Узбекистан показывает, что к нему обращаются за толкованием норм законов и органы, не имеющие на то право согласно Конституции и Закону «О Конституционном суде». Так, Институт мониторинга действующего законодательства при Президенте Республики Узбекистан ранее обращался в Конституционный суд по двум вопросам:

1) о толковании ст. 118 Трудового кодекса о возможности установления сокращенной продолжительности рабочего времени для отдельных категорий работников;

2) о проверке конституционности норм, регулирующих порядок назначения и выплаты пособия в связи с уходом за заболевшим членом семьи. Оба вопроса были признаны судьями Конституционного суда заслуживающими рассмотрения на судебном заседании. Их правильное разрешение позволило существенно расширить права работников на сокращенную продолжительность рабочего времени и получение пособия в связи с уходом за заболевшим членом семьи.

Благотворительный фонд «Махалла» обратился к суду с просьбой дать толкование ст. 105 Конституции об органах самоуправления граждан. По поступающим от граждан копиям решений хокимиятов (местные органы управления) изучался вопрос о порядке изъятия земель и зданий, находившихся в пользовании юридических лиц и граждан, порядок приватизации квартир, индексации вкладов, хранящихся в народном банке и др.

Согласно ст. 25 Конституционного закона «О Конституционном суде Республики Узбекистан» правом внесения на рассмотрение Конституционного суда вопросов обладает Генеральный прокурор Республики Узбекистан. Он вправе участвовать в заседании суда, излагать свою позицию по всем рассматриваемым вопросам, а также возбуждать уголовное дело в отношении судьи Конституционного суда с его согласия.

\section{Компетенция и основные полномочия Конституционного суда в области защиты конституционных прав и свобод человека}

Согласно Конституции Узбекистана Конституционный суд входит в судебную систему государства (ст. 107). Являясь особым судебным органом, он призван обеспечивать верховенство и прямое действие Конституции, выступать на одном (общегосударственном) уровне с высшим органом представительной и исполнительной ветвями власти. Особый статус Конституционного суда подчеркивается и тем, что полномочия Конституционного суда закреплены на конституционном уровне. Определение компетенции Кон- 
ституционного суда непосредственно в самой Конституции есть гарантия против посягательства на его независимость.

Предмет конституционного контроля, осуществляемого Конституционным судом в соответствии с полномочиями, закрепленными в ст. 4 Конституционного закона «О Конституционном суде Республики Узбекистан» составляет:

- определение соответствия Конституции Республики Узбекистан законов Республики Узбекистан и постановлений палат Олий Мажлиса Республики Узбекистан, указов, постановлений и распоряжений Президента Республики Узбекистан, постановлений правительства, решений местных органов государственной власти, межгосударственных договорных и иных обязательств Республики Узбекистан;

- определение соответствия Конституции Республики Узбекистан конституционных законов Республики Узбекистан, законов Республики Узбекистан о ратификации международных договоров Республики Узбекистан до их подписания Президентом Республики Узбекистан;

- вынесение заключения о соответствии Конституции Республики Каракалпакстан Конституции Республики Узбекистан, законов Республики Каракалпакстан - законам Республики Узбекистан;

- осуществление толкования норм Конституции и законов Республики Узбекистан;

- рассмотрение обращения Верховного суда Республики Узбекистан, инициированного судами, о соответствии Конституции Республики Узбекистан нормативно-правовых актов, подлежащих применению в конкретном деле;

- ежегодное представление палатам Олий Мажлиса Республики Узбекистан и Президенту Республики Узбекистан информации о состоянии конституционной законности в стране по результатам обобщения практики конституционного судопроизводства.

- рассмотрение других дел, отнесенных к его компетенции Конституцией и законами Республики Узбекистан.

Таким образом, предметом контрольной деятельности Конституционного суда является круг отношений, связанных с обеспечением верховенства и прямого действия Конституции, а также охраны основных конституционных принципов и ценностей, провозглашенных и гарантированных Основным законом. 


\section{Абстрактный контроль и предварительный контроль правовых норм}

В Конституционном суде постоянно идет процесс изучения принимаемых законов и нормативных актов, в ходе которого выявляются их соответствие Конституции, наличие в законодательстве норм, противоречащих друг другу.

Анализ решений, принятых Конституционным судом Республики Узбекистан, свидетельствует о том, что в большинстве случаев они были направлены на обеспечение прав и свобод граждан, гарантированных Конституцией ${ }^{30}$. Например, в деле о проверке конституционности п. 17 ч. 5 Положения о порядке назначения и выплаты пособий по государственному социальному страхованию Конституционный суд пришел к выводу, что норма этого Положения, ограничивающая права работника, находящегося в очередном или дополнительном трудовом отпуске, на получение пособия по уходу за заболевшим членом семьи, не соответствует Конституции. В результате законодательство было приведено в соответствие с Конституцией для обеспечения её верховенства.

Определяя соответствие Основному закону страны того или иного закона или его нормы, Конституционный суд тем самым защищает права и свободы граждан. Так, ст. 536 УПК Республики Узбекистан было определено, что условно-досрочное освобождение от наказания и замена не отбытой части наказания более мягким применяется судьей по представлению администрации учреждения по исполнению наказания. В этой норме не предусматривалась возможность обращения осужденных непосредственно в суд с просьбой об условно-досрочном освобождении от наказания и замене не отбытой части наказания более мягким. Изучив вопрос, Конституционный суд решил, что такая практика не соответствует ст. 44 Конституции Республики Узбекистан, в соответствии с которой каждому гарантируется судебная защита его прав и свобод. В соответствии с постановлением Конституционного суда Олий Мажлис Республики Узбекистан принял Закон о внесении дополнения в эту статью, предусматривающего право осужденного обращаться в суд с просьбой об условно-досрочном освобождении от наказания и замене не отбытой части наказания более мягким.

Посредством реализации своего полномочия осуществлять толкование норм Конституции и законов Конституционный суд Республики Узбекистан разрешает неясности, устраняет неправильную или противоречивую практику применения этих норм должностными лицами и государственными

30 Материалы подготовлены на основании данных, размещенных на вебсайте Конституционного суда Республики Узбекистан (www.ksu.uz). 
органами всех трех ветвей власти. Используя указанное полномочие, рассматривая дело о толковании ст. 59 Налогового кодекса (НК), Конституционный суд принял решение о том, что льготы, предусмотренные ст. 59 НК Республики Узбекистан, распространяются также и на доходы, полученные по дивидендам и процентам. Такое толкование нормы закона устранило его неправильное применение.

Как видим, Конституционный суд в ходе выявления сути и содержания норм актов законодательства осуществляет выработку определенных своих правовых позиций. Для правильной правоприменительной практики Конституционному суду важно уяснить содержательный смысл рассматриваемого акта, опираясь при этом на фундаментальные конституционные положения, «дух» Основного закона, тем самым и дать юридико-техническую оценку посредством своего заключения или толкования. В рассматриваемом аспекте заключения и толкования Конституционного Суда представляют собой важный источник права ${ }^{31}$.

Абстрактный конституционный контроль означает осуществление надзора за соответствием норм законодательства основным принципам,

31 Так, например, в Конституционный суд Республики Узбекистан обратился гражданин С. Якубжанов с просьбой дать толкование порядка осуществления аудиозаписи (звукозаписи) при разбирательстве дела в судебном заседании.

В Кодексе об административном судопроизводстве и Экономическом процессуальном кодексе Республики Узбекистан законодательно закрепляется, что суд обсудив ходатайство участников судопроизводства может разрешить или не разрешить проводить звукозапись, то есть если ходатайство участника судопроизводства не будет удовлетворено судом, то он не вправе осуществлять звукозапись, тогда как любой присутствующий в судебном заседании может осуществлять звукозапись, вести стенограмму, делать письменные заметки без разрешения суда.

Фотосъемка, видеозапись, а также трансляция судебного заседания по радио и телевидению допускаются с разрешения суда, рассматривающего дело».

Таким образом, вопреки принципу гласности судебного разбирательства, провозглашенного в Конституции Республики Узбекистан (ст. 113 Конституции Республики Узбекистан), ограничивается право участников судопроизводства, определив их возможность осуществления звукозаписи лишь по разрешению суда, тогда как другие лица, присутствующие в судебном разбирательстве, наделяются правом на осуществление звукозаписи без разрешения суда.

В связи с этим Решением Конституционного суда Республики Узбекистан от 14 ноября 2018 г. предлагалось внести в Законодательную палату Олий Мажлиса Республики Узбекистан в порядке законодательной инициативы проект закона Республики Узбекистан «О внесении изменений и дополнений в Гражданский процессуальный кодекс Республики Узбекистан, Экономический процессуальный кодекс Республики Узбекистан и Кодекс Республики Узбекистан об административном судопроизводстве», предусматривающий единообразное определение порядка осуществления звукозаписи в судебном заседании во всех трех указанных кодексах, а также устранение ущемления права участника судебного заседания проводить звукозапись. 
духу и идее Конституции. Это своего рода обеспечение конституционного императива, имеющего целью полную реализацию норм Конституции, индикатор претворения в законодательстве принципов и правил, закрепленных в Основном законе. Объектом конституционного контроля здесь выступает весь массив законодательства. Субъекты, имеющие право инициировать конституционное судопроизводства, могут поставить вопрос о проверке конституционности любого законодательного акта. Абстрактный контроль заключается в том, что юрисдикция Конституционного суда охватывает весь спектр нормативно-правовых актов страны.

\section{Проверка (предварительный контроль) конституционности законов Республики Узбекистан о ратификации международных договоров Республики Узбекистан до их подписания Президентом Республики Узбекистан}

В законодательстве Узбекистана прямо не говорится о предварительном конституционном нормоконтроле, фактически Конституционный суд наделен правом участия в законотворческом процессе, поскольку он входит в круг субъектов права законодательной инициативы. На практике фактически многие законопроекты направляются в Конституционный суд для отзыва.

Здесь следует иметь в виду, что объектом контроля выступает не международный договор как таковой, а лишь закон о его ратификации (точнее законопроект, поскольку он еще не подписан Президентом страны), т.е. акт о выражении обязательности международного договора, каковым является закон о ратификации. При рассмотрении вопроса о том, может ли являться предметом рассмотрения в Конституционном суде международный договор, следует отметить, что проверка конституционности таких актов повлияет на юридическую силу самого международного договора. Так, если закон о ратификации будет признан не соответствующим Конституции, закон о его ратификации не вступит в силу. Однако проверка конституционности закона о ратификации международного договора не означает проверку конституционности самого международного договора.

К числу преимуществ предварительного (превентивного) контроля можно отнести то, что эта форма контроля:

1. Предварительно уточняет вопрос о конституционности нормативного акта, что укрепляет надежность и стабильность правовой системы.

2. Способствует наиболее результативной работе законодателя и повышению его авторитета. 
3. Предотвращает сложности, которого могут возникнуть если действующий в течение ряда лет закон или его отдельное положение признано неконституционным;

4. До ратификации международного договора и принятия государством международных обязательств обеспечивает окончательное и авторитетное решение по вопросу о конституционности этих обязательств.

Конкретный контроль конституционности законов и иных норм правовых актов, применяемых судами Республики Узбекистан, которые подлежат применению при рассмотрении конкретного дела (ст. 4, п. 5 Закона о Конституционном суде).

Контроль за конституционностью нормативно-правовых актов, применяемых судами, служит обеспечению верховенства Конституции в судопроизводстве, а их признание не соответствующими Основному закону может стать основанием для отмены в установленном порядке не только положений нормативных актов, но и судебных решений, основанных на акте, признанном неконституционным.

Толкование Конституции и законов Республики Узбекистан (ст. 4, п. 4 Закона о Конституционном суде). Конституционный суд осуществляет официальное толкование Конституции. Особая природа решений Конституционного суда о толковании конституционных положений и норм законов выражается в том, что эти акты распространяются на неограниченное число случаев и имеют общеобязательное значение. В актах толкования закрепляются правовые позиции, разъясняющие, уточняющие действительный смысл толкуемых положений. Хотя акт толкования не может вносить изменения, дополнения и поправки в толкуемый акт, он осуществляет трактовку, интерпретацию сути и смысла толкуемой нормы, обеспечивая единообразное понимание и применение толкуемого закона. Толкование Конституционного суда может стать юридическим основанием для отмены или изменения в установленном порядке нормативно-правовых актов.

Президент и не только может обратиться в Конституционный суд с предложением проверки соответствия Конституции страны любого проекта нормативно-правового акта, в т.ч. перед подписанием закона или заключением международного договора. Процедура - стандартная, как рассмотрения любого иного обращения органов и должностных лиц, обладающих указанным правом.

Кроме того, в соответствии с компетенцией Конституционного суда им осуществляется так называемый последующий конституционный контроль. Участие Конституционного суда в нормоконтроле осуществляется преимущественно посредством разрешения дел о конституционности нормативноправового акта и официального толкования норм Конституции. 


\section{Процедура контроля правовых норм}

Будучи самостоятельной процессуальной формой функционирования Конституционного суда Республики Узбекистан, конституционное судопроизводство представляет собой совокупность урегулированных процессуальными конституционными нормами процедур и правоотношений, складывающихся между Конституционным судом и иными участниками конституционного судопроизводства по разбирательству конституционно-правовых вопросов и споров о компетенции в целях достижения поставленных перед ним целей и задач. Именно установление надлежащих юридических процедур и правил конституционного судопроизводства способствует обеспечению правильного понимания и применения предписаний материальных конституционных норм, защите прав, свобод и законных интересов субъектов конституционного судопроизводства и в конечном счете вынесению Конституционным судом по результатам рассмотрения конкретного дела всестороннего и объективного итогового решения.

Конституционное судопроизводство представляет собой отдельный, самостоятельный, наряду с гражданским, уголовным, хозяйственным и административным, вид судопроизводства. Установление для Конституционного суда особого порядка осуществления судебной власти обусловлено отличием конституционно-правового положения Конституционного суда от правового положения других судебных органов в части компетенции, организации, характера рассматриваемых дел и принимаемых решений, их юридической силы и механизма исполнения. Осуществление Конституционным судом исключительной функции - контроля за конституционностью нормативных актов в государстве предопределяет и особую процедуру реализации судебной власти - конституционное судопроизводство.

Организационной формой осуществления конституционного судопроизводства являются судебные заседания. Следует особо отметить, что заседание Конституционного суда Республики Узбекистан проводится с соблюдением правил и процедур, установленных Регламентом. Заседания Конституционного суда созываются председателем, в его отсутствие - заместителем председателя, а при отсутствии председателя Конституционного суда и его заместителя или невозможности выполнения ими своих обязанностей - старшим по возрасту судьей Конституционного суда. Конституционный суд при разрешении дел руководствуется исключительно Конституцией Республики Узбекистан.

В соответствии со ст. 18 Регламента Констутуционного суда Республики Узбекистан от 17 апреля 2015 г. сторонами в конституционном судопроизводстве являются государственный орган или должностное лицо, 
внесшее вопрос на рассмотрение Конституционного суда; государственный орган или должностное лицо, принявшее (издавшее) нормативно-правовой акт, конституционность которого подлежит проверке; государственный орган, к компетенции которого относятся вопросы, содержащиеся в межгосударственном договорном или ином обязательстве Республики Узбекистан; палаты Олий Мажлиса Республики Узбекистан, по делам о толковании норм Конституции и законов Республики Узбекистан и даче согласия Президенту Республики Узбекистан на принятие решения о роспуске Законодательной палаты, Сената Олий Мажлиса Республики Узбекистан; Жокаргы Кенес Республики Каракалпакстан по делам о даче заключения о соответствии Конституции Республики Каракалпакстан Конституции Республики Узбекистан, законов Республики Каракалпакстан - законам Республики Узбекистан.

При внесении вопроса на рассмотрение Конституционного суда по инициативе судей Конституционного суда стороной является государственный орган, юридическое или физическое лицо, обращение которого явилось поводом к внесению вопроса.

Сторона вправе иметь одного или нескольких представителей, которые представляют ее интересы в Конституционном суде. При внесении вопроса на рассмотрение Конституционного суда группой депутатов или сенаторов, они должны назначить одного или нескольких представителей.

В качестве представителя стороны могут выступать адвокаты, специалисты и другие лица на основании доверенности, выданной стороной с указанием их полномочий.

Представителями сторон в Конституционном суде по должности могут выступать руководители государственных органов и юридических лиц, указанных в части первой и второй настоящей статьи. Представители сторон по должности представляют интересы стороны без доверенности.

В ст. 19 Регламента Констутуционного суда Республики Узбекистан подчеркивается, что стороны и их представители вправе знакомиться со всеми материалами дела; излагать свою позицию по делу; представлять письменные отзывы; заявлять ходатайства, в том числе об отводе судьи, назначении экспертизы, вызове в суд свидетелей, экспертов и специалистов; предлагать кандидатуры экспертов и специалистов; задавать вопросы участникам конституционного судопроизводства.

Конституционный суд принимает решения только по конкретным рассматриваемым вопросам, конституционность которых подвергается сомнению. Он может, проверив конституционность нормативного акта, одновременно вынести решение также и в отношении нормативных актов, основанных на проверенном нормативном акте либо воспроизводящих его положения, хотя 
о них и не упоминалось во вносимом на рассмотрение Конституционного суда вопросе. Решение Конституционного суда принимается открытым голосованием. Решение считается принятым, если за него проголосовало большинство от присутствующих на заседании судей.

Конституционный суд должен вынести решение по рассматриваемому вопросу не позднее 3-х месяцев с момента получения соответствующего материала (ст. 26 Конституционного закона о Конституционном суде). Конституционный суд принимает решение только по конкретно рассматриваемым вопросам. Вместе с этим, Конституционный суд вправе, проверив конституционность нормативно-правовых актов, одновременно вынести решение также и в отношении других нормативно-правовых актов, основанных на проверенном нормативно-правовом акте либо воспроизводящих его положения, хотя о них и не упоминалось во вносимом на рассмотрение Конституционного суда вопросе.

Решения Конституционного суда вступают в силу с момента опубликования. Они окончательны и обжалованию не подлежат, действуют непосредственно и не требуют подтверждения другими органами и должностными лицами. Именно такой порядок вступления в силу решения Конституционного суда обеспечивает самостоятельное и независимое осуществление им судебной власти посредством конституционного судопроизводства.

\section{Дальнейшее совершенствование деятельности конституционном суда Республики Узбекистан по защите прав и свобод человека}

\section{Формирование и внедрение института конституционной жалобы физических и юридических лиц по поводу нарушения их конституционных прав}

Право на обращение граждан является одним из важных факторов обеспечения и эффективной защиты прав человека, предусмотренное в соответствии со ст. 35 Конституции Республики Узбекистан. В законодательстве Узбекистана этому вопросу отведено особое место и определены принципы его осуществления. Государство осуществляет в этом направлении поэтапное реформирование действующего законодательства. В настоящее время принят и действует ряд законов, которые совершенствуются.

Одним из таких правовых актов является Закон Республики Узбекистан «Об обращениях физических и юридических лиц» ${ }^{32}$, принятый в новой

32 См.: Собрание законодательства Республики Узбекистан 2014, № 49, ст. 578. 
редакции 11 сентября 2017 г. Данный Закон усовершенствовал порядок подачи обращений в государственные органы, а также их рассмотрения. Предусмотрена ответственность за нарушения в этой сфере, конкретизирован порядок обращения в государственные органы, к должностным лицам.

Этим законом определены такие важные положения, как: порядок подачи обращений физическими и юридическими лицами; порядок рассмотрения обращений государственными органами; права физических и юридических лиц и обязанности государственных органов при рассмотрении обращений. Кроме этого в законе определены формы, виды обращений, требования, предъявляемые к ним, а также закреплены гарантии приема физических лиц и представителей юридических лиц. В данном нормативно-правовом акте нашли свое отражение нормы, касающиеся порядка, сроков подачи и рассмотрения обращений, основания для оставления обращений без рассмотрения, права физических и юридических лиц при рассмотрении обращений и обязанности государственных органов, возмещение материального ущерба и компенсация морального вреда, ответственность за нарушение законодательства об обращениях.

Одним из основных изменений, связанных с научно-техническим прогрессом и современными информационными технологиями, стало закрепление права на обращения в электронной форме. Теперь физические и юридические лица могут обратиться в установленном порядке в соответствующие ведомства либо к должностным лицам, используя информационнокоммуникационные технологии.

Несмотря на то, что Конституционным законом «О Конституционном суде Республики Узбекистан» не предусмотрено рассмотрение обращений граждан о неконституционности того или иного закона, а также обращений о толковании Конституции, обращения физических и юридических лиц могут являться основанием для рассмотрения вопроса в Конституционном суде в том случае, если этот вопрос будет внесен на его рассмотрение по инициативе не менее трёх судей Конституционного суда.

Судья Конституционного суда, изучающий обращение гражданина, которое содержит вопросы, относящиеся к компетенции Конституционного суда, может:

- вызвать гражданина, направившего обращение, для внесения уточнения в рассматриваемый вопрос и сбора дополнительного материала;

- анализировать практику исполнения законодательного акта, соответствие которого Конституции ставится под сомнение;

- пригласить представителей уполномоченной организации, обеспечивающей исполнение законодательного акта, соответствие которого Конституции ставится под сомнение; 
- требовать дополнительные сведения по рассматриваемому делу от соответствующих органов и должностных лиц.

Заключение об изученном обращении готовится судьей Конституционного суда для внесения на заседание Конституционного суда и представляется председателю Конституционного суда или его заместителю.

Судьи Конституционного суда по своей инициативе на основе изучения поступивших в суд обращений и материалов могут внести на рассмотрение суда вопросы, касающиеся защиты прав и свобод человека.

В соответствии со ст. 44 Конституции Республики Узбекистан каждому гарантируется судебная защита его прав и свобод; незаконные решения и действия (или бездействие) органов государственной власти, общественных объединений и должностных лиц могут быть обжалованы в суд. В этом механизме защиты прав и свобод человека и гражданина Конституционный суд занимает особое место. В отличие от судов общей юрисдикции и хозяйственных ему отведена решающая роль в обеспечении верховенства Конституции и законов ${ }^{33}$.

Ст. 4 Конституционного закона «О Конституционном суде Республики Узбекистан» содержит перечень вопросов, которые рассматривает только данный суд. Кроме того, он отличается от судов общей юрисдикции, что законодатель ограничивает круг субъектов, имеющих право вносить вопросы на рассмотрение этого суда.

Конституционный суд определяет соответствие Конституции Республики Узбекистан законов и иных правовых актов, а следовательно, защищает граждан от нарушений их прав и свобод неконституционным законом, который применен или подлежал применению.

Защита прав и свобод граждан также будет осуществлена, если Конституционный суд, используя свое право законодательной инициативы, обратится в законодательный орган с предложением о внесении изменений в законодательные акты и эта инициатива будет поддержана.

Из смысла ст. 4 Конституционного закона «О Конституционном суде Республики Узбекистан» вытекает, что граждане или лица без гражданства могут инициировать обращение органа или лица, обладающего правом обратиться с соответствующим запросом в Конституционный суд в случаях, если они:

a) считают, что их права нарушены законом Республики Узбекистан или иным актом, принятым Олий Мажлисом, указом Президента Узбекистана, постановлением правительства или местного органа государ-

33 См.: Н. Кариева, Конституциионый суд и обращения граждан, «Вестник Конституционного суда РУз.» 2004, Выпуск 10, с. 171-174. 
ственной власти, международным договором либо иным обязательством Республики Узбекистан, не соответствующим ее Конституции;

б) полагают, что Конституция Республики Каракалпакстан или закон Республики Каракалпакстан не соответствует Конституции Республики Узбекистан или закону Республики Узбекистан;

в) просят дать толкование норм Конституции и законов Республики Узбекистан ${ }^{34}$.

Согласно ст. 25 Конституционного закона «О Конституционном суде Республики Узбекистан» правом внесения на рассмотрение Конституционного суда вопросов обладают только палаты Олий Мажлиса Республики Узбекистан; Президент Республики Узбекистан; Кабинет Министров Республики Узбекистан; Уполномоченный Олий Мажлиса Республики Узбекистан по правам человека (омбудсман); Жокаргы Кенес Республики Каракалпакстан; группа депутатов - не менее одной четвертой части от общего числа депутатов Законодательной палаты Олий Мажлиса Республики Узбекистан; группа сенаторов - не менее одной четвертой части от общего числа членов Сената Олий Мажлиса Республики Узбекистан; Верховный суд Республики Узбекистан; Генеральный прокурор Республики Узбекистан.

Вопрос на рассмотрение Конституционного суда Республики Узбекистан может быть внесен и по инициативе не менее трех судей Конституционного суда. Таким образом, норма этой статьи закона строго ограничивает круг субъектов, имеющих право внести в Конституционный суд тот или иной

34 Так было, например, с делами о толковании абзаца пятого части первой статьи 6 Закона Республики Узбекистан «Об адвокатуре», инициированном в связи с заявлением адвоката Х. Нурмухамедова; о толковании статьи 59 Налогового кодекса Республики Узбекистан, инициированном в связи с заявлением гражданина С. Муратходжаева; о толковании части четвертой статьи 62 Закона Республики Узбекистан «О судах», рассмотренном после обращения в суд адвоката К. Музаффарова, и другими. //См.: Н. Кариева, Конституциионный суд и обращения граждан, «Вестник Конституционного суда РУз.» 2004, Выпуск 10, с. 173.

Так, в Конституционный суд обратился индивидуальный предприниматель В. Фролов с жалобой на неправомерное лишение его льгот, предусмотренных частью второй статьи 16 Закона Республики Узбекистан «О гарантиях свободы предпринимательской деятельности». Речь шла о неправильном понимании и применении нормы закона налоговыми и финансовыми органами. Изучив обстоятельства дела и соответствующие доводы Министерства финансов и Государственного налогового комитета Узбекистана, трое судей Конституционного суда выступили с инициативой внесения этого вопроса на рассмотрение суда. В результате рассмотрения суд пришел к выводу о необходимости дать толкование этой нормы в связи с тем, что вышеуказанные органы по-своему трактуют ее, что влечет наступление определенных правовых последствий не только для В.Фролова, но и для других субъектов малого и частного предпринимательства. С. Хакимова, Становление и совершенствование конституционного правосудия в Республике Узбекистан РУз., «Вестник Конституционного суда РУз.» 2005, Выпуск 12, с. 94. 
вопрос, входящий в компетенцию последнего. Поэтому обращения граждан сами по себе непосредственно не могут возбуждать конституционное производство. Иными словами, обращения граждан и право внесения вопросов в Конституционный суд - разные понятия. Граждане не имеют полномочия вносить на рассмотрение Конституционного суда вопросов, а значит, поданное им обращение будет рассмотрено в порядке, предусмотренном Законом Республики Узбекистан «Об обращениях физических и юридических лиц», а не порядке конституционного судопроизводства. То есть рассмотрение обращений граждан не может напрямую повлечь вынесение решения Конституционным судом, вынесенным в процессуальном порядке.

В связи с этим Конституционным судом разработано и принято «Положение о порядке рассмотрения обращений граждан в Конституционный суд Республики Узбекистан», в котором регламентированы механизмы, позволяющие гражданам реализовать конституционное право на защиту своих прав и законных интересов.

Заявлений, жалоб, предложений поступает в Конституционный суд очень много. Если в 2017 году их было около 432, то в 2018 году - 708. Как видим, количество обращений в Конституционный суд по вопросам нарушения конституционных прав и свобод имеет тенденцию к увеличению. Это означает, что все большее число граждан страны осваивают правовую систему и начинают ее активно использовать.

\section{Правовой характер решений Конституционного суда и их правовая сила}

В соответствии со ст. 31 Закона «О Конституционном суде Республики Узбекистан〉 Конституционный суд принимает решения только по конкретным рассматриваемым вопросам, конституционность которых подвергается сомнению. Конституционный суд может, проверив конституционность нормативно-правового акта, одновременно вынести решение также и в отношении нормативно-правовых актов, основанных на проверенном акте либо воспроизводящих его положения, хотя о них и не упоминалось во вносимом на рассмотрение Конституционного суда вопросе.

Решение Конституционного суда принимается открытым голосованием. Судья Конституционного суда не вправе воздерживаться или не участвовать в голосовании. Решение Конституционного суда считается принятым, если за него проголосовало большинство от присутствующих на заседании судей. В случае, когда голоса разделились поровну, голос председательствующего является определяющим. 
Судья Конституционного суда, не согласный с решением Конституционного суда, вправе изложить свое мнение в письменном виде и приобщить его к протоколу заседания Конституционного суда.

В соответствии со ст. 32 данного закона указывается, что решение Конституционного суда по существу рассмотренного дела о конституционности международного договора и нормативно-правового акта именуется постановлением. Постановления выносятся Конституционным судом именем Республики Узбекистан. В других случаях решение Конституционного суда именуется заключением или может иметь иную форму.

Порядок опубликования решений Конституционного суда и вступление их в силу нашли свое отражение в ст. 33 Конституционного закона «О Конституционном суде Республики Узбекистан». Постановления, заключения и иные решения Конституционного суда публикуются в средствах массовой информации и на официальном веб-сайте Конституционного суда. Официальными источниками опубликования решений Конституционного суда являются «Собрание законодательства Республики Узбекистан», газеты «Халк сузи» и «Народное слово», «Вестник Конституционного суда Республики Узбекистан», а также Национальная база данных законодательства Республики Узбекистан. Решение Конституционного суда вступает в силу со дня его официального опубликования. Решение Конституционного суда окончательно и обжалованию не подлежит.

Решения Конституционного суда имеют преюдициальный характер. В ст.34 Закона предусмотрено, что решение Конституционного суда может быть пересмотрено им по собственной инициативе:

- ввиду вновь открывшихся обстоятельств, неизвестных Конституционному суду в момент вынесения решения;

- в случае изменения конституционной нормы, на основании которой было принято решение;

- в случае признания Конституционным судом принятия данного решения с нарушением установленного порядка производства.

Решение Конституционного суда вступает в силу со дня его опубликования. Решение Конституционного суда является окончательным и обжалованию не подлежит (ст.33 Конституционного закона). Решения Конституционного суда обязательны для всех государственных органов, общественных объединений, предприятий, учреждений, организаций, должностных лиц и граждан. 


\section{Заключение}

За прошедший период в Республике Узбекистан созданы правовые механизмы для системного конституционного контроля законов и иных нормативных правовых актов в целях защиты прав и свобод человека и гражданина. Имеющаяся конституционно-правовая база дает возможность дальнейшего развития конституционного контроля, продолжения активного поиска оптимального сочетания различных форм конституционного контроля, совершенствования конституционного судопроизводства, повышения эффективности конституционного правосудия.

Конституционный суд стремится внести свой вклад в развитие демократического социального правового государства, формирование конституционной доктрины, углубляя и развивая представления о содержании конституционных ценностей и целей, принципов и норм. Ибо деятельность Конституционного суда направлена на претворение в жизнь верховенства Конституции, утверждение конституционной законности, становление конституционализма.

Анализ деятельности Конституционного суда Республики Узбекистан свидетельствует о том, что действующее законодательство, регулирующее конституционное правосудие, нуждается в дальнейшей демократизации и либерализации. Совершенствование деятельности Конституционного суда по проверке конституционности принимаемых в стране законов и подзаконных актов невозможно без разработки четкого правового механизма и процедур конституционного судопроизводства, существенного расширения его полномочий. Поэтому считаем необходимым:

- разработать и принять закон Республики Узбекистан «О Конституционном судопроизводстве», устанавливающий четкие сроки и процедуру совершения процессуальных действий Конституционного суда;

- разработать детальный правовой механизм подачи и рассмотрения индивидуальных и коллективных обращений в Конституционный суд;

- наделить Конституционный суд дополнительными полномочиями по рассмотрению дел о соответствии Конституции страны деятельности политических партий и общественных движений, решению вопросов о признании их неконституционными.

Кроме того, необходимо наделить Конституционный суд дополнительными полномочиями по подтверждению итогов выборов Президента Республики Узбекистан, выборов в нижнюю палату Олий Мажлиса и референдума. Рассмотрение споров, связанных с конституционностью выборов, отнесено к компетенции Верховного суда, хотя в статье 110 Конституции она 
строго определена в сфере гражданского, уголовного и административного судопроизводства.

В современных условиях эффективное конституционное правосудие становится одним из важнейших критериев «зрелости» гражданского общества. Оно предполагает совершенствование соответствующих форм и методов организации судопроизводства.

Таким образом, Конституционный суд является высшим конституционным органом специализированного конституционного контроля, самостоятельно и независимо осуществляющим судебную власть в форме конституционного судопроизводства в целях ограничения публичной власти и обеспечения баланса между ветвями власти, способствующем эффективности конституционного правосудия и судебной защиты прав и законных интересов человека. Достижение этих целей составляет содержание деятельности Конституционного суда, т.е. осуществление конституционного правосудия.

\section{Резюме}

В статье на основе анализа национального законодательства и опыта функционирования конституционного правосудия рассматривается его эволюция как института фундаментальной демократической ценности в реальной общественно-политической жизни Узбекистана. В ней раскрываются элементы доступа к конституционносудебной защите, его пределов и условий реализации, в том числе в толковании нормативного содержания конституционных прав как предмета конституционной судебной защиты прав и свобод человека. В статье обсуждаются проблемы, которые имеют место на практике в процессе реализации Конституционным судом Республики Узбекистан указанных функций и рекомендации по их совершенствованию.

\section{Omon Zakirovich Mukhamedzhanov}

\section{Strengthening the Role of Constitutional Justice in the Protection of Human Rights and Freedoms: Main Trends, Problems and Prospects}

The current article considers the evolution of an institution of constitutional justice as a fundamental democratic value based on the analysis of national legislation and its experience in the real social and political life of Uzbekistan. It reveals the elements of access to constitutional and judicial protection, its limits and conditions for its implementation, including the interpretation of the normative content of constitutional rights as a subject 
of constitutional judicial protection of human rights and freedoms. The article discusses the problems that occur in practice in the process of implementation of these functions by the Constitutional Court of the Republic of Uzbekistan and recommendations for their improvement.

KEY WORDS: Constitutional Court, power of the constitutional court, constitutional justice, constitutional legal proceedings, the status of a judge

\section{Библиография}

A. Abdugaparov, Sodeystvie konstitucionnih sudov i parlamentov v obespechenii verhovenstva Konstitucii, [in:] Konstitucionnoe pravosudie v novom tisyacheletii, Erevan 2009.

F. H. Adilkarieva, O'zbekiston Respublikasi konstituciyaviy sudining huquqiy maomi, Tashkent 2012.

C. B. Bobotov, Konstitucionnaya yusticiya (sravnitel'niy analiz), Moscow 1994.

V. E. Chirkin, Kontrol'naya vlast, «Gosudarstvo i pravo» 1993, № 4.

B. Eshonov, Stanovlenie i razvitie Konstitucionnogo suda Respubliki Uzbekistan, «Vestnik Konstitucionnogo suda RUz» 2001, Vipusk 5.

L. Garlicki, Konstitucionnie sudi protiv verhovnih sudov, «Sravnitelnoe konstitucionnoe pravo» 2007, № 2 (59).

A. R. Glazunov, Konstitucionniy Sud Rossiyskoy Federacii: praktika i perspektivi. Diss. na soisk. uch. step.kand. yurid. nauk., Moscow 1998.

S. Hakimova, Deyatel'nost Komiteta Konstitucionnogo nadzora Uzbekistana v 1990-1991gg., «Vestnik Konstitucionnogo suda RUz.»1999, Vipusk 4.

S. Hakimova, Stanovlenie i sovershenstvovanie konstitucionnogo pravosudiya $v$ Respublike Uzbekistan RUz., «Vestnik Konstitucionnogo suda RUz.» 2005, Vipusk 12.

K. N. Holikov, Stanovlenie i razvitie instituta konstitucionnogo nadzora v Tadjikistane. Diss. na soisk. uch. step, kand.yurid.nauk. Dushanbe. 1996.

B. Ismailov, Osnovnie modeli konstitucionnogo pravosudiya v pravoprimenitel'noy praktike zarubejnih gosudarstv, «Vestnik Konstitucionnogo suda RUz.» 2008, Vipusk 16.

N. Karieva, Konstitucionniy sud v usloviyah sudebno-pravovoy reformi, «Vestnik Konstitucionnogo suda RUz.» 2005, Vipusk.

S. P. Kazankov, Pravovaya priroda resheniy organov konstitucionnogo kontrolya i nadzora: teoreticheskiy aspekt. Avtoref. na diss. na soisk. uch. step. kand. yurid. nauk., Kazan 2006.

M. I. Kleandrov, Sudebnie sistemi gosudarstv-uchastnikov SNG: zakonodatel'noe obespechenie, Moscow 2002.

A. A. Klishas, Konstitucionniy kontrol i konstitucionnoe pravosudie zarubejnih stran, [in:] V. V. Eremyan (ed.), Sravnitelbno-pravovoe issledovanie, Moscow 2007.

A. N. Medushevskiy, Kel'zenskaya model konstitucionnogo pravosudiya i izmenenie konstituciy $v$ stranah vostochnoy Evropi, Moscow 1999.

B. Mirboboev, Dal'neyshaya demokratizaciya vzaimootnosheniy konstitucionnogo suda Respubliki Uzbekistan s drugimi sudami i nacional'nimi institutami po pravam cheloveka, «Vestnik Konstitucionnogo suda RUz.» 2015, Vipusk 19. 
B. Mirboboev, Konstitucionnoe sudoproizvodstvo: problemi i reformi, «Vestnik Konstitucionnogo suda RUz.» 2004, Vipusk 9.

P. M. Mirzalimov, Konstitucionniy Sud Kirgizskoy Respubliki (konstitucionnie osnovi organizacii i deyatelbnosti). Dissertaciya. kandidata yuridicheskih nauk., Moscow 2000.

B. Mustafaev, Aktual'nie voprosi vzaimootnosheniy Verhovnogo suda s Konstitucionnim $i$ Visshim hozyaystvennim sudami Respubliki Uzbekistan, «Vestnik Konstitucionnogo suda RUz.» 2015, Vipusk 19.

B. Mustafaev, Po puti sozdaniya pravovogo gosudarstva, «Vestnik Konstitucionnogo suda RUz.» 2004, Vipusk 10.

A. A. Nurjanova, Osushestvlenie konstitucionnogo kontrolya Konstitucionnim sovetom Respubliki Kazahstan. Avtoref. diss. na soisk. uch. step. kand. yurid. nauk., Chelyabinsk 2006.

A. Shayo, Konstitucionalizm i konstitucionniy kontrol v postkommunisticheskoy Evrope, [in:] Konstitucionnoe pravosudie v postkommunisticheskih stranah: Sb. dokladov, Moscow 1999.

G. Shtaynberger, Modeli konstitucionnoy yurisdikcii, Strasburg 1994.

J. J. Viatr, Konstitucionnaya otvetstvennost v Pol'she, «Konstitucionnoe pravo: Vostochnoevropeyskoe obozrenie» 1996, № 2 (15).

N. V. Vitruk, Konstitucionnoe pravosudie. Sudebnoe konstitucionnoe pravo i process, Moscow 1998. 
Оксана Владимировна Кукуруз

ORCID: 0000-0003-1863-3028

\section{Трансформация общества:}

теоретико-методологические подходы украинских ученых

\section{КЛЮЧЕВЫЕ СЛОВА:}

трансформация общества, политическая трансформаџия, посткоммунистическая трансформаџия, бинарная трансформаџия, патримониализм

В начале независимости Украины, по мнению автора, можно было надеяться, что происходят целенаправленные изменения (модернизация), которые будут способствовать становлению демократического, правового государства с высоким уровнем политической и правовой культуры в обществе, устойчивым экономическим развитием. Однако после нескольких лет изменений, которые не привели страну к обозначенным целям, оказалось, что на практике не срабатывают теории, описанные в научной литературе. Среди причин этого следует, прежде всего, обратить внимание на то, что популярность приобрели теоретические положения, разработанные на основании опыта других стран, без учета украинской посткоммунистической реальности. Со временем украинские ученые начали верифицировать известные теории, создавать собственные концепции, более близкие к украинским условиям и обладающие способностью привести к правильным выводам и изменить существующую практику. Для понимания процессов, происходящих в Украине, по убеждению автора, более подходящей на сегодняшний день является теория трансформации, нежели теория модернизации. Соответственно есть основания считать актуальным исследование интерпретации этой теории украинскими учеными.

В научной литературе существует значительное количество трудов, посвященных социально-политическим изменениям, произошедшим в Украине в условиях ее независимости. Их обзор осуществлен в фундаменталь- 
ном труде Института политических и этнонациональных исследований им. И. Ф. Кураса НАН Украины «Политическая наука в Украине. 1991-2016» (Т. 2, 2016) ${ }^{1}$. Авторы соответствующего раздела существующие исследования отнесли к двум направлениям: общественного перехода и общественнополитического транзита. Учитывая этот и другие труды, целью предлагаемой статьи есть выяснение состояния исследования социально-политических изменений в украинском обществе в контексте теории трансформации. Задачи заключаются в изучении теоретических наставлений касательно исследований явления трансформации; выделении методологических подходов к изучению этого явления; выяснении сущности понятия «трансформация общества» в трудах украинских ученых.

Основательный анализ общественно-политической реальности первого десятилетия независимой Украины сквозь призму теории модернизации осуществил В. Горбатенко в труде «Стратегия модернизации общества: Украина и мир на изломе тысячелетий» (1999). Значительное внимание ученый уделяет политической модернизации, которую понимает как: 1) комплекс научнометодологических средств, ориентированных на объяснение источников, характера и направлений политических изменений; 2) практическое воплощение рационализации власти и политической бюрократии, рост способности политической системы адаптироваться к новым целям, создание эффективной институционально-ролевой системы, ослабление и замена традиционных элит модернизаторскими, преодоление отчуждения населения от политической жизни, постоянное совершенствование нормативной и ценностной систем общества ${ }^{2}$. То есть, модернизация рассматривается как целенаправленные социально-политические изменения в обществе. Политическая модернизация, по мнению ученого, имеет комплексный характер, поскольку не ограничивается политической сферой, а охватывает собой экономическую, социальную, правовую, культурно-духовную и другие сферы общественной жизни.

Исходя из того, что все сферы в обществе и, соответственно, изменения в них, тесно связаны между собой, В. Горбатенко рекомендует социально-политические процессы рассматривать с помощью синтетическиплюралистического подхода. Этот подход предусматривает применение достижений разных наук, в частности, политологии, истории, экономической теории, правоведения, философии, социологии. В исследовании модерниза-

1 О. Рафальський (голова редкол.), М. Кармазіна (член редколегії), О. Майборода (відп. ред. і упоряд), Політична наука в Украӥні. 1991-2016: у 2 m. T. 2: Теоретикометодологічні засади і концептуальні підсумки вітчизняних досліджень, Київ 2016, c. $37-98$.

2 В. П. Горбатенко, Стратегія модернізації суспільства: Україна і світ на зламі тисячоліть, Київ 1999, с. 25. 
ционных и трансформационных процессов в обществе ученый обосновывает необходимость применения таких концептуальных подходов, как системный, синергетический, исторический, сравнительный.

Наряду с этим В. Горбатенко обращает внимание на категории, которые дублируют, тесно соотносятся или дополняют понятие «политическая модернизация». Среди них и «системная трансформация». По его мнению, такие масштабные процессы, как глобализация, демократизация, модернизация и гуманизация, охватываются понятием «трансформация». В публикации «Общественные трансформации новейшего времени как политологическая проблема: геополитические и национальные параметры» (2009) трансформацию В. Горбатенко характеризует как «исторически обусловленный процесс преодоления общественных, политических и структурных противоречий и проблем определенной системы путем ее выхода за рамки собственной социальной организации, предусматривающей кардинальное изменение направлений ее развития, способа мышления на уровне всего общества, характера деятельности его субъектов» ${ }^{3}$.

Поиск парадигмы познания процессов трансформации обществ осуществляет Н. Михальченко в работе «Украинское общество: трансформация, модернизация или лимитроф Европы?» (2001). По его мнению, в таком исследовании важно выяснить, какие реформы являются главными, определяющими - экономические, политические или духовные. Ученый напоминает известные утверждения, имеющиеся в научной литературе, которые обосновывают важность каждого из указанных видов реформ: 1) приоритетность экономических реформ (политические и духовные реформы пребывают в прямой зависимости от экономических); 2) приоритетность политических реформ (преобразования в обществе начинаются с изменений в институтах власти); 3) приоритетность духовных реформ (любые реформы в обществе сначала происходят в умах людей). Н. Михальченко считает, что познавательная парадигма - «вызревание идеи необходимости перемен в определенном направлении - политические реформы - экономические и культурные преобразования, где не может быть постоянного приоритета одного над другим» - является наиболее соответствующей реальным условиям ${ }^{4}$.

Н. Михальченко обращает внимание на значение общественных наук для проведения реформ в обществе, анализирует сложившееся состояние дел в сфере научных исследований. Среди прочего, через 10 лет после обретения

3 В. П. Горбатенко, Суспільні трансформаиії новітнього часу як політологічна проблема: геополітичні та національні параметри, [в:] В. Ф. Солдатенко (кер.) та ін., Суспільнополітичні трансформачії в Україні: від задумів до реалій, Київ 2009, с. 10-11.

4 Н. И. Михальченко, Украинское общество: трансформация, модернизация или лимитроф Европьз? Киев 2001, с. 7. 
Украиной независимости, ученый отмечает недостаточный уровень финансирования теоретических разработок, наличие значительного количества публикаций с критикой власти и небольшое количество комплексных наработок, пригодных для проведения сбалансированных реформ. По убеждению Н. Михальченко, для успешности реформ в Украине необходимо проводить критический анализ действительности, реалистичный анализ человеческого потенциала, сознательное конструирование будущего в различных моделях и вариантах. Комплексность исследований, по его мнению, должна обеспечиваться взаимодействием философской, социологической, политической, экономической, исторической и других наук. Также ученый указывает на необходимость взаимодействия власти и общественных наук, поскольку они, по его мнению, должны обслуживать реальные потребности трансформации Украины.

Трансформацию Н. Михальченко рассматривает как понятие нейтральное по отношению к динамике общественного процесса, его прогрессивных тенденций, то есть она может быть ориентирована на «изменение реалий куда угодно: вперед, назад, в сторону, по кругу и т. д.»5. Ученый считает, что обществоведение в начале независимости Украины не создало научной парадигмы, которая бы позволила сформировать теорию трансформации обществ. Он доказывает, что известные тезисы западных теорий не срабатывают на постсоветском пространстве, в частности потому, что различными есть: исторические условия, техника, технологии, международные экономические и политические отношения, человеческий потенциал. По мнению Н. Михальченко, в такой ситуации «общественная трансформация начинает восприниматься как открытый процесс, который развивается под действием исходных базисных и привходящих ситуационных обстоятельств, целей и средств их достижения в деятельности людей. Это саморегулирующийся, самокорректирующийся процесс и он преимущественно свободен от концептуальной заданности результатов, которые присутствуют в проектах модернизации и реформах» ${ }^{6}$.

А. Романюк в публикации «Общественно-политические трансформации в новообразованных посткоммунистических странах: попытка системного анализа» (2003) обосновывает новый тип общественно-политической трансформации - бинарный. По его мнению, «в пределах одного процесса происходят два типа трансформации: посттоталитарная (социально-политическая) и государственно-созидательная (национально-политическая) ${ }^{7}$. В другой

5 Там же, с. 39.

6 Там же, с. 41.

7 О. Романюк, Суспільно-політичні трансформації в новоутворених посткомуністичних країнах: спроба системного аналізу, «Людина і політика» 2003, nr 5, с. 4. 
публикации «Посткоммунистические трансформации: системный анализ структурных особенностей» (2009) А. Романюк более подробно описывает особенности этих типов трансформаций. Социально-политическая трансформация означает то, что «изменение политической системы требует изменений во всей системе социальных отношений, но не касается государственности» ${ }^{8}$. Такую трансформацию, по мнению ученого, проходили шесть стран из посткоммунистического пространства. Это страны с устоявшейся государственностью - Албания, Болгария, Монголия, Польша, Румыния, Венгрия. Национально-политическая трансформация означает «переход от не суверенного состояния существования страны к национальной суверенной государственности» 9 . Одновременно социально-политическую и национально-политическую трансформации, по мнению А. Романюка, проходили 24 посткоммунистические страны, в том числе и Украина. Ученый считает, что трансформацию лучше всего исследовать с помощью системного подхода. Этот подход помогает увидеть различия между посттоталитарной и поставторитарной трансформациями. Особенности этих видов трансформаций ученый показывает, прежде всего, через три сферы - экономическую, политическую и культурную.

А. Долженков в работе «Украина - Беларусь: опыт политической трансформации» (2003) трансформацию называет одной из форм социальных изменений, а политическую трансформацию - средством общественной трансформации. Последняя, по его мнению, является одновременно и «симптомом кардинальных экономических и культурных изменений», и «эффективным инструментом трансформации других сфер жизни общества» 10 . Также ученый уделяет внимание социальной трансформации. В частности, в выводах отмечается, что «социальная трансформация в современных условиях может быть определена как обусловленное внешними факторами и внутренней необходимостью постепенное, не связанное с изменением правящей элиты, но в то же время радикальное и относительно быстрое изменение социальной природы общества» ${ }^{11}$.

С. Катаев в работе «Современное украинское общество: учебное пособие» (2006) трансформацию определяет как «процесс приобретения обществом новых черт, которые отвечают требованиям времени», как «действие

8 О .I. Романюк, Посткомуністичні трансформації: системний аналіз структурних особливостей, «Вісник Харківського національного університету імені В. Н Каразіна. Серія «Питання політології» 2009, nr 839, с. 44.

9 Там же, с. 45.

10 О. О. Долженков, Україна - Білорусь: досвід політичної трансформаиії, Одеса 2003 , c. 20.

11 Там же, с. 228. 
или процесс изменения формы, вида, природы или характера общества или отдельной структуры» ${ }^{12}$. Понятие «трансформация общества», по мнению С. Катаева, «дает возможность перевести теорию развития на высший уровень обобщения»13. Ученый отмечает нейтральность термина «трансформация» относительно вектора изменений. По его мнению, именно теория трансформации является наиболее подходящей для анализа изменений, происходящих в Украине. Среди сфер общественной жизни, которые в первую очередь трансформируются, ученый называет экономическую, политическую и культурологическую. С. Катаев показывает важность правильного избрания концепции для объяснения изменений. Концепцию он рассматривает как «совокупность взглядов на причины, сущность и способы решения социальных проблем» ${ }^{14}$.

Важные научные разъяснения предоставляет С. Катаев относительно разницы между обществом стабильным и трансформирующимся. В первом обществе результат изменений можно предвидеть, поскольку они происходят в определенных рамках, в соответствии с определенными стандартами. Во втором - изменения предусмотреть практически невозможно, потому что нет устойчивых взаимосвязей между его элементами. Первое общество может быть очень динамичным, а второе - нет, потому что изменения могут и не приводить к переменам. С. Катаев одним из признаков кризиса украинского общества назвал «отсутствие изменений на фоне хаотического бесплодного динамизма» ${ }^{15}$. В то же время ученый считает, что в украинском обществе «решаются задачи сразу нескольких исторических периодов ... не решив всех проблем модернизации, страна, однако, в определенных аспектах перешла к решению задач постмодернизации» ${ }^{16}$. С. Катаев отмечает, что теория трансформации, как наиболее адекватная для описания изменений, которые происходят в украинском обществе, нуждается в более полной разработке.

А. Фисун в работе «Демократия, неопатримониализм и глобальные трансформации» (2006) анализирует основные подходы к исследованию демократических трансформаций и указывает на существенные отличия этого процесса в Латинской Америке, Южной Европе и посткоммунистических странах. Он считает, что постсоветское развитие было направлено не на установление демократии, а на неопатримониализм. Ученый отмечает, что понятие «патримониализм» происходит от слова «раtrimonium», которое в римском праве означало наследственное, родовое имущество. Впоследствии

12 С. Л. Катаєв, Сучасне украӥнське суспільство: навч. посібник, Київ 2006, с. 13, 14.

13 Там же, с. 194.

14 Там же, с. 19.

15 Там же, с. 20.

16 Там же, с. 191. 
его начали активно использовать немецкие историки и юристы. А. Фисун показывает вклад различных ученых в эту концепцию, в частности, таких как М. Вебер, Г. Рот, Ш. Эйзенштадт. Особенностью патримониализма есть «апроприация (присвоение) сферы управления официальными носителями политической власти, а также нерасчлененность публично-политической и частной, приватной сферы социума, в результате чего государство управляется как частное владение («вотчина») правящих групп, которые на основе системы власти-собственности приватизируют различные общественные функции и государственные институты» ${ }^{17}$.

Важным принципом функционирования неопатримониальной системы А. Фисун называет клиентарно-патронажные отношения. Такой подход к пониманию состояния, в котором пребывает украинское общество, отличный от подходов большинства украинских ученых, предопределяет и совершенно иное понимание процесса трансформации. На основе указанного концептуального подхода, А. Фисун выделяет два возможных варианта осуществления трансформации: «политическая рационализация» снизу (через «цветные революции») и «силовая рационализация» сверху (через «бюрократическую революцию») ${ }^{18}$.

О. Бабкина в публикации «Демократические детерминанты трансформации украинского общества» (2007) обращает внимание на то, что эффективность посткоммунистической трансформации возможна, если она будет происходить синхронно в политической, экономической, социальной и духовной сферах. В то же время на практике, после 15 лет построения независимой Украины она отмечает два вектора трансформационных процессов: 1) связан с изменениями политических институтов, общественного сознания в направлении демократизации; 2) связан с движением в обратном направлении: сохранение и развитие институтов авторитарного режима, процесс олигархизации. Ученый видит в этом особую разновидность общественной трансформации - «формирование новейшего варианта авторитаризма, четко просматриваемого на фоне слабо выраженных демократических институтов»19.

М. Шаповаленко в работе «Политическое развитие современных переходных обществ: теоретические подходы и основные тенденции» (2007) рассматривает трансформацию как одну из характеристик развития. Она указывает на отличия между понятиями «модернизация» и «трансформация».

17 А. А. Фисун, Демократия, неопатримониализм и глобальные трансформации, Харьков 2006, с. 154.

18 Там же, с. 205.

19 О. Бабкіна, Демократичні детермінанти трансформації украӥнського суспільства, «Персонал» 2007, nr 2, http://personal.in.ua/article.php?ida=442 (дата обращения: 15.11.2018). 
В частности, модернизация рассматривается как направленность изменений; как движение системы к определенным параметрам; как целенаправленные действия для получения определенных стандартов уровня развития экономики, а также построения формальных институтов демократии. Зато трансформация - как масштабность изменений; как достаточно интенсивное, направленное и одновременное протекание модернизационных процессов, хотя в различных сферах общества - с разной скоростью; как взаимодействие целенаправленных действий и социальных проектов, иррациональной и рациональной активности различных акторов, в которой задействованы различные уровни и факторы ${ }^{20}$. Политическое развитие, по ее мнению, «это процесс качественных изменений в политических институтах и структурах политической системы (политическая система здесь понимается в самом широком смысле этого слова), способствующих выработке адекватных моделей реакций на различные внешние воздействия» 21 .

Ю. Шайгородский в публикации «Понятие «трансформация» как инструмент анализа социальных изменений» (2010) уделяет внимание эвристическому потенциалу понятия «трансформация» 22 . Он считает, что «трансформация» вместе с такими понятиями как «модернизация» и «глобализация» образует определенную категориальную матрицу для описания сущности и особенностей современных цивилизационных преобразований ${ }^{23}$. Среди систем, которые представляют важность для общественной трансформации постсоциалистической страны, Ю. Шайгородский называет политическую, правовую, экономическую.

Т. Загороднюк в работе «Концепции постсоветской трансформации общества Т. И. Заславской и Н. В. Паниной» (2013) анализирует теории современных социальных изменений и поддерживает мнение, что для изменений, происходящих в Украине, более подходящей является теория трансформации, чем социальной эволюции, модернизации или демократического транзита. Последние, по ее убеждению, предусматривают «обязательное наличие вектора социальных изменений и основанные на идеологии поступательного развития и прогресса», а теория трансформации «основной акцент делает на неоднозначности, разнонаправленности, социокультурной обусловленности и неопределенности результатов декларированных преобразований в совре-

20 М. В. Шаповаленко, Политическое развитие современных переходных обществ: теоретические подходы и основные тенденции, Харьков 2007, с. 22.

21 Там же, с. 334.

22 Ю. Шайгородський, Поняття «трансформація» як інструмент аналізу соиіальних змін, „Освіта регіону” 2010, nr 4, http://social-science.com.ua/article/323 (дата обращения: 25.11.2018).

23 Ю. Шайгородський, Політика: взаємодія реальності і міфу: автореф. дис ... д-ра політ. наук, Київ 2009, с. 11. 
менных обществах, переживающих кардинальные изменения в различных сферах социальной жизнедеятельности» ${ }^{24}$.

Т. Загороднюк детально анализирует наработки Н. Паниной относительно трансформации украинского общества. Среди ее достижений она отмечает такие: разработка целостной теории и методологии социологического исследования трансформационных процессов, которые до сих пор используются Институтом социологии НАН Украины при осуществлении социологического мониторинга изменений в украинском обществе; сочетание в исследованиях системного, структурно-функционального и социокультурного, социально-психологического научных подходов; создание нормативно-личностной концепции трансформации украинского общества. Согласно последней, «институциональные изменения в переходном обществе обусловлены совокупностью ценностных ориентаций субъектов социальной интеграции и их идивидуально-личностных ресурсов, которые определяют способ адаптации к изменяющимся условиям, что, в свою очередь, влечет за собой изменение стиля поведения и содержания поведения» ${ }^{25}$. Концепция постсоветской трансформации украинского общества Н. Паниной, по мнению Т. Загороднюк «позволяет дать оценку, сравнение и прогноз развития трансформационных процессов как в отдельно изучаемом обществе, так и в различных обществах» ${ }^{26}$.

Итак, проанализировав некоторые труды О. Бабкиной, В. Горбатенко, А. Долженкова, Т. Загороднюк, С. Катаева, Н. Михальченко, А. Романюка, А. Фисуна, Ю. Шайгородского, М. Шаповаленко видим, что понятие «трансформация» упоминается в исследованиях, посвященных проблемам политического развития, перехода, транзита, модернизации, демократизации, глобализации. Также трансформацию украинского общества рассматривают в контексте концепции бинарной трансформации (А. Романюк), теории патримониализма (А. Фисун), нормативно-личностной концепции (Н. Панина).

В проанализированных выше трудах речь идет о трансформации общества (общественной трансформации), включающей такие важные сферы общественной жизни, как политическая, экономическая, культурная/культурологическая/духовная, социальная, правовая. Ученые признают взаимосвязь этих сфер, поэтому среди методологических подходов, которые они рекомендуют использовать, упоминаются: синтетически-плюралистический, исторический, системный, структурно-функциональный, сравнительный, синергетический, социокультурный, социально-психологический.

24 Т. Загороднюк, Конщепции постсоветской трансформаџии общества Т. И. Заславской и Н. В. Паниной, Киев 2013, с. 136.

25 Там же, с. 138.

26 Там же, с. 134. 
Исходя из позиций украинских ученых, автор считает, что понятие «трансформация общества» имеет два измерения - теоретическое и прикладное. В соответствии с первым, это концепция объяснения изменений в обществе, которая направлена на поиск причин и факторов - внутренних и внешних, целенаправленных и стихийных, объективных и субъективных и т. д., влияющих на направление развития определенного общества. В соответствии со вторым, это процесс изменений в обществе, которые, в первую очередь, касаются политических институтов, правовых норм, экономических отношений, человеческих ценностей.

\section{Резюмe}

В статье проанализированы труды украинских ученых, в которых уделяется внимание понятию «трансформация общества» («общественная трансформация»). Раскрыта сущность теорий и концепций, в рамках которых ученые предлагают рассматривать трансформацию украинского общества, в частности, бинарная трансформация, патримониализм, нормативно-личностная концепция. Определяется два измерения понятия «трансформация общества» - теоретическое и прикладное.

\section{Oksana Vladimirovna Kukuruz}

\section{Transformation of Society: Theoretical and Methodological Approaches of UKrainian Scientists}

The works of Ukrainian scientists, in which attention is paid to the notion of "transformation of society" ("social transformation"), are analyzed in the article. The essence of theories and concepts, in which scientists propose to consider the transformation of Ukrainian society, in particular, binary transformation, patrimonialism, normatively-personality conception is revealed. The author defines two dimensions of the notion "transformation of society" - theoretical and applied.

KEY WORDS: transformation of society, political transformation, post-communist transformation, binary transformation, patrimonialism 


\section{Библиография}

O. Babkina, Democratic Determinants of the Transformation of Ukrainian Society, «Personnel» 2007, No. 2, http://personal.in.ua/article.php?ida=442 (accessed: 15.11.2018).

O. Dolzhenkov, Ukraine - Belarus: Experience of Political Transformation, Odesa 2003.

A. A. Fisun, Democracy, Neopatrimonialism and Global Transformations, Kharkov 2006.

V. P. Gorbatenko, Public Transformations of the Modern Time as a Political Problem: Geopolitical and National Parameters, [in:] V. F. Soldatenko (ed.), Social and Political Transformations in Ukraine: from Intentions to Realities, Kyiv 2009.

V. P. Gorbatenko, Strategy of Modernization of Society: Ukraine and the World at the Turn of Millennia, Kyiv 1999.

S. L. Kataev, Contemporary Ukrainian Society, Kyiv 2006.

O. Rafalsky (ed.), Political Science in Ukraine. 1991-2016: 2 t. T. 2: Theoretical and Methodological Principles and Conceptual Results of Domestic Research, Kyiv 2016.

O. I. Romanyuk, Postcommunist Transformations: System Analysis of Structural Peculiarities, «Bulletin of the Kharkiv National University named after V. N. Karazin. Series «Questions of Political Science» 2009, No. 839.

O. I. Romanyuk, Socio-Political Transformations in Newly Formed Post-Communist Countries: the Attempt of Systematic Analysis, «Man and Politics» 2003, No. 5 (29).

Yu. Shaygorodsky, Concept of "Transformation" as an Instrument for the Analysis of Social Changes, «Education of the Region» 2010, No 4, http://social-science.com.ua/article/323 (accessed: 25.11.2018).

Yu. Shaygorodsky, Politics: interaction of reality and myth: author. dis. doc. polit. sciences, Kyiv 2009.

M. V. Shapovalenko, Political Development of Modern Transition Societies: Theoretical Approaches and Main Trends, Kharkov 2007.

T. Zagorodniuk, Concepts of the Post-Soviet Transformation of Society T. I: Zaslavsky and N. V. Panina, Kiev 2013. 


\section{Система органов власти в Республике Беларусь: правовые основы, состояние и перспективы развития}

КЛЮЧЕВЫЕ СЛОВА:

Президент Республики Беларусь, Наџиональное собрание Республики Беларусь, Совет министров Республики Беларусь, Верховный суд Республики Беларусь, Конституционный суд Республики Беларусь, избирательная система, политические партии, преобразование политической системы Республики Беларусь

\section{Конституционные основы действующей системы органов власти}

В настоящее время в Республике Беларусь действует новая редакция Конституции. Она стала результатом изменений и дополнений, принятых на республиканском референдуме 24 ноября 1996 г. По мнению большинства членов первого состава Конституционного суда, Президентом А.Лукашенко была предложена принципиально новая модель государственного устройства страны, которая устанавливала власть одного лица. Поэтому не случайно Конституционный суд в своем решении от 4 ноября 1996 г. признал, что голосование по принятию новой редакции Конституции может иметь лишь рекомендательный характер. Однако с этим решением А. Лукашенко не согласился и придал итогам голосования обязательный характер.

После введения в действие новой редакции Конституции с 27 ноября 1996 г. в Беларуси была сформирована новая система органов власти, в том числе двухпалатный парламент, правительство, новый состав Конституционного суда. Президент как глава государства получил ряд дополнительных полномочий.

Позднее в развитие положений новой редакции Конституции новоявленным парламентом были приняты законы, определяющие статус органов 
власти. В частности, Закон «О Президенте Республики Беларусь» в редакции от 7 июля 1997 г., Закон «О Конституционном суде Республики Беларусь» в редакции от 7 июля 1997 г., Закон «О Совете министров Республики Беларусь» в редакции от 7 июля 1998 г., Закон «О Центральной комиссии Республики Беларусь по выборам и проведению республиканских референдумов» от 30 апреля 1998 г.

Многие вопросы государственной важности стали регулироваться декретами главы государства. Например, 11 декабря 1996 г. были изданы первые три декрета: «Об установлении государственного праздника - Дня независимости Республики Беларусь» (раньше этот праздник отмечался 27 июля в День провозглашения государственного суверенитета Белорусской ССР. - Aвm.), «О внесении изменений и дополнений в Закон Республики Беларусь «О выборах депутатов местных Советов депутатов Республики Беларусь», «Об утверждении Положения о выборах членов Совета Республики Национального собрания Республики Беларусь».

В последующие годы А. Лукашенко продолжил практику издания декретов, изменяющих и дополняющих законы Республики Беларусь.

\section{Президент - глава государства}

В соответствии с новой редакцией Конституции Президент Республики Беларусь является «главой государства, гарантом Конституции Республики Беларусь, прав и свобод человека и гражданина» (ст. 79).

Формально президент принимает меры по охране суверенитета Республики Беларусь, ее национальной безопасности и территориальной целостности, обеспечивает политическую и экономическую стабильность, преемственность и взаимодействие органов государственной власти, осуществляет посредничество между органами государственной власти.

Согласно ст. 84 новой редакции Конституции, президент наделен многочисленными полномочиями, которые перечислены в 30 пунктах и не носят исчерпывающий характер. Ряд полномочий перешли президенту от прежнего парламента, который был досрочно распущен. Например, назначать республиканские референдумы, назначать выборы в Палату представителей и местные представительные органы, назначать членов Центральной избирательной комиссии, назначать на должность премьер-министра (с согласия нижней палаты парламента), назначать председателя и судей Конституционного суда, председателя и судей Верховного суда, председателя и судей высшего хозяйственного суда, председателя и членов правления Национального банка, Генерального прокурора, а также освобождать их от должности. 
Наряду с указами и распоряжениями, президент получил право издавать декреты, имеющие силу законов. При этом многие президентские декреты принимаются вопреки действующим законам. Тем самым, подрываются устои принципа верховенства закона, а также принцип разделения властей.

Начиная с марта 2004 г., А. Лукашенко стал издавать директивы как особые правовые акты. Они, в частности, касались вопросов укрепления общественной безопасности и дисциплины (директива № 1 от 11.03.2004 г.), дебюрократизации государственного аппарата (директива № 2 от 27 декабря 2006 г.), экономии и бережливости (директива № 3 от 14 июня 2007 г.), развития предпринимательской инициативы и стимулирования деловой активности (директива № 4 от 31 декабря 2010 г.), развития двусторонних отношений с Китайской Народной Республикой (директива № 5 от 31 августа 2015 г.).

Позднее директивы получили закрепление в Законе «О нормативных правовых актах Республики Беларусь» (действует в редакции Закона от 17 июля 2018 г. ${ }^{1}$ Согласно ст. 2 Закона, директива Президента Республики Беларусь - это «указ программного характера, издаваемый главой государства в целях системного решения вопросов, имеющих приоритетное политическое, социальное и экономическое значение». Между тем, Конституция (ст. 85) не наделяет президента правом на издание директив, что не позволяет считать их легальным источником права.

Срок полномочий президента - пять лет. В соответствии с прежней редакцией Конституции одно и то же лицо не могло занимать должность президента более двух сроков. Это обстоятельство послужило поводом для инициирования А. Лукашенко референдума от 17 октября 2004 г. На него был вынесен один, но весьма объемный вопрос: «Разрешаете ли Вы первому президенту Республики Беларусь Лукашенко А. Г. участвовать в выборах президента и принимаете ли часть 1 статьи 81 Конституции Республики Беларусь в следующей редакиии: «Президент избирается на пять лет непосредственно народом Республики Беларусь на основе всеобщего, свободного, равного и прямого избирательного права при тайном голосовании»?

С позиции конституционного права возникают сомнения о законности проведения референдума по такому вопросу, поскольку нарушается принцип равенства граждан перед законом. Однако ни один из уполномоченных субъектов не обратился по этому поводу в Конституционный суд.

По данным Центральной избирательной комиссии, 89,3\% избирателей приняли участие в референдуме, из них 74,3\% высказались за предоставле-

1 О нормативных правовых актах Республики Беларусь: Закон Республики Беларусь от 10 января 2000 г., Национальный правовой интернет-портал Республики Беларусь, 31.07.2018 г. 2/2568. 
ние А. Лукашенко права участвовать в очередных выборах и за изменение статьи 81 Конституции в предложенной редакции.

С того времени А. Лукашенко участвует во всех «очередных» выборах и побеждает своих оппонентов.

\section{Парламент - Национальное собрание}

В соответствии с новой редакцией Конституции парламентом страны признается Национальное собрание Республики Беларусь (ст. 90). Он состоит из двух палат: Палаты представителей и Совета Республики.

В Палате представителей - 110 депутатов, избираемых по одномандатным избирательным округам. Совет Республики - это палата территориального представительства. От каждой области и от г. Минска избираются по 8 членов на заседаниях депутатов местных Советов. В отступление от принципа выборности 8 членов в Совет Республики назначает президент Республики Беларусь (ст. 91).

Срок полномочий палат парламента - 4 года. Палаты парламента могут быть распущены в следующих случаях: при отказе в доверии Правительству, выражении вотума недоверия Правительству либо двукратном отказе в даче согласия Президенту на назначение Премьер-министра (ст. 94).

Депутаты Палаты представителей и члены Совета Республики работают в сессионном порядке. Одна сессия начинается со 2 октября и длится до конца года, вторая - со 2-го апреля и длится до летних отпусков.

Следует отметить, что компетенция Палаты представителей носит весьма ограниченный характер. Так, в ст. 97 Конституции приводится исчерпывающий перечень законов, которые могут приниматься этой палатой. Все остальные законы, в том числе связанные с расходами, могут рассматриваться только с одобрения Президента Республики Беларусь.

Палата представителей имеет право назначать выборы президента, давать согласие на назначение премьер-министра, заслушивать доклад премьерминистра о программе деятельности правительства и одобрять или отклонять эту программу.

Депутаты Палаты представителей могут по инициативе не менее одной трети от полного состава выражать вотум недоверия правительству, принимать отставку президента, а также большинством голосов от полного состава Палаты представителей выдвигать обвинение против Президента в совершении государственной измены или иного тяжкого преступления «... а основании соответствующего решения Совета Республики».

Право законодательной инициативы в Беларуси принадлежит президенту, депутатам Палаты представителей, Совету Республики, Правительству, 
а также гражданам, обладающим избирательным правом, в количестве не менее 50 тысяч человек (ст. 99 Конституции).

На практике основным субъектом законодательной инициативы является Президент Республики Беларусь, при котором образован Национальный центр законодательства и правовых исследований. Небольшую часть законопроектов готовят министерства и ведомства под эгидой Правительства.

Последние по времени выборы в белорусский парламент были проведены в сентябре 2016 г. По данным Центральной избирательной комиссии, в них приняли участие 74,6\% избирателей. Партийное представительство в парламенте незначительное: от Коммунистической партии Беларуси 8 депутатов, от Республиканской партии труда и справедливости - 3, от Белорусской патриотической партии - 3, от Либерально-демократической партии -1 , от Объединенной гражданской партии -1 .

В повестку дня сессии Палаты представителей Национального собрания, начавшейся 2 октября 2018 г, включены 11 законопроектов. Среди них: проект закона «Об изменении в Закон Республики Беларусь «О санитарноэпидемиологическом благополучии населения», проект закона «О внесении дополнений и изменений в Закон Республики Беларусь «Об обращении с отходами», проект закона «Об электронном документе и электронной цифровой подписи». Кроме того, депутаты планируют во втором чтении рассмотреть поправки в Уголовный, Уголовно-процессуальный, Уголовноисполнительный кодекс, Кодекс об административных правонарушениях, Процессуально-исполнительный кодекс об административных правонарушениях.

Следует признать, что нынешний парламент Беларуси не обладает качествами, необходимыми для современного парламента, в том числе самостоятельностью, достаточными полномочиями, профессионализмом депутатов. В нем слабо представлены политические партии, а также не реализуются инициативные законопроекты.

\section{Правительство - Совет министров}

Согласно ст. 106 новой редакции Конституции, Правительство - Совет Министров Республики Беларусь - является центральным органом государственного управления. Оно формируется и слагает свои полномочия перед вновь избранным Президентом Республики Беларусь.

Правительство состоит из премьер-министра, его заместителей, министров и руководителей иных республиканских органов государственного управления (ч. 4 ст. 106 Конституции). Все они назначаются на должность 
Президентом. Что касается премьер-министра, то он назначается Президентом «с согласия Палаты представителей». Решение по этому вопросу принимается Палатой представителей не позднее чем в двухнедельный срок со дня внесения предложения по кандидатуре премьер-министра. В случае двукратного отказа в даче согласия на назначение премьер-министра Президент вправе назначить исполняющего обязанности премьер-министра, распустить Палату представителей и назначить новые выборы (ч. 5 ст. 106).

Основные полномочия Правительства Республики Беларусь определены в ст. 107 Конституции. Так, Правительство: 1) разрабатывает основные направления внутренней и внешней политики и принимает меры по их реализации; 2) разрабатывает и представляет Президенту для внесения в Парламент проект республиканского бюджета и отчет о его исполнении; 3) обеспечивает проведение единой экономической, финансовой, кредитной и денежной политики, государственной политики в области науки, культуры, образования, здравоохранения, экологии, социального обеспечения и оплаты труда; 4) принимает меры по охране прав и свобод граждан, защите интересов государства, национальной безопасности и обороноспособности, охране собственности и общественного порядка, борьбе с преступностью; 5) выступает от имени собственника в отношении имущества, являющегося собственностью Республики Беларусь, организует управление государственной собственностью; 6) обеспечивает исполнение Конституции, законов, декретов, указов и распоряжений Президента; 7) осуществляет иные полномочия, возложенные на него Конституцией, законами и актами Президента.

Более детально вопросы организации и деятельности Правительства регламентируются в Законе «О Совете Министров Республики Беларусь» от 23 июля 2008 г. (действует в редакции Закона от 17 июля 2018 г.) $)^{2}$.

В настоящее время Премьер-министром Республики Беларусь является Сергей Румас, бывший руководитель Банка развития Республики Беларусь. Он был назначен президентским указом от 18 августа 2018 г. Тем же указом А. Лукашенко заменил ряд заместителей премьер-министра и других членов Правительства. Позднее, 5 октября 2018 г., С. Румас был утвержден в должности Палатой представителей.

В качестве основных задач экономической политики нового состава Правительства С. Румас назвал: «... формирование благоприятной бизнес-среды для развития малого и среднего предпринимательства; опережающее развитие сферы услуг, строительства, транспорта и логистики; постепенный переход к цифровизации всех отраслей экономики и формирование IT-страны;

2 О Совете Министров Республики Беларусь: Закон Республики Беларусь от 23 июля 2008 г., Национальный правовой интернет-портал Республики Беларусь, 28.07.2018 г., $2 / 2570$. 
повышение качества управления государственными активами и эффективности функционирования этого сектора экономики...»³.

Одним из приоритетных направлений деятельности Правительства, по словам С. Румаса, должно стать повышение уровня и качества жизни населения. До конца 2018 г. планируется увеличить среднюю заработную плату по стране до 1000 рублей (500 долларов США). В настоящее время средние заработки в Беларуси в полтора раза ниже, чем в России и почти в три раза меньше, чем в Польше.

Что касается статуса Правительства Республики Беларусь, то оно находится в подчинении Президента Республики Беларусь и действует по его указаниям (это касается, в частности, решения вопросов о повышении заработных плат и пенсий). За время правления А. Лукашенко (с 20 июля 1994 г.) сменилось 7 составов Правительства.

\section{Судебная система}

Вопросы организации и деятельности судов регулируются в главе 6 Конституции (ст. 109-116). В ней устанавливается, что система судов строится на принципах территориальности и специализации (ст. 109), что судьи при осуществлении правосудия независимые и подчиняются закону (ст. 110), что суды осуществляют правосудие на основе Конституции и «...принятых в соответствии с ней иных нормативных актов» (ст. 112), что правосудие осуществляется на основе состязательности и равенства сторон в процессе (ст. 115).

В ст. 116 Конституции закрепляются основы статуса Конституционного суда Республики Беларусь. Он формируется в количестве 12 судей из числа высококвалифицированных специалистов в области права, имеющих, как правило, ученую степень. При этом 6 судей назначается Президентом Республики Беларусь, а 6 - избирается Советом Республики - верхней палатой Парламента, сроком на 11 лет. Председатель Конституционного суда назначается Президентом Республики Беларусь с согласия Совета Республики.

Правом обращения в Конституционный суд наделяются Президент, Правительство, палаты Парламента, Верховный суд (ранее такое право имел Высший хозяйственный суд, но позднее он был преобразован и включен в состав Верховного суда. - Авт.).

3 Парламент дал согласие на назначение Сергея Румаса Премьер-министром Республики Беларусь (pravo.by/novosti/novosti-pravo-by/2018/october/30711, (дата обращения: 20.01.2019). 
К компетенции Конституционного суда относится рассмотрение следующих категорий дел, в том числе: о соответствии законов, декретов, указов Президента, международных договорных и иных обязательств Республики Беларусь Конституции и международно-правовым актам, ратифицированным Республикой Беларусь; о соответствии актов межгосударственных образований, в которые входит Республика Беларусь, указов Президента, изданных во исполнение закона, Конституции, международно-правовым актам, ратифицированным Республикой Беларусь, законам и декретам; о соответствии постановлений Совета Министров, актов Верховного суда, Генерального прокурора Конституции, международно-правовым актам, ратифицированным Республикой Беларусь, законам, декретам и указам; о соответствии актов любого государственного органа Конституции, международно-правовым актам, ратифицированным Республикой Беларусь, законам, декретам и указам.

В ст. 116 Конституции отмечается, что Конституционный суд по предложениям Президента «...дает заключение о наличии фактов систематического или грубого нарушения палатами Парламента Конституции Республики Беларусь».

Действующая система судов Республики Беларусь, как и полномочия судов, получили свое закрепление в Кодексе «О судоустройстве и статусе судей в Республике Беларусь» 4 .

По вопросам организации и деятельности судов издавались также президентские акты. Так, 26 июня 2008 г. А. Лукашенко издал декрет № 14 «О некоторых мерах по совершенствованию деятельности Конституционного суда Республики Беларусь 5 .

В частности, Конституционный суд получил пять новых полномочий:

1) осуществлять обязательный предварительный конституционный контроль законов, принятых палатами Парламента, до подписания их Президентом Республики Беларусь;

2) излагать позицию о конституционности международных договоров до подписания их Президентом Республики Беларусь;

3) по поручению Президента давать официальное толкование декретов и указов, касающихся конституционных прав, свобод и обязанностей граждан;

4) по предложению Совета Республики Национального собрания Республики Беларусь принимать решение о наличии фактов систематического или грубого нарушения местным Советом требований законодательства;

4 О судоустройстве и статусе судей в Республике Беларусь: Кодекс Республики Беларусь от 29 июня 2006 года, Национальный реестр правовых актов Республики Беларусь, 2006, № 107, 2/1236; 2012, № 52, 2/1906.

5 О некоторых мерах по совершенствованию деятельности Конституционного суда Республики Беларусь: Декрет Президента Республики Беларусь от 26 июня 2008 г. № 14, Национальный реестр правовых актов Республики Беларусь, 27.06.2008, № 1/9829. 
5) по предложениям Президента, палат Парламента, Правительства излагать свою позицию о документах, принимаемых (издаваемых) иностранными государствами, международными организациями и (или) их органами и затрагивающих интересы Республики Беларусь в части соответствия этих документов общепризнанным принципам и нормам международного права.

Декрет определил также формы и порядок реализации предоставленных полномочий. Например, решение о проведении предварительного конституционного контроля законов должно приниматься в пятидневный срок со дня поступления обращения в суд. В такой же срок должно приниматься решение о проверке конституционности международных договоров.

10 октября 2011 г. был издан президентский указ № 454 «О мерах по совершенствованию деятельности судов общей юрисдикции Республики Беларусь» (действует в редакции указа от 29 ноября 2013 г.) 6 .

Данным указом было утверждено Послание о перспективах развития системы судов общей юрисдикции. Среди предлагаемых мер: обеспечение дальнейшего повышения качества, оперативности и доступности правосудия; принятие мер по оптимизации судебной нагрузки и совершенствованию процедуры судопроизводства; исключение фактов необоснованного осуждения и привлечения к административной ответственности; улучшение исполнения судебных постановлений и иных исполнительных документов.

На основании президентских актов с января 2014 г. было начато проведение объединения судов общей юрисдикции и хозяйственных судов в одну систему во главе с Верховным судом. Правовой основой объединения судов послужили три президентских акта, изданные 29 ноября 2013 года: Декрет № 6 «О совершенствовании судебной системы Республики Беларусь»; Указ № 529 «О некоторых вопросах деятельности судов Республики Беларусь»; Указ № 530 «О некоторых вопросах совершенствования организации исполнения судебных постановлений и иных исполнительных документов» 7 .

Логичным последствием объединения судов стало изложение в новой редакции Кодекса о судоустройстве и статусе судей в декабре 2016 г. Из него был исключен раздел, посвященный хозяйственным судам.

6 О мерах по совершенствованию деятельности судов общей юрисдикции Республики Беларусь: Указ Президента Республики Беларусь от 10 октября 2011 г. № 454, Национальный правовой интернет-портал Республики Беларусь, 30.11. 2013 г., 1/14649.

7 О совершенствовании судебной системы Республики Беларусь: Декрет Президента Республики Беларусь № 6; О некоторых вопросах деятельности судов Республики Беларусь: Указ Президента Республики Беларусь № 529; О некоторых вопросах совершенствования организации исполнения судебных постановлений и иных исполнительных документов: Указ Президента Республики Беларусь № 530, Национальный реестр правовых актов Республики Беларусь, 29.11.2013, № 1/14649, 1/14650, 1/14651. 
Вопросам судебной организации посвящены ряд работ белорусских авторов, в частности, И. И. Мартинович ${ }^{8}$, В. Н. Бибило 9 , Г. А. Василевича ${ }^{10}$, автора статьи ${ }^{11}$.

В настоящее время в Беларуси насчитывается около 1200 судей общих судов. Нагрузка на одного судью составляет около 70 материалов в месяц. Ежегодно судами рассматривается около 40 тысяч уголовных дел, 350 тысяч дел об административных правонарушениях, 200 тысяч гражданских дел и 20 тысяч дел экономического характера.

Так, по итогам 2017 г. судами было рассмотрено 39619 уголовных дел, по которым было осуждено свыше 43 тысяч человек. Из них: 12020 к лишению свободы, 7951 - к ограничению свободы, 71777 - к штрафу, около 2000 - к исправительным работам. Число оправданных составило 98 человек, в основном, по делам частного обвинения ${ }^{12}$.

Особенностью судебной политики последних лет является большое количество решений об административных штрафах и арестах. Например, за 2017 г. были подвергнуты штрафам свыше 235 тысяч человек, свыше 50 тысяч - арестам на срок до 15 суток. В Беларуси субъектами административной ответственности являются также субъекты хозяйствования, включая предпринимателей. За 2017 год судами было вынесено более 5300 штрафов за экономические, финансовые и налоговые правонарушения в отношении субъектов хозяйствования.

С июля 2016 г. в уголовном судопроизводстве была введена апелляция вместо кассации. Это расширило возможности судов второй инстанции при проверке законности и обоснованности приговоров, не вступивших в законную силу. Суды апелляционной инстанции получили право выносить по итогам судебного разбирательства новые решения по существу дела. С 2018 г. апелляционная форма проверки судебных постановлений была введена в гражданском процессе.

Оценивая практику судов Беларуси, следует признать, что суды пока не стали гарантами защиты прав и свобод граждан. В ряде случаев они уклоняются от рассмотрения жалоб граждан на действия и решения органов управления и должностных лиц, проявляют тенденциозность при рассмо-

8 А. А. Данилевич (ред.), Судоустройство: учебник, Минск 2010.

9 В. Н. Бибило, Белорусское судоустройство, Минск 2018.

10 Г. А. Василевич, Конституционное правосудие, Минск 2012.

11 М. И. Пастухов, Становление и развитие судебного конституциионного контроля в Республике Беларусь (1994-2014 г2.), «Социально-экономические и правовые исследования» 2015, № 4, с. 129-134; М. И. Пастухов, Судебная система Беларуси: состояние, проблемы, перспективы, «Вопросы правоведения» 2015, № 5, с. 79-82.

12 Статистические данные о деятельности судов общей юрисдикции за 2017 год (court. gov.by/ru/justice_rb/statistics), (дата обращения: 23.11.2018). 
трении некоторых категорий дел об административных правонарушениях, а также уголовных дел. Это предопределяет необходимость усиления гарантий судебной защиты прав и свобод граждан.

\section{Местные органы власти}

Действующая система органов местного управления и самоуправления была сформирована в период правления А. Лукашенко. Тогда были изданы несколько президентских указов, в частности: от 19 сентября 1995 г. № 383 «О проведении реформы местного управления и самоуправления»; от 20 октября 1995 г. № 434 «Об объединении административных единиц Республики Беларусь, имеющих общий административный центр»; от 27 ноября 1995 г. № 481 «Об утверждении примерной структуры местных администраций в районах городов»; от 30 ноября 1995 г. № 485 «О внесении изменений и дополнений во Временное положение о местной администрации».

В соответствии с этими указами были упразднены районные Советы депутатов в г. Минске и областных центрах, а большинство районов были объединены в одну административно-территориальную единицу с районными городами. Следствием объединения районов и городов явилось упразднение Советов депутатов и исполкомов в городах и городских поселках, что серьезно ослабило позиции местной власти.

Позднее Конституционный суд признал некоторые из вышеназванных указов несоответствующими Конституции и законам Республики Беларусь. Однако, вопреки конституционным гарантиям, они продолжали действовать в полном объеме.

В настоящее время система органов местного управления и самоуправления Республики Беларусь закрепляется в разделе 5 новой редакции Конституции (ст. 117-124) и в Законе «О местном управлении и самоуправлении в Республике Беларусь» от 4 января 2010 г. (действует в редакции Закона от 9 января 2018 г.).

Согласно ст. 117 Конституции, местное управление и самоуправление осуществляется гражданами через местные Советы депутатов, исполнительные и распорядительные органы, органы территориального самоуправления, местные референдумы, собрания и другие формы прямого участия в государственных и общественных делах.

В систему местного самоуправления включаются местные Советы депутатов, избираемые непосредственно населением, органы территориального общественного самоуправления, местные собрания, местные референдумы 
и «...иные формы участия граждан в государственных и общественных делах».

В Беларуси действует три звена местных Советов депутатов: областные, районные (городские) и сельские (поселковые) Советы. Минский городской совет обладает также правами Совета базового уровня.

Система местного управления представлена исполнительными комитетами, а также районными администрациями в г. Минске, областных центрах и двух районах г. Бобруйска.

В соответствии с поправками, внесенными в Закон о местном управлении и самоуправлении, а также вышеназванными президентскими указами система местных органов управления была выведена из подчинения местных представительных органов. Руководители исполкомов стали назначаться на должность и освобождаться от должности Президентом Республики Беларусь. В результате таких преобразований в стране сформировалась так называемая «президентская вертикаль».

В Республике Беларусь имеется 6 областных Советов и исполкомов, 118 районных Советов и исполкомов, 24 районных администрации в Минске и областных центрах, 1160 сельских Советов и исполкомов, 19 поселковых Советов и исполкомов. Город Минск имеет особый статус столицы Беларуси.

В пределах своей компетенции местные Советы депутатов, исполнительные и распорядительные органы принимают решения, имеющие обязательную силу на соответствующей территории. При этом решения местных Советов депутатов, не соответствующие законодательству, могут быть отменены вышестоящими Советами, а решения местных исполнительных и распорядительных органов - соответствующими Советами депутатов, вышестоящими исполнительными комитетами, а также Президентом Республики Беларусь (ст. 59 Закона).

В настоящее время высказываются предложения по совершенствованию административно-территориального устройства и системы местного управления и самоуправления Республики Беларусь. Так, провластные эксперты предлагают укрупнить ряд районов с целью оптимизации численности государственного аппарата. Независимые эксперты настаивают на двухуровневой системе местного самоуправления. При этом они полагают, что местное самоуправление в Беларуси следует организовать на принципах Европейской хартии местного самоуправления с учетом опыта европейских стран, в том числе Республики Польша ${ }^{13}$.

13 М. В. Кобаса и др., Местное самоуправление в Беларуси: материаль исследований ПОО «Фонд имени Льва Сапеги в рамках программь Европейского Союза и Совета Европь, Минск 2017, с. 60-62. 


\section{Избирательная система}

В Республике Беларусь продолжает действовать мажоритарная избирательная система советского типа. Она «дрейфует» в сторону демократизации, однако сохраняет основные положения этой системы, а именно: принуждение граждан к участию в выборах; формирование избирательной комиссии из числа провластных представителей; жесткие требования к регистрации кандидатов в депутаты; тайный подсчет голосов избирателей.

Основы избирательной системы закрепляются в разделе 3 Конституции «Избирательная система. Референдум» (ст. 64-78). Дополнительное развитие они получили в Избирательном кодексе Республики Беларусь, принятом 11 февраля 2000 г. (с изм. и доп.).

По мнению специалистов в области избирательного законодательства, «Кодекс сохранил все недостатки переформатированной в Беларуси советской избирательной системы. По многим своим позициям он не соответствует международно-правовым нормам и (...) не обеспечивает проведение свободных и справедливых выборов» ${ }^{14}$.

В Избирательном кодексе получили отражение практически все вопросы, касающиеся выборов. В нем также регулируются вопросы организации и проведения республиканских референдумов (раздел 7), отзыва депутатов Палаты представителей, членов Совета Республики (разделы 8 и 9).

В качестве основных принципов избирательной системы Республики Беларусь закрепляются: всеобщее избирательное право; свободные выборы; равное избирательное право; прямое избирательное право (в отношении выборов членов Совета Республики - косвенное избирательное право); тайное волеизъявление.

Согласно ст. 64 Конституции, ст. 4 Избирательного кодекса, в выборах (референдумах) не участвуют граждане, признанные судом недееспособными; лица, содержащиеся по приговору суда в местах лишения свободы. Кроме того, в голосовании не принимают участия лица, в отношении которых избрана мера пресечения в виде содержания под стражей.

Следует признать, что последняя категория граждан включена в «запретный список» в нарушение права каждого не признаваться виновным в совершении преступления до тех пор, пока его вина не будет доказана в установленном законом порядке (ст. 26 Конституции). Однако указанное ограничение остается в избирательном законодательстве, лишая заключенных под стражу права принимать участие в выборах.

14 С. А. Альфер (ред.), Выгоры: правовые основы, избирательные технологии, Минск 2000, c. 9. 
Несмотря на то, что выборы провозглашаются свободными, на практике граждан принуждают к досрочному голосованию (по данным общественных наблюдателей, не меньше $30 \%$ избирателей в Беларуси голосует досрочно. - Aвm.).

Избирательные комиссии в Беларуси формируются органами исполнительной власти из числа угодных для них представителей. Центральная избирательная комиссия в составе 12 человек формируется на паритетных началах Президентом и Советом Республики. Председателем этой комиссии с 14 ноября 1996 г. бессменно является Лидия Ермошина. На эту должность она была назначена в ходе проведения ноябрьского референдума 1996 г. вместо освобожденного президентским указом Виктора Гончара.

В составе избирательных комиссий практически отсутствуют представители оппозиционных политических партий, что лишает результаты голосования достоверности.

Избирательный кодекс допускает три способа выдвижения кандидатов в депутаты: от политических партий, от трудовых коллективов и путем сбора подписей избирателей. Преобладает первый способ. Однако, как показывает практика, более надежным является второй способ - от трудовых коллективов. Им предпочитают пользоваться представители от власти или, как их называют, «правильные кандидаты». Вариант со сбором подписей избирателей является весьма обременительным, поскольку граждане опасаются ставить свои подписи за оппозиционных кандидатов.

Что касается выдвижения кандидатов в президенты, то устанавливается единый способ выдвижения - путем сбора не менее 100000 подписей. При этом должна быть сформирована инициативная группа в количестве не менее 100 человек. Она подлежит регистрации в Центральной избирательной комиссии с выдачей группе подписных листов, которые должны заполняться в точно установленном порядке. Правильность заполнения подписных листов и достоверность подписей проверяется избирательными комиссиями.

В случае, если суммарное количество недостоверных подписей избирателей, выявленных при проверках, составит более $15 \%$ от общего количества проверенных подписей, то дальнейшая проверка подписей прекращается и все подписи избирателей в поданных подписных листах не учитываются (ст. 61 Избирательного кодекса).

В результате собрать 100000 подписей может далеко не каждый претендент на должность президента, что показала практика президентских выборов 2015 года.

Серьезные нарекания оппозиционных политических партий вызывают так называемое досрочное голосование. Согласно ст. 53 Избирательного 
кодекса, оно проводится не ранее чем за пять дней до выборов (референдума). При этом не требуется подтверждения причин невозможности избирателя прийти на досрочное голосование.

Практика проведения выборов в Беларуси выявила ряд типичных нарушений общепризнанных стандартов в области избирательного законодательства. В их числе: 1) недемократический и непрозрачный порядок формирования избирательных комиссий; 2) предоставление всяких преимуществ кандидатам от власти; 3) принуждение избирателей к досрочному голосованию; 4) сокрытие от общественности числа избирателей на участках и процента досрочно проголосовавших; 5) закрытый от наблюдателей подсчет голосов избирателей; 6) наличие фальсификаций при подведении итогов выборов на всех уровнях; 7) ограничение возможностей обжалования нарушений законности при проведении выборов; 8) уничтожение избирательных бюллетеней через 6 месяцев после выборов.

\section{Основные политические партии}

В соответствии со ст. 5 Конституции граждане могут создавать политические партии в целях выражения своей политической воли и участия в выборах. В то же время запрещается создание и деятельность партий, а равно других общественных объединений, имеющих целью насильственное изменение конституционного строя либо ведущих пропаганду войны, социальной, национальной и религиозной вражды.

В Республике Беларусь действует Закон «О политических партиях» от 5 октября 1994 г. (с изм. и доп.). Согласно ст.10 Закона, для создания и деятельности политической партии требуется не менее 1000 учредителей (членов) от большинства областей Республики Беларусь и г. Минска. При этом партия должна иметь организационные структуры, создаваемые в порядке, «...установленном законодательством и уставом политической партии».

Следует отметить, что на начало 1999 г. в Беларуси было зарегистрировано 43 политические партии. Однако после издания президентского декрета от 26 января 1999 г. № 2 «О некоторых мерах по упорядочению деятельности политических партий, профессиональных союзов, иных общественных объединений» была проведена перерегистрация партий и иных общественных объединений. В результате в Беларуси осталось 15 политических партий. Попытки инициативных групп зарегистрировать новые партии успехом не увенчались.

Из политических партий примерно половина поддерживает политику нынешней власти, в том числе: Коммунистическая партия Беларуси, 
Республиканская партия труда и справедливости, Республиканская партия, Белорусская аграрная партия, Белорусская социально-спортивная партия, Белорусская патриотическая партия, Либерально-демократическая партия, Социально-демократическая партия народного согласия.

Другая часть партий находится в оппозиции к действующей власти. Среди них: Белорусская партия левых «Справедливый мир», Белорусская партия «Зеленые», Объединенная гражданская партия, Партия БНФ, Консервативнохристианская партия БНФ, Белорусская социал-демократическая партия, Партия «Белорусская социал-демократическая Громада».

В настоящее время политические партии Беларуси представляют убогое зрелище. Они малочисленные. Приток новых сил в партии незначительный. Финансирование партий носит непрозрачный характер. Рейтинги партий среди населения весьма низкие.

Представители политических партий высказывают ряд предложений по развитию партийного движения в стране. В частности, речь идет о введении смешанной избирательной системы, при которой партии получат гарантированное представительство в парламенте и местных представительных органах; о финансовой поддержке партий со стороны государства; об упрощении процедуры регистрации политических партий; о прекращении преследования политических активистов.

\section{Программа преобразований в государственно-правовой сфере}

Все больше белорусских юристов приходят к убеждению, что политическая система Республики Беларусь нуждается в кардинальных преобразованиях.

Первым шагом в этом направлении может быть восстановление Конституции 1994 г., которая была незаконно приостановлена по результатам референдума 1996 г. Принятие такого решения повлечет за собой проведение досрочных выборов президента, парламента и местных представительных органов. Предполагается, что выборы будут проводиться новыми составами избирательных комиссий.

Следующим шагом может стать воссоздание системы легитимных органов власти с предварительной корректировкой их полномочий. В этой связи нуждается в уточнении статус президента, который не должен доминировать над остальными органами власти. Парламент должен быть однопалатным с широким партийным представительством. К его компетенции следует отнести формирование коалиционного правительства и других органов власти, 
включая судей высших судов, членов Центральной избирательной комиссии, членов Национального банка, Генерального прокурора.

Деятельность политических партий должна получить максимальное развитие. Парламент и местные органы власти должны формироваться преимущественно из числа новой политической элиты.

В новом регулировании нуждается организация судебной власти. В этой связи предлагается следующая программа мер: 1) перейти к избранию судей по конкурсу; 2) основным звеном судебной системы сделать межрайонные (окружные) суды; 3) ввести суд с участием присяжных заседателей по уголовным делам, где обвиняемый не признает себя виновным в совершении преступления; 4) предоставить судам право решать вопрос о достаточности оснований для заключения подозреваемых (обвиняемых) под стражу, а также о проведении следственных действий, связанных с посягательством на права и свободы граждан; 5) возложить на суды обязанность рассматривать жалобы на действия (решения) органов управления и должностных лиц, нарушающие права и свободы граждан; 6) расширить полномочия Конституционного суда, в том числе рассматривать жалобы граждан на нормативные акты, которые нарушают их конституционные права и свободы; 7) наполнить реальным содержанием судейское самоуправление.

В соответствующих преобразованиях нуждается организация местной власти. Свою окончательную форму она может получить после реформы административно-территориального устройства страны. Очевидно, что местные представительные органы должны иметь право формировать свои органы управления.

В новых условиях следует усилить гарантии обеспечения и защиты прав и свобод граждан. Для этого предлагается: отменить смертную казнь как вид уголовного наказания; учредить должность уполномоченного по правам человека; расширить практику защиты прав граждан со стороны всех юристов, а не только адвокатов.

\section{Резюмe}

В статье анализируется правовой статус и деятельность основных органов власти Республики Беларусь, исследуются особенности избирательной системы, порядок формирования и деятельности политических партий, а также высказываются предложения по совершенствованию политической системы Республики Беларусь. 
Mikhail Ivanovich Pastukhov

\section{The System of Authorities of the Republic of Belarus: Legal Framework, State and Development Prospects}

The article analyzes the legal status and activities of the main authorities of the Republic of Belarus, examines the features of the electoral system, the order of formation and activities of political parties, and also makes suggestions for improving the political system of the Republic of Belarus.

KEY WORDS: President of the Republic of Belarus; National Assembly of the Republic of Belarus; Council of Ministers of the Republic of Belarus; Supreme Court of the Republic of Belarus; Constitutional Court of the Republic of Belarus; electoral system; political parties; transformation of the political system of the Republic of Belarus

\section{Библиография}

S. A. Alfer (ed.), Elections: legal framework, electoral technology, Minsk 2000.

V. N. Bibilo, Belarusian Judiciary, Minsk 2018.

A. A. Danilevich (ed.), Judiciary: textbook, Minsk 2010.

M. V. Kobas (ed.), Local Self-Government in Belarus: Materials for VEO The Lev Sapegi Foundation under the European Union and Council of Europe, Minsk 2017.

M. I. Pastukhov, Formation and Development of Judicial Constitutional Control in the Republic of Belarus (1994-2014), «Socio-Economic and Legal Studies» 2015, No. 4.

M. I. Pastukhov, The Judicial System of Belarus: Status, Problems, Perspectives, «Issues of Jurisprudence» 2015, No. 5.

G. A. Vasilevich, Constitutional Justice, Minsk 2012. 


\section{Трансформация президентской власти в Казахстане: выбор между демократией и социально-политической стабильностью}

КЛЮЧЕВЫЕ СЛОВА: геополитика, президент, ротация власти, разделение властей

\section{Введение}

Казахстан, будучи девятым в мире по площади государством, граничит с такими странами как Китай (на юго-востоке) и Россия (на востоке, севере, северо-западе), а также на юге - Узбекистаном, Киргизией, Туркменистаном. Ни одна из стран, граничащих с Республикой Казахстан, не является демократической, а, следовательно, эти государства по определению не могли «взять на буксир» Казахстан в сторону демократии. В этом плане, страны Балтии в 90-х годах удачно использовали исторический шанс быть в Европе и успешно интегрировались в Европейский Союз. Республика Беларусь, будучи территориально европейским государством, все же предпочитает оставаться в очень сложной постсоветской политической действительности, являясь членом Евразийского Экономического Союза, куда входит и Казахстан.

Сложившееся геополитическое окружение Республики Казахстан оказывает большое влияние на политическое положение в стране, формирование модели политического управления. Как известно, в последние годы в странах-соседях (Китай, Россия) взят курс на юридическое закрепление режима пребывания глав государств на неограниченный период времени.

Так, 11 марта 2018 года Всекитайское собрание народных представителей одобрило поправку в Конституцию КНР, которая позволяет Си 
Цзиньпину переизбираться на свою должность неограниченное число раз 1 . Президент РФ Путин В.В., формально побывав в кресле председателя правительства один срок, снова был избран на новый президентский срок. Выборы президента России 18 марта 2018 года позволяют находится у власти В. В. Путину еще шесть лет. В соответствии с пунктом 1 статьи 81 Конституции РФ «Президент Российской Федерации избирается сроком на шесть лет гражданами Российской Федерации на основе всеобщего равного и прямого избирательного права при тайном голосовании» ${ }^{2}$.

Режимы других граничащих с Казахстаном стран (Узбекистан, Киргизия, Туркменистан) в специальных исследованиях именуются «феноменом демократического цезаризма», а также указывается на тенденцию «олигархизации правящих режимов независимо от конституционных форм их организации» ${ }^{3}$.

Республики, входившие в состав СССР, пережили тяготы сталинских репрессий, массовые насильственные переселения народов, античеловеческие реформы, деление границ внутри Советского Союза без учета мнения населения. Подобные реформы изначально заложили конфликт между некоторыми странами бывшего СССР. В литературе отмечается, что «значительными отличиями для любого государства являются приграничные территории, в которых особым образом обостряются как проблемы сакральной географии, так и ландшафтно-этнические проблемы. Приграничье более проблемно для государства, чем обширные внутренние пространства» ${ }^{4}$.

Референдум в Республике Крым произвел огромный резонанс в информационном пространстве Республики Казахстан. В некоторых СМИ, интернет-ресурсах эта тема связывается со статусом Северных областей Казахстана. Очевидно, что у любого человека вызывают негативную реакцию провокационные высказывания в адрес его страны, земли, на которой он родился, живет и связывает с ней свое будущее 5 . К сожалению, подобная информационная атака подкрепляется словами известных политиков, депутатов, что, безусловно, объективно заставляет поставить на чашу весов

1 Китайские депутаты разрешили главе государства править бессрочно https://ria.ru/ world/20180311/1516105193.html (дата обращения: 20.01.2019).

2 Конституция Российской Федерации http://www.constitution.ru/ (дата обращения: 20.01.2019).

3 А. Медушевский, Политические режимьв в Средней Азии: конституционные реформы в рамках авторитарной модернизации, «Сравнительное Конституционное Обозрение» 2012, № 4, с. 55-59.

4 А. Н. Кольев, Нациия и государство. Теория консервативной реконструкции, Москва 2005 , с. 117.

5 М. Т. Габдуалиев, Референдум в Крыму: давайте поставим во главу угла права Человека! «Вестник Саратовской государственной юридической академии» 2015, № 5 , c. 58 . 
выбор между политической стабильностью, территориальной целостностью страны - с одной стороны и реальными конституционными реформами с другой.

Насколько законсервированная «стабильность» и «косметические» правовые реформы способны удержать страну от политических потрясений в Казахстане (находящемся в Евразийском геополитическом пространстве) в период политического транзита? Закон от 5 июля 2018 года № 178-VI ЗРК «О Совете Безопасности Республики Казахстан» ${ }^{6}$, принятый казахстанским парламентом, является одним из пазлов в сложной внутриполитической конфигурации в преддверии транзита власти.

\section{Вопросы ротации президентской власти в решении Конституционного Совета Республики Казахстан}

Действующий президент Казахстана находится в своей должности с 1991 года. Политико-правовой статус президента Казахстана в своем развитии прошел несколько этапов, что обусловлено особенностями внутриполитического развития республики, изменением содержательной стороны государственной власти ${ }^{7}$. Следует отметить, что названный вопрос носит политический характер и периодически в стране возникали различные споры по поводу режима власти одного лица на столь длительном отрезке времени.

Н. А. Назарбаева 1 декабря 1991 года избрали президентом Казахстана; 29 апреля 1995 года на республиканском референдуме срок его полномочий был продлен до 1 декабря 2000 года.

30 августа 1995 года на республиканском референдуме была принята новая Конституция РК, закрепившая пятилетний срок президентства. Однако, 7 октября 1998 года парламентом РК был принят Закон РК «О внесении изменений и дополнений в Конституцию Республики Казахстан 1995 года» ${ }^{8}$, в соответствии с которым срок полномочий президента был установлен в семь лет. 8 октября 1998 года срок полномочий президента РК Н. А. Назарбаева, установленный республиканским референдумом 29 апреля 1995 года, был продлен до вступления в должность нового президента Республики Казахстан, избранного на президентских выборах, которые были назначены

6 Закон от 5 июля 2018 года № 178-VI ЗРК «О Совете Безопасности Республики Казахстан», «Казахстанская правда» 2018 г. от 12 июля, № 130.

7 См. подр.: В. А. Малиновский, Глава государства суверенного Казахстана, Астана 1998, с. 14-15; В. А. Малиновский, Лидер: президентская власть в Казахстане на рубеже эпох: Монография, Астана 2012, с. 17-120.

8 «Казахстанская правда» 1998 г. 8 октября. 
парламентом РК на 10 января 1999 года. На этих выборах президентом Республики был избран Н. А. Назарбаев.

Данные политические события привели к тому, что 9 июня 2000 года в Конституционный Совет РК поступило обращение председателя Мажилиса Парламента РК об официальном толковании пункта 5 статьи 42 Конституции РК. При толковании данной конституционной нормы субъект обращения просил установить, распространяется ли предусмотренный ею запрет на избрание президентом республики более двух сроков подряд на лицо, осуществлявшее полномочия президента Казахстана до избрания его на эту должность на выборах, состоявшихся 10 января 1999 года.

При рассмотрении данного обращения Конституционный Совет исходил из следующего. Согласно пункту 5 статьи 42 Конституции РК «одно и то же лицо не может быть избрано президентом Республики более двух раз подряд». Приведенная конституционная норма свидетельствует о том, что одно и то же лицо может быть избрано в порядке статьи 41 Конституции РК 1995 года и соответствующего ей Конституционного закона РК «О выборах в Республике Казахстан» только два раза подряд. Институт президентства в Казахстане был введен Законом Казахской ССР «Об учреждении поста Президента Казахской ССР и внесении изменений и дополнений в Конституцию (Основной Закон) Казахской ССР» от 24 апреля 1990 года, на основании которого первый президент Казахстана был избран 24 апреля 1990 года Верховным Советом Казахской ССР. В соответствии с Законом Казахской ССР «О выборах Президента Казахской ССР» от 16 октября 1991 года и Постановления Верховного Совета Казахской ССР «О назначении выборов президента Казахской ССР» от 16 октября 1991 года выборы президента Казахской ССР были назначены на 1 декабря 1991 года. Верховный Совет Казахской ССР выдвинул кандидатом в президенты Казахской ССР Н. А. Назарбаева, избранного 1 декабря 1991 года гражданами Казахстана президентом. Присяга президентом Казахской ССР народу республики приносилась на Конституции Казахской ССР 1978 года.

Первая Конституция Республики Казахстан как независимого государства, принятая 28 января 1993 года Верховным Советом Республики, в статье 10 «Переходных положений» сохранила полномочия президента Республики, избранного в соответствии с законодательством Казахской ССР. На республиканском референдуме, состоявшемся 29 апреля 1995 года по инициативе Ассамблеи народов Казахстана, согласно Постановлению Центральной комиссии референдума РК № 13 от 3 мая 1995 года срок полномочий первого президента Казахстана был продлен до 1 декабря 2000 года. Постановлением Парламента РК от 8 октября 1998 года N103-1 срок полномочий президента Республики Н. А. Назарбаева, установленный республиканским референ- 
думом 29 апреля 1995 года, сокращен до вступления в должность нового Президента РК, избранного на президентских выборах, назначенных Мажилисом Парламента РК на 10 января 1999 года. Постановлением ЦИК РК от 19 ноября 1999 года Н. А. Назарбаев в числе других претендентов был зарегистрирован кандидатом в Президенты РК. Постановлением ЦИК РК от 15 января 1999 года № 3/182 Президентом РК зарегистрирован Н. А. Назарбаев, избранный 10 января 1999 года на основе действующих Конституции Республики и Конституционного закона «О выборах в Республике Казахстан». Принимая во внимание все вышеизложенные обстоятельства, а также то, что с принятием Конституции РК 1995 года кардинальным образом изменилась конституционная система, установившая новую форму правления Республики и статус президента Казахстана как главы государства и его высшего должностного лица, Конституционный Совет РК считает, что первый срок полномочий президента Республики Казахстан, предусмотренный Конституцией РК 1995 года с изменениями и дополнениями от 7 октября 1998 года, следует исчислять с момента официального вступления в должность Президента Республики Казахстан - с 20 января 1999 года.

Конституционный Совет РК постановил, что на основании Конституции 1995 года и в соответствии с Конституционным законом РК «О выборах в Республике Казахстан» 10 января 1999 года президент РК был избран впервые. Согласно новому объему конституционных прав и обязанностей впервые избранным на альтернативной основе президентом РК была принесена присяга народу Казахстана на Конституции 1995 года. Таким образом, Конституционный Совет РК пришел к выводу, что в соответствии с пунктом 5 статьи 42 Конституции РК 1995 года по истечении в 2006 году срока полномочий действующего Президента РК он может быть избран Президентом РК второй раз подряд.

19 августа 2005 года Конституционный Совет РК вынес Постановление «Об официальном толковании пунктов 1 и 3 статьи 41 и пункта 1 статьи 94 Конституции Республики Казахстан» ${ }^{9}$, в котором говорится, что очередные выборы президента РК должны быть проведены в первое воскресенье декабря 2005 года. Таким образом, на этих выборах Н. А. Назарбаев вправе баллотироваться, поскольку по Конституции РК 1995 года этот срок будет считаться вторым по счету.

Для сравнения, если обратиться к современной конституционно-правовой истории Российской Федерации времен Б. Н. Ельцина, необходимо отметить, что с аналогичным запросом о толковании части 3 статьи 81 и пункта 3 раздела второго «Заключительные и переходные положения» Конституции

9 «Казахстанская правда» 2005, 25 августа, с. 6. 
РФ обращалась Государственная Дума в Конституционный Суд РФ. По данному запросу Конституционный Суд РФ вынес Определение от 5 ноября 1998 года № 134-0 «По делу о толковании статьи 81 (часть 3) и пункта 3 раздела второго «Заключительные и переходные положения» Конституции Российской Федерации», в котором был сделан вывод, что президент РФ до выборов в июне-июле 1996 года осуществлял свои полномочия первый срок и был избран в 1996 году на второй срок подряд. В обоснование данного определения Конституционным Судом РФ были положены следующие аргументы.

Первый аргумент. Свободные выборы, согласно статье 3 (часть 3) Конституции РФ, являются высшим непосредственным выражением власти народа. В этой связи доводы о том, что предусмотренные статьей 81 (часть 3) Конституции РФ ограничения продолжительности полномочий одного и того же президента двумя сроками подряд относится якобы только к случаю, когда оба срока полностью имели место в период действия нынешней Конституции РФ, и что указанный в пункте 3 ее раздела второго «Заключительные и переходные положения» срок не является сроком в смысле статьи 81 (часть 3), вступает в противоречие с выраженной на выборах волей народа.

Второй аргумент носит более политический характер чем юридический. В Определении Конституционного Суда РФ указано на необходимость учитывания того, что сам Президент РФ, являясь согласно статье 80 (часть 2) Конституции РФ гарантом Конституции РФ, неоднократно публично заявлял, что на очередных выборах в 2000 году не будет баллотироваться на должность президента РФ на следующий срок полномочий, ибо это было бы нарушением Конституции РФ, и что он не намерен добиваться ее изменения ради выдвижения своей кандидатуры. Говоря о последнем (скорее политическом) аргументе, необходимо отметить, что президент РК Н. А. Назарбаев, в своих официальных выступлениях, напротив - в отличие от экс-президента России Б.Н. Ельцина, заявлений, о том, что он не будет баллотироваться на очередных президентских выборах, не высказывал. Здесь необходимо также отметить следующее. Анализируя конституционно-правовое развитие наших стран можно сформулировать вывод о том, что на его вектор оказывает влияние не объективные факторы, а субъективные - своего рода «политическая доктрина», которая формулируется и создается на основе политической воли лидера, его политикосубъектности.

Законом РК от 21 мая 2007 года № 254 «О внесении изменений и дополнений в Конституцию Республики Казахстан» ${ }^{10}$ конституционная норма пун-

10 Закон Республики Казахстан от 21 мая 2007 года № 254 «О внесении изменений и дополнений в Конституцию Республики Казахстан», Ведомости Парламента РК 2007 год, № 10, ст. 68 . 
кта 5 статьи 43 Конституции РК была изменена. В соответствии с новой редакцией Конституции ограничение о том, что «одно и то же лицо не может быть избрано Президентом Республики более двух раз подряд», «на Первого Президента Республики Казахстан не распространяется». Занимавший в тот период должность Председателя Конституционного Совета РК - И. Рогов прокомментировал эту конституционную норму, что для ее действия необходимо: во-первых, чтобы завершился конституционный срок полномочий ныне действующего Президента Казахстана; во-вторых, Первый Президент должен изъявить желание баллотироваться на новый президентский срок; в-третьих, чтобы народ избрал Первого Президента на новый срок. Этим же законом срок полномочий президента был сокращен с семи до пяти лет.

В целом, произошедшие за последние двадцать семь лет в Казахстане политические процессы оказали соответствующее влияние на вектор конституционно-правового развития страны и, прежде всего, - на правовую институционализацию сильной президентской власти. Сказанное, еще подтверждает высказанное мнение, что «в известном смысле право - это сгусток политики» ${ }^{11}$.

В Российской Федерации норма Конституции о невозможности одного и того же лица занимать должность Президента более двух раз подряд, нашла свое развитие и обоснование в правовых позициях Конституционного Суда РФ, а политическая воля предыдущего Президента России Б. Н. Ельцина и следующего главы государства В. В. Путина позволили обеспечить сменяемость власти демократическим путем. Хотя в последующем В. В. Путин, побыв один срок председателем правительства РФ, снова баллотировался на новый президентский срок.

Таким образом, нахождение Н. А. Назарбаева на посту Президента Казахстана с 1991 года нашло свое правовое обоснование в постановлениях Конституционного Совета РК, в соответствии с которыми, юридически, по Конституции РК 1995 года нынешний глава государства был вправе баллотироваться на новый президентский срок, а майские 2007 года конституционные изменения закрепили право Первому Президенту баллотироваться на очередной президентский срок.

По этому поводу профессор Кельнского университета А. Нуссбергер выразила мнение, что «наиболее откровенный способ игнорирования демократических правил игры - отмена соответствующих временных ограничений, закрепленных в Конституции» ${ }^{12}$. В других исследованиях указывается,

11 Н. И. Матузов, Актуальные проблемь теории права, Саратов 2004, с. 229.

12 А. Нуссбергер, Ограничения президентской власти в посткоммунистических странах, «Сравнительное конституционное обозрение» 2008, № 5, с. 58. 
что «ограничение нахождения президента у власти определенным сроком и ограничение количества сроков его пребывания в должности являются важным правовым барьером, препятствующим превращению президентской власти в многолетнюю личную диктатуру» ${ }^{13}$.

\section{Конституционный Закон «О Лидере Нации»}

В июне 2010 года был принят Конституционный закон «О внесении дополнений и изменений в некоторые конституционные законы Республики Казахстан по вопросам совершенствования законодательства в сфере обеспечения деятельности Первого Президента Республики Казахстан Лидера нации» ${ }^{14}$, названного в широкой общественности «Законом о Лидере нации».

Этот закон наделил Первого Президента Республики Казахстан определенным объемом полномочий. Так, в соответствии со статьей 1 Конституционного закона РК от 20 июля 2000 года № 83-II «О Первом Президенте Республики Казахстан - Лидере Нации» ${ }^{15}$, Первому Президенту Республики Казахстан - Лидеру Нации в силу его исторической миссии пожизненно принадлежит право:

1) обращаться к народу Казахстана, государственным органам и должностным лицам с инициативами по важнейшим вопросам государственного строительства, внутренней и внешней политики и безопасности страны, которые подлежат обязательному рассмотрению соответствующими государственными органами и должностными лицами;

2) выступать перед Парламентом Республики Казахстан и его Палатами, на заседаниях Правительства Республики при обсуждении важных для страны вопросов; возглавлять Ассамблею народа Казахстана; входить в состав Конституционного Совета, Совета Безопасности Республики Казахстан. Разрабатываемые инициативы по основным направлениям

13 Н. В. Бобракова, Институт главы государства в странах СНГ: сравнительноправовой анализ. Автореф. дисс... канд.юрид. наук, Саратов 2008, с. 17.

14 Конституционный Закон Республики Казахстан от 14 июня 2010 года № 289-IV «О внесении изменений и дополнений в некоторые конституционные законы Республики Казахстан по вопросам совершенствования законодательства в сфере обеспечения деятельности Первого Президента Республики Казахстан - Лидера Нации», ВП РК, № 11, ст. 55.

15 Конституционный закон Республики Казахстан от 2 января 2012 года № 526-IV О внесении дополнения в Конституционный закон Республики Казахстан «О Первом Президенте Республики Казахстан - Лидере Нации», ВП РК 2012 г., № 1, ст. 2. 
внутренней и внешней политики государства согласовываются с Первым Президентом Республики Казахстан - Лидером Нации.

Конституционным закон РК от 15 июня 2017 года № 75-VI ЗРК «О внесении изменений и дополнений в некоторые конституционные законы Республики Казахстан» ${ }^{16}$ были внесены изменения в Конституционный закон Республики Казахстан от 20 июля 2000 года «О Первом Президенте Республики Казахстан - Лидере Нации» ${ }^{17}$. В соответствии с вышеназванными изменениями в заголовке и по всему тексту Конституционного закона слова «Лидер Нации» были заменены словом «Елбасы» 18 , т.е. в прямом казахском звучании слова «Лидер Нации», что не меняет сути и смысла закона.

В последние годы в Казахстане наблюдается проведение внеочередных выборов Президента. 3 апреля 2011 года состоялись внеочередные выборы Президента Республики Казахстан, по итогам которых, согласно постановлению ЦИК РК от 5 апреля 2011 года № 45/76, действующий Президент РК Н. А. Назарбаев набрал 95,55 процентов голосов избирателей, принявших участие в голосовании ${ }^{19} .26$ апреля 2015 года состоялись внеочередные выборы Президента Республики Казахстан. По данным ЦИК РК, явка избирателей составила 95,22\%. Н. А. Назарбаев набрал 8833250 голосов или 97,75 процента голосов избирателей, принявших участие в голосовании ${ }^{20}$.

Э. Б. Мухамеджанов по этому поводу отмечает, что «без отсутствия четко обозначенных в законе оснований, когда глава государства может принять решение о назначении внеочередных президентских выборов, он каждый раз, будет лично брать на себя весь груз исторической ответственности при решении этого вопроса. При этом следует иметь в виду, что Президент как

16 Конституционный закон Республики Казахстан от 15 июня 2017 года № 75-VI 3РК «О внесении изменений и дополнений в некоторые конституционные законы Республики Казахстан», «Казахстанская правда» 2017 г. от 14 июля., № 133.

17 Конституционный закон Республики Казахстан от 20 июля 2000 года «О Первом Президенте Республики Казахстан - Лидере Нации, ВП РК 2000 г., № 10, ст. 232; 2010 г., № 11, ст. 55; 2012 г., № 1, ст. 2; 2013 г., № 14, ст. 72; 2014 г., № 16, ст. 89.

18 Конституционный закон Республики Казахстан от 20 июля 2000 года № 83-II «О Первом Президенте Республики Казахстан - Елбасы», ВП РК 2000 г., № 10, ст. 232.

19 Сообщение об итогах внеочередных выборов Президента Республики Казахстан, состоявшихся 3 апреля 2011 года, http://election.kz/rus/informatsiya-o-vyborakhi-referendumakh-v-rk/informatsiya-o-proshedshikh-izbiratelnykh-kampaniyakh/itogivneocherednykh-vyborov-prezidenta-rk-sostoyavshikhsya-3-aprelya-2011-goda.php (дата обращения: 20.01.2019).

20 Сообщение об итогах внеочередных выборов Президента Республики Казахстан, состоявшихся 26 апреля 2015 года, http://www.election.gov.kz/rus/informatsiya-ovyborakh-i-referendumakh-v-rk/informatsiya-o-proshedshikh-izbiratelnykh-kampaniyakh/ itogi-vneocherednykh-vyborov-prezidenta-respubliki-kazakhstan-sostoyavshikhsya-26aprelya-2015-goda.php (дата обращения: 20.01.2019). 
гарант Конституции не имеет права на ошибку, которая может создать отрицательный прецедент и пагубно отразиться на принципе верховенства норм Конституции» ${ }^{21}$.

\section{Изменения и дополнения в Конституцию Республики Казахстан 2017 года}

Президент Казахстана Н. А. Назарбаев 11 января 2017 года подписал распоряжение об образовании Рабочей группы по вопросам перераспределения полномочий между ветвями государственной власти ${ }^{22}$. По итогам ее работы Парламентом Казахстана были внесены изменения и дополнения в Конституцию ${ }^{23}$.

Пункт 2 статьи 41 Конституции был изложен в новой редакции: «Президентом Республики Казахстан может быть избран гражданин Республики по рождению, не моложе сорока лет, свободно владеющий государственным языком, проживающий в Казахстане последние пятнадцать лет и имеющий высшее образование. Конституционным законом могут устанавливаться дополнительные требования к кандидатам в Президенты Республики».

В отличие от прежней редакции в Конституции был закреплен новый ценз - «наличие высшего образования», а также на уровень парламентского законотворчества было делегировано установление дополнительных требований к кандидатам в Президенты Республики.

Казахстанский парламент не стал медлить и внес изменения ${ }^{24}$ в Конституционный закон Республики Казахстан от 28 сентября 1995 года № 2464 «О выборах в Республике Казахстан» 25 в части установления дополнительных требований к кандидатам в президенты.

21 Э. Б. Мухамеджанов, Субъективный взгляд по вопросу досрочных (внеочередных) выборов главы государства, http://www.zakon.kz/4691665-subektivnyjj-vzgljad-povoprosu.html (дата обращения: 20.01.2019).

22 Назарбаев распорядился создать Рабочую группу по смене полномочий между ветвями власти, HYPERLINK "http://www.zakon.kz/4838728-nazarbaev-rasporjadilsjasozdat.html” http://www.zakon.kz/4838728-nazarbaev-rasporjadilsja-sozdat.html (дата обращения: 20.01.2019).

23 Закон Республики Казахстан от 10 марта 2017 года № 51-VI ЗРК «О внесении изменений и дополнений в Конституцию Республики Казахстан», «Казахстанская правда» 2017 г. от 14 марта, № 51.

24 Конституционный закон Республики Казахстан от 15 июня 2017 года № 75-VI ЗРК «О внесении изменений и дополнений в некоторые конституционные законы Республики Казахстан, «Казахстанская правда» 2017 г. от 14 июля., № 133.

25 Конституционный закон Республики Казахстан от 28 сентября 1995 года № 2464 «О выборах в Республике Казахстан», ВВС РК 1995 г., № 17-18, ст. 114. 
Во-первых, это наличие опыта работы на государственной службе или на выборных государственных должностях, составляющий не менее 5 лет.

Во-вторых, устанавливается, что право выдвижения кандидатов в Президенты принадлежит республиканским общественным объединениям, зарегистрированным в установленном порядке. Таким образом, исключается существовавшее ранее и распространенное в зарубежном законодательстве право на самовыдвижение.

В-третьих, статья 59 Конституционного закона «О выборах», регламентирующая процедуру регистрации, была дополнена новым пунктом 2-1, по сути устанавливающим дополнительные требования к кандидатам в президенты (отсутствие заболеваний, препятствующих исполнению обязанностей президента):

2-1. Для подтверждения отсутствия у кандидата в Президенты заболеваний, препятствующих исполнению обязанностей Президента Pеспублики, проводится его медицинское освидетельствование, итоги которого оформляются соответствующим медицинским заключением о состоянии здоровья.

Требования к медицинскому заключению и перечень заболеваний, препятствуюших исполнению обязанностей Президента Республики, устанавливаются совместным нормативным правовым актом Центральной избирательной комиссии и уполномоченного органа в области здравоохранения. ${ }^{26}$

\section{Закон Республики Казахстан «О Совете Безопасности»}

Говоря о Законе РК от 5 июля 2018 года № 178-VI ЗРК «О Совете Безопасности Республики Казахстан» ${ }^{27}$, необходимо отметить, что конституционные реформы марта 2017 года стали первым этапом в транзите власти. Анализ поправок 2017 года в Конституцию, а затем - в Конституционные законы страны позволяют сформулировать вывод, что существует намерение создать некого «коллективного приемника». Это парламент (причем обе его палаты) и правительство.

Во время конституционных реформ стояла задача создать такой механизм в системе власти, чтобы ни один властный институт не мог самостоятельно принять какое-либо ключевое решение. Конституционная реформа 2017 года создала правовой каркас и очертила властный коридор для деятельности

26 Конституционный закон Республики Казахстан от 28 сентября 1995 года № 2464 «О выборах в Республике Казахстан», ВВС РК, 1995 г., № 17-18, ст. 114.

27 Закон от 5 июля 2018 года № 178-VI ЗРК «О Совете Безопасности Республики Казахстан», «Казахстанская правда» 2018 г. от 12 июля, № 130. 
будущего президента. Очевидно, что следующий президент уже не будет так легко получать одобрения тех же кадровых решений по назначению ключевых должностных лиц (председатель КНБ, Генеральный прокурор, председатель Национального Банка) со стороны Сената и других важных решений. Нужно будет договариваться.

В тоже время общество, и в первую очередь заинтересованные в этом лица, не застрахованы от того, что в транзитный период что-то пойдет не по плану.

По этой причине появился запрос на закон «О Совете Безопасности». Следует обратить внимание на интересную деталь этого законопроекта.

К функциям Совета Безопасности будут отнесены «обсуждение кандидатур, рекомендуемых к назначению на должности первых руководителей центральных и местных исполнительных органов областей, города республиканского значения и столицы, а также государственных органов, непосредственно подчиненных и подотчетных Президенту Республики Казахстан» (пп. 8) ст. 3).

В пунктах 5 и 6 статьи 6 закона закрепляется, что "решения Совета Безопасности вступают в силу после утверждения Председателем Совета Безопасности, при необходимости они реализуются актами Президента Республики Казахстан. Решения Совета Безопасности и Председателя Совета Безопасности являются обязательными к исполнению государственными органами, организациями и должностными лицами Республики Казахстан».

Законом предусматривается, что «Первому Президенту Республики Казахстан - Елбасы в силу его исторической миссии пожизненно принадлежит право возглавлять Совет Безопасности в качестве Председателя» (п. 2 ст. 1).

Принятие Закона «О Совете безопасности» направлен на создание некого «предохранителя» на транзитный период, на случай, если элиты не смогут цивилизованно договорится. По этой причине Совету Безопасности придали статус конституционного органа. Если предположить, что после вступления в должность следующего президента начнется «форс-мажор» или предпосылки к нему, то у Первого президента Казахстана сохранится возможность контролировать этот процесс.

Если у Совета Безопасности не будет статуса конституционного органа, то будет не ясен юридический статус его решений во властной иерархии, адресуемых государственным органам, должностным лицам, организациям.

В то же время регулирование конституционного органа в обычном законе вызывает вопросы. Насколько правильно статус конституционного органа регламентировать обычным законом? 
Следует также обратить внимание на одну немаловажную деталь принятого пакета законодательных актов 5 июля 2018 года. Как известно, в статье 10 действующего Закона РК «О правовых актах» ${ }^{28}$ устанавливается иерархия нормативных правовых актов. Так вот, Законом РК от 5 июля 2018 года № 179-VI ЗРК «О внесении изменений и дополнений в некоторые законодательные акты Республики Казахстан по вопросам деятельности Совета Безопасности Республики Казахстан» ${ }^{29}$ пункт 5 статьи 10 Закона РК «О правовых актах» был изложен в новой редакции:

5. Акты Председателя Совета Безопасности Республики Казахстан, нормативные постановления Конституционного Совета Республики Казахстан и Верховного Суда Республики Казахстан находятся вне иерархии нормативных правовых актов, установленной настоящей статьей.

Ранее пункт 5 статьи 10 Закона РК «О правовых актах» содержал положение, что вне иерархии нормативных правовых актов находятся только лишь нормативные постановления Конституционного Совета и Верховного Суда. Появление в этом списке на первом плане актов Председателя Совета Безопасности подтверждает намерение разработчиков данного закона содержательно наполнить функции и статус Совета Безопасности.

\section{Резюмe}

Вышеприведенный анализ эволюции института президента в Казахстане позволяет сформулировать следующие выводы.

Во-первых, за период независимости Казахстан претерпел трансформацию из советско-парламентской к президентской модели республики с элементами монархии (некого азиатского султаната). Геополитическое положение и окружение Казахстана повлияли на институционализацию сильной президентской власти в обмен на «политическую стабильность» не только внутри страны, но и в ЦентральноАзиатском регионе.

Во-вторых, то обстоятельство, что в Казахстане роль ведущего политического института играет президент, привели к тому, что сегодня в стране принятие ключевых политических решений замыкается на главе государства.

28 Закон Республики Казахстан от 6 апреля 2016 года № 480-V ЗРК «О правовых актах», ВП РК 2016 г., № 7-I, ст. 46.

29 Закон Республики Казахстан от 5 июля 2018 года № 179-VI ЗРК «О внесении изменений и дополнений в некоторые законодательные акты Республики Казахстан по вопросам деятельности Совета Безопасности Республики Казахстан», «Казахстанская правда» 2018 г. от 12 июля, № 130. 
Отсутствие реального разделения властей, политического плюрализма, низкий уровень политико-партийной культуры при переходе власти от действующего бессменного президента Казахстана к новому главе государства содержит в себе политические и конституционные риски.

В-третьих, сформулированные выше обстоятельства стали причиной поиска правовой модели бесконфликтного перехода власти от первого президента Казахстана к следующему.

Принятие Закона «О Совете Безопасности» является попыткой «встроить» в конституционную систему власти еще один государственный орган, который должен дополнить систему сдержек и противовесов, а также стать «подушкой безопасности» в период транзита власти.

\section{Mereke Gabdualiyev}

Transformation of Presidential Power in Kazakhstan: The Choice Between Democracy and Socio-Political Stability

During the period of independence, Kazakhstan has undergone a transformation from the Soviet-parliamentary to the presidential model of the Republic with elements of the monarchy (a certain Asian Sultanate). The geopolitical position and environment of Kazakhstan influenced the institutionalization of strong presidential power in exchange for "political stability" not only within the country but also in the Central Asian region. In Kazakhstan, the role of a leading political institution is played by the President. Today, the country's key political decision-making is confined to the head of state.

The lack of real separation of powers, political pluralism, low level of political and party culture during the transition of power from the current permanent President of Kazakhstan to the new head of state contains political and constitutional risks.

Kazakhstan is looking for a legal model of conflict-free transition of power from the first President of Kazakhstan to the next. The adoption of The law "on the Security Council" is an attempt to "integrate" another state body into the constitutional system of power, which should complement the system of checks and balances, as well as become a "safety cushion" during the transit of power.

KEY WORDS: geopolitics, the President, the rotation of power, separation of powers

\section{Библиография}

N. W. Bobrakova, The Institute of the Head of State in the CIS countries: a comparative legal analysis. Author. Diss ... Ph.D. Sciences, Saratov 2008. 
M. T. Gabdualiyev, Referendum in the Crimea: Let's put man's rights at the forefront! «Bulletin of the Saratov State Law Academy» 2015, № 5.

A. N. Kolev, Nation and State. Theory of Conservative Reconstruction, Moskwa 2005.

V. A. Malinovsky, Head of State of Sovereign Kazakhstan, Astana 1998.

V. A. Malinovsky, Leader: Presidential Power in Kazakhstan at the Turn of Epochs: Monograph, Astana 2012.

N. I. Matuzov, Actual Problems of Theory of Law, Saratov 2004.

A. Medushevsky, Political Regimes in Central Asia: Constitutional Reforms in the Framework of Authoritarian Modernization, «Comparative Constitutional Review» 2012, № 4.

E. B. Mukhamedzhanov, Subjective view on the issue of early (extraordinary) presidential elections, http://www.zakon.kz/4691665-subektivnyjj-vzgljad-po-voprosu.html (accessed: 01.20.2019).

A. Nussberger, Restrictions on Presidential Power in Post-Communist Countries, «Comparative Constitutional Review» 2008, № 5. 
Шахзод Алихонович Сайдуллаев

ORCID: 0000-0001-8670-9851

\section{Вопросы совершенствования}

научно-теоретических и методологических основ нормотворческой деятельности в Республике Узбекистан на фоне зарубежного опыта

\section{КЛЮЧЕВЫЕ СЛОВА:}

нормотворчество, законотворчество, законодательный прочесс, нормативно-правовые акты, прогнозирование

\section{Введение}

В настоящее время в стране осуществляются широкомасштабные реформы направленные на реализацию предусмотренных Стратегией действий по пяти приоритетным направлениям развития Республики Узбекистан в 2017-2021 годы1. В данном документе в числе важнейших задач определены приоритетные направления совершенствования законотворческой деятельности с новыми подходами к законотворчеству и нормотворчеству, так как сложившаяся в стране ситуация с нормотворческим процессом не отвечает требованиям проводимых реформ во всех сферах общественнополитической жизни общества.

Большое количество нормативно-правовых актов, с одной стороны, способствует более эффективному регулированию той или иной группы общественных отношений, но, с другой стороны, без проведения необходимой инвентаризации, систематизации законодательства и без разработки чёткой и ясной научно-методологической основы нормотворческой деятельности невозможно продвижение намеченных реформ. Так как появляется огромное количество правовых дефектов, коллизий, образуется определенная аморф-

1 См.: Указ Президента Республики Узбекистан «О Стратегии действий по дальнейшему развитию Республики Узбекистан» от 7 февраля 2017 г., Собрание законодательства Республики Узбекистан 2017 г., № 6, ст. 70, № 20, ст. 354. 
ность правовой основы государственного регулирования общественных отношений, а иногда и излишняя избыточность такого регулирования.

Указанные проблемы можно решать опираясь на разработанную инновационную научно-теоретичную и методологическую базу, со строго научных, теоретических позиций, в то же время необходим детальный анализ всего массива действующего законодательства.

\section{Состояние и проблемы научно-теоретических и методологических основ разработки и принятия нормативно-правовых актов}

На сегодняшний день в Узбекистане сложилась и действует организационно-правовая, научно-теоретическая и методологическая основы законодательного процесса и нормотворчества.

Нормотворческая деятельность регулируется такими основополагающими законами как «О нормативно-правовых актах», «О порядке подготовки проектов законов и их внесения в Законодательную палату Олий Мажлиса Республики Узбекистан», «О Регламенте Законодательной палаты Олий Мажлиса Республики Узбекистан», «О Регламенте Сената Олий Мажлиса Республики Узбекистан» и другими нормативно-правовыми актами.

Особая роль в проведении единой государственной правовой политики, координации и повышении эффективности правотворческой деятельности, а также методическое руководство и координация деятельности государственных органов и организаций по исполнению законов и других нормативноправовых актов согласно постановлению Президента Республики Узбекистан от 13 апреля 2018 года «Об организационных мерах по дальнейшему совершенствованию деятельности Министерства юстиции Республики Узбекистан» № ПП-3666 отводится Министерству юстиции Республики Узбекистан ${ }^{2}$.

Основой и предпосылкой проведения успешной нормотворческой политики государства является необходимость разработки научно-теоретических и методологических основ, учет современных тенденций и перспектив правового развития общества, и государства, то есть - юридическое прогнозирование. Нормотворческое прогнозирование есть осуществляемое в нормотворческом процессе систематическое, научно обоснованное специальное исследование всех ожидаемых и возможных последствий принятия разрабатываемых проектов нормативно-правовых актов.

2 Национальная база данных законодательства, 14.04.2018 г., № 07/18/3666/1073, 11.07.2018 г., № 06/18/5475/1489. 
В последнее время в нормотворческий процесс при разработке законов и других нормативно-правовых актов все чаще стали внедряться элементы социального партнёрства. В соответствии с ч. 3 ст. 6 Закона Республики Узбекистан «О социальном партнерстве» ${ }^{3}$ одной из основных форм социального партнерства является участие негосударственных некоммерческих организаций и других институтов гражданского общества в разработке и реализации нормативно-правовых актов. Участие различных субъектов при разработке нормативно-правовых актов является общепринятой тенденцией в мировой практике.

На сегодняшний день в Республике функционирует система грантов в различных сферах общественной жизни. Одной из основных задач Министерства инновационного развития Республики Узбекистан является определение приоритетных направлений государственной научно-технической и инновационной политики и утверждение государственных научно-технических программ фундаментальных, прикладных и инновационных исследований на грантовой основе. Также, функционируют различные некоммерческие организации, которые занимаются изучением правовых проблем. В частности, Центр изучения правовых проблем, участвует в разработке законопроектов и других нормативно-правовых актов, проведения независимых экспертиз актов законодательства, аналитических и исследовательских работ в области экономики и права и др.

В процессе изучения состояния научно-теоретической и методологической основы разработки и принятия законов, и других нормативно-правовых актов можно выделить целый ряд следующих проблем нормотворчества: 1) На сегодняшний день возникает проблема определения влияния объективного процесса правообразования на сущностные свойства нормотворчества, носящего субъективный характер. В связи с этим, субъекты нормотворчества при разработке и принятии законов и других нормативно-правовых актов должны ответить на вопрос о возможности учета всех факторов, детерминирующих законодательный процесс с момента выявления необходимости проведения законодательного регулирования той или иной группы общественных отношений, на стадии правотворчества.

2) Требует дальнейшей разработки также вопрос о субъектном составе нормотворчества с формально-юридической и социальной точки зрения. Важность этого вопроса обусловлена сложившейся нормотворческой практикой: расширительное толкование такого субъектного состава

3 См.: Собрание законодательства Республики Узбекистан, 2014 г., № 39, ст. 488; 2017 г., № 37, ст. 978, Национальная база данных законодательства, 05.01.2018 г., № 03/18/456/0512. 
зачастую приводит к возникновению труднопреодолимых препятствий в определении рамок нормотворческой деятельности.

3) Отсутствует единое координирующее звено осуществляющее взаимодействие различных институтов и центров, занимающихся вопросами нормотворческого прогнозирования, что в свою очередь приводит к непродуманным, а порой к поспешным решениям, которые никоим образом не могут способствовать положительному регулированию возникающих проблем в жизни общества. Не разработаны четкие научно-теоретические и методологические основы структур занимающихся нормотворческим прогнозированием и планированием.

4) Одной из основных причин, препятствующих эффективному совершенствованию регуляторной среды, являются проблемы институционального характера, негативно влияющие на качество формирования нормативноправовой и законодательной баз республики. Правовое поле Узбекистана сегодня имеет большое количество законов и подзаконных актов, число которых увеличивается с каждым годом. Из-за интенсивно меняющейся социально-экономической конъюнктуры вновь принимаемые и уже действующие решения порой нарушают определенную последовательность и вступают в противоречие друг с другом, что неблагоприятно сказывается на развитии общественно-политической жизни страны. В данном контексте следует отметить, что основным инструментом, позволяющим оценить эффективность и качество новых принимаемых нормативноправовых актов, является система оценки воздействия актов законодательства (далее - COВАЗ), которая широко используется в мировой практике, но еще не получила должного развития в Узбекистане.

Как отмечают специалисты, занимавшиеся внедрением COBА3, часть составляющих методологических инструментов в той или иной форме в республике уже представлена, однако необходима дальнейшая поддержка этой работы из-за имеющихся здесь проблем институционального характера. Отсутствуют конкретные критерии для определения эффективности результатов, достигнутых на основе применения принятых нормативно-правовых актов, что в свою очередь, усложняет своевременное внесение необходимых изменений и дополнений в соответствующие нормативно-правовые акты.

5) Несмотря на то, что проводятся фундаментальные и прикладные научные исследования и теоретические разработки в области нормотворчества, на сегодняшний день следует признать - юридическая наука несколько отстала от практики. В нормотворческой деятельности недостаточно налажена связь с правовой наукой, слабо применяются предложения и результаты научных исследований. Имеет место дефицит качествен- 
ных аналитических и научно-исследовательских разработок в сфере нормотворчества, правоприменения, мониторинга исполнения законов. Как известно, эти работы требуют высокой концентрации научных ресурсов, финансового обеспечения и наличия самостоятельной организационной структуры. Результаты научных исследований в области нормотворчества вследствии отсутствия единой координационной структуры научных исследований остаются невостребованными, а со временем устаревают. А также не разработаны научно-теоретические и методологические основы проведения научной экспертизы.

6) Инновационные идеи, основанные на изучении передового опыта развитых государств в нормотворческой деятельности, своевременно не внедряются, в то же время до сих пор действуют изжившие себя формы и стереотипы при разработке и принятии законов и других нормативноправовых актов.

7) Следует отметить, что в соответствии со ст. 11 Закона Республики Узбекистан «О порядке подготовки проектов законов и их внесения в законодательную палату Олий Мажлиса Республики Узбекистан» 4 , субъект права законодательной инициативы, в случаях необходимости, в пределах своей компетенции, может поручить в установленном порядке или заказать на договорной основе подготовку проекта закона государственным органам, научным учреждениям и иным организациям, отдельным гражданам. В тоже время для субъектов, участвующих в процессе законотворчества, особенно ученых и специалистов-практиков, не разработаны организационно-правовые и финансовые механизмы стимулирования их деятельности. В частности, в законодательстве не достаточно отражены договорные отношения между субъектами нормотворчества, порядок организации государственных грантов и конкурсов на разработку и подготовку нормативно-правовых актов, а также не предусмотрено вознаграждение и материальное стимулирование. Кроме того, в законодательстве четко не отражены механизмы правовой защиты интеллектуальной собственности (проекты законов и другие нормотворческие разработки) ученых и специалистов.

8) редко применяется в нормотворческой деятельности такой важный приём как правовой эксперимент. Поэтому осуществление социальноэкономической и политической значимости нормативно-правовых актов по всей стране может приводить к различным финансовым, организационным и духовным неблагоприятным последствиям под влиянием

4 Собрание законодательства Республики Узбекистан 2006 г., № 41, ст. 406; 2014 г., № 20, ст. 222; 2017 г., № 37, ст. 978, Национальная база данных законодательства, 05.01.2018 г., № 03/18/456/0512, 10.01.2018 г., № 03/18/459/0536. 
объективных и субъективных факторов. В то же время цель принятия определенного нормативно-правового акта не полностью достигается.

\section{Совершенствование научно-теоретических и методологических основ нормотворческой деятельности: анализ зарубежного опыта}

Совершенствование научно-теоретических и методологических основ нормотворческой деятельности в стране напрямую связано с изучением и анализом передового опыта развитых государств.

В развитых государствах оценка воздействия актов законодательства (далее - СОВАЗ) является на сегодняшний день устоявшейся и постоянно совершенствующейся практикой. Степень СОВАЗ по их виду и сфере регулирования достаточно неоднородна, но в большинстве стран под СОВАЗ попадают как законы, так и подзаконные акты. Каждое государство имеет собственное приоритетное направление осуществления СОВАЗ. Как правило, наибольшее внимание концентрируется на тех законодательно-правовых актах, принятие которых может оказать влияние на вопросы развития общественного благосостояния (США), малого бизнеса, торговли и конкуренции (Великобритания, Германия, Швеция, Дания), защиты окружающей среды (Австралия, Германия, Норвегия) и т.п. ${ }^{5}$

Анализ актов законодательства - это инструмент, который регуляторные органы используют для прогнозирования и оценки вероятных последствий принимаемых норм.

Это способ организации данных, подтверждающих наличие значительного влияния - как положительного, так и отрицательного - различных альтернатив, которые должны рассматриваться при разработке нормативно-правовых актов. Такой анализ необходим для: получения информации о том, насколько выгоды от принимаемого решения оправдывают необходимые издержки, или определения наиболее эффективной альтернативы из числа возможных вариантов.

Качественный анализ актов законодательства должен включать следующие три основных элемента: заявление о необходимости предлагаемого действия, изучение альтернативных подходов к решению существующей проблемы, и качественную и количественную оценку выгод и издержек от предлагаемого действия и основных альтернатив, которые были выявлены в ходе анализа.

5 См.: Ф. Мухамедов (и др.), Оиенка воздействия актов законодательства: практическое пособие, Ташкент 2015, с. 37-60. 
В большинстве случаев за проведение СОВАЗ отвечают сами регулирующие ведомства, однако при наличии координирующего органа в составе правительства.

В Великобритании оценка воздействия актов законодательства является неотъемлемой частью политического цикла. Для этого в 1998 г. был создан специальный орган при Кабинете Министров - Бюро оценивания регулирующего воздействия (Regulatory Impact Unit), аппарат которого включает госслужащих и несколько экспертных групп:

- экономическую группу;

- группу проведения исследований, включающую экспертов в области государственной политики из госслужащих и частного сектора;

- группу бизнес-регулирования, задачей которой является организация прямого диалога с бизнесом;

- группу государственного сектора, включающую экспертов частного и государственного секторов экономики, целью которой является устранение излишнего государственного вмешательства в экономику, а также мониторинг регулирующей нормативно-правовой базы;

- группа дерегулирования, в задачи которой входит методическое обеспечение процессов оценивания регулирующих актов, а также обеспечения надлежащего обучения служащих ${ }^{6}$.

Нидерланды широко используют модель стандартных издержек (Standard Cost Model), позволяющую определить административное бремя, налагаемое тем или иным законом на бизнес и/или граждан. Консультационный совет по административным барьерам (Adviescollege Vermindering Administratieve Lasten - ACTAL) был создан в 2000 г. Совет оценивает все проекты НПА на предмет избыточного регулирования. В 2010 г. им было подготовлено 11 заключений по существенным законопроектам ведомств. Члены Совета избираются из числа политиков, экономистов и ученых.

Главной задачей Совета является предварительная оценка ожидаемых затрат нормативно-правовых актов, совершенствование нормотворческого процесса, но на этом его полномочия не заканчиваются. ACTAL также может проводить ретроспективную оценку существующего законодательства и предлагать поправки в случае обнаружения устаревших норм. Основными объектами анализа Совета являются законы и подзаконные акты, которые оказывают существенное влияние на развитие государства и общества. Однако ACTAL также может оценивать затраты муниципальных властей на выполнение законов. Помимо этого, Совет оценивает бремя, налагаемое государственными органами или учреждениями друг на друга. Например,

6 Там же, с. 37. 
Министерство образования Нидерландов разрабатывает правила, которым должны следовать все школы, но эти правила могут быть слишком обременительными, т.е. требовать дополнительных затрат или персонала, тем самым увеличивая нагрузку на систему образования страны.

Заключение Совета по законопроектам носит рекомендательный характер, однако является веским аргументом для законодателей. В целях достижения консенсуса ACTAL постоянно контактирует с руководителями политических партий. Заключение публикуется и находится в открытом доступе, и это означает, что на правительство оказывается сильное давление со стороны общественности в случае его нежелания принять к сведению мнение Совета.

Основные причины внедрения СОВАЗ в США были продиктованы:

- необходимостью обоснования федеральными министерствами и ведомствами целесообразности государственного вмешательства;

- потребностью правительства контролировать действия федеральных министерств и ведомств, которым предоставлены полномочия по разработке нормативно-правовых актов;

- необходимостью повышения эффективности нормативно-правовых актов путем введения обязательства по выполнению анализа выгод и издержек.

В основе внедрения СОВАЗ была, с более общей точки зрения, идея, что политики должны принимать обоснованные решения, которые основаны на всех имеющихся доказательствах. В случае Соединенных Штатов, эта идея изначально сочеталась с четким акцентом на необходимость избегать наложения на бизнес ненужных административных нагрузок.

Такой результат мог быть достигнут путем введения обязательства рассчитывать выгоды и издержки, проводить анализ альтернативных вариантов регулирования и обосновать принятие положения с точки зрения «чистой выгоды». Хотя система США остается почти неизменной, первоначальный подход был частично изменен - акцент был перенесен с снижения затрат для достижения лучшего баланса между нормативными затратами и выгодами.

Первые шаги в сфере СОВАЗ сопровождались реформированием механизма управления, принятого администрацией США для разработки нормативно-правовых актов.

СОВАЗ был введен в качестве обязательного процедурного шага при нормотворчестве.

В частности, Закон «Об административных процедурах» ${ }^{7}$ предусматривает, что проекты нормативно-правовых актов, представленные федераль-

7 См.: Национальная база данных законодательства, 09.01.2018 г., № 03/18/457/0525. 
ными органами, подлежат опубликованию в течение заранее обозначенного периода для проведения обсуждений. С 1981 года, документ о проведенной оценке воздействия должен быть прикреплен к проекту нормативноправового акта в качестве пояснительной записки, чтобы позволить заинтересованным сторонам высказывать более структурированные и обоснованные замечания.

Как известно, в национальной практике и в зарубежном опыте круг субъектов нормотворческой деятельности довольно широк. Они зачастую используют различные научно-теоретические и методологические приёмы и средства в нормотворческом процессе, что в свою очередь приводит к неопределённости правовых норм, их разночтению, коллизиям, пробелам и т. д. В развитых государствах накоплен позитивный опыт координации научно-теоретической деятельности в области нормотворчества, который способствует совершенствованию механизмов разработки и принятию отвечающих современным требованиям законов и других нормативно-правовых актов.

Координацию научно-теоретической деятельности в области нормотворчества в Великобритании осуществляет парламентское управление науки и техники (далее - ПУНТ). Эта структура оказывает научно-теоретическую и методическую помощь парламенту в нормотворческом процессе.

ПУНТ - это офис обеих палат парламента, контролируемый Советом депутатов и внешними экспертами, который предоставляет рекомендации по исследованиям, связанным с вопросами государственной политики. Например, консультанты ПУНТ проводят брифинги для отбора научноисследовательских материалов, имеющих отношение к запросам, или оценки доказательств. Его деятельность охватывает широкий круг областей, включая здоровье, биологические науки, физику, инженерные науки, ИКТ, энергетику, окружающую среду и социальные вопросы.

ПУНТ обеспечивает беспристрастное резюме академических и других исследований, делая выводы в политическом контексте для парламентского использования. Они часто принимают форму экспертной оценки получаемой из научных кругов, бизнес сообщества, правительства и третьего сектора.

ПУНТ каждый год проводит ряд мероприятий, которые объединяют парламентариев с ведущими экспертами исследовательского сообщества и институтов гражданского общества.

ПУНТ определяет тенденции в науке, технологии, обществе и политике, анализирует их последствия при принятии законов и других актов для парламента. Данное управление также осуществляет работу со специалистами, 
исследователями в парламенте, которые стремятся узнать больше о нормотворческом процессе и предоставляет им доступные обзоры исследований по разным отраслям науки.

Государственное стимулирование методических разработок в области нормотворчества в Великобритании осуществляет вышеназванное управление.

Исследователи $\mathrm{PhD}$ могут быть спонсированы для проведения научной деятельности обычно в течении трех месяцев работы в Парламентском управлении науки и техники. Некоторые стипендии также открыты для докторантов-исследователей в академических кругах и бизнес сообщества. Эта схема работает с исследовательскими советами, учеными обществами и благотворительными организациями, она также открыта для ученых, работающих в британских вузах над конкретными исследовательскими проектами определяемые парламентом или по своему выбору. Кроме того, Палата общин в партнерстве с Ассоциацией политических исследований (далее АПИ) предлагает академические стипендии для ученых изучающих политические, правовые и социальные проблемы, а также для желающих изучать работу парламента. У стипендиатов есть доступ к парламенту, а также к назначенному куратору в целях оказания помощи в их исследовании.

Государственное стимулирование методических разработок в области нормотворчества в Японии имеет свою специфику. Субъекты, участвующие в нормотворческом процессе в Японии, получают финансовую поддержку со стороны государства. Например, в каждом министерстве имеются отраслевые консультативные органы, в которые привлекаются специалисты соответствующей области, и с ними заключаются контракты с выплатой ежедневной или постоянной заработной платы. Эти финансовые расходы вычитаются из бюджета, утвержденного в начале года.

Кроме того, депутатам и фракциям выделяются специальные средства для разработки законов. Средства выделяются из соответствующих фондов и распределяются среди участников нормотворческой деятельности.

Правительство финансирует различные государственные гранты и фонды исследователям, которые необходимы для нормотворчества.

Координация научно-теоретической деятельности в области нормотворчества в Японии осуществляется структурами, объединяющими исследовательские проекты субъектов участвующих в процессе нормотворчества.

Консультативные органы, созданные в рамках министерств, регулярно регистрируют и публикуют содержание научных дебатов касающихся нормотворчества. Кроме того, согласно статьи 131 Закона о парламенте Японии, в структуре парламента имеется Законодательное бюро. Одной из основных 
задач этого бюро является сбор, систематизация и анализ документов, связанных с нормотворчеством.

Кроме того, в Японии имеется Государственная библиотека парламента, которая также служит поддержкой парламентариев в проведении научноисследовательских работ нормотворчества. Соответствующие отделы библиотеки участвуют в исследованиях, сборе материалов, изучении опыта зарубежных стран, которые имеют непосредственное отношение к нормотворческому процессу.

Серьёзным фактором, оказывающим влияние на подготовку юридических кадров, является правовая система. Особенности романо-германской правовой семьи: верховенство закона в системе источников права, сложная система подзаконных актов, значительная роль кодифицированных законов, особое положение правовой доктрины в процессе толкования права - делают необходимым наличие у правоприменителя достаточной теоретической подготовки. В англо-саксонской правовой семье от юристапрактика не требуется знать основные принципы права, быть знакомым с историческими предпосылками, судебными методами или иметь достаточное представление о взаимоотношениях правовых и других аспектов общественной жизни. Ключевую роль для них играет умение отслеживать, обнаруживать нормативную информацию, содержащуюся в судебном прецеденте, и работать с ней. Таким образом, подготовка юриста не может происходить по некой «идеальной модели», всегда верх будут брать исторические традиции и национальные черты. Однако это не означает полного отсутствия схожих элементов в национальных системах юридического образования.

Подготовка высококвалифицированных специалистов является одним из важных факторов разработки и принятия отвечающим современным требованиям законов и других нормативно-правовых актов, и в целом всего нормотворческого процесса. В этом плане заслуживает внимания положительный опыт развитых государств.

Особый интерес представляет опыт организации системы юридического образования в США, в государстве, где сложилась одна из наиболее эффективных моделей подготовки юристов. Особая правовая система этой страны, традиционно высокий уровень правовой культуры определили важное место юридической профессии в жизни американского общества. Юристы занимают ведущие посты в государственном аппарате, политике, экономике США. Одной специфической чертой юридического образования США является усиление практической направленности процесса обучения: разбор конкретных дел, учебные судебные процессы, работа с юридическими документами. 
Наличие жесткой специализации является одной из важнейших особенностей юридического образования в США. Подобный подход в процессе обучения юристов имеет как плюсы, так и минусы. С одной стороны, из стен американских вузов выходят юристы, получившие хорошую теоретическую и практическую подготовку по выбранной специализации, которые будут востребованы в конкретной сфере деятельности. Но с другой стороны, такая подготовка ограничивает возможности американских юристов, заставляя останавливаться на одной области правоприменения. Такое соотношение специальных и общеобразовательных курсов обусловлено тем, что объем правового регулирования общественных отношений в США достаточно велик. Подготовить квалифицированного специалиста широкого профиля, разбирающегося во многих законодательных сферах, в США просто невозможно. Именно поэтому американская система высшего юридического образования основана на углубленном изучении предметов специализации. В случае, если уже практикующий юрист захочет переквалифицироваться, для этого в американских вузах предусмотрены годичные программы обучения - магистр в области права (Magister's degree in law - LLM).

Так, например, в Германии в нормотворческом процессе особое место занимает подготовка кадров в сфере юриспруденции. В настоящее время в Германии насчитывается около 40 юридических факультетов, входящих в состав государственных университетов. В Германии лидерами в сфере юридического образования считаются Европейский университет Виадрина во Франкфурте-на-Одере, Высшая юридическая школа имени Буцериуса в Гамбурге, университеты Пассау, Байройта и Дюссельдорфа. Однако, в Германии нет отдельных вузов по подготовке кадров именно в сфере нормотворчества.

Во Франции функционирует Институт политических исследований в Париже. Здесь слушатели изучают курсы по подготовке проектов законодательных актов, которые являются одними из составляющих учебного плана. Навыки слушателей развиваются на практике после обучения за счет поставленных задач со стороны практиков, работающих в министерствах и ведомствах. Во время обучения основной уклон делается на юридическую экспертизу, нежели чем на социальные науки. Каждый год примерно 100 госслужащих проходят данный курс.

В Южной Кореи не существует системы подготовки кадров в сфере нормотворчества. Специалисты по юриспруденции готовятся в высших учебных заведениях, то есть в школах права и отбираются в министерство Южной Кореи по вопросам законодательства или в парламент.

Социальное и государственно-частное партнерство в нормотворческом процессе имеет богатый опыт в развитых странах. Так, например, институт 
государственно-частного партнерства в сфере нормотворчества в Германии начал развиваться с 2002 г., после создания так называемых центров государственно-частного партнерства (далее - ГЧП).

После принятия в 2005 г. Закона «Об ускорении внедрения ГЧП», практически во всех округах страны были созданы консалтинговые компании «Партнерства Германии». Кроме Закона «Об ускорении внедрения ГЧП» в Германии к нормативно-правовой базе, обеспечивающей реализацию механизма государственно-частного партнерства, относят закон «О конкурсных ограничениях». Основной целью ГЧП Германии в сфере нормотворчества является повышение благосостояния общества. В свете реализации этой цели, государственные органы Германии являются с одной стороны «заказчиками» законопроектов, с другой - пытаются создать условия благоприятные для инвестирования, играя при этом роль «регулятора». Все это говорит о гармонизации интересов не только государственных структур, но также частного бизнеса и населения страны посредством применения данного механизма. На уровне федеративных земель организационноконсультационную роль играют специально создаваемые группы по развитию проектов государственно-частного партнерства.

Федеральный центр совместно с оперативными группами реализует проектную, координационную, консультационную, а также научно-методическую деятельность. Проектная деятельность заключается в подготовке, организации, а также реализации законопроектов. Стоит отметить, что реализация проектов со стороны центров заключается лишь в создании пилотных проектов, а также предоставлении консультаций частным структурам. Координационная деятельность ГЧП-центров заключается в поддержке институтов, регулирующих деятельность партнерств, а также развитие информационной инфраструктуры, что подразумевает создание информационных баз о консультантах и инвесторах. Кроме того, оперативными группами постоянно проводятся семинары, симпозиумы, конференции, круглые столы, призванные, во-первых, привлечь внимание к нормотворчеству государственночастного партнерства, а во-вторых, дать возможность познакомиться и обменяться опытом между чиновниками и частными лицами, что повышает лояльность обеих сторон к механизму государственно-частного партнерства в сфере нормотворчества.

Еще одной значимой характеристикой института государственночастного партнерства в сфере нормотворчества в Германии является реализация оперативными центрами ГЧП научно-методической деятельности, что подразумевает изучение опыта зарубежных стран в сфере развития нормотворчества. 
Существующая в Германии система социального партнерства дает возможность решать спорные вопросы в законодательстве с помощью разработки законопроектов. Это означает, что разные социальные группы могут участвовать в процессе нормотворчества, в частности в разработке и обсуждении законопроекта. Германская модель социального партнерства в сфере нормотворчества предполагает опосредованное правом взаимодействие между ведущими группами индустриального общества. На общественнопубличном уровне происходит регулируемое правом и организованное на принципах социального партнерства взаимодействие между государством и частным сектором

В Японии нормотворчество осуществляется создаваемыми в соответствии с законом Консультативным советом и Кабинетом Министров Японии, частными консультативными органами. Консультативные органы формируются из представителей следующих сфер деятельности:

1) бизнеса;

2) органов центральной власти;

3) науки;

4) средств массовой информации.

Задачами представителей данных сфер являются отражение мнения каждого слоя населения, обеспечения справедливости в нормотворческой деятельности, отражение знаний специалистов, участвующих в подготовке проекта закона и других нормативно-правовых актов.

В Японии большинство проектов законов разрабатываются в министерствах. Они создают экспертные и рабочие комиссии. Комиссия выдает отчет о своих выводах министерству, которое затем разрабатывает проект закона. После этого законопроект направляется в Бюро законодательства Кабинета министров для изучения его соответствия правилам законодательной техники. После его утверждения Бюро Кабинета министров, официальные лица министерства обсуждают закон с представителями правящей партии. Законопроект обсуждается среди заместителей министров, а затем представляется в Кабинет министров для утверждения, после чего отправляется в парламент. Таким образом, предлагаемый законопроект проходит несколько этапов обсуждения прежде чем его обсудит и примет парламент. Членами парламента инициируется только 20 процентов законопроектов, оставшиеся 80 процентов предлагаются Кабинетом министров.

В Южной Кореи нормотворчество, в частности подготовка проектов законов, осуществляется путём социального партнерства. Например, Сообщество «Зеленых» Кореи (Green Korean group) и другие негосударственные некоммерческие организации участвуют при разработке проектов законов 
в сфере экологии и оказывают позитивное влияние на деятельность Национального собрания Южной Кореи. Национальное собрание и правительство являются субъектами законодательной инициативы.

\section{Выводы}

Исходя из проделанного анализа можно сделать следующие выводы и выдвинуть рекомендации по укреплению научно-теоретической и методологической основы нормотворческой деятельности.

1. Для обеспечения эффективности правового регулирования и высокого качества закона, законотворческая политика должна осуществляться путем совершенствования правотворческой деятельности, повышения технико-юридического качества нормативных правовых актов, уровня профессиональной подготовки субъектов правотворческой деятельности, эффективного применения и толкования права. В настоящее время законотворческий процесс регламентируется многочисленными нормативноправовыми актами, что нередко приводит к дублированию друг друга и к неоправданному затягиванию принятия важных нормативно-правовых актов. В связи с этим необходимо систематизировать многочисленные нормативно-правовые акты, регламентирующие нормотворческую деятельность и принять Кодекс законотворчества.

2. Проведение правового эксперимента по апробации проектов законов является эффективной практикой в законодательстве нашей страны и создает дополнительные возможности для дальнейшего совершенствования нормативно-правовых актов, широкого внедрения в законотворческую деятельность основанного на демократических принципах метода апробации новых правовых актов. В связи с этим необходимо разработать Закон «О правовом эксперименте нормативно-правовых актов».

3. Целесообразно разработать и принять Закон «Об экспертном обеспечении законотворческой деятельности». Принятие данного закона позволит определить порядок проведения экспертного сопровождения всех стадий законотворческого процесса, начиная с законодательной инициативы и до принятия закона, а также мониторинга его исполнения. В этом законе, наряду с другими видами экспертизы проектов нормативно-правовых актов, предусматривается также обязательное проведение научной экспертизы с участием представителей различных областей науки исходя из предмета регулирования нормативно-правового акта. Это послужит важным фактором укрепления научно-методологических основ законотворческой деятельности. 
4. При разработке нормативно-правовых актов необходимо предусмотреть возможные положительные и отрицательные последствия на ближайшую и долгосрочную перспективы, которые могут повлиять на социальноэкономическую и общественно-политическую жизнь общества. В этих целях необходимо разработать четкие научно обоснованные критерии и методы прогнозирования, шире внедрять механизмы мониторинга действующего законодательства и правоприменительной практики как источника прогностической информации для принятия эффективных нормотворческих решений. Кроме того, для повышения эффективности работ в данной сфере, следует включить в круг функциональных обязанностей всех субъектов нормотворчества задачи прогнозирования, а их координацию возложить на Исследовательский институт правовой политики при Министерстве юстиции Республики Узбекистан.

5. Одним из основных инструментов, позволяющих оценить эффективность и качество принимаемых законов и других нормативно-правовых актов, является СОВАЗ. На современном этапе следует разработать научнотеоретическую и методологическую основу СОВАЗ, исходя из международного опыта.

6. Необходимо обратить внимание на упорядочение понятийного аппарата законов и иных нормативно-правовых актов, в связи с чем предстоит провести работу по унификации понятий и терминов, используемых в нормотворческой и правоприменительной деятельности. Целесообразно подготовить типовой Словарь законодательных понятий и терминов, и Унифицированные правила юридической техники на узбекском и русском языках.

\section{Резюме}

В статье рассматриваются научно-теоретические и методологические основы нормотворческой деятельности в Республике Узбекистан и зарубежных странах. Анализируются состояние и проблемы научно-теоретических и методологических основ разработки и принятия нормативно-правовых актов. Автором выдвинуты предложения и рекомендации по укреплению научно-теоретической и методологической основ нормотворческой деятельности. 
Shahzod Alikhonovich Saydullaev

\section{IsSues Improvement of Scientific-Theoretical ANd Methodological Basis of Rule-Making Activity in the Republic of Uzbekistan Against Foreign EXPERIENCE}

The article deals with the scientific-theoretical and methodological foundations of normmaking activities in the Republic of Uzbekistan. The condition and problems of scientifictheoretical and methodological bases of elaboration and adoption of normative-legal acts are analyzed. The author also puts forward proposals and recommendations on strengthening the scientific-theoretical and methodological basis of rule-making activities.

KEY WORDS: rule-making, lawmaking, legislative process, normative-legal acts, prognostication

\section{Библиография}

Yu. G. Arzamasov, Departmental Lawmaking: Current State, Problems of Modernization, «Legal technology» 2012, № 6 .

Yu. G. Arzamasov (ed.), Normography: Theory and Technology of Rulemaking, Moscow 2017.

L. N. Berg, Rulemaking as a Form of Legal Policy, «Law and Politics» 2013, № 11.

T. Kurus, Foreign Experience of the Rule-Making Activities of Local Governments, the Norms Governing their Powers, «Law and Life» 2013, No 10/3.

S. I. Kuzmin, Smart Regulation - in Search of the Golden Mean, «Customs Scientific Journal CUSTOM» 2013, № 1 .

V. I. Radchenko, Monitoring of Law Enforcement. Determination of the Effectiveness of Legal Regulation, «Monitoring of law enforcement» 2014, № 3.

O. Ryaboshapko, T. Chapurko, Citizen Participation in the Development of Regulatory Legal Acts in the Electronic Environment: Problems and Prospects, «Society and Law» 2014, № 2 (48).

N. A. Vlasenko (ed.), Normative Legal Technique, Moscow 2011. 


\title{
Особенности правового регулирования
} общественного контроля

\section{в Российской Федерации на федеральном, региональном и муниципальном уровнях (конституционно-правовой анализ)}

\author{
КЛЮЧЕВЫЕ СЛОВА: \\ Федеральное, региональное, муниципальное законодательство, \\ общественный контроль, Российская Федерация, \\ конституционно-правовой анализ, народ, участие в управлении \\ государственными делами, власть
}

Национальное российское законодательство, составляющее основу конституционно-правовой организации механизма общественного контроля в России, представлено Конституцией Российской Федерации; федеральным законодательством (федеральными конституционными законами, федеральными законами, актами Президента и Правительства страны, федеральных министерств и ведомств); региональным законодательством (конституциями и уставами субъектов Российской Федерации, региональными законами и подзаконными актами); муниципальным законодательством (уставами муниципальных образований и муниципальными нормативно-правовыми актами).

При этом, в рамках федерального, регионального и муниципального законодательства, нормативно-правовые акты, условно, можно классифицировать на следующие подгруппы: 1) регулирующие правовой статус федеральных, региональных и местных органов власти; 2) регулирующие вопросы общественного контроля при формировании органов публичной власти всех уровней; 3) регулирующие вопросы общественного контроля в целом; 4) регулирующие вопросы отдельных аспектов общественного контроля власти (например, экологический общественный контроль, общественный контроль за местами лишения свободы); 5) регулирующие вопросы уча- 
стия некоммерческих организаций в общественном контроле (в частности, профсоюзных, природоохранных); 6) регулирующие вопросы общественного контроля за органами и организациями, осуществляющими полномочия, делегированные органами публичной власти в соответствии с действующим законодательством.

Конституция Российской Федерации не содержит определения понятия общественного контроля, но установила, в частности, что: носителем суверенитета и единственным источником власти в Российской Федерации является ее многонациональный народ, который осуществляет ее непосредственно, а также через органы государственной власти и местного самоуправления (ч. 1 и 2 статьи 3); в Российской Федерации признается идеологическое разнообразие (ч. 1 статьи 13); граждане России вправе объединяться и создавать общественные объединения как разновидность юридических лиц (ч. 4 статьи 13); граждане страны имеют право участвовать в управлении делами государства как непосредственно, так и через своих представителей (статья 32) и обращаться лично, а также направлять индивидуальные и коллективные обращения в государственные органы и органы местного самоуправления (статья 33) ${ }^{1}$.

При этом, право народа на осуществление народовластия и участие в управлении государственными делами основной закон страны ничем не ограничивает, в то время как посягательства любых органов власти и их должностных лиц на принадлежащую народу власть, делегируемую избираемым органам государственной власти и местного самоуправления, преследуются по закону, вплоть до привлечения к уголовной ответственности.

В числе нормативно-правовых актов, регулирующих правовой статус федеральных, региональных и местных органов власти, можно выделить, например, Федеральный конституционный закон «О Правительстве Российской Федерации» от 17.12.1997 № 2-ФК3, который не содержит детального правового регулирования общественного контроля в стране, но в главе 6 закрепляет формы государственного (внутреннего) контроля за деятельностью Правительства России:

1) доверие, недоверие и отказ в доверии Правительству Российской Федерации;

2) ответы членов Правительства Российской Федерации на вопросы членов Совета Федерации и депутатов Государственной Думы;

3) ответы на запросы членов Совета Федерации и депутатов Государственной Думы;

1 См.: Конституция Российской Федерации (принята всенародным голосованием 12.12.1993), «Российская газета» 19.12.1993, № 273. 
4) ответы на письменные обращения комитетов и комиссий палат Федерального Собрания;

5) ежегодные отчеты Правительства Российской Федерации о результатах его деятельности, в том числе по вопросам, поставленным Государственной Думой;

6) предоставление информации об исполнении федерального бюджета 2 .

Таким образом, предусмотренный данным федеральным конституционным законом контроль высшего органа исполнительной власти в стране со стороны палат федерального парламента (Государственной Думы, избираемой населением и Совета Федерации, формируемого избираемыми органами власти субъектов Российской Федерации), позволяет народу осуществлять опосредованный общественный контроль данной ветви власти.

Федеральный закон «О статусе члена Совета Федерации и статусе депутата Государственной Думы Федерального Собрания Российской Федерации» от 08.05.1994 № 3-Ф3, в свою очередь, закрепляет ряд норм, закрепляющих отдельные формы контроля народа за федеральным парламентом России, например, обязывающих депутатов Государственной Думы и членов Совета Федерации отчитываться перед избирателями (народом). В частности, в части 2 статьи 8 предусмотрена обязанность депутатов по рассмотрению обращений избирателей и личному приему граждан, а в части 3 статьи 8 - по информированию избирателей о своей деятельности во время встреч с ними, а также через средства массовой информации 3 .

Это позволяет Федеральному Собранию Российской Федерации, с одной стороны, отчитываться перед избирателями в постоянном режиме, а с другой стороны, получать своевременную информацию о положении дел в стране в части соблюдения, охраны, защиты и исполнения прав, свобод и законных интересов человека и гражданина.

В связи с тем, то федеральный парламент России (его нижняя палата) непосредственно избирается населением и состоит из его представителей, представляет интерес право депутатов по контролю власти: парламентский запрос (статья 13); депутатский запрос (статья 14); приглашение членов Правительства Российской Федерации и других должностных лиц на заседание соответствующей палаты Федерального Собрания Российской Федерации (статья 15); право члена Совета Федерации, депутата Государственной Думы на прием в первоочередном порядке руководителями и другими

2 См.: О Правительстве Российской Федерации: Федеральный конституционный закон от 17.12.1997 № 2-ФКЗ, СЗ РФ. 22.12.1997, № 51, Ст. 5712.

3 См.: О статусе члена Совета Федерации и статусе депутата Государственной Думы Федерального Собрания Российской Федерации: Федеральный закон от 08.05.1994 № 3-Ф3, С3 РФ. 12.07.1999, № 28, Ст. 3466. 
должностными лицами (статья 16); право члена Совета Федерации, депутата Государственной Думы на получение и распространение информации (статья 17) ${ }^{4}$.

Эти формы контроля властного механизма со стороны Федерального парламента (при этом, наполненные реальными полномочиями) существенно дополняют систему общественного контроля в стране.

В свою очередь, Федеральный конституционный закон от 31.12.1996 № 1-ФКЗ «О судебной системе Российской Федерации», закрепляет формы участия народа в отправлении правосудия, а также его контроля за органами судебной власти. Например, в статье 8 предусматривается возможность участия граждан Российской Федерации в осуществлении правосудия в порядке, предусмотренном федеральным законом, в том числе и в виде присяжных и арбитражных заседателей, а в статье 9 - гласность в деятельности судов ${ }^{5}$.

Данные нормы существенно минимизируют коррупционную составляющую в организации и деятельности органов судебной власти и позволяют обществу в режиме реального времени реагировать на избрание мер уголовной ответственности по наиболее тяжким преступлениям, предусмотренным Уголовным кодексом Российской Федерации.

Федеральный закон «Об общих принципах организации законодательных (представительных) и исполнительных органов государственной власти субъектов Российской Федерации» от 06.10.1999 № 184-Ф3, в свою очередь, предусматривает в статье 3.1 ответственность органов государственной власти субъектов Российской Федерации в случае принятия нормативных правовых актов, противоречащих действующему законодательству и повлекших за собой массовые и грубые нарушения прав и свобод человека и гражданина ${ }^{6}$. Данная форма политической ответственности региональных органов государственной власти выступает в роли дополнительной гарантии права народа на осуществление общественного контроля власти.

В свою очередь, Федеральный закон «Об общих принципах организации местного самоуправления в Российской Федерации» от 06.10.2003 № 131-Ф3 в ряде своих статей предусматривает обширные права граждан России на осуществление местного самоуправления и контроль за его органами: возможность проведения местного референдума (статья 22); голосование по

4 См.: Там же.

5 См.: О судебной системе Российской Федерации: Федеральный конституционный закон от 31.12.1996 № 1-ФКЗ «О судебной системе Российской Федерации», СЗ РФ. 06.01.1997, № 1, Ст. 1 .

6 См.: Об общих принципах организации законодательных (представительных) и исполнительных органов государственной власти субъектов Российской Федерации: Федеральный закон от 06.10.1999 № 184-Ф3, С3 РФ. 18.10.1999, № 42, Ст. 5005. 
отзыву депутата, члена выборного органа местного самоуправления, выборного должностного лица местного самоуправления, голосование по вопросам изменения границ муниципального образования, преобразования муниципального образования (статья 24); возможность проведения схода граждан, осуществляющего полномочия представительного органа муниципального образования (статья 25); правотворческую инициативу граждан (статья 26); публичные слушания, общественные обсуждения (статья 28); собрание граждан (статья 29); конференцию граждан (собрание делегатов) (статья 30); обращение граждан в органы местного самоуправления (статья 32); другие формы непосредственного осуществления населением местного самоуправления и участия в его осуществлении (статья 33)7.

Таким образом, следует отметить, что федеральное законодательство, регулирующее вопросы местного самоуправления, содержит более репрезентативные формы прямого общественного контроля за органами местного самоуправления и их должностными лицами, по сравнению с аналогичным контролем федеральных и региональных органов государственной власти.

В числе нормативно-правовых актов, регулирующих вопросы общественного контроля при формировании органов власти, следует выделить, например, федеральные законы «О выборах Президента Российской Федерации» от 10.01.2003 № 19-Ф3, «О выборах депутатов Государственной Думы Федерального Собрания Российской Федерации» от 22.02.2014 № 20-Ф3, предусмотревшие участие в избирательной кампании общественных наблюдателей и наблюдателей от политических партий ${ }^{8}$. Аналогичные формы участия граждан в избирательном процессе предусмотрены на региональном и муниципальном уровнях ${ }^{9}$. Кроме того, представители политических партий и общественных движений входят в состав избирательных комиссий всех уровней (от участковых до Центральной избирательной комиссии Российской Федерации) в качестве их членов с совещательным и решающим голосом.

7 См.: Об общих принципах организации местного самоуправления в Российской Федерации: Федеральный закон от 06.10.2003 № 131-Ф3, С3 РФ. 06.10.2003, № 40, Ст. 3822.

8 См.: О выборах Президента Российской Федерации: Федеральный закон от 10.01.2003 № 19-Ф3, С3 РФ. 13.01.2003, № 2, Ст. 171; О выборах депутатов Государственной Думы Федерального Собрания Российской Федерации: Федеральный закон от 22.02.2014 № 20-Ф3, С3 РФ. 24.02.2014, № 8, Ст. 740.

9 См. подробнее, например: О выборах главы администрации (губернатора) Краснодарского края: Закон Краснодарского края от 03.07.2012 № 2519-КЗ, «Кубанские новости» 08.07.2012, № 126; О муниципальных выборах в Краснодарском крае: Закон Краснодарского края от 26.12.2005 № 966-КЗ [Электронный ресурс]. Режим доступа: http://docs.cntd.ru/document/461608554 (дата обращения: 01.11.2018). 
Участие представителей общественности в избирательном процессе на всех его уровнях позволяет, во-первых, обеспечить законность при проведении выборов и референдумов, минимизировав фальсификации их результатов, во-вторых, осуществлять постоянный общественный контроль за ходом избирательной кампании и кампании по проведению референдума, в-третьих, оперативно информировать общество через средства массовой информации, а также деятельность общественных организаций и движений (включая политические партии) о любых нарушениях политических прав граждан.

В числе нормативно-правовых актов, регулирующих общие вопросы общественного контроля в России, следует выделить федеральные законы «Об основах общественного контроля в Российской Федерации» от 21.07.2014 № 212-Ф310, «Об Общественной палате Российской Федерации» от 04.04.2005 № 32-Ф311, которые содержат наиболее полную правовую регламентацию системы общественного контроля в Российской Федерации.

Они создают в соответствии со статьями 71 и 72 Конституции Российской Федерации, с одной стороны, правовую основу для осуществления общественного контроля в нашей стране на федеральном уровне, а с другой стороны, определяют пределы правового регулирования общественного контроля нормативно-правовыми актами на уровне регионов и муниципальных образований.

На уровне субъекта Российской Федерации (например, Краснодарского края) вопросы общественного контроля урегулированы законами Краснодарского края от 25.12.2015 № 3305-К3 «Об общественном контроле в Краснодарском крае»12, от 03.03.2017 № 3575-К3 «Об Общественной палате Краснодарского края и о внесении изменений в отдельные законодательные акты Краснодарского края» ${ }^{13}$. Данные нормативно-правовые акты приняты на основании федерального законодательства и посвящены формированию и функционированию системы общественного контроля на уровне региона.

Так, Закон Краснодарского края от 25.12.2015 № 3305-К3 «Об общественном контроле в Краснодарском крае» закрепляет систему субъектов

10 См.: Об основах общественного контроля в Российской Федерации: Федеральный закон от 21.07.2014 № 212-Ф3, «Российская газета» 23.07.2014, № 6435 (163).

11 См.: Об Общественной палате Российской Федерации: Федеральный закон от 04.04.2005 № 212-Ф3, С3 РФ. 11.04.2005, № 15, Ст. 1277.

12 См. Об общественном контроле в Краснодарском крае: Закон Краснодарского края от 25.12.2015 № 3305-К3 [Электронный ресурс]. Режим доступа: http://www.garant. ru/hotlaw/krasnodar/690617 (дата обращения: 01.11.2018).

13 См.: Об Общественной палате Краснодарского края и о внесении изменений в отдельные законодательные акты Краснодарского края: Закон Краснодарского края от 03.03.2017 № 3575-К3 [Электронный ресурс]. Режим доступа: http://admkrai. krasnodar.ru (дата обращения: 01.11.2018). 
общественного контроля на территории Краснодарского края (в которую входят, в частности, Общественная палата Краснодарского края, общественные советы при Законодательном Собрании Краснодарского края, при исполнительных органах государственной власти Краснодарского края и органах местного самоуправления в Краснодарском крае, общественные инспекции и группы общественного контроля), определяет их полномочия, а также формы и результаты общественного контроля (общественные проверки, экспертизы, обсуждения $)^{14}$.

Важное значение в организации общественного контроля власти на уровне субъектов Российской Федерации играют общественные советы при региональных органах исполнительной власти (далее также - РОИВ). Так, Е. Г. Дьякова отмечает, что анализ положений об РОИВ в Уральском федеральном округе на 01.04.2016 показал, что основной акцент в них делался на: «обеспечении и оптимизации взаимодействия с гражданским обществом, общественными объединениями/гражданами (такие пункты имеются в положениях 66,6\% общественных советов); экспертизе общественно-значимых нормативно-правовых актов (51,9\%); информировании граждан о деятельности органов власти, при которых создан общественный совет $(45,5 \%)$; выдвижении, обсуждении, обобщении и поддержке гражданских инициатив (31,4\%); повышении открытости и прозрачности деятельности РОИВ $(21,7 \%)\rangle^{15}$. Таким образом, на уровне регионов процессы организации и осуществления общественного контроля предполагают широкое задействование институтов гражданского общества, включая общественные и религиозные организации и движения, а также политические партии.

На уровне муниципальных образований вопросам общего регулирования общественного контроля власти посвящены муниципальные нормативноправовые акты. Например, постановление администрации муниципального образования город Краснодар от 18.08.2010 № 6214 «Об Общественной палате муниципального образования город Краснодар» определяет Общественную палату муниципального образования город Краснодар в качестве формы участия населения в местном самоуправлении, обеспечивающей регулярное и конструктивное взаимодействие граждан, общественных объединений, некоммерческих организаций и органов местного самоуправления муниципального образования город Краснодар в решении наиболее важных

14 См. Об общественном контроле в Краснодарском крае: Закон Краснодарского края от 25.12.2015 № 3305-К3 [Электронный ресурс]. Режим доступа: http://www.garant. ru/hotlaw/krasnodar/690617 (дата обращения: 01.11.2018).

15 Е. Г. Дьякова, Общественные советь при органах исполнительной власти субъектов Федераиии: как выполняется функция общественного контроля, «Дискурс-Пи» 2016, № 2, c. 30-31. 
вопросов экономического и социального развития города, защите прав и свобод граждан, в нем проживающих ${ }^{16}$. При этом, Общественная палата муниципального образования город Краснодар играет и роль информационной площадки, на которой могут быть озвучены результаты мероприятий, проводимых в рамках общественного контроля иными субъектами общественного контроля.

Как справедливо отмечает ряд авторов: «Закон об основах общественного контроля установил систему общественного контроля в России по уровням власти (федеральный, региональный, муниципальный) и отраслевому признаку. Первый вид осуществляется общественными палатами по территориальному признаку, а второй - общественными советами при конкретном органе власти. Однако законодатель фактически создал ситуацию, при которой сегодня во многих муниципальных образованиях не существует механизмов для организации общественного контроля» ${ }^{17}$. Исправление данной ситуации требует доработки федерального законодательства в части закрепления обязанности муниципальных образований по созданию на территории муниципалитетов системы общественного контроля.

Это обстоятельство поддерживает, в частности, Д. С. Михеев, которий отмечает, что «правовая природа местного самоуправления как формы осуществления власти народом диктует требование о создании системы открытого независимого общественного контроля, который должен осуществляться населением, гражданами, общественными объединениями, не находящимися в отношениях подчинения с органами местного самоуправления... посредством чего ... можно достигнуть наибольшей открытости и гласности в работе органов местного самоуправления. Он способен не только представить объективную картину деятельности местной власти, но и вовлечь в механизм проведения общественного контроля население, повысить его информированность о вопросах, решаемых органами местного самоуправления» ${ }^{18}$.

Однако, эффективность системы общественного контроля на муниципальном уровне осложняется тем, что во многих муниципальных образо-

16 См.: Об Общественной палате муниципального образования город Краснодар: Постановление администрации муниципального образования город Краснодар от 18.08.2010 № 6214 [Электронный ресурс]. Режим доступа: http://docs.cntd.ru/document/446219111 (дата обращения: 01.11.2018).

17 См.: Т. Н. Михеева, Е. И. Белоусов, Общественный контроль на муниципальном уровне: анализ новелл законодательства, « HYPERLINK "https://elibrary.ru/contents. asp?id=34074890” Актуальные проблемы экономики и права» 2015, № 2, с. 180.

18 См.: Д. С. Михеев, Обеспечение общественного контроля - ключевое направление в развитии принципа гласности местного самоуправления, «Lex Russica» 2015, T. 101 , № 4, c. 31 . 
ваниях, как правило, отсутствуют нормативно-правовые акты, посвящённые общему правовому регулированию системы общественного контроля. Анализ нормативно-правовой базы на уровне муниципальных образований в Южном и Северо-Кавказском федеральных округах показал на 01.01.2018, что в более $80 \%$ муниципальных образований общественные палаты отсутствуют $^{19}$. Это свидетельствует о том, что, с одной стороны, региональные органы государственной власти не стимулируют создание органов общественного контроля на уровне муниципальных образований, а с другой стороны, об отсутствии денежных средств в муниципальных бюджетах, которые, как правило, носят дотационный характер, на финансирование и поддержку данных субъектов общественного контроля.

В числе нормативно-правовых актов, регулирующих вопросы отдельных аспектов общественного контроля власти в Российской Федерации (например, экологического общественного контроля, общественного контроля за местами лишения свободы), можно выделить, в частности: Федеральный закон «Об охране окружающей среды» от 10.01.2002 № 7-Ф3 (предусмотревший в статье 68 общественный контроль в области охраны окружающей среды (общественный экологический контроль); Федеральный закон «Об общественном контроле за обеспечением прав человека в местах принудительного содержания и о содействии лицам, находящимся в местах принудительного содержания» от 10.06.2008 № 76-Ф3, регулирующий механизм контроля общества над местами лишения свободы и принудительного содержания.

Так, Федеральный закон «Об охране окружающей среды» от 10.01.2002 № 7-Ф3 предусмотрел возможность граждан Российской Федерации индивидуально, либо путем участия в создании и деятельности общественных объединений, осуществлять общественный контроль за деятельностью органов государственной власти и местного самоуправления в области охраны окружающей среды (например, путем выдвижения предложения о проведении общественной экологической экспертизы и участия в ее проведении в установленном порядке; обращения в органы власти и иные организации с жалобами, заявлениями и предложениями по вопросам, касающимся охраны окружающей среды, негативного воздействия на окружающую среду, с получением своевременных и обоснованных ответов; предъявления в суд исков о возмещении вреда окружающей среде и т.п.) $)^{20}$.

19 См. подробнее: А. С. Батаев, Организация общественного контроля в Российской Федерачии на уровне мунищипальньхх образований (на примере Южного и СевероКавказского федеральных округов), Грозный 2018, с. 30-31.

20 См.: Об охране окружающей среды: Федеральный закон от 10.01.2002 № 7-Ф3, С3 РФ. 14.01.2002, № 2, Ст. 133. 
При этом, общественные объединения в целях защиты окружающей среды, осуществляющие общественный контроль, имеют возможность использовать, помимо традиционных его форм, свое право на организацию собраний, митингов, демонстраций, шествий и пикетирований с целью принудить органы публичной власти, а также иные юридические лица, к соблюдению законодательства об охране окружающей среды.

Кроме того, анализ судебной практики, проведённый рядом авторов, показывает возрастающую роль общественных объединений и организаций, осуществляющих общественный контроль, в инициировании судебного разбирательства по рассмотрению вопросов нарушения природоохранного и экологического законодательства, осуществляемого как органами государственной власти и местного самоуправления, так и частными хозяйствующими субъектами ${ }^{21}$.

В свою очередь, Федеральный закон «Об общественном контроле за обеспечением прав человека в местах принудительного содержания и о содействии лицам, находящимся в местах принудительного содержания» от 10.06.2008 № 76-Ф3 предусмотрел создание общественных наблюдательных комиссий как субъектов общественного контроля в области обеспечения прав человека в местах принудительного содержания, а также закрепил достаточно обширный перечень форм общественного контроля (посещение мест принудительного содержания; рассмотрение предложений, заявлений и жалоб лиц, находящихся в местах принудительного содержания, а также иных лиц; подготовку решений по результатам проведения общественного контроля; направление материалов по итогам осуществления общественного контроля в уполномоченные органы государственной власти и местного самоуправления, их должностным лицам, а также в вышестоящие органы общественного контроля; взаимодействие с органами публичной власти, а также иными организациями, включая участие в работе комиссий исправительных учреждений; проведение мероприятий (общественных обсуждений, слушаний) по вопросам своей деятельности) 22 .

Представляется, что данный федеральный закон является удачной формой правового регулирования организации общественного контроля в отдельных

21 См. подробнее, например: О.В. Воронцова, Общественный экологический контроль: отдельные вопросы судебной практики, «Вестник Коми республиканской академии государственной службы и управления. Серия: Государство и право» 2016, № 21, c. $103-109$.

22 См.: Об общественном контроле за обеспечением прав человека в местах принудительного содержания и о содействии лицам, находящимся в местах принудительного содержания: Федеральный закон от 10.06.2008 № 76-ФЗ, С3 РФ. 16.06.2008, № 4, Ст. 2789. 
отраслях государственного управления, и положительный опыт его работы может быть использован и в других отраслях государственного управления.

На уровне субъекта Российской Федерации (например, Краснодарского края) отдельным аспектам общественного контроля власти посвящены законы Краснодарского края от 07.12.2010 № 2124-К3 «Об экологическом мониторинге на территории Краснодарского края», от 23.07.2003 № 608-К3 «Об административных правонарушениях» ${ }^{23}$.

Так, закон Краснодарского края от 07.12.2010 № 2124-К3 «Об экологическом мониторинге на территории Краснодарского края» предусмотрел право граждан и их объединений на осуществление общественного контроля в области экологического мониторинга, в том числе возможность получать экологическую информацию, а также информацию о проводимых мероприятиях в области экологического мониторинга на территории Краснодарского края, вносить предложения в орган исполнительной власти Краснодарского края, уполномоченный в области экологического мониторинга, об организации и осуществлении экологического мониторинга на территории Краснодарского края; оказывать содействие в организации и осуществлении экологического мониторинга ${ }^{24}$. Данный региональный закон убедительно доказывает возможность организации и осуществления общественного контроля в отдельных сферах государственного управления на уровне субъектов Российской Федерации путем объединения усилий общественных организаций и объединений, отдельных граждан для проведения мероприятий общественного контроля.

В числе нормативно-правовых актов, регулирующих вопросы участия некоммерческих организаций в общественном контроле (профсоюзных, природоохранных) можно выделить: Федеральный закон «О профессиональных союзах, их правах и гарантиях деятельности» от 12.01.1996 № 10-Ф3; Федеральный закон «Об охране окружающей среды» от 10.01.2002 № 7-Ф3; Федеральный закон «О политических партиях» от 11.07.2001 № 95-Ф3.

Так, Федеральный закон «О профессиональных союзах, их правах и гарантиях деятельности» от 12.01.1996 № 10-Ф3 закрепляет достаточно широкую систему прав профессиональных союзов на осуществление общественного контроля за соблюдением прав, свобод и законных интересов работников (например, на представительство и защиту социально-трудовых прав и интересов работников; на осуществление профсоюзного контроля за соблюдением законодательства о труде; на защиту интересов работников в органах по рас-

23 См.: Об административных правонарушениях: Закон Краснодарского края от 23.07.2003 № 608-К3, «Кубанские новости» 29.07.2003, № 125.

24 См.: Об экологическом мониторинге на территории Краснодарского края: Закон Краснодарского края от 07.12.2010 № 2124-КЗ, «Кубанские новости» 13.12.2010, № 218. 
смотрению трудовых споров), а также деятельностью любых работодателей 25. При этом, законодатель гарантирует права профсоюзов на осуществление деятельности по общественному контролю за рядом обязанностей работодателей по созданию условий для осуществления деятельности профсоюзов.

В свою очередь, Федеральный закон «О политических партиях» от 11.07.2001 № 95-Ф3 предоставляет широкие полномочия политическим партиям в России по осуществлению широкомасштабного общественного контроля, в том числе, путем: участия в выработке решений органов государственной власти и органов местного самоуправления; участия в выборах и референдумах; использования государственных и муниципальных средств массовой информации, в том числе и на безвозмездной основе; свободного распространения информации о своей деятельности и т.д. ${ }^{26}$ При этом, политические партии в соответствии с действующим законодательством выведены из числа объектов общественного контроля, но обладают значительными возможностями (а парламентские партии - в том числе и финансовыми средствами) для поддержки субъектов общественного контроля любого уровня.

В числе нормативно-правовых актов, регулирующих вопросы общественного контроля за юридическими и физическими лицами, осуществляющими полномочия, делегированные органами публичной власти в соответствии с действующим законодательством, можно выделить, например: Федеральный закон от 03.12.2011 № 392-Ф3 «О зонах территориального развития в Российской Федерации и о внесении изменений в отдельные законодательные акты Российской Федерации», Федеральный закон от 29.12.2014 № 473-Ф3 «О территориях опережающего социально-экономического развития в Российской Федерации».

Например, Федеральный закон от 29.12.2014 № 473-Ф3 «О территориях опережающего социально-экономического развития в Российской Федерации» предусмотрел обязанность по включению в состав наблюдательного совета территории опережающего социально-экономического развития представителей территориальных объединений (ассоциаций) организаций профсоюзов для осуществления общественного контроля за соблюдением резидентами территории опережающего социально-экономического развития действующего законодательства, а также прав, свобод и законных интересов граждан ${ }^{27}$. Кроме

25 См.: О профессиональных союзах, их правах и гарантиях деятельности: Федеральный закон от 12.01.1996 № 10-Ф3, С3 РФ. 15.01.1996, № 3, Ст. 148.

26 См.: О политических партиях: Федеральный закон от 11.07.2001 № 95-ФЗ, С3 РФ, 16.07.2001, № 29, Ст. 2950.

27 См. подробнее, в частности: О территориях опережающего социально-экономического развития в Российской Федерации: Федеральный закон от 29.12.2014 № 473-Ф3, СЗ РФ. 05.01.2015, № 1 (часть 1), Ст. 26. 
того, существование территории опережающего социально-экономического развития может быть в любой момент прекращено по решению Правительства Российской Федерации, если, например, в ходе мероприятий общественного контроля будет установлено, что этого требует необходимость охрани жизни и здоровья граждан, охрана окружающей среды, обеспечение обороны страны и безопасности государства и т.п.

Таким образом, федеральное, региональное и муниципальное законодательство образуют единое правовое поле, способствующее организации и осуществлению общественного контроля в различных областях государственного и муниципального управления, а также в части соблюдения прав, свобод и законных интересов граждан, а также их объединений.

Однако, на региональном и местном уровнях зачастую отсутствуют нормативно-правовые акты, регулирующие вопросы общественного контроля, а также посвящённые созданию и деятельности общественных палат низового уровня, что диктует необходимость их дальнейшего совершенствования.

\section{Резюме}

Полноценная реализация на практике конституционного принципа народовластия требует постоянного совершенствования института общественного контроля в Российской Федерации, выступающего, с одной стороны, в качестве гарантии реальности права народа на осуществление народовластия, а с другой стороны, механизма, препятствующего узурпации власти, ее незаконного присвоения, а также осуществления не в интересах граждан страны.

Система правового регулирования общественного контроля власти в России представлена несколькими группами нормативно-правовых актов национального законодательства. Настоящая статья посвящена исследованию федерального, регионального и муниципального законодательства в области регулирования общественного контроля в Российской Федерации.

В исследовании использовался ряд научных методов, в частности: сравнительноправовой; оценки; классификации.

В работе проведен сравнительный анализ нормативно-правовых актов, способствующих организации и функционированию системы общественного контроля в Российской Федерации, дана их авторская классификация.

Это позволило провести анализ нормативно-правовых основ механизма общественного контроля в Российской Федерации, определив их место, роль и значимость в организации системы общественного контроля в нашей стране. 
Vitaly Viktorovich Goncharov

\section{Features of Legal Regulation of Public Control in the Russian Federation at the Federal, Regional and Municipal Levels (Constitutional and Legal Analysis)}

Full implementation of the constitutional principle of democracy in practice requires continuous improvement of the institution of public control in the Russian Federation, acting, on the one hand, as a guarantee of the reality of the people's right to exercise democracy, and on the other hand, the mechanism that prevents the usurpation of power, its misappropriation, as well as the implementation is not in the interests of the citizens of the country.

The system of legal regulation of public control of power in Russia is represented by several groups of normative legal acts of national legislation. This article is devoted to the study of federal, regional and municipal legislation in the field of regulation of public control in the Russian Federation.

The study used a number of scientific methods, in particular: comparative legal; assessment; classification.

The paper presents a comparative analysis of legal acts that contribute to the organization and functioning of the system of public control in the Russian Federation, their author's classification.

This made it possible to analyze the regulatory framework of the public control mechanism in the Russian Federation, determining their place, role and importance in the organization of the public control system in our country.

KEY WORDS: federal, regional, municipal, legislation, public control, Russian Federation, constitutional and legal analysis, people, participation in the management of public affairs, power

\section{Библиография}

A. S. Bataev, Organization of Public Control in the Russian Federation at the Level of Municipalities (on the Example of the Southern and North Caucasus Federal Districts), Grozny 2018.

D. S. Mikheev, Ensuring Public Control is a Key Direction in the Development of the Principle of Publicity of Local Self-Government, «Lex Russica» 2015, V. 101, № 4.

T. N. Mikheeva, E.I. Belousov, Public Control at the Municipal Level: an Analysis of Legislation Novels, «Actual problems of economics and law» 2015, № 2.

O. V. Vorontsova, Public Environmental Control: Selected Issues of Judicial Practice, «Komi Bulletin of the Republican Academy of Public Administration and Management. Series: State and Law» 2016, № 21. 


\section{Конституция 1993 г. и местное самоуправление в Российской Федерации}

КЛЮЧЕВЫЕ СЛОВА:

Конституции Российской Федерации, местное самоуправление, государственное управление, публичная власть, централизация политической системы

Местное самоуправление в Российской Федерации в самом общем виде регламентируется Конституцией 1993 г., 25-летие которой достаточно широко отмечалось российской юридической общественностью в декабре 2018 г. Парадокс, однако, состоит в том, что хотя в текст Конституции и были включены достаточно позитивные и либеральные положения касательно местного самоуправления, они сослужили последнему не очень хорошую службу, поскольку были во многом оторваны от реальности и не были сбалансированы с отечественными традициями (выражаясь современным языком) территориальной организации публичной власти. А ведь если маятник раскачивать в одну сторону (в данном случае излишнего либерализма), он в итоге может достаточно резко качнуться и в противоположную, что и произошло в первое, и особенно во второе, десятилетие XXI века.

В основу конституционного регулирования местного самоуправления в Российской Федерации был положен во многом устаревший подход к указанному институту (базировавшийся преимущественно на концепции либерально-демократического государства XIX в.) как к феномену, противостоящему государственному управлению. Именно это во многом предопределило низкую эффективность всей системы управления на местах.

Главный недостаток российского законодательства в области местного самоуправления носил концептуальный характер. В отечественном праве к числу местных органов традиционно относились представительные 
и исполнительные органы краев и областей. Российское же законодательство 90-х гг. прошлого века вывело края и области из системы местных органов, придав им качества субъектов федерации, в то время как само местное самоуправление было выведено за пределы государственного механизма. В итоге получилось, что российское государство заканчивалось на крае, области, а далее начиналось нечто непонятное. При этом имело место отождествление государственной и негосударственной форм местного самоуправления, абсолютизация определенных самоуправленческих начал, реально функционирующих на уровне улицы, дома, микрорайона, и их распространение на систему местного самоуправления в целом.

Одна из ключевых норм Конституции РФ 1993 г,, регулирующих местное самоуправление, содержится в ст. 12, где устанавливается, что «органы местного самоуправления не входят в систему органов государственной власти» ${ }^{1}$. Данная формулировка была затем воспроизведена в п.1 ст.1 Федерального закона “Об общих принципах организации местного самоуправления в Российской Федерации” 1995 г. В итоге местное самоуправление было как бы окончательно пущено в “свободное плавание”, лишившись гарантированной поддержки со стороны государства.

Российское конституционно-правовое законодательство также отличал не всегда оправданный акцент на «самоорганизационных» аспектах местного самоуправления, да и закрепленная на федеральном уровне общая модель местного самоуправления не была в полной мере воспринята в ряде субъектов РФ (особенно в республиках). Правотворчество последних в течение определенного времени не вполне соответствовало федеральному законодательству, что приводило к избыточному разнообразию организационных форм на местах.

Представляется, что лицам, в свое время разрабатывавшим концепцию местного самоуправления и влиявшим на принятие конкретных решений, для адекватной оценки ситуации, возможно, не хватило общетеоретических, компаративистских подходов, понимания особенностей функционирования современного государства. Применяемые на практике знания порой черпались преимущественно из курсов «советского государственного права», «советского строительства», «научного коммунизма». На волне конъюнктуры тех лет все делалось зачастую как бы наоборот, со знаком «минус», без учета отдельных позитивных моментов, связанных с функционированием «системы Советов», таких, например, как обеспечиваемая данной системой быстрота и согласованность работы всех ее звеньев, наличие

1 Конституция Российской Федерации (РФ), URL: http://www.constitution.ru (дата обращения: 18.12.2018). 
организационно-правовых механизмов привлечения населения к решению текущих задач. Вместо постепенной трансформации Советов в представительные органы современного типа применялись революционные, «таранные» методы, разрушавшие в конечном итоге российскую государственность и ее образ в глазах населения.

Следует отметить и определенный «демократический романтизм», свойственный переходному периоду от социализма к постсоциалистической государственнности, стремление максимально защитить права практически заново учреждаемого института местного самоуправления, оградить его от чрезмерного влияния со стороны государственных структур. Подобная ситуация была характерна и для целого ряда других постсоциалистических государств, также стремившихся наделить местное самоуправление максимально широкими полномочиями и в то же время приблизить его к гражданам.

Фактически закрывались глаза на противоречивость и взаимную несовместимость некоторых поставленных задач, поскольку все это компенсировалось «мощной верой в местное самоуправление в качестве своеобразного противоядия централизованному государству и института, посредством которого люди могли бы взять под контроль свою собственную жизнь и регенерировать и возродить образуемые ими сообщества» ${ }^{2}$. В итоге на волне демократизации и идеи местного самоуправления, поддержанной конституционными судами, в целом ряде постсоциалистических государств было образовано слишком большое количество мелких территориальных единиц, отстаивавших свои права, но не способных должным образом оказывать услуги населению.

Так, в Чехии функционирует 6244 общины (муниципалитета), многие из которых являются достаточно мелкими. В среднем в общине проживает 1644 жителей, а средний размер ее территории - 12,7 кв. км. После перехода к демократии в 1990 г. число общин увеличилось вдвое, поскольку многие поселения решили сформировать свои собственные муниципалитеты в рамках открывшихся новых возможностей. Подобные решения «были не только продиктованы теми финансовыми преимуществами, которые дает статус муниципалитета, но и явились реакцией на насильственное укрупнение муниципалитетов при социалистическом режиме» ${ }^{3}$. Согласно имею-

2 A. Coulson, A. Campbell (ред.), Local Government in Central and Eastern Europe: The Rebirth of Local Democracy, London 2008, c. 4.

3 M.J. Goldsmith, Е. С. Page (ред.), Changing Government Relations in Europe: From Localism to Intergovernmentalism, London 2010, c. 31. 
щейся статистике количество общин на территории Чехии было сокращено с 11459 в 1950 г. до 4104 в $1988^{4}$.

Фрагментация местного самоуправления после перехода к демократии резко ослабила его административные возможности и снизила эффективность оказываемых населению услуг. Показательно, что почти $10 \%$ чешских общин представляют собой небольшие сельские поселения, в которых проживает менее 100 жителей. При этом почти в 60\% общин проживает менее 500 жителей 5 . Теперь уже правительству демократической Чехии пришлось стимулировать межмуниципальную интеграцию. В 2000 г. был принят Закон № 128 «Об общинах», удвоивший число жителей, требуемых для создания муниципалитета (с 500 до 1 тыс.) $)^{6}$.

Аналогичным образом в Венгрии число общин с собственными органами управления увеличилось с 1600 до $3174^{7}$ (во многом за счет выделения новых общин из состава уже имеющихся), что также явилось своеобразной компенсацией местным сообществам за присущие бывшему социалистическому режиму централистские тенденции и насильственное укрупнение общин в 70-е гг. XX в. ${ }^{8}$ В итоге Венгрия вообще получила одну из наиболее фрагментированных систем муниципального управления в Европе. В среднем на территории венгерской общины проживает около 1300 человек ${ }^{9}$. В целях борьбы с фрагментацией в 1994 г. были приняты поправки к Закону LXV 1990 г. «О местном самоуправлении», запрещающие создание новых общин, в которых бы проживало менее 100 жителей ${ }^{10}$.

Большое количество мелких общин, неспособных должным образом оказывать услуги населению, характерно и для Словакии и рассматривается «как одна из преград на пути рационального общественного развития» ${ }^{11}$. В 1950 г. здесь функционировали 3444 общины, и при этом на территории общины в среднем проживало 1029 человек. К 1989 г. число общин сократилось до 2 694, а среднее число жителей увеличилось до 1963 . После всех изменений, связанных с демократизацией и образованием независимого

4 См.: Р. Swianiewicz (ред.), Consolidation or Fragmentation? The Size of Local Governments in Central and Eastern Europe, Budapest 2002, c. 17.

5 См.: Там же.

6 См.: Zákon o obcích (obecní zřízení), URL: https://www.zakonyprolidi.cz/cs/2000-128. (дата обращения: 20.12.2018).

7 См.: М. J. Goldsmith, Е. C. Page (ред.), Changing Government Relations ..., c. 112, 115.

8 В Венгрии число общин было сокращено с 3021 в 1962 г. до 1364 в 1988. См.: Р. Swianiewicz (ред.), Consolidation or Fragmentation? ..., с. 17.

9 См.: Там же, с. 45.

10 Целый ряд общин, образованных в 1990 г., из-за демографического кризиса уже опустились ниже этой планки, при этом в ряде общин число жителей, имеющих право голоса, не превышает 20.

11 P. Swianiewicz (ed.), Consolidation or Fragmentation ..., c. 117. 
словацкого государства, число муниципалитетов резко возросло - до 2825 . К началу XXI в. на территории Словакии функционировали 2882 общины, включая 138 муниципалитетов со статусом города. При этом в более чем в двух третях муниципалитетов проживало менее 1000 жителей, а в 123 менее $100^{12}$.

В 2001 г. в целях борьбы с фрагментацией были внесены поправки в словацкий Закон № 369 «Об общинном устройстве» 1990 г. ${ }^{13}$, согласно которым новые общины должны представлять собой целостные территориальные единицы с населением не менее 3 тыс. жителей.

Возвращаясь непосредственно к российской проблематике, следует отметить, что эффективность местного самоуправления в РФ (особенно в конце 80-х - первой половине 90-х гг. прошлого века) снижалась также в силу ошибочного проецирования логики функционирования и взаимоотношений центральных законодательных и исполнительных органов на местный уровень, стремления построить местное самоуправление исключительно на основе системы «сдержек и противовесов». Как, однако, свидетельствует зарубежный опыт, чем ниже уровень власти, тем менее выраженным бывает разделение властей, которое обычно нарастает по мере движения вверх по вертикали. Законодательство должно было бы быть в большей мере ориентировано на то, чтобы глава местной администрации осуществлял властные полномочия совместно с представительным органом в единой «упряжке» местного самоуправления. Разделение властей на муниципальном уровне должно было бы проявляться в основном лишь в размежевании полномочий между представительным органом и администрацией.

Заложенный в российском праве подход к местному самоуправлению как к некой публичной, но в то же время не государственной власти, с одной стороны, способствовал превращению органов местного самоуправления в фактически безвластные институты, а с другой - ослаблял контрольные полномочия вышестоящих властей по отношению к местному самоуправлению. Поиск же субъектами РФ своих подходов к местному самоуправлению (вплоть до его фактической отмены) осуществлялся в условиях «такого уровня дезинтеграции российской конституционно-правовой системы, когда параллельное и зачастую взаимоисключающее правотворчество Федерации и ее субъектов фактически перестало поддаваться действенному контролю и систематизации со стороны центральных властей» ${ }^{14}$.

12 См.: Там же, с. 113.

13 См.: Zákon č. 369/1990 Zb. o obecnom zriadení, URL: http://www.zakonypreludi.sk/ zz/1990-369 (дата обращения: 21.12.2018).

14 И. А. Умнова, Конституционные основы современного российского федерализма, Москва 1998, с. 7. 
Отсутствие в тексте Конституции РФ адекватных финансовых гарантий местного самоуправления также можно отнести к числу пробелов в указанной области. В итоге наблюдалась практически повсеместная нехватка финансовых ресурсов для надлежащего осуществления органами местного самоуправления своих функций. Провозглашаемая в условиях хронического безденежья и нищеты самостоятельность муниципальных органов зачастую способствовала лишь дискредитации идеи местного самоуправления в глазах населения.

Несбалансированность отношений в области местного самоуправления проявлялась и в игнорировании отдельными муниципальными образованиями более широких самоуправленческих и государственных интересов, абсолютизации законодательных положений о самостоятельности муниципальных образований, приводившей к волюнтаризму в процессе принятия решений. Борьба с подобным волюнтаризмом в 90-х гг. XX в. затруднялась ограниченностью спектра возможного воздействия государства на местное самоуправление, невключенностью последнего во властную вертикаль. Лишь в августе 2000 г. были приняты изменения и дополнения в Федеральный закон "Об общих принципах организации местного самоуправления в Российской Федерации”, которые предусмотрели возможность роспуска местных представительных органов и отрешения от должности глав муниципальных образований в случае принятия ими нормативно-правовых актов, противоречащих федеральным и региональным законам.

Достаточно противоречивым представляется конституционное регулирование территориальной организации местного самоуправления. Согласно ч. 1 ст. 131 Конституции РФ, «местное самоуправление осуществляется в городских, сельских поселениях и на других территориях с учетом исторических и иных местных традиций». Данное положение нашло свое развитие в Федеральном законе «Об общих принципах организации местного самоуправления в Российской Федерации», согласно которому местное самоуправление осуществляется на территории муниципальных образований, основным признаком которых является наличие «муниципальной собственности, местного бюджета и выборных органов местного самоуправления» (п. 1 ст. 1).

Подобный подход позволял в определенной степени увязать систему муниципальных образований с существующим административно-территориальным устройством (и поэтому он предпочтительнее подхода с позиций так называемого «поселенческого принципа»). Муниципальное образование, однако, могло быть, а могло и не быть административно-территориальной единицей, а одно лишь наличие административно-территориальной единицы само по себе не влекло в обязательном порядке осуществления в ее границах местного самоуправления. Организация местного самоуправления в рамках 
административно-территориальных единиц, таким образом, фактически перестала быть обязательной нормой. Из числа территорий местного самоуправления формально не могли быть исключены лишь городские и сельские поселения. Вопрос же о признании муниципальными образованиями (т.е. территориями, в пределах которых осуществляется местное самоуправление) иных территорий (на тот период времени - районов, уездов, сельских округов и т. п.) находилось в исключительном ведении субъектов Федерации, и здесь могли иметь место различные подходы.

Не самым оптимальным представляется и конституционное регулирование компетенции местного самоуправления. В Конституции Российской Федерации (ст. 132), устанавливается, что в компетенцию местного самоуправления входят вопросы местного значения, а также отдельные государственные полномочия, которые могут передаваться законом органам местного самоуправления.

Определение решаемых органами местного самоуправления вопросов как «вопросов местного значения» было включено в российское законодательство не в последнюю очередь для того, чтобы подчеркнуть самостоятельность местного самоуправления и его отделенность от государственной власти. Опыт местного самоуправления в странах современного мира, однако, свидетельствует о том, что зачастую бывает сложно выделить сугубо локальные функции местных органов, так же, как и вообще нельзя провести четкую границу между функциями государственного управления и местного самоуправления. Многие функции, выполняемые органами местного самоуправления, вытекают из задач, поставленных центральными властями. Реализуемые муниципальными органами полномочия имеют местное значение лишь в том плане, что они осуществляются на конкретной территории соответствующими субъектами местного самоуправления. На деле же большинство решаемых местными властями вопросов есть лишь продолжение на определенной территории государственной политики в конкретных сферах (образование, здравоохранение, экология, социальное обеспечение и т. п.).

Однозначно определить, какими именно вопросами должны заниматься местные власти, вообще не представляется возможным. Ведь в действительности большинство решаемых ими проблем имеют как местное, так и общенациональное звучание, и ограничение компетенции местных органов лишь сугубо локальными, второстепенными вопросами означало бы отведение местному самоуправлению второстепенной роли.

Достаточно противоречивым является и конституционный институт государственных полномочий, которыми могут наделяться органы местного самоуправления. В 90-е годы прошлого века данный институт не имел четкого законодательного урегулирования и практически не работал. Прини- 
мавшиеся органами государственной власти после вступления в действие Конституции РФ акты зачастую вообе не разграничивали полномочия государственного и местного значения. Хотя многие полномочия, возлагавшиеся отраслевыми законами как Федерации, так и ее субъектов (а иногда и отдельными актами исполнительных органов государственной власти) на местные органы, по действующему законодательству могли бы быть классифицированы как «государственные полномочия». При этом зачастую игнорировалось требование ст. 133 Конституции РФ об одновременной передаче органам местного самоуправления соответствующих финансовых ресурсов для покрытия расходов, вызванных необходимостью выполнения возложенных обязанностей. Ведь в случае использования термина «государственные полномочия» органам государственной власти пришлось бы передавать местному самоуправлению соответствующие материальные и финансовые средства, которых у них могло и не быть в наличии.

С учетом вышесказанного, вполне можно было бы обратиться к опыту некоторых зарубежных демократий, подразделяющих полномочия органов местного самоуправления на обязательные и факультативные (добровольные). В число обязательных полномочий обычно входят жизненно важные для местных сообществ вопросы, которым придается общегосударственное значение: поддержание общественного порядка и безопасности, организация дошкольного, начального, а иногда и среднего образования населения (включая содержание школьных зданий, детских садов, специализированных учреждений для детей-инвалидов), территориальное планирование, управление землепользованием, противопожарная охрана, водоснабжение, канализация, сброс сточных вод, утилизация коммунальных отходов, контроль за загрязнением окружающей среды, здравоохранение, эксплуатация санитарных учреждений, обеспечение населения электричеством, газом и теплом, освещение и уборка улиц, регулировка уличного движения, содержание дорог, коммунальных кладбищ, организация ритуальных услуг, развитие торговли и рынков и т.П.

Государство устанавливает минимальные стандарты обязательных услуг, следит за их выполнением, гарантируя тем самым определенную защиту населения в случае неэффективности действий или бездействия местных властей.

Факультативные же полномочия реализуются органами местного самоуправления по своему усмотрению, в зависимости от реальных финансовых возможностей. К ним чаще всего относятся различные виды обслуживания населения и организации его досуга: коммунальное жилищное строительство, ремонт домов, создание муниципальных коммунально-бытовых предприятий, организация коммунального общественного транспорта, поддержание 
и обслуживание социально незащищенных слоев населения, назначение из муниципальных средств доплат к пенсиям и пособиям, организация зрелищных мероприятий, развитие художественной самодеятельности, обеспечение работы спортивных площадок, бассейнов, театров, библиотек, обустройство прилегающих к ним территорий и т.п. В ряде стран некоторые из указанных полномочий могут относиться к обязательным, и наоборот, отдельные полномочия, перечисленные выше в качестве обязательных, могут входить в число факультативных. Стандарты факультативных услуг, как правило, не устанавливаются сверху, а разрабатываются непосредственно на местах.

При этом может выделяться и так называемая «делегированная» (порученная) компетенция органов местного самоуправления, близкая по функциональному значению к обязательным полномочиям, т.е. компетенция, передаваемая им вышестоящими властями. В ФРГ, например, полномочия органов местного самоуправления делятся на три группы: добровольные, обязательные и порученные (делегированные). К третьей группе относятся вопросы, которые не считаются непосредственно местными и образуют так называемую «делегированную сферу влияния». В нее входят полномочия, связанные с проведением выборов, вопросы гражданства, защита от стихийных бедствий и др. ${ }^{15}$ Возложение на общину каких-либо государственных задач в каждом конкретном случае осуществляется по законодательному акту земли (субъекта германской федерации - А. Ч.), которым в обязательном порядке должны быть урегулированы необходимые финансовые вопросы.

Весьма интересен японский опыт в сфере делегированных полномочий. Законодательство Японии предусматривает два вида делегированных полномочий ${ }^{16}$. Первый вид делегируется муниципальному совету как юридическому лицу. Местные власти обязаны осуществлять данные полномочия, принимая необходимые нормативные акты в порядке обычной процедуры. Другой вид делегированных полномочий именуется “агентскими функциями”. Центральные власти обычно передают их какому-либо местному административному органу, чаще всего главе исполнительной власти соответствующего территориального подразделения (функции также могут делегироваться школьным советам, комитетам по общественной безопасности и иным административным органам на местах). Осуществляя эти полномочия, местный орган функционирует исключительно в качестве агента государства под строгим контролем со стороны соответствующего министра центрального правительства (на уровне региональной единицы - префектуры)

15 См.: Местное самоуправление в Германии (на примере Положения об общинах земли «Баден-Вюртемберг»), Москва 1996, с. 29.

16 Revised Local Autonomy Law, URL: http:// www.nippon.zaidan.info/seikabutsu/1999/00168/ mokuji.htm (дата обращения: 17.12.2018). 
или же губернатора префектуры (на уровне муниципалитета). За реализацию агентских функций административный орган несет ответственность не перед местным советом, а перед соответствующей контролирующей инстанцией, и представительный орган не вправе принимать какие-либо решения по данным вопросам ${ }^{17}$.

Отдельные недостатки российского законодательства в области местного самоуправления были несколько скорректированы принятием в 2003 г. нового Федерального закона «Об общих принципах организации местного самоуправления в Российской Федерации» и внесением последующих изменений в российское законодательство ${ }^{18}$. Из текста Федерального закона был изъят ряд положений, лишенных практического смысла и имевших преимущественно идеологический характер. Была утверждена роль местного самоуправления в качестве одной из форм осуществления народом своей власти, полноправного элемента единого механизма публичной власти, функционирующего на демократической основе (гарантированной на федеральном уровне) и обладающего своей собственной, четко установленной компетенцией и ответственностью. При этом было смягчено противопоставление государственной власти и местного самоуправления, которое, как уже отмечалось, на практике не столько помогало, сколько вредило местному самоуправлению, делая его фактически безвластным и способствуя его сворачиванию в целом ряде субъектов Российской Федерации.

В дальнейшем маятник, однако, качнулся в другую сторону. В условиях фактического сворачивания федерализма, централизации политической системы и нарастания в ее рамках авторитарных тенденций местному самоуправлению, по-прежнему лишенному финансовой самостоятельности, становилось все труднее сохранять свою самобытность в качестве самостоятельного уровня управления, как это принято в развитых демократических государствах. Не случайно даже в достаточно осторожной и корректной отечественной юридической литературе период после 2003 г. был определен как период «унификации организации местного самоуправления, ограничения компетенции субъектов Российской Федерации в вопросах правового регулирования и контроля за осуществлением местного самоуправления» 19 .

17 О механизме реализации агентских функций см. подробнее: R. J. Samuels, The Politics of Regional Policy in Japan, Princeton 1983, c. 43.

18 См.: Федеральный закон от 06.10.2003 № 131-Ф3 (ред. от 05.04.2013 с изменениями, вступившими в силу 19.04.2013) «Об общих принципах организации местного самоуправления в Российской Федерации», URL: http://www.zakonprost.ru/zakony/osamoupravlenii (дата обращения: 29.11.2018).

19 Ю. Л. Шульженко (ред.), Теория и практика Российского самоуправления, Москва 2017, c. 156. 
В настоящее время определенные «точечные изменения» ныне действующей Конституции в указанной области теоретически могли бы быть проведены, если бы они способствовали изменению взгляда на местное самоуправление как на чужеродный элемент в системе власти и управления российского государства. Вполне логично было бы более четко закрепить на конституционном уровне место и роль местного самоуправления в качестве низового звена территориальной организации публичной власти в Российской Федерации, обладающего автономией и самостоятельностью.

При этом следовало бы обратить внимание и на принцип субсидиарности, получивший широкое распространение в странах Европейского Союза. Отношения между различными уровнями власти, включая распределение полномочий между ними, строятся таким образом, чтобы эффективно решались общественно значимые задачи, соблюдались права человека. Вышестоящие властные уровни не вмешиваются в дела местного самоуправления, пока муниципальные органы справляются с ними. Если же по каким-либо причинам власти того или иного уровня перестают справляться со своими функциями и не в состоянии обеспечить права и законные интересы граждан, то органы власти другого уровня, используя установленные правовыми нормами процедуры, в рамках своей компетенции и своих возможностей берут на себя решение необходимых задач. Налицо, таким образом, не изолированное функционирование властей различных уровней, а их взаимная дополняемость ради достижения общего блага. При этом, естественно, не допускается незаконное смешение компетенции, произвольное вмешательство одних органов власти в дела других органов.

В данном отношении можно было бы обратиться к опыту конституционной реформы 2001 г. в Италии, включившей указанный принцип в ст. 118 Конституции 1947 г.20 Правда, принцип субсидиарности в данной статье в соответствии с общеевропейскими канонами был сбалансирован принципом пропорциональности (адекватности), согласно которому «децентрализация функций должна иметь место лишь тогда, когда местные власти доказывают свою способность реализовывать новые полномочия должным образом» ${ }^{21}$.

В заключение следует отметить, что посредством лишь точечных конституционных изменений право населения на местное самоуправление едва ли может быть в полной мере защищено. Для того чтобы местное самоуправление функционировало более эффективно, необходима глубинная реформа всей системы политических институтов, которая была бы направлена на

20 См.: Конституиия Итальянской Республики, [в:] Б.А. Страшун (ред.), Избранные конституции зарубежных стран, Москва 2011.

21 M. J. Goldsmith, Е. С. Page (ред.), Changing Government Relations in Europe..., c. 130. 
децентрализацию власти и более действенное обеспечение системы разделения властей в Российской Федерации как по горизонтали, так и по вертикали.

Централизация, конечно же, придает внешнюю упорядоченность делам общества и обеспечивает возможность достигнуть определенного единообразия проявлений человеческой активности. При этом, однако, следует помнить, что когда «возникает необходимость привести в движение глубинные силы общества или же резко ускорить его развитие, централизованная власть незамедлительно теряет свою силу» ${ }^{22}$. В случае объединения индивидуальных сил с общественными, как это происходит в рамках локальных коллективов, порой удается добиться того, чего “самая сконцентрированная и самая деятельная власть была бы не в состоянии сделать" 23.

\section{Резюмe}

В статье анализируются особенности конституционного регулирования местного самоуправления в Российской Федерации. По мнению автора, в основу такого регулирования был положен несколько устаревший подход к указанному институту, в рамках которого местное самоуправление рассматривалось как феномен, противостоящий государственному управлению, что, в конечном итоге ослабило его позиции и определило достаточно низкую эффективность всей системы управления на местах.

Закрепленная на федеральном уровне общая модель местного самоуправления не была в полной мере воспринята в ряде субъектов РФ, а отсутствие в тексте Конституции РФ адекватных финансовых гарантий местного самоуправления определило практически повсеместную нехватку финансовых ресурсов для надлежащего осуществления органами местного самоуправления своих функций. Провозглашаемая в условиях хронического безденежья самостоятельность местных органов власти зачастую способствовала лишь дискредитации идеи местного самоуправления в глазах населения.

Некоторые недостатки конституционного регулирования в области местного самоуправления были несколько скорректированы текущим законодательством, а также отдельными решениями Конституционного Суда РФ. Тем не менее, в условиях нынешней централизации российской политической системы и нарастания в ее рамках авторитарных тенденций местному самоуправлению становится все труднее сохранять свою самобытность в качестве самостоятельного уровня управления.

22 А. де Токвиль, Демократия в Америке, Москва 1994, с. 86.

23 Там же, с. 89. 
Alexander I. Cherkasov

\section{Constitution of 1993 and Local Self-Government in the Russian Federation}

The article deals with particular features of the constitutional regulation of local self-government in the Russian Federation. The author argues that this regulation was based on somewhat outdated approach towards the mentioned institution, within the framework of which local self-government was considered to be a phenomenon opposing the state administration, and this in the final result has weakened its positions and determined sufficiently low efficiency of the whole local administrative system.

The general model of local self-government fixed at the federal level was not perceived in full in a number of Federation subjects, and the lack of adequate financial guarantees of local self-government determined nearly general shortage of financial resources necessary for proper fulfillment of local self-government's functions. Local authorities' independence proclaimed in the conditions of the chronic lack of money often only helped to discredit the idea of local self-government in the eyes of the population.

Certain shortcomings of constitutional regulation in the field of local self-government have been slightly corrected by the current legislation as well as by some decisions of the Constitutional Court of the Russian Federation. Nevertheless in the conditions of present centralization of the Russian political system and the strengthening of authoritarian tendencies within its framework local self-government finds it increasingly difficult to preserve its identity as an independent level of administration.

KEY WORDS: Constitution of the Russian Federation, local self-government, state administration, public power, centralization of the political system

\section{Библиография}

A. Coulson, A. Campbell (ред.), Local Government in Central and Eastern Europe: The Rebirth of Local Democracy, London 2008.

M. J. Goldsmith, Е. C. Page (ред.), Changing Government Relations in Europe: From Localism to Intergovernmentalism, London 2010.

R. J. Samuels, The Politics of Regional Policy in Japan, Princeton 1983.

Yu. L. Shulzhenko (ред.), Theory and Practice of the Russian Government, Moscow 2017.

P. Swianiewicz (ред.), Consolidation or Fragmentation? The Size of Local Governments in Central and Eastern Europe, Budapest 2002.

I. A. Umnova, Constitutional Foundations of Modern Russian Federalism, Moscow 1998. 
Андрей Валерьевич Гавриков

ORCID: 0000-0002-6500-1042

\section{Политические партии Республики Беларусь и Республики Польша (политико-правовой аспект становления)}

КЛЮЧЕВЫЕ СЛОВА:

политическая партия, политическая либерализаџия, перерегистрация политических партий, модернизация политической системы, многопартийная политическая система

Новым политическим событием постсоветских государств стала многопартийность и, соответственно, институционализация нового социальнополитического института - политической партии. Для сравнения законодательной базы нами выбрано два постсоветских государства:

1) Республика Беларусь, которая непосредственно входила в Союз Советских Социалистических Республик и является членом Евразийского экономического союза (с 1 января 2015 г.) и с 2 апреля 1997 г. имеет статус союзного государства по отношению к Российской Федерации.

2) Республика Польша, которая не входила в состав Союза Советских Социалистических Республик, но находилась в советской системе политических отношений, а после распада социалистической системы тесно интегрировалась с западной Европой и США. С 12 марта 1999 г. стала членом НАТО и 1 мая 2004 г. вступила в Евросоюз.

Политическая партия это один из главнейших институтов представительной демократии, который объединяет интересы различных категорий граждан. Роль политических партий, как представительного института, отмечается в Конституции Республики Беларусь 1994 г. (с изменениями и дополнениями, принятыми на республиканских референдумах 24 ноября 1996 г. и 17 октября 2004 г.). В соответствии со статьей 5 Конституции Республики Беларусь, «политические партии, другие общественные объединения, действуя в рамках Конституции и законов Республики Беларусь, 
содействуют выявлению и выражению политической воли граждан, участвуют в выборах» ${ }^{1}$. В Республике Польша также отмечается важная роль политической партии как представительного института. В соответствии со статьей 4 Конституции, «политические партии образуются на основе принципов добровольности и равенства прав граждан в целях оказания влияния демократическими методами на формирование политики государства».

Свою политическую институционализацию политические партии Беларуси начали еще в Белорусской Советской Социалистической Республике, когда проводилась либерализация политического режима и консолидация неформальных общественных объединений, которые быстро политизировались и оказывали значительное влияние на общественно-политическую жизнь в стране.

Плюрализм, гласность, экономический упадок, политическая нестабильность, национально-культурный «ренессанс» пошатнули позиции Коммунистической партии Советского Союза и привели к появлению и институционализации, как политической силы, неформальных общественных объединений (молодежных, музыкальных, исторических, художественных, творческих). Они быстро политизировались и объединялись в более широкие и массовые организации «Народные фронты», и в большинстве своем переходили на позиции политической оппозиции к КПСС 2 .

К 1988 г. под давлением этих неформальных организаций и либерализации политического режима Верховным Советом БССР было принято решение придать им статус формальных общественных объединений, которых насчитывалось к тому моменту около 200 (все эти организации являлись протопартийными структурами). В СССР в не правовом поле заявили о своей деятельности партии «Демократический Союз» и «Либеральнодемократическая партия Советского Союза». Однако, о их деятельности в БССР не сохранилось никаких источников.

В Польской Народной Республике (ПНР) в отличии от БССР (где была однопартийная политическая система) кроме коммунистической (Польской объединенной рабочей партии (ПОРП) осуществляли свою деятельность: Объединённая крестьянская партия, Демократическая партия, так же была представлена парламентская оппозиция - Ассоциация Знак. Это отличало однопартийную БССР от многопартийной ПНР. Однако реальное партийное строительство в современной Польше было положено созданием неза-

1 Конституция Республики Беларусь: с изм. и доп., принятыми на респ. референдумах 24 нояб. 1996 г. и 17 окт. 2004 г., Минск 2016.

2 А. В. Гавриков, Некоторые аспекты формирования политической системы Pеспублики Беларусь: генезис политических партий 1990-1995 г2., «Весн. Гродзенскага дзяржаўнага ўніверсітэта імя Янкі Купалы. Серыя № 1» 2018, том 10, с. 137. 
висимого самоуправляемого профсоюза «Солидарность»: на базе которого институционализировались новые партии не марксистко-ленинского типа ${ }^{3}$.

В отличии от ПНР в БССР до 1990 г. доминирующую роль занимала КПСС-КПБ. Законодательство страны в этот период не предусматривало регистрации иных политических партий, кроме как КПСС (КПБ), роль которой была определена Конституцией СССР 1977 г. «Руководящей и направляющей силой советского общества, ядром его политической системы, государственных и общественных организаций является Коммунистическая партия Советского Союза. КПСС существует для народа и служит народу» ${ }^{4}$. Доминирующая роль КПБ и ее монополия в политическом поле так же не давала возможности правовой институционализации других политических партий в стране.

В 1989 г. 25 мая на 1 съезде народных депутатов СССР выделилось две противостоящих группы: сторонников умеренной перестройки во главе с Михаилом Горбачевым и сторонников радикальных изменений во главе с Борисом Ельциным. После проведения акции прямого действия и 200 тысячного митинга в Москве за отмену 6 статьи Конституции ${ }^{5}$, Правительство вынуждено было пойти на политические уступки и 14 марта 1990 г. был принят закон «Об учреждении поста Президента СССР и внесении изменений и дополнений в Конституцию СССР» ${ }^{6}$. Все эти политические изменения в Москве руководство БССР воспринимало в ожидательной позиции. В стране росли антикоммунистические настроения и усиливалась национальная и демократическая ориентированность электората. Это выразилось в создании в 1988г. Белорусского народного фронта (БНФ) «Адраджэнне».

Белорусский народный фронт «Адраджэнне» - общественно-политическое движение конца 1980-х - начала 1990-х годов, выступающее за переустройство политической системы и возрождение белорусской нации на принципах демократии и гуманизма, развитие национальной культуры. В конце перестройки движение выдвигало требования государственной независимости Республики Беларусь.

3 А. В. Гавриков, Правовое регулирование создания и деятельности политических партий Беларуси и Польши (сочиально-политический анализ), [в:] А. В. Касович (отв. ред.), Белорусская государственность: истоки, становление, развитие (IX-XXI вв.): материаль Респ. науч.-теорет. конф., Минск, 29 июня 2017 г., Минск 2017, с. 116.

4 Канстытуиыя нашай дзяржавы (1919, 1927, 1937, 1978, 1994). офіиыяльный тэкст, Мінск 2011, с. 200.

5 РИА Новости. Россия сегодня. Отмена 6-й статьи Конституции СССР о руководящей роли КПСС. Справка. [Электронный ресурс]. Режим доступа: https:/ria.ru/spravka/ 20100314/213855855.html (дата обращения: 05.08.2018).

6 Закон СССР от 14 марта 1990г. № 1360-1. «Об учреждении поста Президента и внесении, и дополнении в конституцию (Основной Закон) СССР, Ведомости СНД и ВС СССР 1990, № 12, Ст. 189. 
Важным импульсом трансформации политической системы БССР стала редакция 6 и 7 статьи Конституции СССР и БССР (которые предусматривали возможность регистрации политических партий альтернативных КПСС), а также принятие нормативно-правовых актов, которые давали возможность регистрировать политические партии в стране. Эти изменения фактически санкционировали появление в БССР многопартийности.

В ПНР к началу 1990 годов происходили более стремительные законодательные изменения под давлением общественности и политической оппозиции, возглавляемой профсоюзом «Солидарность». В стране росли антикоммунистические настроения и под влиянием профсоюзного движения Солидарность в стране начался курс на демократизацию и декоммунизацию. 28 июля 1990г. был принят закон «О политических партиях». Политическая партия определена в нем как «добровольная организация, выступающая под определенным названием, ставящая целью участие в политической жизни страны, оказывая демократическими методами влияние на формирование политики государства либо осуществления публичной власти» ${ }^{7}$.

В результате политической борьбы, которая проходила между усиливающейся оппозицией во главе с Лехом Валенсой и ослабленной Польской объединённой рабочей партией была установлена договоренность, которая предусматривала, что «65\% мест в Сейме - нижней палате польского парламента, гарантировались для партийно-правительственной стороны, а оставшиеся 35\% мест - были предметом конкуренции. Согласно соглашению была создана также верхняя палата парламента - Сенат, в котором $100 \%$ мест избирались на основе конкуренции и политического плюрализма. Результаты выборов 4 июня 1989 года были положительными для оппозиции - она выиграла все $35 \%$ мест в Сейме, за которые велась борьба, а также 99\% мест в Сенате». К октябрю 1990 г. было зарегистрировано 154 партии.

Многопартийность - политическая система, при которой в стране могут вести политическую борьбу две и более политических партий, осуществляя свою политическую борьбу на основе действующего законодательства. Первыми нормативно-правовыми актами, регламентирующими создание и деятельность политических партий в Республике Беларусь стали: Постановление Верховного Совета Республики Беларусь от 28 июля 1990 г. № 222-XII «О регистрации общественных объединений в Белорусской Советской Социалистической Республике» и Постановление № 255 Совета министров БССР

7 А. Липинский, Политические партии и партийная система в условиях посткоммунизма. Казус Польши, [Электронный ресурс]. Режим доступа: https://cyberleninka. ru/article/v/politicheskie-partii-i-partiynaya-sistema-v-usloviyah-postkommunizma-kazuspolshi (дата обращения: 01.10.2018). 
«Об утверждении Временного положения о порядке образования и деятельности общественных объединений граждан в Белорусской Советской Социалистической Республике», которые наделяли политические партии юридическим статусом ${ }^{8}$.

Однако в законодательстве Республики 1990-1995 гг. еще не присутствовали. Подтверждением этому может быть интервью, данное начальником Управления по делам общественных объединений Министерства юстиции Беларуси Михаилом Сухининым газете Андрея Климова в 1994 г. На вопрос: «Не возникает ли каких-то особых недоразумений во взаимоотношениях управления с зарегистрированными партиями и объединениями? Был дан ответ: «К сожалению, возникают, и, как правило, в силу двух причин. В первую очередь, из-за пробелов в законодательстве. Бывает, нарушение есть, а мы не можем применить санкции. Во-вторых, по причине незнания лидерами партий действующих документов, регламентирующих деятельность общественных объединений» ${ }^{9}$. Таким образом, политическая система Беларуси находилась в стадии первой политической трансформации 1990-1995 гг., для которой было характерно становление законодательства, регулирующего деятельность политических партий, и их стремительный количественный рост.

В 1990-1994 гг. для регистрации политической партии в исследуемых странах предъявлялись не высокие требования: число учредителей не менее 100 человек (в Республике Беларусь) и не менее 15 человек (в Республике Польша); уплата государственных пошлин в размере 10 минимальных окладов (Беларусь) и отсутствие уплаты (Польша), а также чтобы партия была представлена пропорционально в регионах. В период роста политической активности населения - это не высокий законодательный порог, что в свою очередь позволило зарегистрировать партии разной политической ориентации. В Республике Беларусь - от Национально-демократической партии Белоруссов(членами, которой могли стать только люди, идентифицирующие себя белорусами) до Славянский Собор «Белая Русь» (партия, которая стояла на идеологии панславизма). В Республике Польша партии к 1990-1991 гг. создавались на основе расколовшейся «Солидарности» на идеологиях:

8 Постановление Верховного Совета Республики Беларусь от 28 июля 1990 г. № 222-ХІІ «О регистрации общественных объединений в Белорусской Советской Социалистической Республике» [Электронный ресурс]. Режим доступа: http://pravo.levonevsky.org/ bazaby09/sbor91/text91416.htm (дата обращения: 08.08.2018). Постановление № 255 Совета министров БССР «Об утверждении Временного положения о порядке образования и деятельности общественных объединений граждан в Белорусской Советской Социалистической Республике» [Электронный ресурс]. Режим доступа: http://pravo. levonevsky.org/sbor91/text91416.htm (дата обращения: 08.08. 2018).

9 «Газэта Андрэя Клімава» 1994, № 3. Палітычныя партыі ў Беларусі. 
- правых,

- христианско-демократических,

- консервативно-национальных,

- либеральных,

- центристов.

ПОРП после ХІ съезда перешла на идеологию левоцентристов и преобразовалась в партию «Социал-демократия Республики Польша» (СДРП), после чего в стране политический спектр был представлен от крайне правых до крайне левых. Польское законодательство унифицировалось и к 1993 г. в стране были введены пороги в парламент: для партии - 5\%, партийной коалиции $-7 \%$. При пропорциональной избирательной системе партии становились массовыми и насчитывали от 5 тыс. до 150 тыс. человек.

В Республике Беларусь в это время количественные показатели и электоральная поддержка партий оставалась невысокой. Белорусским социологом И. В. Котляровым, работавшим на базе Академии наук БССР, в книге «Партии в политической жизни Беларуси (социолого-политологический анализ)» даются следующие данные. «Социологические исследования, проведенные в октябре-ноябре 1990 г. в Беларуси, показали, что 0,7\% процента опрошенных отдавали предпочтение новым партиям республики, и 3,3\% населения их поддерживало» ${ }^{10}$, что свидетельствует о том, что электорат только начинал обращать внимание на новый политический институт.

Период 1990-1996 гг. был охарактеризован как в Республике Беларусь, так и в Республике Польша, как усиление политической борьбы между левыми и правыми. В политической борьбе левые партии в Беларуси получали все большую поддержку электората, а в Польше наоборот правые партии все больше оказывали влияние в представительном органе власти. Появляющиеся партии выстраивали свою деятельность и уставы, исходя именно из данных позиций, а электорат находился в состоянии «политического маятника» готовый поддержать ту политическую силу, которая решит социально-экономические проблемы.

Важным событием для становления политических партий в Республике Беларусь стало принятие 5 октября 1994 г. Верховным Советом Республики Беларусь 12 созыва Закона «О политических партиях». Он должен был упорядочить, а также регламентировать деятельность политических партий в политическом поле страны. В Законе впервые дается чёткое определение понятия «политическая партия», рассматриваются права политических партий, финансирование партий и контроль над их деятельностью. Закон предусматривал увеличение минимального количества членов партии с 100

10 И. В. Котляров, Социология политических партий, Минск 2011, 730 с. 
до 500 человек ${ }^{11}$. Это не было значительным препятствием при регистрации новых и перерегистрации существующих политических партий в период с 1995 по 1999 гг.

Политические партии первой политической трансформации являлись важным социально-политическим институтом. Парламентская компания 1995 г. несмотря на то, что Верховный Совет был реформирован, явилась триумфом для белорусской многопартийной политической системы.

В Верховном Совете XIII созыва были представлены:

- Партия коммунистов Белорусская - 44 депутата;

- Аграрная партия - 34 депутата;

- Партия народного согласия - 8 депутатов;

- Объединённая гражданская партия - 8 депутатов;

- Белорусская социал-демократическая Громада - 2 депутата;

- Партия всебелорусского единства и согласия - 2 депутата;

- Белорусская крестьянская партия - 1 депутат;

- Белорусское патриотическое движение - 1 депутат;

- Республиканская партия труда и справедливости - 1 депутат;

- Белорусская партия труда - 1 депутат;

- Белорусская народная партия - 1 депутат;

- Либерально-демократическая партия - 1 депутат.

В Верховном Совете ХІІІ созыва были образованы следующие партийнопарламентские фракции:

- Аграрная фракция (46) - депутаты от Аграрной партии и ее поддерживающие депутаты;

- Фракция ПКБ (44) - депутаты Партии коммунистов Белорусской;

- Социал-демократическая фракция (18) - депутаты ПНС, БСДГ, ПВЕС, БПТ;

- Фракция «Гражданское действие» (18) - ОГП и сочувствующие;

- Партийные фракции включали в себя 2/3 депутатского состава Верховного Совета ${ }^{12}$.

В 1995 г. для упорядочивания деятельности политических партий было принято решение о политической перерегистрации партий. Решение о перерегистрации было принято Кабинетом Министров Республики Беларусь

11 О политических партиях [Электронный ресурс]: Закон Респ. Беларусь, 5 окт. 1994 г., № 3266-ХІІ, ЭТАЛОН. Законодательство Республики Беларусь / Нац. центр правовой информ. Респ. Беларусь, Минск 2017.

12 А. В. Гавриков, Становление многопартийности в Республике Беларусь (конеи 20-начало 21 в.), «Вес. Нац. акад. Навук Беларусі. Сер. Гуманіт. Навук.» 2018, Т. 63, № 1 , c. 35 . 
«О политических партиях», постановление от 3 февраля 1995 г. № 76, Перерегистрацию прошли около $58 \%$ организаций, а также политических партий ${ }^{13}$.

Переход от парламентской модели к президентской существенно повлиял на развитие партийного строительства в стране. Период второй политической трансформации (1995-1999 гг.) белорусских партий характеризуется нестабильностью белорусской многопартийности. Это связано с парламентским кризисом Верховного Совета и его роспуском, расколом и объединением, реорганизацией партий, что было вызвано усилением политической борьбы между сторонниками Президента и его курса, а также политической оппозицией.

В Республике Польша к 1997 г. происходила либерализация регулирования деятельности политических партий. Закон «О политических партиях» от 1997 г. внес определенные новации по снижению порога регистрации политических партий. Сокращалась численность инициативной группы граждан с 15 до 3 человек. В качестве обязательного элемента была предусмотрена поддержка инициативы со стороны 1 тыс. граждан, подтвержденная их подписями. Подача заявки на регистрацию является правом, а не обязанностью партии. Закон различает зарегистрированные (т.е. имеющие статус юридического лица) и незарегистрированные партии.

К 1 января 1998 г., в Республике Беларусь была зарегистрирована 41 политическая партия, но не все проявляли достаточную политическую активность и участие в политической борьбе. Для дальнейшего урегулирования политической деятельности политических партий Президентом был принят Декрет от 13 июля 1999 г. № 26 «О внесении изменений и дополнений в Декрет от 26 января 1999 г. № 2», который увеличивал численность учредителей политических партий до 1000 учредителей и вносил дополнительные изменения в правовое поле деятельности политических партий ${ }^{14}$.

По причинам несоответствия документов, несвоевременной их подачи, недостаточного количества учредителей, бойкота перерегистрации и др., перерегистрацию в 1999-2000 гг. в Беларуси прошли только 18 политических партий. Это было по-разному воспринято различными политическими лагерями.

13 Е. П. Гросс, Институциионализация общественньхх обьединений Республики Беларусь, «Весці Нацыянальнай Акадэміі навук Беларусі. Серыя гуманітарных навук» 2015, c. $47-52$.

14 Декрет Президента Республики Беларусь от 13 июля 1999 г. № 26 «О внесении изменений и дополнений в Декрет Президента Республики Беларусь от 26 января 1999 г. № 2» [Электронный ресурс]. Режим доступа: http://laws.newsby.org/documents/dekretp/ dek00126.htm (дата обращения: 10.09.2018). 
В Республике Польша «Закон о политических партиях» детально регламентирует процесс подготовки партией документов к регистрации. В случае каких-либо неточностей в представленных материалах, суд дает партии срок на их устранение, который не может превышать трех месяцев. С момента внесения партии в Реестр она приобретает юридическую правоспособность. Учет политических партий носит открытый характер. Каждому предоставлено право (на платной основе) на ознакомление в суде с копиями статутов партий. Для эффективности контроля за деятельностью партий на них возлагается обязанность незамедлительного уведомления суда обо всех изменениях в статуте партии, месте ее нахождения, составе руководящих органов, а также имущественных обязательствах партии. Нарушение этих предписаний либо неустранение указанных судом нарушений в течение трех месяцев ведет к исключению партии из Реестра.

Польское законодательство закрепляет принцип открытости источников финансирования политических партий. Имущество партии складывается из членских взносов (так называемых внутрипартийных средств), даров, наследств и завещаний в ее пользу, доходов от ее имущества, а также от поступлений из государственного бюджета. Закон закрепляет право политических партий на дотации и субвенции из бюджета. Дотации распределятся в соответствии с полученным количеством голосов.В Беларуси нет прямого финансирования политических партий. Источниками денежных средств и иного имущества политической партии, союза могут являться:

- вступительные и членские взносы;

- поступления от проводимых в уставных целях мероприятий;

- доходы от использования имущества, издательской деятельности, распространения печатных изданий и публикаций;

- пожертвования и дарения;

- иные источники, не запрещенные законодательством.

Члены политической партии, союза не имеют прав на имущество, в том числе на денежные средства политической партии, союза.

Существенные различия между странами в избирательной системе: в Польше выборы проходят по пропорциональной системе, в Республике Беларусь - по мажоритарной.

К числу факторов, повлиявших на содержание современного польского избирательного законодательства, следует отнести и новое международноправовое положение Польши, ставшей с мая 2004 г. членом Европейского Союза. В ходе подготовительного этапа была проведена сложнейшая работа по унификации польского законодательства. В избирательном законодательстве это проявилось не только в учете европейских стандартов и избира- 
тельных технологий, но и в Законе «Положение о выборах в Европейский парламент» от 23 января 2004 г.

Данный Закон стал завершающим элементом действующей в Польше системы избирательного законодательства. Следует отметить, что избирательное законодательство в последние 10-15 лет развивается весьма динамично. Практически каждые парламентские выборы, проведенные в период III Республики Польша, базировались на новых либо кардинально измененных избирательных предписаниях.

В Республике Польша действуют идеологические ограничители на законодательном уровне. «Запрещается существование политических партий и иных организаций, обращающихся в своих программах к тоталитарным методам и практике деятельности нацизма, фашизма и коммунизма, а также тех, программа или деятельность которых предполагает или допускает расовую и национальную ненависть, применение насилия с целью захвата власти или влияния на политику государства либо предусматривает засекречивание структур или членства» ${ }^{15}$.

В отличии от польского законодательства в белорусском идеологические ограничители запрещают создание партий, которые насильственными методами пытаются изменить конституционный строй (не упоминая конкретной идеологии). «Запрещается создание и деятельность политических партий, а равно других общественных объединений, имеющих целью насильственное изменение конституционного строя либо ведущих пропаганду войны, социальной, национальной, религиозной и расовой вражды».

Таким образом, политические партии в обеих странах прошли значительные изменения в период своего становления, что было обусловлено изменениями государственного строительства независимых стран, а также изменениями их законодательной базы, регламентирующей деятельность партии. Непосредственное влияние на развитие данного института в Республике Беларусь и Республике Польша имела их интеграционная политика и избирательная система страны. Стоит заметить, что законодательство Республики Польша в отношении политических партий более динамичное, чем в Республике Беларусь, что в свою очередь обусловлено большей активностью польских политических партий.

15 А. Липинский, Политические партии и партийная система в условиях посткоммунизма. Казус Польши, [Электронный ресурс]. Режим доступа: https://cyberleninka. ru/article/v/politicheskie-partii-i-partiynaya-sistema-v-usloviyah-postkommunizma-kazuspolshi (дата обращения: 01.10.2018). 


\section{РеЗЮME}

В статье рассматривается становление и развитие политических партий как социально-политического института в Республике Беларусь и Республике Польша. Проводится компаративный анализ правового регулирования политических партий (в исторической ретроспективе) и становления правового ценза в регистрации и деятельности политических партий. В хронологической последовательности рассматриваются основные этапы усовершенствования законодательства в отношении политических партий как одной страны, так и другой. Уделяется внимание законодательным фильтрам и барьерам деятельности политических партий в данных странах, а также законодательного стимулирования их деятельности.

\section{Andrey Valerievich Gavrikov}

\section{Political Parties of the Republic of Belarus and the Republic of Poland (Political and Legal Aspect of Formation)}

The article discusses the formation and development of political parties as a socio-political institution in the Republic of Belarus and the Republic of Poland. A comparative analysis of the legal regulation of the activities of political parties (in historical retrospect) and the formation of legal qualifications in the registration and activities of political parties are carried out. The chronological sequence considers the main stages of the improvement of legislation in relation to political parties both in one country and in another. Attention is paid to the legislative barriers to the activities of political parties and their role in the institutionalization of this socio-political institution.

KEY WORDS: political party, political liberalization, re-registration of political parties, modernization of the political system, multi-party political system

\section{Библиография}

A. V. Gavrikov, Some Aspects of the Formation of the Political System of the Republic of Belarus: the Genesis of Political Parties in 1990-1995, " Spring. Grodno dyarzhavnaga vniversiteta imya Yanka Kupala» 2018, Series № 1, tom 10.

A. V. Gavrikov, The Formation of a Multiparty System in the Republic of Belarus (the End of 20-beginning of the 21 th Century), «Weight. Nat. Acad. Sciences of Belarus. Ser. Humanity. Sciences» 2018, T. 63, № 1.

I. V. Kotlyarov, Party in the Political Life of Belarus (Sociological and Political Analysis), Minsk 1993.

I. V. Kotlyarov, Sociology of Political Parties, Minsk 2011. 


\title{
Конституционное право Европейского союза как объект научных исследований 1
}

\author{
КЛЮЧЕВЫЕ СЛОВА: \\ конституциионное право, Европейский союз, учебник, \\ научные исследования
}

\section{Введение}

В чем заключается цель изложения конституционного права Европейского союза?

Целью изложения конституционного права Европейского союза должно быть получение студентами теоретических знаний и формирование у студентов навыков понимания актуальных проблем теории и практики конституционного права Европейского союза, выработки умения диагностики и выражения конституционных проблем Европейского союза, их анализ, формулирование выводов, предложения их решения, равно как аргументирования в их пользу. Другими словами, вопрос касается предоставления студентам знаний из области конституционного права Евросоюза и компетенций в применении положений конституционного права Европейского союза в процессе изменения самого конституционного права Европейского союза.

1 Текст был составлен в рамках программы Jean Monnet Chair Nr. 575172 (Erasmus + ) ,Teaching the European Transnational Constitutionalism Inside and Outside the EU/TETC". 


\section{Как представляются задачи лекции?}

Определенной таким образом цели, достижение которой осуществляется с помощью лекций по конституционному праву Европейского союза, необходимо подчинить поставленные перед ней задачи.

Должны быть определены следующие четыре задачи:

1) формирование у студентов понимания значения теоретических исследований в решении правовых проблем конституционного права Европейского союза;

2) знание актуальных вопросов, касающихся принципов создания и применения права Европейского союза;

3) выработка у студентов аналитических навыков, т.е. способностей самостоятельного анализа процессов государственного устройства, существующих в рамках Европейского союза;

4) овладение студентами навыков ведения дискуссии на темы, касающиеся проблематики конституционного права Европейского союза.

Реализация определенных таким образом целей требует дискурсивного представления конституционных вопросов, выявления их внутренней сложности, возможных последствий разного рода, в том числе непредусмотренных законодателем и нежелательных для него. На основании анализа учебника студент должен осознавать, что конституционное право Европейского союза не является чем-то постоянным, в своей сути сформированным, как, например, конституция Соединенных Штатов с 1787 г., а напротив - подвержено динамичным изменениям. В данном процессе даже рамки государственного устройства, выраженные в договорах Европейского союза, в том числе в Лиссабонском договоре, не являются неизменными. В течение всего времени они вызывают сомнения, различные возражения и замечания, включая также вопросы о необходимости их реконструкции.

Создание учебника связано с методологическими проблемами. Одна из них касается выделения основных характеристик конституционного права Европейского союза, которые могут влиять на его понимание и оценку вытекающих из них последствий.

Какой методологический подход следует принять при написании учебника по конституционному праву Европейского союза? В данном аспекте самым целесообразным, по моему мнению, является подход, традиционный для изучения конституционного права, т.е. рассмотрение конституционного права Европейского союза с помощью общепринятой терминологии: как государственное устройство, то есть фундамент организации Европейского союза. Аналогично государственному праву, говоря о конституционном праве, обычно подразумеваем государственное устройство, то есть основу 
организации данного государства. Европейское право имеет целостный характер.

Его предметом является государственное устройство и функционирование Европейского союза. Но, несомненно, необходимо подчеркнуть, что это не единственный исследовательский подход, равно как и не новейший научный подход. Как известно, данный вопрос вызывает многочисленные споры среди исследователей конституционного права Европейского союза. Они предлагают различные новые теоретические конструкции по исследованию и описанию конституционного права Европейского союза.

Учебник должен учитывать тот факт, кто его адресаты. Являются ли ими граждане государств ЕС или граждане других государств, а если других, то каких? Каким представляется их общий уровень знаний на тему Европейского союза и конституционного права государств-членов Евросоюза? Также не следует забывать о том, выражают ли данные государства, в рационально определенных временных рамках, желание присоединения к Европейскому союзу, могут ли они стать его членами?

Разрабатываемый учебник адресован тем, кто знаком с основными вопросами Европейского союза, равно как конституционным правом государствчленов Европейского союза, относительно этого нет сомнений. Необходимо делать такие выводы, поскольку знаком с русскоязычными публикациями в данной области, сферой поставленных вопросов, их теоретическим обоснованием. Учитывая вышеизложенное, можно утверждать, что учебник по конституционному праву Европейского союза, чтобы он имел вес для читателя, некое познавательное значение, должен базироваться на приобретенных на занятиях знаниях, которыми уже обладают студенты.

Естественно, в аспекте упорядочения, методологии - должен целостно описывать и разъяснять предмет конституционного права Европейского союза, но при этом представлять собой углубленный анализ, обращающийся к знаниям, уже имеющимся у студентов.

Находящийся в разработке учебник адресован читателям, находящимся за пределами Европейского союза, гражданам государств, которые в предусмотренных временных рамках не станут членами Евросоюза, следовательно - в значительной степени их не будет обязывать право Европейского союза; «в значительной степени» потому, что это учебник по своей сути академический, т.е. адресован элите - людям, которые в связи с осуществляемой профессиональной деятельностью чаще, чем многие другие, имеют дело с Европейским союзом. Как данное обстоятельство влияет на подбор тем в курсе? Способ их представления? Можно предположить, что оно позволяет ограничить анализ вопросов, касающийся отдельно взятых конкретных государств европейской политики, и обратиться именно к конституционному праву, его 
принципам и ценностям, которые, как правило, не подвержены радикальным, частым изменениям. К примеру, довольно сложно предполагать, что органы Европейского союза откажутся от принципа главенства и первоочередности права Европейского союза по отношению к праву конкретных государств, характера директивы Евросоюза или принципа лояльного сотрудничества. Совсем иначе выглядит ситуация с отдельно взятыми вопросами материального права. Например, в чем заключается принцип свободного прохождения услуг или товаров, гармонизация налогового законодательства? Можно ли говорить об их стабильном характере?

В вопросах данного типа можно усматривать риск более частых изменений положений материального права, что представляет собой обстоятельство, влияющее на метод прочтения данной проблематики в учебнике.

В конституционном праве происходят, как минимум, две своего рода революции. Одна из них связана с европеизацией права государств-членов Европейского союза ${ }^{2}$. Происходящей в рамках Европейского союза интернационализации права сопутствует второй процесс, параллельно существующий - глобализация конституционного права 3 . Они способствуют, хоть и в различной степени, стандартизации правовых регулирований, их уподоблению друг к другу, как в формальном аспекте, так и материальном. В то же время, некоторые тенденции интернационализации и глобализации могут быть катализатором распада. Так происходит в том случае, если они не согласуются с государственными условиями, правовой и политической культурой данного народа.

В результате такого процесса, происходящего более или менее осознанно, чуждые конституционные решения либо копируются, либо отклоняются, если только будут признаны непригодными, непроверенными, не отвечающими местным условиям и обычаям, касающимся государственного устройства. Принятие либо отклонение чужих образцов, чуждых концепций государственного устройства, равно как решений более детальных, является, следовательно, постоянным явлением, существующим непрерывно. Даже однозначное отклонение каких-либо концепций или конституционных определений является элементом сравнения и столкновения друг с другом различных моделей государственного устройства и конкретных детальных решений, применяемых в отдельно взятых государствах.

2 См. J. Jaskiernia, Polska nauka prawa konstytucyjnego na przełomie wieków - jakie kryteria i przesłanki ocen?, [в:] M. Zubik (ред.), Dwadzieścia lat transformacji ustrojowej w Polsce, Warszawa 2010, c. 65.

3 J. Szymanek, Tradycje konstytucyjne. Szkice o roli ustawy zasadniczej w spoleczeństwie demokratycznym, Warszawa 2006, c. 35-49. 
Поэтому компаративистика является одним из главных методов создания права, не смотря на результат и то, является ли данная норма, а в ее рамках институт, принцип, ценность или процедура, точкой отсчета для создания права. В связи с этим, несмотря на то, что постсоветские государства (за исключением Литвы, Латвии и Эстонии) не охвачены действием конституционного права Европейского союза, вследствие процессов принятия права подлежат его влиянию.

Однако, следует заметить, что процесс столкновения собственных идей государственного устройства с чуждыми идеями и концепциями, в настоящее время значительно ускорен и происходит в наиболее значимом масштабе. Этому способствует так характерные для сегодняшнего дня явления глобализации и интернационализации, которые не минуют, поскольку даже не могут миновать, конституционное право.

Вследствие происходящей глобализации, понимаемой как проявление унификации основ общественной, экономической, правовой жизни, происходящей в результате возрастающих связей между отдельно взятыми аспектами человеческой жизни, унифицируется и само конституционное право. Во все большей степени оно становится похожим во всех государствах ЕС, а вследствие глобализации - также в рамках данного цивилизационного региона, например, система ценностей Совета Европы.

Уиливающийся процесс укрепления зависимости между государствами и международными организациями вызывает не только уподобление правовых решений, принимаемых в различных государствах, но и охватывает также процесс создания актов международного уровня. В результате глобализации и интернационализации процесс стандартизации государственного устройства не проходит только на внутреннем, государственном уровне, напротив - он ярко представлен в международной плоскости. Он охватывает создание правовых, политических актов сверхнационального уровня. Примером такой глобализации является создание европейской конституции, следовательно, акта, регулирующего институциональный характер ЕС. В то же время, создание такой транснациональной конституции, являющейся символом унификации права, осуществляется с учетом «частичных» конституционных традиций государств Европейского союза. Ведь само понятие «конституция» возникло на почве национального права и касается ключевого нормативного акта данного государства.

Конституции государств-членов Европейского союза и содержащиеся в них правовые решения, правовые понятия являются исходной точкой для создания конституции Европейского союза. Система государственных органов обычно рассматривается сквозь призму разделения власти - законодательная, исполнительная и судебная ее ветви, контролирующие, регули- 
рующие органы. Аналогично ситуация выглядит и с системой органов ЕС. Также с ними мы стараемся соотнести данные понятия. Неслучайно один из органов Европейского союза был назван «Европейским парламентом», а ведь относительно наделенных компетенций он имеет не слишком много общего с национальными парламентами, основные функции которых: законодательная и контролирующая.

В то время, как Европейский парламент не является ни главным создателем нормативных актов Европейского союза, равно как не осуществляет контроля над Европейской комиссией. Он не избирает ее и не может отозвать ее членов. Но именно учитывая государственные конституционные традиции, было принято название «Европейский парламент», по аналогии к национальному парламенту. В свете вышеописанного, можно ли говорить, что тем, чем в системе национальных органов власти является национальный парламент, тем в системе органов Европейского союза - Европейский парламент? Также на такие вопросы должен быть найден ответ в рамках курса конституционного права Европейского союза.

В связи с далеко идущей институционализацией процессов европейской интеграции, чего особым случаем является сам Европейский союз, важным предметом исследований становится конституционное право Европейского союза. Оно создает рамки и инструменты функционирования европейского содружества.

Говоря о конституционном праве Европейского союза, подразумеваем как формальное право Европейского союза, так и материальное, касающееся таких проблем, как правовой и конституционный статус институтов Евросоюза, европейский рынок, процессы принятия решений в Евросоюзе, взаимоотношения между государствами-членами Европейского союза, равно как ими и Европейским союзом, расширение Европейского союза и гражданство Евросоюза.

В рамках процесса европейской интеграции и укрепления отношений, объединяющих интегрирующиеся государства, была построена система права Евросоюза. Она воспринимается как автономная. Это система, выделенная как в отношении государственного, так и международного публичного права. Именно поэтому мы говорим о своеобразной триаде: международное право - европейское право - национальное право.

Источники европейского права могут быть классифицированы с учетом различных критериев. Ключевым является разделение на право первичное (идущее от государств) и вторичное (идущее от институтов Европейского союза). Данное разделение определяет иерархию норм права Евросоюза. Можно выделить писаное и неписаное право, имеющее обязательный и необязательный характер. 
Какие группы вопросов необходимо поддать анализу в учебнике?

Сложная система права Евросоюза, имеющего свои корни в международном праве - однако, обладающего своими характерными чертами - внутренне разнообразная и применяемая в различных плоскостях интеграции, вызывает по природе вещей интерпретационные проблемы. Научному анализу подвержены различные правовые проблемы, от более широких до детальных. К важным проблемам с точки зрения конституционного права Европейского союза мы отнесли бы, прежде всего следующие вопросы:

1. Правовой статус самого Европейского союза - как он определяется в Лиссабонском договоре и других актах Евросоюза, учитывая соотнесение вопросов Европейского союза и международных организаций, Европейского союза как конфедерации или федерации - сходство и различия.

Существенной конституционной проблемой является правомочность политической системы Европейского союза, то есть его источники легитимности. Наиболее популярной моделью легитимности Европейского союза является демократическая легитимность. Принятие варианта демократической легитимности следует из концепции развития Европейского союза в направлении целостной системы, основанной на формировании государственной идентичности на уровне Европейского союза.

Существенной проблемой является вопрос границ конституционной системы Европейского союза. Это принципиальный вопрос о сфере, рамках и уровне интегрирования политики в Европейском союзе. Ведь система не имеет естественных, изначально обозначенных границ, а путем самоопределения может произвольно их создавать. Кроме того, если мы признаем, что применяем относительно нее исключительно критерий эффективности и внутренней целостности, то в принципе не найдем теоретического повода в отказе принятия институтами Евросоюза следующих уровней ответственности. Вопрос, однако, звучит следующим образом: можно ли создавать самоотносимую политическую систему без политического сообщества, а скорее - каким образом обеспечить коммуникацию между политической системой Евросоюза и системами государств-членов ЕС, чтобы путем обратной связи гарантировать ее ограничение?

2. Структурные аспекты Европейского союза, в частности правовые проблемы отношений в рамках горизонтального уровня Евросоюза, охватывающего зависимости между институтами Европейского союза и вертикального уровня, охватывающего многоуровневую систему управления в Европейском союзе: ступень Европейского союза, национальную, региональную и местную.

Важными представляются следствия понимания власти в конкретных условиях политической системы Европейского союза. Власть в данной системе не 
настолько сосредоточена в центре принятия решений и осуществляется им, сколько генерируется путем отношений между субъектами системы. Сутью понимаемой таким образом власти является уход от восприятия ее характера как игры с нулевой суммой. Следовательно, сосредоточение власти в одном центре не предполагает автоматическое ее дополнение в другом и не исключает возможность появления новой системы власти. Скорее даже говорят о сетевом управлении, т.е. решения являются не столько выражением воли какого-либо органа, сколько, зачастую, результатом сплетения различных условий.

3. Правовые обусловленности и последствия применения принципов права Евросоюза, в частности, такие как верховенство права Европейского союза над национальной системой права, непосредственная результативность права Евросоюза, эффективность права Евросоюза, защита правовых ожиданий, надежность права, невозможность обратного действия права, а также принципы, связанные с созданием вторичного права, в том числе принцип возложенных компетенций, принцип вспомогательности и пропорциональности.

Государство остается ключевым, но не единственным объектом международного права. В XXI в. потенциал государства как защитника прав и свобод своих граждан перед глобальными вызовами был расширен новыми факторами. Здесь учитывается проблема безопасности относительно мирового терроризма, финансовые кризисы значительной части государств Европейского союза.

С учетом интернационализации права, связанной с развитием сверхнационального права, государства подчиняются общим нормам, имеющим в широком понимании конституционный характер. Нормы данного типа влияют на внутреннее право и практику. Данное влияние осуществляется различными способами. Они имеют приоритет относительно действия закона. Государственные суды учитывают право Евросоюза при интерпретации и применении положений национального права.

Существуют различные уровни принятия решений. Каждый из них утверждает свой приоритет. Очевидно, наиболее известная иллюстрация данного явления, связана с Германией. Германский Конституционный суд выразил свою компетенцию относительно проверки соответствия права ЕС германской конституции. За ним аналогичную правовую точку зрения выразил польский Конституционный трибунал. В то же времяавстрийский Конституционный суд так активно не проявляет мотив приоритета австрийской конституции относительно положений европейского права. Он разделяет позицию Суда Европейского союза, касающуюся приоритетности в применении положений европейского права относительно национального права, включая национальную конституцию. 
Первоочередность права Европейского союза признана в Эстонии. В свою очередь, французский Конституционный совет в своей практике все чаще признает приоритет права Европейского союза, в то же время, подчеркивая значение принципа главенствующей роли французского парламента. Факт отличного восприятия отношений, существующих между правом Евросоюза и законодательством определенного государства-члена Европейского союза, является важным обстоятельством для изложения конституционного права Европейского союза. Он свидетельствует о том, что существуют конфликтные плоскости между тем, что есть государственное и тем, что относится к Европейскому союзу в целом, что процесс гармонизации права не может проходить бесконфликтно. Напротив, он может вызывать значительное политическое напряжение.

Принципы государственного устройства, как и в случае государства, в Европейском союзе являются основным пунктом, поднимаемым конституционалистами. Насколько в государственных исследованиях они, как правило, укоренены в конституции и обуславливают весь правовой порядок, настолько в праве Евросоюза не существует полной прозрачности, какие правовые материи являются конституционными - те ли, которые содержаться в договорах Евросоюза, или также те, которые следуют из неписаного права ${ }^{4}$. В части исследований учитываются также некоторые принципы национального права, такие как принцип правового государства и принцип демократичности политической системы Европейского союза.

Разногласия касаются, в частности, институтов, реализующих принцип демократичности политической системы Европейского союза. Многие исследования касаются принципа демократизма, его функционирования на европейском уровне, в частности, применения в конкретных случаях принятия решений.

Вторая группа - это принципы, специфические для государственного устройства Европейского союза, формирования, выходящего за рамки правового статуса международной организации. Среди поднимаемых проблем можно назвать следующие: вопрос сверхнациональности, субсидиарности, результативности и эффективности; плюралистический, неиерархический, диалоговый, постнациональный порядок.

4. Правовая регламентация политики Евросоюза, секторов, внутренней и внешней, находящих укоренение в международных и сверхнациональных механизмах (относящихся к содружеству), формирование разного рода политики и управление ею.

4 См. K. A. Wojtaszczyk, Studia europejskie z perspektywy nauk prawnych, [в:] J. Czaputowicz (ред.), Studia europejskie. Wyzwania interdyscyplinarności, Warszawa 2014, c. 100. 
В данном блоке исследований необходимо обратиться к проблематике хозяйственного права. Лежащие на поверхности исследовательские проблемы касаются принципов конкуренции, асимметрии в создании и регулировании рынка, проблемы равновесия между экономическим развитием и уровнем социальных выплат.

5. Процесс принятия решений в Европейском Союзе - правовое регулирование процедур принятия решений, его изменения после Лиссабонского договора.

6. Построение общественной плоскости европейской интеграции, охватывающей не только институты гражданства Европейского союза, но также развитие на уровне Евросоюза форм демократического участия.

В общественной плоскости государственного устройства Европейского союза важными являются решения, связанные с правовым статусом гражданина Европейского союза, такие как реконструкция правового порядка с перспективы гражданина, или правовое и конституционное значение гражданства Евросоюза.

Обращение внимания на политическое участие - это вместе с тем и обращение внимание на качество реализуемого представительского мандата в Европейском парламенте. Следует, к примеру, обратить внимание на зависимость между второстепенным влиянием Европейского парламента (по сравнению с Советом Европы или Европейской комиссией) на процесс принятия решений в Европейском союзе, и фактом относительно низкой явки на выборы в Европейский парламент в большинстве государствчленов Европейского союза. В каждом из государств Европейского союза она ниже, чем на выборах в национальный парламент. Отсюда также важным является обращение к демократичности процесса принятия решений в Евросоюзе, насколько в нем участвует европейский народ, а насколько он обусловлен бюрократическим фактором и группами интересов. Определяя государственное устройство Европейского союза, необходимо упомянуть об участии в выборах в Европейский парламент как фактора его легитимности, специфике политических партий как акторов парламентской игры, политическом лидерстве.

7. Прогрессирующая в процессе европейской интеграции европеизация государственного права. Представление ее правовых и политических последствий и возникающих на данном фоне дилемм.

8. Конституционное право Европейского союза и вызовы глобализации государственного устройства.

Исследовательским мотивом, получающим все большее значение, является вопрос Европейского Союза как актора в глобализирующемся мире. К избранным исследовательским проблемам относятся следующие: отно- 
шение права Евросоюза к праву ВТО (Всемирная торговая организация), европейская интеграция и GATT (Генеральное соглашение по тарифам и торговле), СЕТА (коммерческое соглашение между ЕС и Канадой о зоне свободной торговли), ТТІР (коммерческое соглашение между ЕС и Соединенными Штатами - Трансатлантическое торговое и инвестиционное партнерство). Дебаты распространяются и на другие вопросы хозяйственного права и права конкуренции.

Вышеуказанные проблемы мы склонны трактовать, как исходную точку для определения предмета конституционного права Европейского союза. Как видно, они совпадают с планом учебника, который уже разработан.

\section{Право и политика}

Право и политика являются еще одним вопросом, оказывающим влияние на способ представления проблематики сферы конституционного права Европейского союза. Право и политика не отделены друг от друга. Они тесно связаны, переплетаются между собой. Политический процесс определяет результаты правового и, наоборот, с помощью правовых регулирований реализуются политические цели.

Сложно было бы провести какую-либо четкую демаркационную линию между плоскостью конституционного права и политологической плоскостью. Вместе с тем, основополагающие исследования связаны с наблюдением о том, что предметом анализа изучения конституционного права является нормативный аспект институтов государственного устройства Европейского союза (на основании анализа Лиссабонского договора и других правовых норм). В свою очередь, предметом политологического анализа является функционирование институтов государственного устройства Европейского союза.

Демаркационная линия между конституционным правом и политическими науками обозначена нечетко. Она очевидна для исследователей конституционного права Европейского союза, поскольку они не могут сужать свою деятельность до анализа положений первичного права Европейского союза и других нормативных актов Евросоюза, но обращаются - хоть и в разных аспектах - к практике государственного устройства. Ведь нередко, только опираясь на нее, возможной становится формулировка выводов относительно правовых регулирований, их рациональности или нефункциональности. В свою очередь, политологический анализ институтов Европейского союза не может абстрагироваться от правового аспекта. Ведь без него анализ был бы попросту непонятен. Исследователи конституционного права ста- 
раются анализировать политическую практику, поскольку она лучше всего показывает суть политической системы Европейского союза.

Учебник по конституционному праву Европейского союза должен совмещать: упорядоченность и правовую точность, характерную для конституционного права;политологический подход, требующий отражения политической реальности такой, какая она есть, не смотря на то, перекликается ли это с конституционными конструкциями, или же не соответствует им. Читателю необходимо знать, как должно быть (из перспективы сути правовых норм) и как есть (с точки зрения реальных политических явлений).

Невозможно абстрагироваться от фактических механизмов функционирования Европейского союза в категориях политической игры правительств и групп лобби. Считается, например, что в Брюсселе действует примерно 30 тысяч разного рода лоббистов, из которых более 3 тысяч имеет пропуск в Европейский парламент. Очевидно, они имеют существенное значение в процессе принятия решений в Евросоюзе. Таким образом, необходимо определение фактического значения конкретных механизмов, процедур в рамках процесса принятия решений в Евросоюзе.

Существенная исследовательская проблема, объединяющая правовой и политологический подходы, связана с определением аксиологической системы конституционного права Европейского союза. Речь идет о комплексе ценностей, с которыми идентифицируется Европейский союз. С одной стороны - это ценности, записанные в ключевых программных актах, в том числе - Лиссабонском договоре, Хартии Европейского союза по правам человека, ценностях, декларированных высокопоставленными чиновниками Евросоюза. С другой стороны, невозможно обходить практику стороной. Нельзя не заметить способ реализации данных ценностей в реальности Евросоюза.

Учебник по конституционному праву Европейского союза должен поставить вопрос, насколько отдельные практики Евросоюза являются формой выполнения данных ценностей, а насколько - это выражение партикуляризма государств-членов ЕС, интересов бюрократии Евросоюза, или эффектом влияния различных групп лобби? Насколько практика государственного устройства утверждает, а насколько дезавуирует отдельно взятые ценности, институты или процедуры конституционного права Европейского союза?

Достойна проверки гипотеза, насколько для русскоязычного читателя интересен был бы анализ конституционного права Европейского союза в контексте устройств постсоветских государств, и как минимум формального государственного устройства, поскольку практика в данной сфере ушла другой дорогой - к Евразийскому Союзу.

В данном аспекте проблематика, методология изложения конституционного права Европейского союза могла бы быть полезна для построения 
методологии конституционного права Евразийского Союза, либо иначе. Она могла бы быть теоретическим подтверждением того, что относительно конструкции государственного устройства, Евразийский Союз в малой степени напоминает Европейский союз и не имеет рациональных предпосылок того, что это может измениться. Но, подчеркиваю, это только гипотеза, требующая рассмотрения, дальнейшего анализа.

\section{Резюмe}

В настоящей статье автор рассматривает некоторые вопросы, связанные с подготовкой учебника по конституционному праву Европейского союза. На основе анализа автор коснулся темы диапазона проблематики, охваченной им в общем, и отдельных вопросов в частности. Подчеркивает, почему стоит о них говорить, что обосновывает их присутствие в учебнике.

Jacek Zaleśny

\section{The Constitutional Law of the European Union as an ObJect of SCIENTIFIC RESEARCH}

In this article author considers some issues related to the preparation of a textbook on the constitutional law of the European Union. Author touched on the topic of the range of problems covered in general, and individual issues in particular. Stresses, why it is worth talking about them, which justifies their presence in the textbook.

KEY WORDS: constitutional law, the European Union, a textbook, scientific research

\section{Библиография}

J. Jaskiernia, Polska nauka prawa konstytucyjnego na przetomie wieków - jakie kryteria i przesłanki ocen?, [в:] M. Zubik (ред.), Dwadzieścia lat transformacji ustrojowej w Polsce, Warszawa 2010.

J. Szymanek, Tradycje konstytucyjne. Szkice o roli ustawy zasadniczej w spoleczeństwie demokratycznym, Warszawa 2006.

K. A. Wojtaszczyk, Studia europejskie z perspektywy nauk prawnych, [в:] J. Czaputowicz (ред.), Studia europejskie. Wyzwania interdyscyplinarności, Warszawa 2014. 
Аскар Мирсаидов

ORCID: 0000-0002-7546-2467

\section{Международно-правовые аспекты \\ вступления Узбекистана в ВТО \\ в контексте обзора законодательства \\ в области торговли услугами}

КЛЮЧЕВЫЕ СЛОВА:

Узбекистан, ВТО, вступление в ВТО, законодательство Узбекистана

в области услуг, внешнеэкономические связи Узбекистана

\section{Введение}

Сегодня в Республике Узбекистан последовательно осуществляются экономические реформы на основе рыночных принципов, расширения доли частного сектора, укрепления экономической стабильности и повышения привлекательности республики для иностранных инвесторов ${ }^{1}$.

В данном контексте важным направлением является укрепление международных позиций Республики Узбекистан, развитие международной договорно-правовой базы на двусторонней и многосторонней основе, совершенствование национального законодательства с дальнейшей либерализацией режима внешней торговли и последовательной гармонизацией с международными нормами и правилами Всемирной торговой организации (ВТО).

Сегодня Узбекистан присоединился к более, чем 180 важным многосторонним международным конвенциям и соглашениям в сфере торговоэкономических отношений².

1 Н. Сиражиддинов, Либерализация внешнеторговых операций и конкурентоспособность нащиональной экономики, «Экономическое обозрение» 2017, № 11, с. 67-72.

2 Включая такие основополагающие конвенции в сфере внешней торговли как Конвенция ООН о договорах международной купли-продажи товаров (Вена, 1980 г.), Вашингтонская Конвенция о разрешении инвестиционных споров между государствами и лицами иных государств (1965г.), Нью-Йоркская Конвенция 
Особую актуальность для Республики Узбекистан в свете развития договорно-правовой базы на уровне многостороннего сотрудничества приобретает членство в международных организациях. Став членом уже большинства самых авторитетных из них, республика не останавливается на достигнутом.

Вступление в ВТО является одним из приоритетных направлений внешнеэкономической политики Правительства Узбекистана и рассматривается как один из ключевых факторов улучшения международного имиджа и привлекательности страны для инвесторов.

\section{Всемирная торговая организация как приоритет внешнеэкономической политики Республики Узбекистан}

Многосторонняя система регулирования торгово-экономических отношений в рамках ВТО включает в себя три базовых элемента:

1) многосторонние соглашения по торговле товарами, особое место среди которых занимает Генеральное соглашение по тарифам и торговле (ГАТТ);

2) Генеральное соглашение по торговле услугами, призванное регулировать торговлю услугами на принципах недискриминации и режима наибольшего благоприятствования (РНБ);

3) Соглашение по торговым аспектам прав интеллектуальной собственности, в котором определяются основополагающие принципы торговых аспектов прав интеллектуальной собственности ${ }^{3}$.

ВТО в настоящее время является единственной глобальной международной организацией, в рамках которой обсуждаются и разрабатываются все основные вопросы, связанные с международной торговлей. Сфера деятельности ВТО охватывает более $94 \%$ общего объема товарных потоков ${ }^{4}$.

В разработанной во главе с Президентом Республики Узбекистан Ш.М. Мирзиеевым Стратегии действий по пяти приоритетным направлениям развития Республики Узбекистан в 2017-2021 гг. третий раздел посвящен «Приоритетным направлениям развития и либерализации экономики» 5 . Он включает в себя реализацию ряда конкретных мер, направленных на

о признании и приведении в исполнение иностранных арбитражных решений (1958 г.), Венская Конвенция о праве международных договоров (1969 г.) и др.

3 А. П. Портанский, Многосторонняя торговая система и перспективы ее реформирования, Москва 2015, с. 31-35.

4 The WTO, https://www.wto.org/english/thewto_e/thewto_e.htm (дата обращения: 20.01.2019).

5 См.: Указ Президента Республики Узбекистан «О Стратегии действий по дальнейшему развитию Республики Узбекистан» от 7 февраля 2017 г., Собрание законодательства Республики Узбекистан 2017 г., № 6, ст. 70, № 20, ст. 354. 
улучшение международного имиджа и привлекательности республики для иностранных инвесторов.

Наряду с этим, в государственной программе Республики Узбекистан на 2018 год - «Год активного предпринимательства, инновационных идей и технологий» ${ }^{6}$, предусматривается реализация ряда мер, направленных на ускорение работ по вступлению в ВТО. В частности, подготовка предложений по приведению законодательства Узбекистана в соответствие с нормами организации, утверждение нового состава межведомственной комиссии, которая будет заниматься вопросами вступления в ВТО и проведение большого количества изменений и реформ в стране.

Комплекс мер также предполагает проведение оценки последствий членства в данной организации и подготовку предложений по проведению институциональных реформ ${ }^{7}$.

В декабре 1994 г. Узбекистан подал заявление о намерении Узбекистана вступить в ГАТТ/ВТО в качестве полноправного члена. 21 декабря 1995 г. Генеральный совет ВТО на своей очередной сессии, положительно рассмотрев заявку, принял решение о создании Рабочей группы по вступлению Узбекистана в ВТО. В сентябре 1998 г. состоялось официальное представление Меморандума по режиму внешней торговли Узбекистана в Секретариат ВТО и копий выдержек из законов и законодательных актов Узбекистана, касающихся режима внешнеторговой деятельности. К настоящему времени проведены три заседания рабочей группы по вступлению Узбекистана в ВТО, ведутся подготовительные работы по проведению четвертого заседания, а также второго заседания многосторонних переговоров по сельскому хозяйству и двусторонних переговоров со странами-участницами рабочей группы.

С момента представления Меморандума о режиме внешней торговли Республики Узбекистан в Секретариат ВТО в октябре 1998 г. ${ }^{8}$, в стране принят целый ряд новых законодательных актов, способствующих дальнейшей либерализации режима внешней торговли, его адаптации к международным нормам и правилам ВТО. Последовательно осуществляются реформы экономической системы, направленные на развитие рыночных принципов, расширение доли частного сектора, укрепление экономической стабильности и повышение привлекательности нашего рынка для иностранных инвесторов.

6 Там же.

7 Стратегия действий по пяти приоритетным направлениям развития Республики Узбекистан в 2017-2021 годаx, http://2018.strategy.uz/ (дата обращения: 20.01.2019).

8 Документ представленный Узбекистаном в Секретариат ВТО № WT/ACC/UZB/2 от 21.10.1998 г. 


\section{Правовая политика Республики Узбекистан по либерализации внешнеторгового режима}

Становление национальной законодательной базы Республики Узбекистан в сфере регулирования внешнеэкономической деятельности (далее - ВЭД) началось в 1992 году. Как было отмечено Первым Президентом Республики Узбекистан И. А. Каримовым стержневой основой в данной области был провозглашен постепенный отказ от приоритета административных методов регулирования над экономическими методами, но при сохранении некоторого контроля государства за деятельностью хозяйствующих субъектов Узбекистана, осуществляющих экспортно-импортные операции 9 . Данная система, по мнению автора статьи, должна была, с одной стороны, отвечать требованиям адаптации республики к условиям рыночной экономики, с другой - интеграции в мировое экономическое хозяйство на качественно новом уровне с учетом развития экономически обоснованных торговых отношений с зарубежными странами.

За прошедший период были приняты Законы Республики Узбекистан «О внешнеэкономической деятельности», «О таможенном тарифе», Налоговый и Таможенный кодексы Республики Узбекистан и другие нормативные акты ${ }^{10}$, которые позволили сформировать основные рамочные условия для осуществления внешнеэкономических связей, заключения и исполнения международных договоров в области внешнеэкономической деятельности, защиту экономических интересов республики, юридических лиц и граждан Узбекистана за его пределами, установить правовые гарантии для деятельности иностранных инвесторов.

Вопросы правового регулирования ВЭД решались не только вышеуказанными законами, но и Указами, Постановлениями Президента Республики Узбекистан, Постановлениями Кабинета Министров Республики Узбекистан, нормативными актами ведомств, регулирующих экспортно-импортные операции в Узбекистане ${ }^{11}$.

9 И. А. Каримов, Важнейшие задачи углубления демократических реформ на современном этапе, Ташкент 1996, с. 85.

10 Указ Президента Республики Узбекистан от 24 июля 1992 г. № УП-445 «О мерах по стимулированию внешнеэкономической деятельности, привлечению и защите иностранных инвестиций в Республике Узбекистан», Постановления Кабинета Министров Республики Узбекистан от 21 октября 1992 г. № 485 «О мерах по стимулированию внешнеэкономической деятельности, привлечению и защите иностранных инвестиций в Республике Узбекистан», «О мерах по регулированию внешнеторговых операций» от 25 марта 1994 г. № 163, «О мерах по дальнейшей либерализации и совершенствованию внешнеэкономической деятельности» от 25 июля 1995 г. № 287.

11 Там же. 
Наряду с этим, формирование прочной правовой базы в стране создало благоприятный инвестиционный климат, стимулирующий расширение внешнеторговых связей, существенно упростило механизм создания предприятий с иностранными инвестициями, регистрации участников ВЭД.

Как было неоднократно отмечено Первым Президентом Республики Узбекистан И. А. Каримовым, Правительство Республики Узбекистан придерживается активной политики законодательного поощрения прямых иностранных инвестиций, особенно в приоритетные сектора экономики ${ }^{12}$.

Внешнеторговый режим Республики Узбекистан характеризуется своей открытостью. Экспортные таможенные пошлины на все виды товаров (работ, услуг) отменены. Экспорт товаров (работ, услуг) за свободно конвертируемую валюту, включая поставки в страны СНГ, облагаются по нулевой ставке НДС. Кроме того, поставка товаров на экспорт за свободно конвертируемую валюту освобождается от уплаты акцизного налога.

Либерализация ВЭД в среднесрочной перспективе является одним из ключевых направлений экономической политики Узбекистана ${ }^{13}$, способствующих преодолению кризисных явлений, улучшению положения в системе международного разделения труда, расширению рынков сбыта отечественной продукции. В сложный для Узбекистана период проведения экономических реформ ВЭД может обеспечить поддержание национальной экономики и стабилизацию промышленного экспорта за счет поставок продукции на внешние рынки. Очевидно, что без динамичного изменения объемов, структуры и качественных характеристик экспорта дальнейшие усилия по преодолению экономических проблем могут быть неоправданны.

За годы независимости в Республике Узбекистан создан благоприятный инвестиционный климат, широкая система правовых гарантий и льгот для иностранных инвесторов, который характеризуется, в первую очередь, сохраняющейся в республике политической и экономической стабильностью. Кроме того, разработана целостная система мер по стимулированию деятельности предприятий с иностранными инвестициями, включающая в себя:

- общие меры, в том числе льготы для проектов, реализуемых в соответствии с подписанными инвестиционными договорами;

- стимулирование участия иностранных инвесторов в процессе приватизации;

12 И. А. Каримов, Узбекистан: наџиональная независимость, экономика, политика, идеология, Ташкент 1993, с. 137.

13 Из доклада Министра внешних экономических связей, инвестиций и торговли Республики Узбекистан Э. М. Ганиева на семинаре - совещании Межведомственной комиссии по работе с ВТО (февраль 1999 г.). 
- стимулирования технического перевооружения и производства товаров народного потребления.

Законы Республики Узбекистан - «Об иностранных инвестициях» от 30 апреля 1998 г. № 609-I, «О гарантиях и мерах защиты прав иностранных инвесторов» от 30 апреля 1998 г. № 611-I, «Об инвестиционной деятельности» от 24 декабря 1998 г. № 719-I, «О гарантиях свободы предпринимательской деятельности» от 25 мая 2000 г. № 69-II, «О соглашениях о разделе продукции» от 7 декабря 2001 г. № 312-II ${ }^{14}$ - на сегодняшний день являются теми основными законодательными актами, которыми гарантируется защита иностранных инвестиций, устанавливаются обширные гарантии по защите прав и законных интересов иностранного инвестора 15.

Как отмечается в информации Министерства внешних экономических связей, инвестиций и торговли, уровень ставок таможенных пошлин по товарным группам и субпозициям произведен на основе международного, распространенного опыта, по принципу - чем больше добавленная стоимость товара, тем выше ставка пошлины ${ }^{16}$.

В целях недопущения искусственного занижения таможенной стоимости декларируемых товаров расширена номенклатура товаров, на которые применяются комбинированные ставки пошлин.

Кроме того, в целях дальнейшего обеспечения устойчивого развития отечественных предприятий, производящих готовую текстильную продукцию, благоприятных условий для повышения ее конкурентоспособности на внутреннем и внешнем рынках, с 1 октября 2017 г. установлены новые таможенные пошлины на готовую текстильную продукцию ${ }^{17}$.

Физические лица, в соответствии с постановлением Кабинета Министров Республики Узбекистан от 27 сентября 2002 г. № 335 «О внесении изменений в отдельные решения Правительства Республики Узбекистан по вопросам упорядочения ввоза товаров физическими лицами на территории республики» ${ }^{18}$, уплачивают единый таможенный платеж, взимаемый от таможенной стоимости товара без применения норм беспошлинного ввоза по всем категориям товаров, независимо от кода ТН ВЭД и страны происхождения товара в размере:

14 Собрание законодательства Республики Узбекистан 2017, № 6, ст. 70, № 20, ст. 354.

$15 \mathrm{http} / / / \mathrm{v} 3 . \mathrm{mfer} . u \mathrm{z} / /$ inostrannie_investiii/inostrannie_investiii/investiionnaya_politika_ respubliki_uzbekistan/ (дата об̄ращения: 20.01.2019).

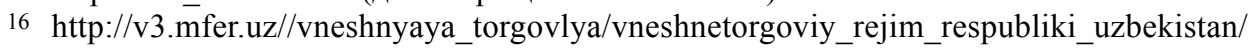
(дата обращения: 20.01.2019).

17 Постановление Президента Республики Узбекистан от 29 сентября 2017 г., № ПП-3303 «О мерах по дальнейшему упорядочению внешнеэкономической деятельности Республики Узбекистан».

18 Собрание законодательства Республики Узбекистан 2002, № 17-18, ст. 142. 
- 40 процентов по продовольственным товарам (за исключением муки);

- 70 процентов по непродовольственным товарам ${ }^{19}$.

Открытый характер таможенного тарифа объясняется наличием целого ряда льгот по уплате таможенных пошлин. В частности, не облагаются импортными таможенными пошлинами:

- товары, происходящие и ввозимые из государств, с которыми установлен режим свободной торговли (по итогам периода ? г. удельный вес импорта из стран СНГ 36,8\% от общего объема импорта республики);

- товары, поставляемые по межправительственным и кредитным соглашениям, заключенным от имени Правительства Республики Узбекистан или под его гарантии;

- товары для реализации инвестиционных проектов, финансируемых за счет иностранных кредитов под гарантию правительства;

- имущество, ввозимое иностранными инвесторами для собственных производственных нужд;

- инвестиции в качестве вклада в уставный капитал предприятий с иностранными инвестициями;

- технологическое оборудование;

- оборудование для создания сетей передач компьютерных данных, компьютерная техника, комплектующие, программные средства;

- оборудование для предприятий малого бизнеса;

- древесина и лесоматериалы;

- материалы и компоненты, не производимые в республике и используемые при производстве локализуемой продукции предприятиями, на которых реализуются проекты в рамках Программы локализации в соответствии с Постановлением Президента Республики Узбекистан № ПП-1048 от 27 января 2009 г. «О программе локализации производства готовой продукции, комплектующих изделий и материалов на основе промышленной кооперации на 2009 год» ${ }^{20}$.

Кроме того, импорт целого ряда товаров не облагается также налогом на добавленную стоимость. К товарам, при импорте которых не применяется НДС, относятся:

- технологическое оборудование, ввозимое:

- для оснащения включенных в инвестиционную программу приоритетных объектов;

- для реализации инвестиционных проектов, финансируемых за счет иностранных кредитов под гарантии правительства;

19 Там же.

20 Собрание законодательства Республики Узбекистан 2009 г., № 5, ст. 35, № 49, ст. 522, № 52 , ст. 561 . 
- для вновь строящихся и реконструируемых предприятий, специализирующихся на производстве товаров народного потребления;

- иностранными инвесторами в качестве их вклада в уставной капитал предприятий с иностранными инвестициями ${ }^{21}$;

- оборудование, материалы (работы и услуги), ввозимые юридическими лицами, включая нерезидентов Узбекистана, за счет займов и грантов, предоставленных международными и зарубежными правительственными организациями по соглашениям, заключенным Республикой Узбекистан; - оборудование для создания сетей передач компьютерных данных, компьютерная техника и комплектующие к ним, а также программные средства;

- лекарственные средства и изделия медицинского назначения.

Средневзвешенный тариф, рассчитанный в соответствии с определениями ВТО по данным 2007 г. составляет 2,5\%, что по классификации ВТО позволяет отнести тарифный режим Узбекистана к категории «открытого» (средневзвешенный тариф составляет менее 10\%).

Отсутствует таможенная пошлина на сырье или она является минимальной, что является стимулом для отечественных производителей производить готовые изделия. Нулевая ставка также предусмотрена для некоторых товарных позиций, указанных в вышеуказанном Постановлении.

Импортные таможенные пошлины не взимаются при импорте товаров, происходящих с таможенной территории стран, подписавших Соглашение о создании зоны свободной торговли 22 .

Наряду с этим, Республика Узбекистан предоставляет режим наибольшего благоприятствования 45 странам мира ${ }^{23}$, в соответствии с заключенными двухсторонними договорами о взаимном сотрудничестве. В Узбекистане не применяются импортные квоты ${ }^{24}$. Однако, согласно Монреальского

21 http://v3.mfer.uz//zakonodatelstvo_v_sfere_ved/polojenie/polojenie_o_poryadke_prime neniya_nalogovix_i_tamojennix_lgo_dlya_predpriyatiy_speializiruyushixsya_na_vipuske neprodovolstvennix_potrebitelskix_tovarov_ot_10032009g/ (дата обращения: 20.01.2019).

22 Участниками вышеуказанного соглашения являются Беларусь, Грузия, Казахстан, Кыргызстан, Молдова, Россия, Туркменистан, Украина, Таджикистан, Армения, Азербайджан.

23 Режим наибольшего благоприятствования предоставлен таким странам как: Австрия, Бангладеш, Бельгия, Болгария, Великобритания, Венгрия, Вьетнам, Германия, Греция, Дания, Египет, Израиль, Индия, Ирландия, Испания, Италия, Иордания, Кипр, Корея, Китай, Латвия, Литва, Мальта, Люксембург, Нидерланды, Португалия, Пакистан, Польша, Словения, Румыния, Словакия, США, Турция, Финляндия, Франция, Чехия, Швейцария, Швеция, Эстония, Япония, Саудовская Аравия, Малайзия, Иран, Сингапур.

$24 \mathrm{http} / / / \mathrm{v} 3 . \mathrm{mfer} . u z / / \mathrm{vneshnyaya}$ _torgovlya/vneshnetorgoviy_rejim_respubliki_uzbekistan/ (дата обращения: 20.01.2019). 
протокола по веществам, разрушающим озоновый слой, от 1987 г. в республике утверждены квоты на ввоз в Республику Узбекистан озоноразрушающих веществ на период 2005-2030 годов. Квоты утверждены в соответствии с Постановлением Кабинета Министров Республики Узбекистан от 11 ноября 2005 г. № 247 «О совершенствовании регулирования ввоза в Республику Узбекистан и вывоза из Республики Узбекистан озоноразрушающих веществ и продукции, их содержащей».

В тоже время, согласно ст. 21 Закона Республики Узбекистан «О внешнеэкономической деятельности» в отношении экспорта и импорта отдельных видов товаров Кабинет Министров Республики Узбекистан может установить количественные ограничения (квоты).

Распределение квот осуществляется, как правило, на конкурсной или аукционной основе.

В соответствии с Указом Президента Республики Узбекистан от 26 сентября 2003 г. № УП-3321 «О мерах по дальнейшей либерализации внешнеторговой деятельности» в Республике Узбекистан с 1 октября 2003 г. отменена предварительная регистрация импортных контрактов в Министерстве внешних экономических связей, инвестиций и торговли и установлено, что экспертизе в МВЭСИТ подлежат импортные контракты:

- финансируемые за счет государственного бюджета;

- финансируемые за счет кредитов (займов), привлеченных Правительством Республики Узбекистан или под его гарантию;

- заключаемые хозяйствующими субъектами, в уставном капитале которых доля государства составляет 50 и более процентов, и не обеспеченные собственными валютными ресурсами.

При экспорте регистрации в Министерстве внешних экономических связей, инвестиций и торговли Республики Узбекистан подлежат только контракты на экспорт специфических товаров 25 .

25 В этот перечень входит: вооружение и военная техника, специальные комплектующие изделия для их производства; драгоценные металлы, сплавы, изделия из них, руды концентраты, лом и отходы драгоценные природные камни и изделия из них, отходы, порошки и рекуператор драгоценных природных камней, жемчуг и изделия из него, янтарь и изделия из него; уран и другие радиоактивные вещества, изделия из них, отходы радиоактивных веществ; приборы и оборудование с использованием радиоактивных веществ; цветные металлы, прокат цветных металлов, лом и отходы цветных металлов; прокат черных металлов, лом и отходы черных металлов; нефть сырая, газ природный, волокно хлопковое, линт хлопковый. 


\section{Обзор законодательства Узбекистана в области торговли услугами}

Основными целями государственного регулирования сектора услуг в Республике Узбекистан являются устранение недобросовестной конкуренции, обеспечение национальной безопасности, защита жизни, здоровья и экономических интересов потребителей, а также защита окружающей среды. Отдельные виды услуг подлежат лицензированию.

Постановлением Олий Мажлиса Республики Узбекистан от 12 мая 2001 г. № 222-II “О порядке выдачи предприятиям (организациям) специальных разрешений (лицензий) на право занятия отдельными видами деятельности" утвержден перечень видов деятельности, подлежащих лицензированию. Перечень лицензирующих органов, осуществляющих лицензирование отдельных видов деятельности, определен Постановлением Кабинета Министров от 28 июня 2002 г. № 236 “О мерах по реализации Закона Республики Узбекистан «О лицензировании отдельных видов деятельности» ${ }^{26}$. В их число входят: Кабинет Министров, Министерство юстиции, Министерство финансов, Центральный банк, Министерство внутренних дел, Министерство здравоохранения, Министерство образования, Государственный таможенный комитет Республики Узбекистан, Министерство по развитию информационных технологий и коммуникаций и др.

Общие процедурные требования в отношении сертификации услуг соответствуют основным принципам Международной организации стандартизации (МОС). Узбекистан также следует принципам соглашения между странами СНГ в отношении координированной политики по стандартизации, метрологии и сертификации и двусторонним соглашениям, основанным на нем. В связи с этим, Агентство "Узстандарт" признает сертификаты на услуги, выданные странами СНГ.

Основным антимонопольным законодательным актом республики, регулирующим деятельность монополий, является Закон Республики Узбекистан от 27 декабря 1996 г. “О конкуренции и ограничении монополистической деятельности на товарных рынках". Проведение государственной политики по содействию развития конкуренции на товарных рынках, ограничению и пресечению монополистической деятельности и недобросовестной конкуренции хозяйствующих субъектов, государственных органов управления и органов государственной власти на местах осуществляется Государственным комитетом Республики Узбекистан по демонополизации и развитию конкуренции.

26 Собрание законодательства Республики Узбекистан 2002, № 11-12, ст. 97. 
Кроме того, 19 августа 1999 г. принята новая редакция Закона Республики Узбекистан “О естественных монополиях” №815-I27.

В соответствии со ст. 4 Закона государственное регулирование деятельности субъектов естественных монополий устанавливается в сфере добычи нефти, газового конденсата, природного газа и угля, транспортировки нефти, нефтепродуктов и газа по трубопроводам, производства и транспортировки электрической и тепловой энергии, железнодорожных перевозок, услуг общедоступной электрической и почтовой связи, водопроводного и канализационного обслуживания. Государственному регулированию подлежат также услуги портов и аэропортов.

В соответствии со ст. 71 Налогового кодекса Республики Узбекистан отдельные виды услуг (услуги по проведению операций страхования и перестрахования, услуги в сфере народного образования, услуги организаций связи по выплате пенсий и пособий и т.д.) освобождены от уплаты НДС. В соответствии со ст. 31 Налогового кодекса от налога на доходы (прибыль) освобождаются юридические лица-поставщики городских транспортных услуг (исключая такси) по услугам, связанным с перевозкой пассажиров.

Существуют определенные требования, предусматривающие специфические виды юридических лиц, через которых может быть предоставлена услуга. Их несколько: банковские услуги должны быть предоставлены через акционерные общества, организованные в Узбекистане; услуги инвестиционных фондов могут быть предоставлены через акционерные общества открытого типа, организованные в Узбекистане; страховые услуги могут быть предоставлены через юридические лица, созданные в Узбекистане, в том числе с участием или без участия местных юридических лиц.

В целом, Республика Узбекистан обеспечивает для иностранных поставщиков услуг недискриминационный режим с некоторыми исключениями: только узбекская авиакомпания может обеспечивать услуги по внутренним воздушным маршрутам; иностранные авиакомпании, получившие лицензии от узбекской авиакомпании, могут предлагать услуги перевозок по международным маршрутам; на территории республики банки с иностранным участием должны иметь минимальный уставной капитал в сумме 5 млн. долл. США; размер уставного капитала для местного банка без иностранного участия устанавливается Центральным банком Узбекистана в зависимости от каждого отдельного случая; только гражданин Республики Узбекистан может стать адвокатом, и только адвокат может предоставлять юридические услуги в процессе слушания уголовных дел, во всех других случаях предоставления юридических услуг иностранные адвокаты и юри-

27 Ведомости Олий Мажлиса Республики Узбекистан 1999, № 9, ст. 212. 
сты могут получить лицензии на ведение дел на тех же правах, что и граждане Узбекистана; для оказания страховых услуг на территории Узбекистана, иностранные страховщики должны учредить юридическое лицо Республики Узбекистан с участием или без участия местного капитала.

Республика Узбекистан предоставляет одинаковый режим иностранным поставщикам услуг независимо от их гражданства. Также республика предоставляет одинаковый режим компаниям и отдельным лицам, которые желают инвестировать в ее сектор услуг.

\section{Юридические услуги}

Деятельность юристов и юридических контор регулируется Министерством юстиции, которое в соответствии с Постановлением Кабинета Министров от 19 апреля 1994 г. № 215 получило полномочия выдавать лицензии на право оказания юридических услуг. В соответствии с существующими положениями любой гражданин, имеющий диплом специального юридического учебного заведения о высшем юридическом образовании, может обратиться за получением лицензии на предоставление юридических услуг гражданам, предприятиям и организациям. Юридическое лицо, обращающееся за лицензией, должно иметь положение в его учредительных документах о том, что данное лицо уполномочено предоставлять такие услуги.

В соответствии с принятым Олий Мажлисом Республики Узбекистан Законом «О нотариате» от 26 декабря 1996 г. № 343-I28 с 1 марта 1997 г. на территории Узбекистана разрешена деятельность нотариусов и дается право на создание нотариальных контор со стороны Министерства юстиции ${ }^{29}$.

\section{Телекоммуникационные услуги}

На рынке телекоммуникационных услуг: услуги телефонной связи предоставляются в основном акционерными компаниями открытого типа "Махаллий Телеком" (местная связь) и “Халкаро Телеком” (международная связь). В настоящее время ведется установка цифровой междугородной и международной телекоммуникационных сетей с “Алкател СЕЛ АГ”, “Де-Те-Лайн”, “Сименс АГ” (Германия). Осуществлено строительство национального сегмента Трансазиатско-европейской волоконно-оптической линии связи.

Согласно Постановлению Кабинета Министров Республики Узбекистан от 21 августа 2003 г. № 360 “Об утверждении положений о лицензировании

28 Ведомости Олий Мажлиса Республики Узбекистан 1997, № 2, ст. 42.

29 Ст. 8 Закона Республики Узбекистан “О нотариате” от 26 декабря 1996, № 343-I. 
отдельных видов деятельности в сфере транспорта" 30 , фирмы, желающие заниматься предложением телекоммуникационных услуг (например, услуги международной телефонной связи, междугородной телефонной линии, местной телефонной связи, телеграфной, факсимильной и почтовой связи) должны получить лицензию Комиссии Кабинета Министров по лицензированию в сфере транспорта и связи. Лицензированию подлежат проектирование, строительство и эксплуатация следующих видов электрической связи: междугородные телефонные линии связи; международные телефонные линии связи; сети сотовой радиосвязи общего пользования; персональный радиовызов общего пользования сети обработки и передачи данных; распространение теле и радиопередач. Деятельность поставщиков телекоммуникационных услуг регулируется Узбекским агентством почты и телекоммуникаций, которое несет ответственность за обеспечение соблюдения условий лицензирования.

Министерство по развитию информационных технологий и коммуникаций, акционерная компания "Узбекистон почтаси” оказывают предоставление почтовых услуг, а также, на основании соглашений с "Махаллий Телеком" и “Халкаро Телеком”, услуг персональной телеграммной связи и услуг персональной международной телефонной связи для всех желающих. Государственно-акционерная компания "Узбекистон почтаси” предоставляет такие услуги на большинстве из своих узлов по всей республике. Частные компании могут брать линии связи в аренду.

Линии, находящиеся в ведении “Махаллий Телеком" и "Халкаро Телеком”, используются для голосовой связи и передачи данных, включая обмен компьютерными данными и факсимильную связь. Международная связь осуществляется через Ташкентский центр международной электронной связи. Часть ее передается с использованием системы спутниковой связи "Интелсат".

Государственные медицинские учреждения оказывают медицинские и стоматологические услуги населению бесплатно. Обеспечение медицинских услуг закреплено Законом Республики Узбекистан от 29 августа 1996 г. № 265-I “Об охране здоровья граждан”31.

Государство не ограничивает ни формы собственности, ни количество медицинских учреждений. Постановление Кабинета Министров от 5 мая 1992 г. № 240 “О перечне видов деятельности, которыми предприятия (организации) вправе заниматься только на основании специальных разрешений (лицензий)” и приказ Министерства здравоохранения от 16 июля 1992 г. № 343

30 Собрание законодательства Республики Узбекистан 2003, № 15-16, ст. 131.

31 Ведомости Олий Мажлиса Республики Узбекистан 1996, № 9, ст. 128. 
“Об организации лицензионной комиссии при Министерстве здравоохранения” предусматривают организацию частных медицинских учреждений. Такие частные учреждения обязаны пройти лицензирование в Министерстве здравоохранения. В соответствии с Постановлением Кабинета Министров от 19 апреля 1994 г. № 215 поставщики платных медицинских услуг, включая медицинские клиники и поставщиков фармакологических услуг, подлежат лицензированию в Министерстве здравоохранения. Постановление Кабинета Министров Республики Узбекистан от 21 июня 2017 г. № 405 “О мерах по дальнейшему совершенствованию порядка лицензирования медицинской деятельности" 32 предусматривает, что гражданин, который получил необходимое образование и имеет диплом, подтверждающий наличие такого образования, а также обладает по крайней мере пятилетним опытом работы по профессии, может обратиться в Министерство здравоохранения за лицензией на осуществление медицинской деятельности. Лицензиат должен также зарегистрироваться в местных органах государственной власти, на территории которых он планирует заниматься частной практикой.

Любое лицо, в том числе иностранный гражданин, отвечающий необходимым требованиям, имеет право на получение лицензии и занятие частной практикой при условии признания Министерством здравоохранения медицинского учебного заведения, выдавшего ему диплом. Граждане иностранных государств при изъявлении желания заниматься частной врачебной практикой должны предварительно пройти аттестацию в Министерстве здравоохранения Республики Узбекистан на соответствие профессиональным требованиям, установленным в Республике Узбекистан, если иное не предусмотрено международными договорами и соглашениями.

Частным поставщикам медицинских услуг запрещается проводить лечение туберкулеза, психических, венерических, онкологических, а также серьезных воспалительных или инфекционных заболеваний (например, СПИД, проказа). Производство, хранение и реализация наркотиков, психотропных и сильнодействующих препаратов частными фармакологическими учреждениями запрещается.

\section{Образование}

В настоящее время не существует законов и положений в отношении организации частных школ. Все заявления на получение разрешения об организации частной школы рассматриваются индивидуально Министерством народного образования Республики Узбекистан, на которое возложена

32 Собрание законодательства Республики Узбекистан 2017, № 25, ст. 548. 
ответственность по лицензированию учебных заведений. Лицо, желающее открыть частный университет, должно получить лицензию в Министерстве высшего и среднего специального образования, которое рассматривает такие заявления в индивидуальном порядке.

\section{Банковские услуги}

Функции регулирования финансами принадлежат Министерству финансов и Центральному банку Узбекистана (ЦБУ). ЦБУ обладает значительной независимостью в соответствии с Законом Республики Узбекистан “О Центральном банке" принятым 21 декабря 1995 г. Он имеет право выпускать банкноты и монеты, регулирует использование иностранной валюты на территории Узбекистана. ЦБУ выдает наличность, предоставляет услуги по вкладам и переводам государству, утверждает размеры и условия предоставления ссуд Правительству Республики Узбекистан, утверждает экономические нормативы для банков и контролирует их соблюдение, принимает решения о выдаче и отзыве лицензий на занятие банковской деятельностью.

25 апреля 1996 г. Олий Мажлис Республики Узбекистан принял Закон № 216-I “О банках и банковской деятельности” 33, являющийся фундаментальным законодательным актом, регулирующим деятельность коммерческих банков. Данный закон предоставляет полномочия ЦБУ по установлению требований в отношении минимального уставного капитала для коммерческих банков на дифференцированной основе.

Для занятия коммерческой банковской деятельностью и предоставления прочих финансовых услуг заинтересованному юридическому лицу необходимо получить лицензию и пройти регистрацию в ЦБУ. Банкам нет необходимости регистрироваться в других государственных органах.

\section{Транспортные услуги}

Все физические и юридические лица, предлагающие транспортные услуги населению, включая транспортно-экспедиторские компании, и физические или юридические лица, предлагающие ремонтные или технические услуги, связанные с транспортировкой, транспортной отрасли или населению, должны иметь лицензии. Указанное требование предусмотрено постановлением Кабинета Министров Республики Узбекистан от 19 апреля 1994 г. № 215, которое уполномочивает Кабинет Министров выдавать лицензии субъектам, занятым в транспортной отрасли.

33 Ведомости Олий Мажлиса Республики Узбекистан 1996, № 5-6, ст. 54. 
Для получения права на предоставление следующих видов услуг по автомобильным перевозкам, физическому или юридическому лицу необходимо иметь соответствующую лицензию на: перевозку товаров; перевозку пассажиров; транспортно-экспедиционные услуги; предоставление ремонтных или технических услуг, связанных с транспортировкой, транспортной отрасли или населению.

Услуги в области воздушных перевозок регулируются Воздушным Кодексом от 7 мая 1993 г. В соответствии с Воздушным Кодексом, только Национальная авиакомпания "Узбекистон хаво йуллари" может оказывать услуги на внутренних авиалиниях.

В настоящее время семь иностранных авиаперевозчиков уже получили лицензии на международные авиаперевозки в Узбекистане. Акционерное общество "Узбекистон темир йуллари", учреждено в соответствии с Указом Президента Республики Узбекистан от 7 ноября 1994 г.

Постановление Кабинета Министров от 14 ноября 1994 г. № 551 “О вопросах организации деятельности АО "Узбекистон темир йуллари" предоставляет право компании "Узбекистон темир йуллари” принимать решения о методах управления и организации работы системы железнодорожного транспорта. Данная компания оказывает весь комплекс услуг на железнодорожном транспорте и считается естественной монополией ${ }^{34}$.

Постановление Кабинета Министров Республики Узбекистан от 12 мая 1996 г. № 175 предусматривает лицензирование частных компаний и предприятий, занимающихся предоставлением услуг в области железнодорожного транспорта в Комиссии по лицензированию в сфере транспорта и связи.

\section{Страхование}

Фундаментальные изменения, происходящие на рынке услуг по страхованию, характеризуются переходом от системы, где страхование производилось в рамках одной государственной компании, к рынку, предусматривающему наличие как государственных компаний (Национальная компания экспортноимпортного страхования "Узбекинвест", Государственно-акционерная страховая компания "Узагросугурта", Государственно-акционерная страховая компания “Кафолат”), так и более 50 страховых компаний, имеющих смешанную форму собственности, в том числе четыре компании с участием иностранного капитала. Основой для развития системы страхования является Закон Республики Узбекистан от 5 апреля 2002 г. №358-II “О страховой деятельности”35.

34 Ведомости Верховного Совета Республики Узбекистан 1994, № 11-12, ст. 288.

35 Ведомости Олий Мажлиса Республики Узбекистан 2002, № 4-5, ст. 68. 
Страхование может осуществляться в добровольной и обязательной формах. Для занятия страховой деятельностью необходимо зарегистрироваться в муниципальных органах (хокимиятах), Министерстве юстиции, Министерстве финансов. Регистрация производится на недискриминационной основе.

\section{Заключение}

Либерализация внешней торговли в соответствии с требованиями ВТО будет способствовать повышению открытости экономики Узбекистана, созданию конкурентной среды, устранению искажения цен и повышению эффективности распределения и использования ресурсов, более полному использованию преимуществ международного разделения труда и повышению на этой основе благосостояния нации в среднесрочной и долгосрочной перспективе. Важно и то, что членство в ВТО является своего рода гарантом предсказуемости и необратимости процессов рыночных преобразований и повышает доверие мирового сообщества, потенциальных инвесторов к правительству страны и его экономической политике. Членство в ВТО может стать важнейшим фактором развития внешней торговли и привлечения иностранных инвестиций, увеличения внутренних сбережений и инвестиций, следовательно, и ускорения структурной перестройки и темпов роста экономики Узбекистана.

В целях дальнейшего совершенствования законодательства в области внешнеэкономической деятельности и гармонизации законодательства Республики Узбекистан в рамках соглашений ВТО, предстоит еще проделать большую работу, включая вопросы по правовому оформлению многостороннего сотрудничества в области доступа на рынок услуг.

В этой связи требуется серьезная работа, как в ходе переговорного процесса по вступлению в ВТО, так и в ходе развития национального законодательства Узбекистана с учетом обеспечения интересов и повышения конкурентоспособности национальных поставщиков услуг, с соблюдением норм и правил ВТО.

\section{Резюмe}

В статье дан обзор нормативно-правовых актов, регулирующих вопросы внешнеэкономической деятельности Республики Узбекистан, создания благоприятных предпосылок для дальнейшей реализации осуществляемых социально-экономических реформ в Узбекистане, а также предложения по внесению изменений в национальное законодательство исходя из принципов и норм соглашений ВТО. 
Askar Mirsaidov

\section{International Legal Aspects of the Accession of Uzbekistan to the WTO in the Context of the Review of Legislation on Trade in Services}

The analytical article highlights the main rules and principles of the World Trade Organization (WTO), as well as some aspects of the accession of the Republic of Uzbekistan to the WTO, the legislation of Uzbekistan in the sphere of services, creation of favorable preconditions for further implementation of the ongoing socio-economic reforms in the country, as well as proposals for the correction of the national legislation of Uzbekistan in accordance with the norms and WTP agreements.

KEY WORDS: Uzbekistan, WTO, WTO accession, legislation of Uzbekistan in the sphere of services, foreign economic relations of Uzbekistan

\section{Библиография}

I. Gudkov, N. Mizulin, WTO Rules: Problems of Direct Action and Effectiveness of Measures of Responsibility for Violations, «WTO Law» 2012, № 1.

M. M. Novikov, Regulation of Foreign Trade in the Conditions of Membership in the WTO, Moscow 2005.

V. D. Perevalov, V. I. Sherpayev, L. N. Berg, Problems of Harmonization of Normative Legal Acts of the WTO and the Russian Federation, «WTO Law» 2014, № 1.

N. Sirazhdinov, Liberalization of Foreign Trade Operations the Competitiveness of the National Economy, «Economic Review» 2017, № 11.

E.V. Surko, WTO: Introduction to the Legal System, Moscow 2003. 
Anahit Manasyan

ORCID: 0000-0001-6404-4318

\section{The Issues of Differentiation of Constitutional Policy from Ongoing Politics}

KEY WORDS:

constitutional policy, ongoing politics, Constitution, constitutional stability, symbol of a constitutional system

\section{Introduction}

Many authors believe that constitutional policy thoroughly depends on the ongoing politics. According to them constitutions are subject to political actors and events, exist only during such a timeframe and define just such regulations, within which they are expedient from the political point of view. We believe that such a perception needs to be overcome and rethought. Hence, the differentiation of constitutional policy from ongoing politics is one of the most important issues of the modern legal and political thought and needs complex and thorough analysis.

\section{The Impact of Politics on Constitutional Developments}

A rich intellectual tradition in political science postulates that formal institutions emerge and change as a byproduct of political and social change. The view expressed in literature, according to which the significance of the Constitution is in the fact that it is the real prize of the political struggle, is not accidental ${ }^{1}$. In this

1 See R. Calvert, Coordination and Constitutional Change, Washington University in St. Louis, p. 11, http://calvert.wustl.edu/downloads/CoordConstChg.MPSA.pdf (access: 15.04.2016); Overview of Law and Politics, [in:] R. Goodin (ed.), The Oxford Handbook 
perspective, political actors support a constitution in equilibrium only as long as the underlying configuration of interests and powers that sustains the equilibrium remains stable. Should the interests or resources of powerful actors change, so would the existing constitutional structure ${ }^{2}$. Moreover, the approach that, constitutions are subject to political actors and events and exist just during such a timeframe, within which they are expedient from the political point of view, and no more, has been widely spread ${ }^{3}$. Hence, the important changes of the political and social life increase also the risk of the amendment of the Constitution.

Various research show that the stability of modern constitutions mostly depends on political stability, and the interruption of the balance of the state power in the result of armed upheavals, revolutions, etc. have the greatest impact on decreasing the viability of the Constitution. For example, $66 \%$ of the constitutions of the Latin American countries, which lost their effect in 1946-2000, were replaced just during these events ${ }^{4}$.

In this context the view expressed in literature is worth mentioning, according to which the Constitution has a mixed - political-legal character, hence, the political and legal are closely interrelated within the frames of the Constitution 5 . Moreover, several authors state that constitutionalism is the factual realization of politics expressed in the content of the Constitution ${ }^{6}$. Taking this into consideration, the key elements of the essence of the Constitution are formulated in the form of the following questions: 1 . The will of which political forces has been defined in the Constitution? 2. The interests of which social layers are expressed in constitutional provisions and preserved by them? etc. ${ }^{7}$. According to a number of authors, law cannot exist without politics, as politics gives the law its driving force and its "rough content" or substance, which law then adapts to its autonomous framework and develops its final form, expressing it in a specific normative manner ${ }^{8}$.

of Political Science, 2011, http://www.oxfordhandbooks.com/view/10.1093/oxfordhb/ 9780199604456.001.0001/oxfordhb-9780199604456-e-012?print=pdf, (access: 16.06.2018).

2 See G. L. Negretto, The Durability of Constitutions in Changing Environments: A Study on Constitutional Stability in Latin America, http://verfassungswandel.files.wordpress. com/2008/10/14-negretto-paper.pdf (access: 15.04.2016).

3 D. Oliver, C. Fusaro (eds.), How Constitutions Change (A Comparative Study), Oxford and Portland, Oregon, 2011, p. 115.

4 See G.L. Negretto, The Durability of Constitutions in Changing Environments: A Study on Constitutional Stability in Latin America, http://verfassungswandel.files.wordpress. com/2008/10/14-negretto-paper.pdf (access: 15.04.2016).

5 Sее И. А. Кравец, Российский конституционализм: проблемы становления, развития и осуществления, Санкт-Петербург 2005, p. 148; D. Oliver, C. Fusaro (eds.), How Constitutions Change..., p. 242.

6 Seе Н. Витрук, Конституциионоое правосудие, Москва 2005, p. 144.

7 Seе И. А. Кравец, Российский конституционализм ..., p. 154-155.

8 See M. Cerar, The Relationship Between Law and Politics, «Annual Survey of International \& Comparative Law» 2009, Volume 15, Issue 1, p. 33. 
We also believe that from the viewpoint of the discussed issue politics is an important factor, as the political environment has an undeniable impact on the choice of constitutional solutions and their factual realization. The reason for such a conclusion is obvious, as in almost all modern constitutional systems constitutions are adopted and amended in the result of direct participation of political forces, notwithstanding the fact whether the constitutional regulations are adopted by the parliament ${ }^{9}$, special body established for this $\operatorname{aim}^{10}$, or the people ${ }^{11}$.

For instance, Article 202 of the RA Constitution defines that the Constitution and amendments to Chapters $1-3,7,10$ and 15 of the Constitution, as well as to Article 88, to the first sentence of part 3 of Article 89, to part 1 of Article 90, to part 2 of Article 103, to Articles 108, 115, 119-120, 123-125, 146, 149 and 155, and to part 4 of Article 200 of the Constitution shall be adopted only through a referendum. At least one third of the total number of Deputies, the Government or two hundred thousand citizens having the right of suffrage shall have the right to the initiative of adopting or amending the Constitution. The National Assembly shall adopt the decision on putting the draft to referendum by at least two thirds of votes of the total number of Deputies. Except for the specified Articles, amendments to other Articles of the Constitution shall be adopted by the National Assembly, by at least two thirds of votes of the total number of Deputies. At least one fourth of the total number of Deputies, the Government or one hundred fifty thousand citizens having the right of suffrage shall have the right to corresponding initiative. In case the National Assembly does not adopt the draft of the amendments to the Constitution provided for in part 2 of the mentioned article, it may be put to referendum upon the decision adopted by at least three fifths of votes of the total number of Deputies. Moreover, according to Article 206 of the RA Constitution the President of the Republic shall call a referendum within a period of three days following the adoption by the National Assembly of a decision on holding a referendum.

It should also be noted that the essence of the constitutional regulations itself presupposes that their majority ${ }^{12}$ cannot be implemented without the direct participation of political forces.

9 For instance, in Hungary, now in part also in the Republic of Armenia.

10 For instance, in the Russian Federation the mentioned body is called Constitutional Assembly.

11 Till 06.12.2015 constitutional amendments the RA Constitution could be adopted and amended just via a referendum. In the result of constitutional reforms the RA Constitution prescribed a possibility of amendment of certain constitutional regulations also by the National Assembly.

12 For instance, constitutional regulations concerning organization and activities of the state power bodies, fundamental human and citizen rights and freedoms. 
The presented legal regulations lead us to a conclusion that political forces have direct role with regard to the issues of both the adoption of constitutional amendments, and also of calling a referendum. This role is obvious also from the viewpoint of implementation of constitutional norms.

The circumstance should also be taken into account that in comparison with other institutions and groups, for political forces constitutional developments are primarily necessary for gaining and preserving power, as well as forming and developing a desirable model of separation and balance of powers, which becomes essential from the viewpoint of their whole role in the process of constitutional developments. Hence, it is obvious that three main factors determine the impetus for the mentioned forces: 1 . individual, private interests of the people, representing political forces ${ }^{13}, 2$. partisan interests ${ }^{14}, 3$. public interests. Taking into account the general aims of the activities of political parties, it is naturally impossible to exclude the existence and role of individual or partisan interests in the activities of these forces. Hence, it is obvious that in this context the key objective is to find a proper balance between the mentioned individual and partisan factors and the public interest in the aspect that individual and partisan interests should be secondary, derivative from the public interest and serve the main aim of social systems - the circumstance that the axis, basis of all the social systems is the human being as a highest value, for whom possibilities of self-expression and self-realization should be guaranteed via establishment and strengthening of the rule of law.

The following circumstance is also important in the mentioned context: if constitutional developments are implemented via making amendments to the text of the Constitution, the isolation of political forces, at first, the ruling political force from other political forces and society and the solitary search of constitutional solutions should be excluded during this, as the opposite process always leads to decline in confidence in constitutional regulations and their implementation, hence also, to the absence of constitutional stability. In this aspect the example of constitutional reforms in the South African Republic is interesting, the sucess of which, according to some authors, was conditioned not just by the circumstance of wide public participation, but also by the existence of «enogh inter-partisan consensus» ${ }^{15}$.

13 For instance, attempts of extension of term of office of presidents, which are rather widespread in recent years.

14 For instance, choice of concrete form of governance, concrete electoral system, etc., with the aim of preserving the role of a concrete political force in the system of state power.

15 See M. van Vliet, W. Wahiu, A. Magolowondo, Constitutional Reform ..., p. 12, https://openaccess.leidenuniv.nl/bitstream/handle/1887/30222/ASC-075287668-3333-01.pdf?sequence=1, (access: 16.06.2018). 
The above-mentioned leads us to a conclusion that the political environment has undeniable effect on the choice of constitutional solutions and their factual realization.

\section{Constitution as an Important Phenomenon for Defining the Rules of the Political Game}

In the discussed context we should take into consideration that the impact of politics on constitutional systems isn't unilateral, as the Constitution, in its turn, defines the rules, within the frames of which the state, hence, also the political power should act. From this viewpoint the statement of French prominent lawyer Pierre Sandevuar is interesting, according to which: "It is the politics, which formulates the law, but at the same time, the law itself responds to politics, introducing to it a regulating element and making political actors to act transparently, fairly and responsibly"16. The view expressed in literature, according to which fundamental social changes are possible only via such constitutional changes, which reflect corresponding changes of political culture directed to strengthening constitutionalism, respect towards human and citizen rights and the rule of law, is also interesting ${ }^{17}$.

Therefore, the stability of the Constitution and constitutional system is conditioned not just by this or that change of correlation of political forces, but generally, by the corresponding level of constitutional and political culture of the society. The latter predetermines not just the character of internal constitutional solutions, but also the external factors, having impact on their definition and viability, as well as the methods of reaction to them. It is not accidental that in literature the circumstance that a number of textual amendments are made to the Basic Law even in conditions of rigid constitutions, as for instance, in Germany, Czech Republic, India, South African Republic, is conditioned just by the impact of culture and politics. Whereas, the culture and politics of other states make textual amendments to the Constitution rather difficult or even impossible, for instance, in Italy and Spain ${ }^{18}$. From this viewpoint the approach expressed in literature, according to which the realization and stability of the Constitution depend on the circumstance how much it is accepted and preserved by the state power, and most importantly - by different social groups, is also worth mentioning ${ }^{19}$.

16 Seе П. Сандевуар, Введение в право, Москва 1994, р. 61-64.

17 See M. van Vliet, W. Wahiu, A. Magolowondo, Constitutional Reform..., p. 13.

18 See D. Oliver, C. Fusaro (eds.), How Constitutions Change..., p. 396-397.

19 See Inquiry to Review New Zealand's Existing Constitutional Arrangements, Report of the Constitutional Arrangements Committee, Presented to the House of Representatives, 
Hence, we believe that constitutional and political culture of the society has key significance for the existence of the feature of constitutional stability.

\section{The Common Aim of the Constitution and Politics and its Role for Ensuring the Constitutional Stability}

While differentiating constitutional policy from the ongoing politics, we should be guided by the logic that law and politics should have one main common aim regulation of social relations by guaranteeing the principle of rule of law. And in such conditions it becomes obvious that the Constitution should be not a tool for politics, but a bound, framework for it. Moreover, the constitutional developments should express not the current political preferences and interests, but be superior to them and define fundamental legal framework for political actors and events. In other words, constitutional policy should be clearly differentiated from the current politics, and the Constitution should be not a part of the ongoing political game, but should have a role of defining the rules of that game. It is not accidental that the term "Constitution" is itself etymologized also from the aspect of "limitation", clarification of the limits of power and of establishing "inescapable snare" for all of them, who will try to go out of their authorities prescribed by law ${ }^{20}$. It's worth mentioning in this context that according to various studies in all the situations, when political elites have been trying to use the Constitution with the aim to gain political dominance, the final result has been the paradox "Constitution without constitutionalism" 21 , which, to our mind, is unacceptable from the viewpoint of guaranteeing constitutional stability and stable democracy.

The next conclusion, which is important in this context, is the following: the Constitution should not be subject to amendment parallel to every change of political situation of the state or formation of a new political majority. The Constitution has a fundamental role from the aspect of regulating social relations and can't be used just as a tool for solving ongoing political problems. Moreover, the Constitution is not just a document with a highest legal force, but also a symbol of a concrete constitutional system, and from this viewpoint the Basic Law has a symbolic significance. Hence, the Constitution should in reality be perceived by society as a fundamental document, symbol of the constitutional

Forty-seventh Parliament (Hon Peter Dunne, Chairperson), August 2005, http://www.parliament.nz/NR/rdonlyres/575B1B52-5414-495A-9BAF-C9054195AF02/15160/DBSCH SCR_3229_2302.pdf, p. 7 (access: 04.02.2015).

20 See $\bar{G}$. Harutyunyan, Constitutional Culture: the Lessons of History and the Challenges of Time, Yerevan 2017, p. 22.

21 See M. van Vliet, W. Wahiu, A. Magolowondo, Constitutional Reform..., p. 12. 
system, should create a feeling of the factually existing constitutionalism, and not of a political declaration accidentally adopted or amended parallel to each political event. Hence, the frequency of constitutional amendments can't be conditioned just by the balance of political forces and its mathematical calculation. The ways of constitutional amendments and the process of their realization should form such a public perception that the Constitution is a stable document, symbol of a concrete constitutional system and cannot be amended just based on the political will of the political majority of the day. The opposite situation can make the proper realization of constitutional norms impossible and lead to distortion of values, underlying constitutional stability, as well as of such values, underlying the Rule-of-Law State, as predictability and legal certainty, excluding also the perception of the Constitution as a symbol of a concrete constitutional system.

The Venice Commission has continuously stated regarding the discussed issue that too frequent changes of the Constitution have negative impact from the viewpoint of constitutional and political stability ${ }^{22}$. Moreover, the Commission regrettably emphasized on the constitutional amendments in Croatia that during a very short timeframe 23 the Constitution was amended two times, not giving an opportunity to use the possibilities provided by the first amendment ${ }^{24}$.

\section{Conclusions}

Summarizing the implemented analysis, it should be noted that Constitution and politics should have one main common aim - regulation of social relations via guaranteeing the principle of rule of law. In such conditions it becomes obvious that the Constitution should be not a tool for politics, but a bound, framework for it. Moreover, the constitutional developments should express not the current political preferences and interests, but be superior to them and define fundamental legal framework for political actors and events. In other words, constitutional policy should be clearly differentiated from the current politics, and the Constitution should be not a part of the ongoing political game, but should have a role of defining the rules of that game. The Constitution should not be subject to amendment parallel to every change of political situation of the state or formation of

22 See CDL-AD(2010)001, Report on Constitutional Amendment, Adopted by the Venice Commission at its 81st Plenary Session (Venice, 11-12 December 2009), http://www. venice.coe.int/docs/2010/CDL-AD\%282010\%29001-e.pdf, (access: 20.01.2018).

23 The point is on 2000 and 2001 constitutional amendments.

24 See CDL-PI(2015)023, Compilation of Venice Commission Opinions concerning Constitutional Provisions for Amending the Constitution, European Commission for Democracy through Law (Venice Commission), Strasbourg, 22 December 2015, http://www.venice. coe.int/webforms/documents/?pdf=CDL-PI(2015)023-e, (access: 16.06.2018). 
a new political majority. The Basic Law has a fundamental role from the aspect of regulating social relations and can't be used just as a tool for solving ongoing political problems. It is a symbol of a concrete constitutional system, and should in reality be perceived as such.

\section{RÉSUMÉ}

The article considers the issues of differentiation of constitutional policy from ongoing politics. The author concludes that Constitution and politics should have one main common aim - regulation of social relations via guaranteeing the principle of rule of law. The Constitution should be not a tool for politics, but a bound, framework for it. Moreover, the constitutional developments should express not the current political preferences and interests, but be superior to them and define fundamental legal framework for political actors and events. In other words, constitutional policy should be clearly differentiated from the current politics, and the Constitution should be not a part of the ongoing political game, but should have a role of defining the rules of that game. The Constitution should not be subject to amendment parallel to every change of political situation of the state or formation of a new political majority. The Basic Law has a fundamental role from the aspect of regulating social relations and can't be used just as a tool for solving ongoing political problems. It is a symbol of a concrete constitutional system, and should in reality be perceived as such.

\section{Bibliography}

R. Calvert, Coordination and Constitutional Change, Washington University in St. Louis, http://calvert.wustl.edu/downloads/CoordConstChg.MPSA.pdf, (access: 15.04.2016).

M. Cerar, The Relationship Between Law and Politics, «Annual Survey of International \& Comparative Law» 2009, Volume 15, Issue 1.

CDL-AD(2010)001, Report on Constitutional Amendment, Adopted by the Venice Commission at its 81st Plenary Session (Venice, 11-12 December 2009), http://www.venice.coe.int/ docs/2010/CDL-AD\%282010\%29001-e.pdf, (access: 20.01.2018).

CDL-PI(2015)023, Compilation of Venice Commission Opinions concerning Constitutional Provisions for Amending the Constitution, European Commission for Democracy through Law (Venice Commission), Strasbourg, 22 December 2015, http://www.venice.coe.int/ webforms/documents/?pdf=CDL-PI(2015)023-e, (access: 16.06.2018).

G. Harutyunyan, Constitutional Culture: the Lessons of History and the Challenges of Time, Yerevan 2017.

D. Oliver, C. Fusaro (eds), How Constitutions Change (A Comparative Study), Oxford and Portland, Oregon 2011.

Inquiry to Review New Zealand's Existing Constitutional Arrangements, Report of the Constitutional Arrangements Committee, Presented to the House of Representatives, 
Forty-seventh Parliament (Hon Peter Dunne, Chairperson), August 2005, http://www.parliament.nz/NR/rdonlyres/575B1B52-5414-495A-9BAF-C9054195AF02/15160/DBSCH_ SCR_3229_2302.pdf, (access: 04.02.2015).

I. A. Kravets, Russian Constitutionalism: Problems of Formation, Development, and Implementation, St. Petersburg 2005.

G. L. Negretto, The Durability of Constitutions in Changing Environments: A Study on Constitutional Stability in Latin America, http://verfassungswandel.files.wordpress. com/2008/10/14-negretto-paper.pdf, (access: 15.04.2016).

P. Sandevoire, Introduction to the Law, Moscow 1994.

N. Vitruk, Constitutional Justice, Moscow 2005.

M. van Vliet, W. Wahiu, A. Magolowondo. Constitutional Reform Processes and Political Parties: Principles for Practice, https://openaccess.leidenuniv.nl/bitstream/handle/1887/30222/ ASC-075287668-3333-01.pdf?sequence=1, (access: 16.06.2018). 


\title{
Problems of interpretation of law in accordance with the Constitution - Polish construction in historical and comparative aspects
}

\author{
KEY WORDS: \\ Constitution, Constitutional Court, interpretation of the Constitution, \\ interpretation in harmony with the Constitution
}

\section{Introduction}

In the light of art. 188 of the Constitution of the Republic of Poland ${ }^{1}$ The Constitutional Court adjudicates on the compliance of laws and other normative acts with the Constitution. The interpretation of law in accordance with the Constitution has been a key issue since the beginning of the jurisprudential activity of Polish Constitutional Court and it is a term that is part of the legal language. According to Andrzej Bator and Artur Kozak, "the Constitutional Court and other law enforcement bodies do not have the competence - defined in a legal act - to interpret acts of law »in accordance with the Constitution «" 2 . However, it is difficult to imagine that it would be possible to assess the conformity of legal norms without establishing their content, and thus without interpreting them. Since the Constitution in the above-mentioned provision speaks of adjudicating on the compliance of laws and other acts with the Constitution, how can this be done without prior interpretation of the template and without understanding the object of the control? The interpretation of law amounts to reconstructing the norms from the laws and legal acts and determining their significance. The result of

1 Constitution of the Republic of Poland of April 2, 1997 (Journal of Laws of August 16, 1997, No. 78, item 483).

2 A. Bator, A. Kozak, Wyktadnia prawa $w$ zgodzie z konstytucja, [in:] S. Wronkowska (ed.), Polska kultura prawna a proces integracji europejskiej, Cracow 2005, p. 54. 
these interpretations is part of this control, and such a position was adopted by the Constitutional Court. In one of its judgments, it stated that the subject of control is a legal norm, the content and meaning of which has been reconstructed and established through the application of appropriate interpretative and inferential rules. "Among several possible meanings of the provision established through the rules of interpretation, a normative sense should always be sought, which allows for a law to be agreed with the constitution [systemic aspect of interpretation]. Such a position is in full harmony with the presumption of conformity of the statutory norm with the Constitution, universally accepted in constitutional caselaw." 3 The Constitutional Court appealed in its ruling to the inference of the norms, but it did not specify their nature or their relation to other methods of interpretation, so it can be supposed that it assumed inference rules based on some norms resulting from other norms, as well as those "resulting" from axiological assumptions.

\section{At the source of the constitutional interpretation - American practice}

The Constitution of the United States of America was enacted in the Constitutional Convention in 1787 and entered into force after its ratification by the states on July 26, 1788. It is stressed on the ground of the American doctrine that the problem of interpreting law in line with the constitution raises the need to compare the content of a controlled act with its constitutive pattern. It cannot always be clearly stated whether the audited act is compatible / incompatible with the constitution because of the ambiguity of the expressions used there and the role of a court is to harmonize the legal system with constitutional legislation. This type of interpretation was defined as an interpretation in harmony with the Constitution. In many cases a legal article cannot be understood without interpretation. Antonin Scalia and Bryan A. Garner believed that any attempt to establish the linguistic content of a basic editorial unit of a legal act by means of grammar and meaning rules is already a manifestation of a legal interpretation ${ }^{4}$. In order to avoid doubts whether the acts are in line with the constitution, the theory of avoiding constitutional doubts (avoidance doctrine) was adopted. It has been recognized as one of the canvases of legal interpretation. The authors gave this principle the name of Constitutional-Doubt Canon. It corresponds with the principle of presumption of validity, indicating the priority of such a result of an

3 Judgment of the Constitutional Court of November 8, 2000, ref. SK 18/99, p. 21.

4 See A. Scalia, B. A. Garner, Reading Law: The Interpretation of Legal Text, St. Paul 2012, p. 53. 
interpretation that allows the analyzed provision to be maintained in force 5 . This technique was applied in the case of Marbury $v$. Madison, which is considered to be the beginning of judicial review of the constitutionality of legal acts. „When a court applies the avoidance canon to reject the court's otherwise-preferred reading of a statue in favor of a construction that is less constitutionally dubious, the court has made constitutional decision. [...] Such a decision is not only perfectly legitimate, but it also is a useful mechanism for realizing important constitutional values" 6 . In the so-called hard cases - ones that are particularly complicated, or difficult due to different moral judgments involved, the court may face the necessity of choosing between two possible interpretations. One of them may correspond to the values accompanying the creation of a law by the legislator, the second - to the values found by the court through interpreting the constitution 7 . The dispute about the validity of such values and how to interpret them using the constitution lies at the basis of the interpretation itself ${ }^{8}$. American constitutionalism, much earlier than the European doctrine, faced the problem of the activist - passivist interpretation of the constitution. One can briefly summarize this argument by referring to the statements of two judges of the Supreme Court in the USA: Charles Evans Hughes and Felix Frankfurter.

According to the first one: "We are subject to the Constitution, but the judges say what the Constitution is." For the second: "The final touchstone of constitutionality is what the constitution says, not what the judges have said about it"9. These aphoristic statements are an example of the clash in American constitutionalism of the two concepts of constitutional interpretation: Living Constitution and Originalism. Nowadays, one can see the emergence of the third way of interpreting the constitution which allows to eliminate the shortcomings of the two mentioned above. This concept, referred to as Non Originalism (or Living Originalism), allows us to go beyond the text of the constitution and the intention of the Founding Fathers ${ }^{10}$.

5 Ibidem, p. 247.

6 E. A. Young, Constitutional Avoidance, Resistance Norms and the Preservation of Judicial Review, «Texas Legal Review» 2000, vol. 78, p. 1585.

7 See. B. L. Ross, Against Constitutional Mainstreaming, «University of Chicago Legal Review» 2011, vol. 78, p. 1206.

8 L. D. Jellum, The Theories of Statutory Construction and Legislative Process in American Jurisprudence, [in:] M. Araszkiewicz, K. Płeszka (eds.), Logic in the Theory and Practice of Lawmaking, Heidelberg-New York-Dordrecht-London 2015, p. 173-202.

9 I quote: B. Banaszak, M. Bednarczyk, Aktywizm sędziowski we wspótczesnym państwie demokratycznym, Warsaw 2012, p. 63. For more on this subject, see Judical Acitivism v. Judicial Restraint: P. Laidler, Sąd Najwyższy Stanów Zjednoczonych Ameryki: od prawa do polityki, Cracow 2011, p. 234-246.

10 J. M. Balkin, Living Originalism, Cambridge-London 2011, passim. 


\section{The interpretation of law in accordance with the constitution - European practice}

The model of judicial review was adopted in the USA whereas the model of the constitutional court was introduced in Europe. The idea of constitutional judiciary appeared during the Spring of Nations in German countries and in Austria. Austria is widely regarded as the cradle of constitutional judiciary. The concept of protection of the constitution by the court independent of the judiciary appeared for the first time in the draft of the Frankfurt Constitution of 1849, designed for the united German empire, and in the constitution for Austrian countries - passed almost simultaneously in Kroměříž. . Both constitutions were a systemic projection of the concept of the rule of law (Rechtsstaat) created by German liberal thought and the theories of state law. They did not enter into force, but they determined in a visionary way the direction of systemic transformations in these countries ${ }^{11}$. On December 21, 1867, the Basic Law of the State was passed, in which, inter alia, the general rights of citizens were defined and the State Tribunal (Reichsgericht) - the precursor of Austrian constitutional court, was established ${ }^{12}$. After the end of the First World War and the abdication of Habsburg rule after 500 years, a special role was to be played by Hans Kelsen who introduced several versions of the new Constitution of the Republic of Austria and designed a system of constitutional review of laws later called the "Kelsene regime". In his proposal, he made a provision that the decisions of this body will be legally binding and irrevocable. This led to the elimination by the court of unconstitutional norms from the system of applicable law with the effect of erga omnes. He provided the Constitutional Court with the power to scrutinize abstractly the legality of legal acts in terms of their compliance with the Constitution ${ }^{13}$. It was not until the 1960s that the so-called interpretation of laws in accordance with the Constitution appeared in the case-law of this body14. Within its framework, the Court indicates in its opinion an appropriate "interpretation of constitutional

11 A. Dziadzio, Ochrona konstytucyjności prawa w Europie XIX wieku, «Studia z Dziejów Państwa Polskiego» 2008, item. 11, pp. 170-171. Electronic version: [http://bazhum. muzhp.pl/media//files/Studia_z_Dziejow_Panstwa_i_Prawa_Polskiego/Studia_z_Dziejow_ Panstwa_i_Prawa_Polskiego-r2008-t11/Studia_z_Dziejow_Panstwa_i_Prawa_Polskiegor2008-t11-s169-183/Studia_z_Dziejow_Panstwa_i_Prawa_Polskiego-r2008-t11-s169-183. pdf (access: 16.06.2018).

12 Z. Czeszejko-Sochacki, Sądownictwo konstytucyjne w Polsce na tle porównawczym, Warsaw 2003, p. 18; K. Grzybowski, Galicja 1848-1914. Historia ustroju politycznego na tle historii ustroju Austrii, Cracow-Wrocław-Warsaw 1959, p. 106; A. Dziadzio, Monarchia konstytucyjna w Austrii 1867-1914. Władza - obywatel - prawo, Cracow 2001, p. 49 and n.

13 H. Kelsen, Istota i rozwój sądownictwa konstytucyjnego, Warsaw 2009, passim.

14 VfSlg 2264/1952, 3151/1957, 3556/1959 - I quote B. Banaszak, M. Bednarczyk, Aktywizm sędziowski..., p. 140-141. 
norms or statutory norms by specifying what interpretation should be rejected or what should be applied" 15 . This method of interpretation is recognized in law sciences as legitimate. It prevents the repeal of acts in a situation where they can be given a content consistent with the Constitution. Some authors, fearing excessive activism of the Court, warn that the competence of this body does not include giving an act of law, by its own interpretation, the opposite meaning to the one explicitly assigned by the legislator. "An interpretation in accordance with the Constitution - properly applied - should not lead to the development of statutory norms through judicial decisions"16.

The catalog of fundamental rights of the citizens (Grundrechte) had already been broadly defined in the draft of the Frankfurt Constitution of German Empire17. In the light of $\S 194$ of this constitution, no provision in the constitution or statute of the federal state could be in conflict with the federal constitution (principle of the primacy of the constitution). No other act (constitution or national law) could either reduce or repeal the fundamental rights of an individual envisaged in the Reich Constitution ( $(130)$. The Reichsgericht was to guard the observance of federal constitution and the civil rights and freedoms contained there. By virtue of the powers conferred upon it, the Reichsgericht basically considered all the matters related to the interpretation of the constitution. The Reichs' Court was equipped with the possibility of exercising an abstract review of the compliance of laws with the Constitution, not only on the basis of a complaint lodged by authorized state authorities, but also at the request of every citizen.

The revolution of 1848 led to the return of autocratic rule. The subsequent constitutions of 1850 and 1871 did not refer to the solutions of the Frankfurt constitution, they were imposed by the monarch (octroyed constitutions). This situation changed in 1919 with the adoption of the Weimar Constitution which, from the point of view of a legislative technique, was a coherent and clear act ${ }^{18}$. It regulated the Reich's political system, the structure and competences of its various organs, as well as the issues of citizens' rights and obligations. However, the time of crisis in which Germany was at that time meant that this act could not fulfill its role. Thomas Mergel stated that the very modern and high-level solutions that were introduced there proved to be insufficient. According to him, only good law

15 Ibidem, p. 141.

16 H. Schäffer, Verfassungsgericht und Gesetzgebung, [in:] H. Schäffer, W. Berka, H. Stolzlechner, J. Werndl (eds.), Staat - Verfassung - Verwaltung. Festschrift anlässlich des 65. Geburtstages von Prof. D.Dr. D.Dr. H. c. Friedrich Koja, Wien-New York 1998, p. 126.

17 Ibidem, p. 9.

18 For more information on the Weimar Republic's legal solutions, see T. Kotłowski, Historia Republiki We-imarskiej (1919-1933), Poznan 1991 together with the literature cited there; M. Labijak, Rozwiazania prawno-ustrojowe Republiki Weimarskiej w perspektywie historycznej i porównawczej, «Studia Iuridica Toruniensia» 2014, vol. 14, p. 173-192. 
is not enough in the democratic system since good will is needed to implement this law through a democratic path ${ }^{19}$. Paradoxically, this most democratic German constitution led to the creation of a system of totalitarian rule.

According to Domenique Rousseau, the lack of judicial control over the constitutionality of the law led to the overthrow of democracy in Germany. The cataclysm of fascism and Nazism ruined constitutional theories based on the primacy of the constitutional $\mathrm{law}^{20}$. As the founders of the Basic Law of the Federal Republic of Germany of May 23, 1949 were conscious of that, they adopted the solutions of the Austrian model whose essence was the examination of the conformity of legal acts with the constitution. At the same time they "decided to expand the competences of the newly created Federal Constitutional Court in accordance with the contrary American model, allowing for the examination of the constitutionality of the application of law" 21 . The result was the establishment of The Constitutional Court with a much broader competence, effective procedures and a relatively broad availability compared to the Constitutional Court of the Republic of Austria.

According to art. 92 of German Basic Law, The Federal Constitutional Court is an organ of the judiciary. It is listed first before the Supreme Court and other federal and national courts. The legislator emphasized its primary role in the system of state authorities of Germany. The Basic Law itself devoted only two articles to this body (Articles 93 and 94). The Law on the Federal Constitutional Court was its development in which it was unequivocally stated that this body is "independent in relation to all constitutional order „,( $(1 \text { section } 1)^{22}$. The Constitutional Court is inscribed in the "liberal democratic order"23. Its task is to create a constitutional consensus. It does so by interpreting the constitution and examining the conformity of legal acts with the constitution. The main reason for this form of adjusting the law to the changing social and cultural-ethical reality is the openness of normative acts, their ambiguity, generality and their multiple reference. This is especially visible in basic rights whose specifying is an interpretation of the constitution. It is even claimed that they are offer

19 T. Mergel, Dictatorship and Democracy (1918-1939), [in:] H. W. Smith (ed.), The Oxford Handbook of Modern German History, Oxford 2011, p. 435-436.

20 See D. Rousseau, Sadownictwo konstytucyjne w Europie, Warsaw 1999, p. 23.

21 D. Janicka, Ustawa Zasadnicza w praktyce Republiki Federalnej Niemiec (1949-1989), Toruń 2009, p. 244.

22 Gesetz über das Bundesverfassungsgericht vom 12. März 1951, BGBI. I, 243 (consolidated text: Bekanntmachung der Neufassung des Gesetzes über das Bundesverfassungsgericht vom. 3. Februar 1971, BGBI. I, 105); J. Trzciński (ed.), Sądy konstytucyjne w Europie, vol. 1, Austria, Francja, Niemcy, Włochy, Warsaw 1996, p. 152-207.

23 G. Kellermann, Verfassungsinterpretation. Das Grundgesetz als normative Ressource im gesellschaftlichen Wandel, Schwalbach 2011, p. 19. 
a possibility for future interpretations, which, in the long term, secure political and social changes ${ }^{24}$.

\section{Interpretation of the constitutional act}

A particular problem related to the interpretation of the constitution is that we must not depart from the clause of literal understanding of the text. This is due, on the one hand, to the positivity of the law and, on the other, to the functions that are imposed on modern constitutions. Undoubtedly, each interpretation assumes the stability of the text (maintaining its original meaning), but it is possible to understand it better by making an interpretation ${ }^{25}$. It should be borne in mind that written texts (laws, the constitution) depend on the meanings derived by means of legal interpretation. As in the case of ordinary acts whose general parts determine the interpretation standards for their specific parts, the constitution is the highest level of standards for all other acts. Thanks to this, the entire legal system is provided with stability and also flexibility (it allows to adjust each act of law to life without having to change the foundations of the legitimacy of the legal system). The concern over the stability of the constitution gives rise to the fear of political arbitrariness. The fact that the constitution is an act of the highest rank in the system of positive law does not mean, in the light of the arguments of some authors, that its interpretation should be limited. It should rather "be made free from these ties" 26 .

Gero Kellermann wrote that the discussion on the correct methods of interpreting the constitution is the "Archimedes point" of constitutional law. "The interpreting body adapts the content of the constitution (and its consequences) to the stage of social life" 27 . The need to update this consensus, especially in a conflict situation, is an open process. The key to solving it is a reasonable interpretation of constitutional provisions, which, on the one hand must take into account the changes taking place, and on the other - justice, while keeping these variables in equilibrium. The role of interpreting the constitution boils down to defining the goal of the legislator and policies corresponding to constitutionality. Ethical and cultural problems such as human dignity, freedom and security, as well

24 R. Wahl, Verfassungsänderung - Verfassungswandel - Verfassungsinterpretation, [in:] Verfassungsänderung, Verfassungswandel, Verfassungsinterpretation: Vorträge bei deutsch - japanischen Sympozien in Tokyo 2004 und Freiburg 2005, Berlin 2008, p. 29.

25 G. Roellecke, Das Paradox der Verfassungsauslegung, Paderborn-München-Wien-Zürich 2012, p. 8.

26 Ibidem, p. 10.

27 G. Kellermann, Verfassungsinterpretation ...., p. 25. 
as the problems of marriage and family, and the discussions emerging in these matters, indicate that it is difficult to bring about their unanimous synchronization (compatibility) with the constitution ${ }^{28}$.

In constitutional systems with strong constitutional jurisdiction (e.g. the Federal Republic of Germany), the Constitutional Court plays a large role in determining the forms and methods of interpreting the law. The construction and reconstruction of the constitutional interpretation carried out by this body has long been the subject of scientific and political disputes. One of the ways to solve them is an interpretation referring to the specific will of the historical constitutional legislator. The original intention must be determined in each case separately. The Federal Constitutional Court expressed the opinion that the "objective will of the legislator" or "the will of the law" should be taken into account in resolving any constitutional issues. This allows to adjust the constitutional law to changing social and technological conditions ${ }^{29}$. Therefore, it is permissible to "develop" the Constitution through its interpretation, which raises the question of whether we are dealing with specific methods of constitutional interpretation.

The necessity to turn to the goal or intent of the legislator or the act raises the need for many methods of interpretation, which include the following: grammatical, systemic, functional (teleological), and historical methods ${ }^{30}$. This division was introduced into German literature by Friedrich Carl von Savigny and it is still functioning today ${ }^{31}$. These methods are used when interpreting all legal norms. However, the interpretation of constitutional norms in the light of the prevailing view is in many respects specific in its nature - the specificity of the language, its political character, openness to fundamental rights and the axiology contained there - determine its unique nature. After all, it refers to the law as an "abstract composition" that safeguards the development of fundamental rights. The interpretation can therefore be treated as a kind of an expert opinion with the legal value. Although it is based on traditional methods, they refer to constitutional law whose peculiarity determines the specific character of constitutional interpretation. This interpretation includes:

- the principle of unity of the constitution - its aim is to avoid contradictions between constitutional norms;

- the principle of practical agreement - its aim is to achieve optimal effectiveness;

- the principle of functional correctness - it manifests itself in the fact that the constitution has been interpreted by a non-legislator, but the non-legislator's competences set out in the constitution make this body's activity appropriate;

28 Ibidem.

29 Ibidem, p. 26-27.

30 Ibidem, p. 27.

31 F. C. von Savigny, System des heutigen Römischen Rechts, vol. 1, Berlin 1840. 
- the principle of action integration - its aim is to provide an advantage of such an interpretation that is an expression of a harmonization of the results obtained through these different methods;

- the principle of a normative life of the constitution - this is not about the effectiveness of normative regulations, but about their control from the point of view of axiological assumptions that have been expressed in fundamental rights and in the principles of organizational and legal Grundnorm of the political order of the state ${ }^{32}$.

These basic principles form an integral part and the core of each democratic and political order. Their function is to defend against unjustified interference of the state with fundamental rights guaranteed by the constitution.

\section{Final remarks}

The activity of the Federal Constitutional Court of Germany and the achievements of the constitutional law in this country had the greatest influence on Polish judicial practice ${ }^{33}$. The Polish name of this institution is a translation of the German term fervassungskonforme Auslegung von Gesetzen. In the initial years of its activity the Federal Constitutional Court limited itself only to the analysis of whether the statutory norms examined by it were compatible / inconsistent with the Basic Law ${ }^{34}$. Starting from the 1960s, it has also adjudicated on partial unconstitutionality. Undoubtedly, the recognition of a partial unconstitutionality of a norm leads to a change in its content. Among the meanings that could have been assigned to it earlier one distinguishes the meaning that is consistent in its content with the constitution, and rejects those meanings that have been considered inconsistent by the Court.

The Polish Constitutional Court has been included in the judiciary, but it does not exercise the judiciary. It has a fairly wide margin of freedom when interpreting the constitution. Piotr Tuleja noted that "the legitimization of constitutional judiciary does not result only from the reference to the formal aspect of being bound by law, including the Constitution, but it has been based on substantive understanding of the rule of law. The principle of the rule of law, in its material content, means first of all the priority of an individual over the state and limiting the freedom of each individual by the state only to the necessary extent. On the

32 G. Kellermann, Verfassungsinterpretation..., p. 27-28.

33 Z. Czeszejko-Sochacki, Orzeczenia Trybunatu Konstytucyjnego: pojęcie, klasyfikacja, skutki, «Państwo i Prawo» 2000, item. 12, p. 22.

34 See T. Maunz, G. Dürig et al., Grundgesetz Kommentar, München 1958, commentary to art. 100. 
basis of this principle, the Constitutional Court is perceived as a guardian of the constitution, that is, the body which, based on the provisions of the constitution, determines the acceptable extent of the interference of the state in each individual's freedom" 35 .

Assessing whether an interpretation complies with the constitution is not a simple or unambiguous procedure ${ }^{36}$. Some experts treat this interpretation as a technique of a system interpretation ${ }^{37}$, others - functional interpretation ${ }^{38}$. The distinction of this type of interpretation as an independent method / technique of interpretation, however, seems to be disputable. In the literature on the subject, interpretation in accordance with the constitution is presented as a kind of operative interpretation ${ }^{39}$. It is indicated that it is functionally coupled with the decision-making process. The Constitutional Court acts in this matter within its constitutionally acquired competence. However, the difference between this court and other courts as well as other law enforcement institutions lies in the fact that the process of the court's operationalization of the interpretation of law is abstract ${ }^{40}$.

The USA is the only country where a specific interpretation of law was created along with methods complying with the constitution. This is the concept of originalism ${ }^{41}$ - a specific construction only for the interpretation of this act. Another concept of interpretation - textualism - refers to the interpretation of laws $^{42}$. In none of the three countries: Austria, Germany or Poland, a different concept of interpretation was created that would include methods designed only for the interpretation of the constitution. While examining the conformity of legal acts with the constitution, one can note, however, that more emphasis is put in these countries on systemic, functional or teleological methods, which generates the problem of the peculiarity and autonomy of such an interpretation ${ }^{43}$.

35 P. Tuleja, Stosowanie Konstytucji RP w świetle zasady jej nadrzędności (wybrane problemy), Cracow 2003, p. 187.

36 A. Bator, A. Kozak, Wyktadnia prawa ..., p. 44-51.

37 See L. Morawski, Wykładnia w orzecznictwie sądów. Komentarz, Toruń 2002, p. 168 and n.

38 P. Tuleja, Stosowanie Konstytucji RP..., p. 308.

39 T. Stawecki, Operatywna wykładnia konstytucji w świetle badań empirycznych, [in:] L. Leszczyński, A. Szot (eds.), Wykładnia operatywna prawa - perspektywa teoretyczna i dogmatyczna, Toruń 2017, p. 49-73.

40 A. Bator, A. Kozak, Wyktadnia prawa..., p. 57.

41 See A. Scalia, Originalism: The Lesser Evil, «University of Cincinnati Law Review» 1988-1989, vol. 57; idem, A Matter of Interpretation: Federal Courts and the Law, Princeton 1997, passim; J. M. Balkin, Living Originalism ..., passim.

42 See J.T. Hutchens, A New Textualism: Why Textualists Should Not Be Originalists, «Kansas Journal of Law \& Public Policy» 2006-2007, vol. 16, no. 2.

43 See. collections of studies on this subject (I limit myself to Polish literature): T. Stawecki, J. Winczorek (eds.), Wyktadnia Konstytucji. Inspiracje, teorie, argumenty, Warsaw 2014; M. Smolak (ed.), Wyktadnia Konstytucji. Aktualne problemy i tendencje, Warsaw 2016; M. Hermann. S. Sykuna (eds.), Wykładnia prawa. Tradycja i perspektywy, Warsaw 2016. 


\section{RÉSUMÉ}

In the light of art. 188 of the Constitution of the Republic of Poland The Constitutional Court adjudicates on the compliance of laws and other normative acts with the Constitution. The interpretation of law in accordance with the Constitution has been a key issue since the beginning of the jurisprudential activity of Polish Constitutional Court. It is stressed on the ground of the American doctrine that the problem of interpreting law in line with the constitution raises the need to compare the content of a controlled act with its constitutive pattern. This type of interpretation was defined as an interpretation in harmony with the Constitution. In American constitutionalism two concepts of constitutional interpretation can be distinguish: Living Constitution and Originalism. Nowadays, one can see the emergence of the third way of interpreting the constitution which allows to eliminate the shortcomings of the two mentioned above. This concept, referred to as Non Originalism (or Living Originalism). The model of judicial review was adopted in the USA whereas the model of the constitutional court was introduced in Europe. Austria is widely regarded as the cradle of constitutional judiciary. Hans Kelsen designed a system of constitutional review. He provided the Constitutional Court with the power to scrutinize abstractly the legality of legal acts in terms of their compliance with the Constitution. It was not until the 1960s that the so-called interpretation of laws in accordance with the Constitution appeared in the case-law of this body. The cataclysm of fascism and Nazism ruined constitutional theories based on the primacy of the constitutional law. As the founders of the Basic Law of the Federal Republic of Germany of May 23, 1949 were conscious of that, they adopted the solutions of the Austrian model whose essence was the examination of the conformity of legal acts with the constitution. The discussion on the correct methods of interpreting the constitution is the "Archimedes point" of constitutional law. The activity of the Federal Constitutional Court of Germany and the achievements of the constitutional law in this country had the greatest influence on Polish judicial practice. The Polish name of this institution is a translation of the German term fervassungskonforme Auslegung von Gesetzen.

\section{Bibliography}

J. M. Balkin, Living Originalism, Cambridge-London 2011.

B. Banaszak, M. Bednarczyk, Aktywizm sędziowski we współczesnym państwie demokratycznym, Warsaw 2012.

A. Bator, A. Kozak, Wyktadnia prawa w zgodzie z konstytucja, [in:] S. Wronkowska (ed.), Polska kultura prawna a proces integracji europejskiej, Cracow 2005.

Z. Czeszejko-Sochacki, Sądownictwo konstytucyjne w Polsce na tle porównawczym, Warsaw 2003.

A. Dziadzio, Monarchia konstytucyjna w Austrii 1867-1914. Władza - obywatel - prawo, Cracow 2001.

A. Dziadzio, Ochrona konstytucyjności prawa w Europie XIX wieku, «Studia z Dziejów Państwa Polskiego» 2008, item. 11. 
K. Grzybowski, Galicja 1848-1914. Historia ustroju politycznego na tle historii ustroju Austrii, Cracow-Wrocław-Warsaw 1959.

M. Hermann S. Sykuna (eds.), Wyktadnia prawa. Tradycja i perspektywy, Warsaw 2016.

J. T. Hutchens, A New Textualism: Why Textualists Should Not Be Originalists, «Kansas Journal of Law \& Public Policy» 2006-2007, vol. 16, no. 2.

L. D. Jellum, The Theories of Statutory Construction and Legislative Process in American Jurisprudence, [in:] M. Araszkiewicz, K. Płeszka (eds.), Logic in the Theory and Practice of Lawmaking, Heidelberg-New York-Dordrecht-London 2015.

G. Kellermann, Verfassungsinterpretation. Das Grundgesetz als normative Ressource im gesellschaftlichen Wandel, Schwalbach 2011.

H. Kelsen, Istota i rozwój sądownictwa konstytucyjnego, Warsaw 2009.

M. Labijak, Rozwiazania prawno-ustrojowe Republiki Weimarskiej w perspektywie historycznej i porównawczej, «Studia Iuridica Toruniensia» 2014, vol. 14.

P. Laidler, Sad Najwyższy Stanów Zjednoczonych Ameryki: od prawa do polityki, Cracow 2011.

T. Maunz, G. Dürig et al., Grundgesetz Kommentar, München 1958.

L. Morawski, Wykładnia w orzecznictwie sądów. Komentarz, Torun 2002.

G. Roellecke, Das Paradox der Verfassungsauslegung, Paderborn-München-Wien-Zürich 2012.

B. L. Ross, Against Constitutional Mainstreaming, «University of Chicago Legal Review» 2011, vol. 78.

F.C. v Savigny, System des heutigen Römischen Rechts, vol. 1, Berlin 1840.

A. Scalia, A Matter of Interpretation: Federal Courts and the Law, Princeton 1997.

A. Scalia, Originalism: The Lesser Evil, «University of Cincinnati Law Review» 1988-1989, vol. 57.

A. Scalia, B. A. Garner, Reading Law: The Interpretation of Legal Text, St. Paul 2012.

Schäffer H., Verfassungsgericht und Gesetzgebung, [in:] H. Schäffer, W. Berka, H. Stolzlechner, J. Werndl (eds.), Staat - Verfassung - Verwaltung. Festschrift anlässlich des 65. Geburtstages von Prof. D.Dr. D.Dr. H. c. Friedrich Koja, Wien-New York 1998.

M. Smolak (ed.), Wyktadnia Konstytucji. Aktualne problemy i tendencje, Warsaw 2016.

T. Stawecki, Operatywna wykładnia konstytucji w świetle badań empirycznych, [in:] L. Leszczyński, A. Szot (eds.), Wykładnia operatywna prawa - perspektywa teoretyczna i dogmatyczna, Torun 2017.

T. Stawecki, J. Winczorek (eds.), Wyktadnia Konstytucji. Inspiracje, teorie, argumenty, Warsaw 2014.

P. Tuleja, Stosowanie Konstytucji RP w świetle zasady jej nadrzędności (wybrane problemy), Cracow 2003.

R. Wahl, Verfassungsänderung - Verfassungswandel - Verfassungsinterpretation, [in:] Verfassungsänderung, Verfassungswandel, Verfassungsinterpretation: Vorträge bei deutsch - japanischen Sympozien in Tokyo 2004 und Freiburg 2005, Berlin 2008.

E. A. Young, Constitutional Avoidance, Resistance Norms and the Preservation of Judicial Review, «Texas Legal Review» 2000, vol. 78. 


\section{Changes in political relevance of The League of Polish Families in result of parliamentary, municipal and European elections}

The League of Polish Families, political relevance, elections

KEY WORDS:

The League of Polish Families, political relevance, elections

\section{Introduction}

The League of Polish Families was founded in 2001 as the continuation of the National Party (SN) and the National-Democratic Party (SND)- groups that referred to the inter-war ideology of the National Democracy Party. The activists from SN and SND became its leaders: Marek Kotlinowski became the head of the Central Board and Roman Giertych became the head of the Committee, whereas Zygmunt Wrzodak, leader of 'Solidarność' in Ursus Mechanical Plant in Warsaw, the Head of Political Council. LPR referred to national-democratic ideas: compliance of Polish politics with the interest of the nation, maintaining independence and sovereignty of the state, economic and social development, as well as national solidarity ${ }^{1}$.

The article is an analysis of the evolution of LPR's relevance on the Polish political stage. The term shall be understood as the ability of a political party to influence, in the direct and repetitive manner, the formulation and implementation of the policy of state as the co-governing entity and effective opposition ${ }^{2}$. The aim of the article is to prove the hypothesis that LPR had substantial potential

1 C. Maj, E. Maj, Narodowe ugrupowania polityczne w Polsce: 1989-2001, Lublin 2007, p. $257-265$.

2 A. Antoszewski, Relewancja partii politycznej, [in:] A. Antoszewski, R. Herbut (eds.), Encyklopedia politologii, vol. 3: Partie i systemy partyjne, Kraków 1999, p. 212-213. 
to become an influential national party in Poland, but did not make use of it and from a co-governing group it eventually became a non-parliamentary party with diminishing political influence. The following questions were helpful for that purpose:

1) What was the organizational foundation of LPR?

2) What position did the League have on the Polish political stage?

3) What was the reason for political success and eventual failure of the party?

\section{The initial stage of political activity}

The ambition of LPR was the strive to unite the political parties referring, first and foremost, to national, but also conservative values, which was supposed to be an alternative to the elites ruling Poland that were considered liberal, secular and cosmopolitan. Such a coalition was supposed to gain power in the country and lead to calling to account the leaders of the Peoples' Republic of Poland and the Third Republic of Poland accused of selling out public assets and leading to economic downfall of the state ${ }^{3}$. The first month of the League's existence brought their leaders success: different parties sharing the values akin to the neo-national democracy and lead by recognizable figures from the right side of the political spectrum started to unite around it. Among them were the Polish Agreement (Porozumienie Polskie) of Jan Łopuszański, the National-Catholic Movement of Antoni Macierewicz, the Polish Alliance of Gabriel Janowski and the Movement for Reconstruction of Poland of Jan Olszewski ${ }^{4}$.

The objective of LPR was to gain strong position in the parliament and to become a party in opposition to the politicians from post-communist groups and opposition of the People's Republic period who concluded the Round Table Agreement in April $1989^{5}$. The time remaining to the parliamentary elections in September 2001 was devoted to getting parliamentary mandates. The election programs focused on several main issues; these included: defence of political and economic sovereignty, creating effective administration, economic growth, alleviating the social life standard and creating law based on catholic and national values ${ }^{6}$.

3 C. Maj, E. Maj, Narodowe ugrupowania..., p. 258-260.

4 M. Wójcik, „Ojcowizna” razem z Liga, «Nasz Dziennik» (next: ND), 18 VII 2001, № 166, p. 3.

5 Karta Praw Polaków, «Myśl Polska na Wybory» (next: MPW), 9 IX 2001, № 6, p. II.

6 Ibidem; Polsce - Niepodległość. Polakom - Praca, Chleb, Mieszkanie. Odezwa do Narodu Polskiego, «MPW», 19 VIII 2001, № 3, p. I. 
In the elections of 23.11.2001 the League achieved a success - 1025148 people voted for it, which comprised $7,78 \%$ of all validly cast votes. It exceeded the electoral threshold and the party entered the parliament, introducing 38 candidates and becoming the first national party in the Polish parliament since 1930. Most votes casted for LPR were casted in electoral districts no 23 (Rzeszów) - 67123 and no 19 (Warsaw I) - 52 331, and by percentage in districts no $23-15,78 \%$ and no 15 (Tarnów) - 13,02\%. The lowest number of votes were casted in districts no 40 (Koszalin) - 9161 and 32 (Sosnowiec) - 11111 ; the percentage results were also the lowest there: $3,97 \%$ (no 32 ) and 4,45\% (40) respectively. The most mandates were gained in districts no $23-3$, as well as 6 (Lublin), 13 (Kraków), 19 and 24 (Białystok) -2 in each one (elections in 2001)7. Good election result was the effect of consolidation of national and catholic forces within one group, which limited dissipating votes of the electorate.

LPR was within the parliament the sixth, and the smallest parliamentary group consisting of $36 \mathrm{MPs}$, as two candidates of ROP (the Movement for Reconstruction of Poland) did not affiliate with the League. Kotlinowski became the leader and the presidium included Giertych, Janowski, Łopuszański, Macierewicz, Wrzodak and Anna Sobecka ${ }^{8}$. LPR became an opposition party to the government of Leszek Miller, formed by the coalition of Democratic Left Alliance, Labour United, and Polish People's Party. A small size of the group resulted in small influences on the Parliament institutions. The members did not manage to get a post of vicemarshal, and while allocating posts within the commissions, LPR received the head post in only one of them- the Commission on Communications with Poles Living Abroad, which was succeeded by Giertych, who kept it until the end of the term. Four MPs became deputy-heads of different commissions 9 .

During the 4th term the number of members varied in LPR to eventually amount 19 in September 2005. At the end of 2002 ten MPs left RKN, PP and PdP and in April 2004 eight MPs formed a parliamentary club 'Dom Ojczysty' (the Homeland). The reasons that were provided included, among others, reluctance to the authoritarian way of exercising their power by R. Giertych and Kotlinowski, as well as program differences, including the attitude towards the war in Afghanistan or elections to the European Parliament. LPR was joined by 3 MPs from PSL (Polish People's Party) and one from Self-Defence and Law and Justice ${ }^{10}$.

7 Wybory parlamentarne 2001, http://wybory2001.pkw.gov.pl, (access: 1.10.2018).

8 C. Maj, E. Maj, Narodowe ugrupowania ..., p. 251.

9 Archiwum Danych o Posłach 2001-2005, http://orka.sejm.gov.pl/ArchAll2.nsf/Glowny4kad (access: 1.10.2018).

10 Ibidem; M.D.Z., Eurosceptyczni nomadowie, «Rzeczpospolita» (next: Rz), 10 XII 2002, № 287, p. 4; P.Ś., Ewakuacja z LPR, «Rz» 15 IV 2004, № 89, p. 4. 


\section{Political success}

At the turn of 2002 and 2003 LPR included about 12000 members $^{11}$ and it attempted to reinforce its position in the Polish political system. Their leaders began to strive to gain influence in particular regions and began preparations to municipal elections. The election program declared implementation of a municipal reform that relied on making regional and local authorities serve interests of citizens. The main tasks that municipal authorities had to do at the level of boroughs, counties and voivodeships, such as landscape planning, investments in infrastructure, economy, healthcare, social services and education, simulating the work market and protecting public security were presented ${ }^{12}$.

In the elections of 27.10.2002 the League achieved greater success than a year before, as the level of local voivodeship parliaments 1603081 votes were casted for it on the nationwide scale, which comprised $12,28 \%$ of all the validly casted votes. The League received 92 mandates, which positioned it in the fourth place nationwide. Most votes were casted for LPR in the Masovian Voivodeship (215 103) and Lesser-Poland (175 025), and by percentage - in the Subcarpathian Voivodeship $(22,86 \%)$ and the Lublin Voivodeship (18,36\%). The fewest votes were casted in the Lubusz Voivodeship (36 403) and the Holy Cross Voivodeship (45 052), and by percentage - in the Holy Cross Voivodeship (10\%) and the Pomeranian (10,36\%). The League got mandates in voivodeship parliaments of all voivodeships, the most of which was in Lesser Poland and Sub-Carpathia - 9 in each (in the second province it got the first place) ${ }^{13}$.

Electoral successes did not always translate into gaining influence on regional authorities. In the Sub-Carpathian Voivodeship LPR did not form a majority coalition due to the lack of agreement with the Civic Platform (PO) and the Law and Justice party (PiS). In result the political power was seized by the coalition of SLD - PSL - Self-defence ${ }^{14}$. The League, however, managed to enter the executive boards of Lubusz, Lesser Poland and Masovian voivodeships. Stanisław Gogacz became the first vice-marshal, whereas Jan Chróścikowski became the executive board member; they, however, held their posts for a month (December 2002-January 2003). In May 2005 LPR regained power and its representative, Tomasz Miszczuk, became the board member, holding his post until the end of the term. In the Lesser-Poland Voivodeship Jan Bereza and Wiesław

\footnotetext{
11 M.D. Zdort, Recepta na rozłamy, «Rz» 8 V 2002, № 106, p. 9; S. Chruszcz, Nasze dziesięć tygodni, «Racja Polska» (next: RP), 30 III 2003, № 5, p. 25.

12 Ramowy program Ligi Polskich Rodzin dla wyborów samorządowych, «Sejm Library» (next: SL), № I.074/01.

13 Wybory samorzadowe 2002, http://wybory2002.pkw.gov.pl, (access: 1.10.2018).

14 MAT, Bastion w opozycji, «Rz» 19 XI 2002, № 269, p. 3.
} 
Zimowski were the executive board members for the whole term (November 2002-November 2006). In the Mazovian Voivodeship LPR was also included in authority institutions for the whole term. Vice-marshals were: Wojciech Wierzejski (November 2002-July 2004), Bogusław Kowalski (October 2003-October 2005) and Waldemar Roszkiewicz (October 2005-November 2006), and the executive board members were: Kowalski (November 2002-October 2003), Roszkiewicz (June 2002-October 2005) and Jan Engelgard (October 2005-November 2006). In three voivodeships LPR entered the executive boards in a later period. In the Lower-Silesia Voivodeship the members of authority institutions were ViceMarshal Artut Paprota and Rafał Borutko (August 2004-November 2006); in the Łódź Voivodeship vicemarshal Marek Ratuszniak (March-November 2004), as well as Paweł Chruszcz (March-June 2004) and Jadwiga Beda (June-November 2004), whereas in the Greater Poland Voivodeship vice-marshal Przemysław Piasta (October 2005-November 2006) ${ }^{15}$.

In years 2003-2004 LPR was dealing with the issues of the European Union: preparations to the accession referendum and elections to the European Parliament. In the referendum campaign the League opposed accession, presenting the threats that presence within the EU structures would bring to Poland: loss of sovereignty as well as social and economic downfall of the state ${ }^{16}$. The referendum of $7^{\text {th }}$ and $8^{\text {th }}$ of May 2003 was a success of integration supporters, but almost 4 million people $(22,55 \%)$ voted against the accession, which was considered by LPR as a success ${ }^{17}$. The party board decided to take part in the elections to the EU parliament, claiming that participation in the electoral campaign would be a possibility to show the League's program in media ${ }^{18}$. While preparing to the elections LPR presented the goals that were set: maintaining sovereignty of Poland against subordination to the EU authorities, attempts for appropriate allocation of EU funds, enabling development of the Polish state, creating law on the basis of Christian values, as well as protecting Polish economy against expansion on the side of the developed countries ${ }^{19}$.

The elections of 13.06.2004 brought another success to the League of Polish Families. 969689 voters voted for it, which comprised 15,92\% of validly cast votes and translated into 10 mandates. The League had second place in the elections.

15 Information, which were gained from marshal offices.

16 Program Polski nowoczesnej, «RP» 13-20 IV 2003, № 7-8, p. 9; Wolna Polska poza Unia, «RP» 27 IV-4 V 2003, № 9-10, p. 4.

17 Referendum $2003 \mathrm{roku}$, http://referendum2003.pkw.gov.pl/sww/kraj/indexA.html, (access: 1.10.2018).

18 Stanowisko II Kongresu LPR w sprawie sytuacji politycznej Polski po zaakceptowaniu w referendum przez Naród wejścia Polski do UE, «RP» September 2003, № 28, p. 8.

19 Naszym celem jest obrona tożsamości i suwerenności Polski, «Nowa Myśl Polska» 25 IV 2004, № 17, p. 3. 
Most people voted for it in the electoral districts no 10 (Kraków) - 150091 and no 11 (Katowice) - 92 326, and by percentage in districts no 9 (Rzeszów) - 24\% and no 8 (Lublin) $-23,59 \%$. The lowest support for the League was in district no 2 (Budgoszcz) - 46221 and no 1 (Gdańsk) - 54 608, and by percentage in electoral district no 4 (Warsaw) - 10,53\% and 13 (Gorzów Wielkopolski) - 12,08\%. LPR did not receive mandates in three districts and in other ones it got one mandate in each district ${ }^{20}$. High position of LPR was the effect of low turnover and relatively effective propaganda, threatening the citizens with the dangers on the part of the European Union and presenting a positive alternative to accession.

Electoral success caused that the leaders of the League were announcing victory in the next parliamentary elections ${ }^{21}$. The next electoral campaign in September 2005 was prepared with that thought in mind. Attention was paid to the changes that LPR was about to bring after winning the elections. The aim of the League was to create the Fourth Republic of Poland, a system that would guarantee independence of Poland in internal and international politics and ensure economic and social growth of the state and its citizens. There was a strive to prevent transferring sovereign competences of the Polish state to other entities, to make the institutions of authority and administration more effective, to create the foundations of economic self-sustainability, as well as to adopt financial and tax policy enabling emergence and development of Polish enterprises and alleviating the life standard of people 22 .

The elections of 25.11.2005 indicated, however, diminishing influence of LPR which received 940762 votes $(7,97 \%)$, so over 80 thousand votes fewer than four years ago. This translated into 34 parliamentary posts. The most votes for the League were casted in districts no 23 (Rzeszów) - 52776 and no 6 (Lublin) - 49 044; by percentage - in district 22 (Krosno) - 13,63\% and no $23-13,09 \%$. The League received the fewest votes in district 40 (Koszalin) - 8083, as well as no 34 (Elblagg) - 9289 , and by percentage in districts no $40-4,61 \%$ and 31 (Katowice) - 4,97\%. In 11 districts LPR did not get a single mandate. In 5 districts the League gained 2 mandates: no 6, no 7 (Chełm), no 22, no 23 and no 24 (Białystok) ${ }^{23}$. The result that was worse than expected was due to conflicts within the party and club structures of the fourth term. In the Subcarpathian Voivodeship there was a struggle between the supporters of Wrzodak and R. Giertych ${ }^{24}$. In the Warmian-Masurian Voivodeship the central authorities, without an agreement with the provincial board, compiled their own lists of candidates to the parliament,

20 Wybory do Parlamentu Europejskiego 2004, http://pe2004.pkw.gov.pl, (access: 1.10.2018).

21 R. Giertych, Chcemy wygrać!, «RP» January 2005, № 1, p. 5.

22 Konstytucja IV RP, Warszawa 2005; km, Znamy programy, «RP» August 2005, № 5, p. 31.

23 Wybory parlamentarne 2005, http://wybory2005.pkw.gov.pl, 1.10.2018.

24 J. Matusz, Brudna wojna o bastion, «Rz» 22 II 2005, № 44, p. 4. 
which comprised of the people from outside the voivodeship. This caused the voivodeship board to hand over resignation and dissolve the voivodeship structures of $\mathrm{LPR}^{25}$. The party leaders were accused of promoting Giertych and his followers from the All-Polish Youth, and disregarding the distinguished national activists ${ }^{26}$. This caused the loss of trust to the party on a part of the electorate. In result of the conflict the party authorities purged the opposition members from the party, including MP Wrzodak or MEP Bogdan Wrodak, the Deputy Head of LPR. One MP and three MEPs were also purged from the party ${ }^{27}$.

In the parliament LPR formed a club including $32 \mathrm{MPs}$, becoming, thus, the fifth parliamentary club in size. Giertych was its leader and in the presidium there were, among others, Sobecka, Kotlinowski, Bogusław Kowalski and Janusz Dobrosz ${ }^{28}$. Although LPR included few MPs, the support for the minority government of Kazimierz Marcinkiewicz from PiS caused that its position in the parliament of the $5^{\text {th }}$ term was stronger than four years before. Kotlinowski became Vice-Marshal of the parliament, and four MPs received posts of committee leaders: Dobrosz (Commission on Communications with Poles Living Abroad), Giertych (Commission of Secret Service), Kowalski (Commission of Infrastructure) and Sobecka (Commission on Family and Women Rights). The League also received posts of commission deputies of 8 commissions ${ }^{29}$.

During the fifth term of the parliament the League decreased in number and at the moment of its conclusion in October 2007 it included 29 MPs. It was also caused by another conflict in the structures between central structures, led by Giertych who had been elected a leader in October 2007, and the Deputy Head Kowalski and Sobecka. The followers of Kowalski wanted the League to establish collaboration with PiS and enter the government as a coalition member. For that purpose they initiated talks with the representatives of the ruling party. The followers of Giertych preferred to stay in opposition and critically assess the activity of the ruling politicians so as to co-opt a part of PiS electorate. The conflict resulted in five MPs leaving the party in April 2005; they founded the National Parliamentary Group and established cooperation with PiS (two of them returned to the League after a month) ${ }^{30}$.

25 i.t., Sekta Giertycha, imperium strachu, «Rz» 29 VIII 2005, № 201, p. 4.

26 P. Śmiłowicz, Wrzodak w Domu Ojczystym, «Rz» 8 VIII 2005, № 184, p. 5.

27 ola, Spychaja Wrzodaka na boczny tor, «Rz» 17 X 2005, № 243, p. 4.

28 Nowy Sejm, nowy klub, nowy przewodniczacy, http://www.lpr.pl/pl/2005/09/29/nowy-sejmnowy-klub-nowy-przewodniczacy, 1.10.2018.

29 Archiwum Danych o Posłach 2005-2007, http://orka.sejm.gov.pl/ArchAll2.nsf/ Glowny5kad, (access: 1.10.2018).

30 W. Wybranowski, Czy LPR się kurczy?, «ND» 30 III 2006, № 76, p. 5; M. Goss, Pęknięcie w politycznym tyglu, «ND» 19 IV 2006, № 92, p. 3; M. Wójcik, Tercet zamiast kwartetu, «ND» 28 IV 2006, № 180, p. 3. 
The conflict in LPR forced the party leaders to initiate talks. It turned out that many local leaders supported accession of the League to the government and were not satisfied with Giertych policy, who opposed that. Such situation occurred, among others, in Kuyavian-Pomeranian, Lubusz and Greater Poland voivodeships ${ }^{31}$. Eventually, on the $5^{\text {th }}$ of May 2006 a coalition including PiS, SelfDefence and LPR was formed and the League received two ministries: Giertych became Deputy Prime Minister and the Minister of National Education and Rafał Wiechecki the Minister of Marine Economy ${ }^{32}$. The party also received the posts of deputy ministers in the ministries of economy, regional development and construction, marine economy, as well as in the European Integration Committee and Prime Minister's Office. The League remained in the ruling coalition for 15 months, until 13.08.2007, when Prime Minister Jarosław Kaczyński concluded the coalition and restored the minority government ${ }^{33}$. It was the first time since the government of Tomasz Arciszewski that a national party had representatives in the government of the Republic of Poland.

\section{Political downfall}

The League was preparing for the next municipal elections in the atmosphere of inner-party conflicts. Repressions towards local leaders supporting Kowalski and Sobecka led to the decrease of support for the LPR board on the side of provincial structures, and leaving the party by them. Since August 2006 the councillors abolished LPR clubs in the municipal governments of KuyavianPomeranian, Silesian, West Pomeranian, Opole, Podlaskie, Mazovian and Greater Poland voivodeships, expressing their support for the MPs of the National Parliamentary Club ${ }^{34}$. Despite those difficulties the leaders of LPR attempted to appeal to the pro-family program so as to unite the electorate. Among the goals the following were mentioned: ensuring safety in public places, granting property rights to the owners of council houses, mobilization of municipal governments for implementing pro-development policy, development of local economy, appropriate social and educational policy and effective use of the EU funds ${ }^{35}$.

The elections of 12.11.2006 resulted in the defeat of LPR. At the level of municipal governments the party received 568935 votes, which was over one

\footnotetext{
31 W. Wybranowski, Chca sojuszu, więc rozmawiaja, «ND» 6-7 V 2005, № 105, p. 4.

32 M. Wójcik, Rząd ma większość w parlamencie, «ND» 6-7 V 2006, № 105, p. 1.

33 M. Stawarska, Teraz tylko PiS, «ND» 14-15 VIII 2007, № 189, p. 1.

34 W. Wybranowski, Już nie z Liga, «ND» 16 VIII 2006, № 190, p. 4; idem, Pękaja struktury Ligi, «ND» 2-3 IX 2006, № 205, p. 3.

35 Z troska w przyszłość. W odpowiedzialności za Państwo, «SL» № I.074/02.
} 
million fewer than four years before and amounted 3,95\% of all validly casted votes. Most people voted for the League in Mazovian (104 458) and Lesser Poland (63 662) viovodeships, and by percentage - in Lubusz (6,52\%) and Lesser Poland (6,18\%). The lowest support for LPR was in Opole (9536) and Lubusz (13 962), and by percentage - in Opole (3,36\%) and Silesia (3,47\%). LPR received 11 mandates, which positioned it at the sixth place nationwide. Four mandates were received in Lesser Poland and in Mazovian voivodeships, 2 in Sub-Carpathia and 1 in Lubusz ${ }^{36}$. For several months it was a coalition member in the executive boards of 2 voivodeships. In November 2006 Waldemar Roszkiewicz (Mazovian Voivodeship) and Wojciech Bosak (Lesser Poland) were nominated Vice-Marshalls. Roszkiewicz soon moved to PSL, whereas Bosak was recalled from his post in March 2007. Thus, LPR stopped playing a role in municipal politics ${ }^{37}$.

In September 2007 the parliament shortened its term, forcing the League to prepare to new electoral campaign. At the moment of the term's end the position of LPR in the parliament was strong: it had a vice-marshal, namely Dobrosz who had held this post since November 2006, 3 deputy heads of commissions: Janusz Kołodziej (Commission of Infrastructure), Leszek Murzyn (Commission on Parliamentary Ethics) and Stanisłąw Zadora (Commission on Communications with Poles Living Abroad) and 6 deputy heads ${ }^{38}$. The surveys, however, did not hold out the prospects of getting parliamentary mandates. Therefore the party tried to bind with other parties, so as the increase the electorate: firstly with SelfDefence, creating a structure called the League and Self-Defence ${ }^{39}$, and then with Real Politics Union and the Right Wing of the Republic, creating the coalition called the League of the Right Wing of Poland ${ }^{40}$. Among the main goals the following were being mentioned: reinforcement of Polish sovereignty by rejection of the Treaty of Lisbon and objection towards changing Polish zloty for euro, pro-development tax policy and continuation of the pro-family policy ${ }^{41}$.

The elections of 21.10.2007 ended in a defeat of LPR, for which 209171 people casted their votes, which was over 700 thousand fewer than 2 years before. This comprised $1,3 \%$ of all validly casted votes, which was insufficient to enter the parliament. Most people voted for LPR in electoral districts no 19 (Warsaw I) - 14264 and no 6 (Lublin) - 9602, by percentage in districts no 7 (Chełm) -

36 Wybory samorzadowe 2006, http://wybory2006.pkw.gov.pl/kbw/geoKrajd41d.html?, (access: 1.10.2018).

37 Information, which were gained from marshal offices.

38 Archiwum Danych o Posłach 2005-2007...

39 B. Waszkielewicz, Akrobacje polityczne Leppera i Giertycha, «Rz»18-19 VIII 2007, № 192 , p. 3.

40 A. Kowalski, LPR, PR i UPR razem, «ND» 11 IX 2007, № 212, p. 3.

41 Dziesięć najważniejszych punktów programowych KW LPR, «SL» № IV.2007/03. 
$2,1 \%$ and no $6-1,91 \%$. LPR got the fewest votes in districts no 40 (Koszalin) -2560 and no 2 (Wałbrzych) - 2827, and by percentage in districts no 5 (Toruń) $-0,88 \%$, as well as 31 (Katowice) and 38 (Piła) $-0,97 \% 42$. In result of the defeat Giertych resigned from the post of the Head of the Executive Board, and Sylwester Chruszcz was nominated in his place ${ }^{43}$.

The period after 2007 was marked by downfall of LPR significance on the Polish political stage, which was connected with leaving its structures by other activists. In June 2008 Chruszcz and the Head of the Political Council Dobrosz announced the willingness to form a new structure of national, catholic, conservative and people's character, which ended up in an internal conflict and their resignation from their posts, and then leaving the party together with their followers ${ }^{44}$. Elections to the European Parliament forced the leaders of the League to attempt uniting the groups advocating similar values. An opportunity for that was formation, in February 2009, of the Polish branch of the Libertas party, led by an Irishman Declan Ganley. Libertas, which had branches in all EU countries, referred negatively to Union federalization and limiting sovereignty of the member states. LPR was one of the founders of Libertas Poland and Daniel Pawłowiec became one of the Deputy Heads ${ }^{45}$. The lists of Libertas, apart from the politicians of the League, included members of, among others, Poland Forward ('Naprzód Polsko', the party of Dobrosz), Polish People's Party 'Piast', Christian National Union and the Party of Regions, as well as some of the former activists of $\mathrm{LPR}^{46}$. The elections of 07.06.2019 were a failure of the new organization. It received 83754 votes, which comprised $1,14 \%$ of votes nationwide and was insufficient to gain mandates. Most people voted for Libertas in the electoral districts no 8 (Lublin) - 12207 and 10 (Karków) - 9005, and by percentage - in district $8-3,22 \%$ and 5 (Warsaw II) $-2,17 \%$. The lowest support for Libertas was in district 2 (Bydgoszcz) - 3277 votes and no 1 (Gdańsk) - 3676 votes, and by percentage in districts no 11 (Katowice) $-0,63 \%$ and no 4 (Warsaw I) $-0,73 \%{ }^{47}$.

42 Wybory parlamentarne 2007, http://wybory2007.pkw.gov.pl/, (access: 1.10.2018).

43 K. Losz, Z Sejmu do adwokatury, «ND» 25 X 2007, № 250, p. 2.

44 Nowe otwarcie na prawicy: Liderzy LPR tworza szeroka platforme narodowa, katolicka, konserwatywna $i$ ludowa, http://chruszcz.blog.onet.pl/2008/06/27/nowe-otwarcie-naprawicy-liderzy-lpr-tworza-szeroka-platforme-narodowa-katolicka-konserwatywna-iludowa/, (access: 1.10.2018).

45 A. Wiejak, Ganley werbuje do Libertasu, «ND» 2 II 2009, № 27, p. 2; JAC, Libertas Polska, «ND» 21-22 III 2009, № 68, p. 5.

46 Kandydaci LPR z Libertasu, «SL» № VI.2009/03.

47 Wybory do Parlamentu Europejskiego 2009, http://pe2009.pkw.gov.pl/PUE/PL/WYN/M/ index.htm, (access: 1.10.2018). 
After 2009 participation of LPR in elections was more and more limited. The party provided electoral lists only during municipal elections in 2010 and 2014, in which it failed. During the first election the League registered lists in 11 voivodeships (all without Lower Silesia, Lubusz, Opole, Podlasie and Warmian-Masurian). During elections of 21.09.2010 it received 87545 votes, which on the scale of 11 voivodeships comprised $0,75 \%$ of all validly casted votes and did not enable the party to receive any mandate ${ }^{48}$. Four years later, however, LPR managed to register lists of candidates to municipal governments in 4 voivodeships - Lubusz, Lesser Poland, Pomeranian and Silesia. On 16.11.2014 34054 people voted for the party, which on the scale of those voivodeships comprised $0,89 \%$ of all validly casted votes. The party, similarly like in 2010 , did not gain any mandate ${ }^{49}$. The parliamentary elections of 2011 and 2015, as well as the EU elections in 2014 were not participated by the League. The leaders of the party decided that it did not have chances to achieve success in the elections and they withdrew from participation ${ }^{50}$.

\section{RÉSUMÉ}

The article comprises an analysis of political relevance of the League of Polish Families (LPR) - the only party of the national movement in the Republic of Poland that introduced its representatives to the parliament and was a member of government coalition. Thanks to its presence in legislative and executive institutions it was able to participate directly in the legislative processes, implement its ideological concepts and control the government with regard to its functioning. LPR was a party that had significant potential to become an important political entity of national character. The union of national and national-conservative groups, as well as the program directed to a large part of the society sharing similar values provided the party with electoral success in the first years of its existence. This resulted from the belief of the national electorate that LPR had become an effective representative of their interests in the public sphere- the interests so far not pursued by Polish authorities. LPR was not able to make use of those assets; its failure

48 Wybory samorzadowe 2010, http://wybory2010.pkw.gov.pl/geo/pl/000000.html, (access: 1.10.2018).

49 Wybory samorzadowe 2014, https://samorzad2014.pkw.gov.pl/, (access: 1.10.2018).

50 Ważna decyzja wyborcza Zarządu Głównego LPR, http://www.lpr.pl/pl/2011/08/16/waznadecyzja-wyborcza-zarzadu-glownego-lpr/, 1.10.2018; Stanowisko Rady Politycznej Ligi Polskich Rodzin w sprawie wyborów do Sejmu i Senatu, http://www.lpr.pl/pl/2015/10/09/ stanowisko-rady-politycznej-ligi-polskich-rodzin-w-sprawie-wyborow-do-sejmu-i-senatu/, 1.10.2018; Stanowisko LPR w sprawie wyborów do Parlamentu Europejskiego, http://www. lpr.pl/pl/2014/05/21/stanowisko-lpr-w-sprawie-wyborow-do-parlamentu-europejskiego/, (access: 1.10.2018). 
resulted from ideological and personal disputes between the activists, which contributed to breakdowns, division of the electorate and gradual decrease of influence of the party in the society.

\section{Bibliography}
A. Antoszewski, Relewancja partii politycznej, [in:] A. Antoszewski, R. Herbut (eds.), Encyklopedia politologii, vol. 3: Partie i systemy partyjne, Kraków 1999.
C. Maj, E. Maj, Narodowe ugrupowania polityczne w Polsce: 1989-2001, Lublin 2007. 


\section{A dispute between "the Younger" and "the Older" about the economic model of the national movement between 1928 and 1939 (arguments exchanged in the press) ${ }^{1}$}

KEY WORDS:
the national camp, economy, nationalism, political thought, Christian ethics

\section{Preliminary remarks}

Nationalistic organisations played a prominent role in the political life of the Second Polish Republic. Two political parties - the Popular National Union (1919-1928) and the National Party (1928-1939) - were at the organisational core of National Democracy. The ideological contribution of the NP to the legacy of the political thought of the National Camp, and, more broadly, to the Polish and European political thought, was substantial. The NP's political thought covered a broad spectrum of philosophical, economic, historiosophical, ideological, religious, cultural, paedagogical, political, social and systemic issues. The vision forged by the NP encompassed a multitude of political thought domains, including such key categories as internal security, external security, the economy, the nation, the State, society, the status of national minorities, the attitude to Catholicism, political authority and nationalistic upbringing.

Underlying the political thought of the National Party was a number of ideological, political, social and economic factors associated with the political developments of the 1920s and 1930s, both in Europe and Poland. At the same

1 Niniejszy tekst stanowi realizację projektu sfinansowanego ze środków Narodowego Centrum Nauki, przyznanych na podstawie decyzji numer DEC-2013/09/B/HS5/00016. The publication was financed from the National Science Centre resources granted under Decision No. DEC- 2013/09/B/HS5/00016. 
time, these factors determined the evolution of the NP's political thought. The authoritarian-State model advanced by Piłsudski's supporters was the point of reference. Other factors included:

1) the rise of anti-democratic and anti-parliamentary tendencies in Europe;

2) the rise of totalitarian movements within many European countries;

3) Germany's growing political and military potential;

4) the great economic crisis with its various social repercussions.

The NP's political thought drew heavily on the legacy of the Western European political thought, embracing in particular the tenets of nationalistic streams professed by their leading ideologues. The ideas promulgated within the NP were in accord with the enunciations developed within conservative and Catholic communities. This was especially true of how they perceived the "turning point", i.e. the modernising capitalist civilisation. The "young generation" saw the breakthrough in Europe as a consequence of the illegitimacy of the system of values founded on liberal and democratic ideas. Contrary to expectations, the transformation of the PNU into the NP did not lead to the consolidation of the entire National Democracy. The National Party failed to meet the primary objectives underlying its political thought. Most importantly, the NP failed to establish a nation state. Then again, it successfully spread nationalist ideas.

The establishment of the National Party in 1928 marked the beginning of dissension, secessions from the party, conflicts between generations, and political manoeuvring. As a result of ideological differences, there were internal frictions and changes in affiliations between party members. A clear divide opened up between two ideological factions. In primary sources and the literature on the subject there is a division which reflects the generation gap between "the Old" and "the Young". The Old, represented by the "rebellious" generation, former Popular National Union activists, advocates of parliamentary democracy, included Roman Rybarski, Zygmunt Berezowski, Stanisław Głąbiński, Joachim Bartoszewicz, Władysław Seyda, and Stanisław Rymar. The Young generation was inclined to support the single-party system and introduce a "strong government". Prominent representatives of this group included Tadeusz Bielecki, Jędrzej Giertych, Adam Doboszyński, Kazimierz Kowalski, Jan Matłachowski, Stefan Sacha, Mieczysław Trajdos, and Wojciech Wasiutyński.

The term "Young" covered activists whose road to executive positions in the National Camp went through "Młodzież Wszechpolska - Związek Akademicki" (The All-Polish Youth - Academic Association), an organisation established in March 1922, and since April 1927 also through Ruch Młodych OWP (The Camp of Great Poland, Youth Branch), which was probably where the name came from. However, this distinction between "the Old" and "the Young" was not clear-cut. Indeed, the Old included the supporters of both liberal and 
totalitarian views related to public life, and the Young varied in terms of their extremism ${ }^{2}$.

In the early 1930s, during a time of severe economic crisis in Europe and worldwide, representatives of the National Camp were particularly interested in economic issues. Wojciech Wasiutyński, one of the representatives of the Young, presented the views shared by his generation as follows

The great economic crisis has left its mark on all the people who grew up in the late 1920s and the early 1930s. Young people of the 1930s took it for granted that capitalism would come to an end [...] The question was, what would come after capitalism?"3.

Deliberations on business and economic issues generally focused on ways of overcoming the crisis and mitigating its negative impact on Poland. The economic crisis contributed to the popularisation of a simplified, dichotomous vision of the world, firmly divided between "Us" and "Them". Capitalism was commonly criticised $^{4}$. The intellectual atmosphere of that time provoked anxiety and encouraged people to seek new ways of both economic and spiritual growth. It was believed that the economic order within the State, similarly to its political system, should focus on the universal objectives and interests of the nation ${ }^{5}$.

2 Among the fundamental works concerning the national movement, the following ones are worth noting: J. J. Terej, Idee, mity, realia. Szkice do Dziejów Narodowej Demokracji [Ideas, myths and the reality. An outline of the National Democracy's history], Warsaw 1971; J. J. Terej, Rzeczywistość i polityka. Ze studiów nad dziejami najnowszymi Narodowej Demokracji [Reality vs. politics. Studies on the latest history of National Democracy], Warsaw 1979; R. Wapiński, Narodowa Demokracja 1893-1939. Ze studiów nad dziejami myśli nacjonalistycznej [National Democracy 1893-1939. Studies on the history of nationalist thought], Wrocław 1980; also a cross-sectional work by J. Holzer, Mozaika polityczna Drugiej Rzeczpospolitej [The political mosaic of the Second Republic of Poland], Warsaw 1974. J. Zieliński, Narodowa Demokracja na cenzurowanym [National Democracy comes in for criticism], «Dzieje Najnowsze» (Recent History) 1974, No. 3, p. 58-60; K. Kawalec, Narodowa Demokracja wobec faszyzmu 1922-1939 [National Democracy in the face of fascism in 1922-1939]. Ze studiów nad dziejami myśli politycznej obozu narodowego [Studies on the political thought of the National Camp], Warsaw 1989, p. 10, 11; J. M. Majchrowski, Polska myśl polityczna XIX i XX wieku [Polish political thought in the 19th and 20th centuries], Part III: Nacjonalizm: myśl ,potomstwa obozowego" [Nationalism - the thought of the young generation of the National Camp], Kraków 1993, p. 5-36.

3 W. Wasiutyński, Micewskiego szkice węglem [Micewski’s charcoal drawings], "Polemiki" ("Polemics") Book 5, 1966, p. 16.

4 K. Kawalec, Wizje ustroju państwa w polskiej myśli politycznej lat 1918-1939 [Visions of the national system in Polish political thought between 1918 and 1939], Wrocław 1995, p. $166,170$.

5 J. Ziemski, Ingerencja państwa $w$ życiu gospodarczym [Involvement of the State in economic life], «Myśl Narodowa» No. 35, 13 August 1933, p. 511. 


\section{The idea of "the third path" of economic and social development}

In the 1930s, the idea of "the Third Way" to economic and social development became popular with various political groups, such as the Peasant Movement, the National Camp, Christian Democracy, and the Socialist Camp. The concept of "the Third Way" built on Thomism and Catholic Social Teaching. Representatives of the National Camp appreciated the advantages of this "intermediate way", which rejected both economic collectivism and liberalism. It was believed that a new solution would be developed, without building on communism or capitalism. A shift in the economic thought took place, especially in mid-1930s, when Roman Dmowski's ruminations made people realise the downfall of the previous forms of management ${ }^{6}$. During the meeting of the National Party's Chief Council, Dmowski argued that institutions such as "State and municipal companies" must be got rid of, because they are "an extravagance" 7 . His papers, with pessimistic economic scenarios, were welcomed with approval by the Young representatives of the National Camp. Dmowski evaluated the great economic crisis, wrongly anticipating the supposedly inevitable collapse of developed countries ${ }^{8}$.

The National Party did not have a consistent economic programme. Given the growing ideological divide between the Old and the Young, the discord in relation to the economic programme only broadened the gap. The dispute between the Young and Old generations concerned both their outlook on life and their preferred nation State model. The Young took a simplistic approach to economic issues. The press was the vehicle for the polemics between Adam Doboszyński, a representative of the Young, and Professor Roman Rybarski, a leading national academic and representative of the old political school. The Young, fascinated

6 R. Dmowski, Przewrót [The Coup], Warsaw 1934; W.Ś., Przebudowa ustroju gospodarczego [The redevelopment of the economic system], «Dziennik Kujawski» No. 158, 14 July 1938, p. 1; W. Tomczyk, Rzad, PPS i SN wobec wielkiego kryzysu gospodarczego [The Government, the Polish Socialist Party and the National Party in the face of the economic crisis], «Zeszyty Naukowe WSP Rzeszów Historia» Book 7, 1988, p. 51-166.

7 R. Dmowski, Pisma [Letters], Vol. 10: Od Obozu Wielkiej Polski do Stronnictwa Narodowego (przemówienia, artykuly i rozprawy z lat 1925-1934 [From the Camp of Great Poland to the National Party - speeches, articles and dissertations from 1925-1934], Częstochowa 1939, p. 285; J. Zdzitowiecki, Ku lepszej przyszłości [Towards a better future], Poznań 1934, p. 8.

8 B. Grott, Nacjonalizm i religia: proces zespalania nacjonalizmu z katolicyzmem $w$ jedna catość ideowa w myśli Narodowej Demokracji 1926-1939 [Nationalism and religion - the unification of nationalism and Catholicism into one ideological whole in the thoughts of the National Democracy in 1926-1939], Kraków 1984, p. 82; B. Grott, Dylematy polskiego nacjonalizmu. Powrót do tradycji czy przebudowa narodowego ducha [The dilemmas faced by Polish nationalism. The return to tradition or the remodelling of the national spirit], Warsaw 2014, p. 164-172. 
with the idea of national revolution, which was to transform Poland into an authoritarian Catholic State of the Polish Nation, rejected the democratic-liberal system 9 .

\section{The idea of "new Middle Ages"}

The economic thought of the Young built on the idea of the "New Middle Ages", popular in this environment. Elements of Mediaevalism, were explicitly visible in the concept advocated by Adam Doboszyński, who clearly argued for the management and society models developed in Europe in the Middle Ages. Doboszyński went as far as to argue that the nations which "have not significantly departed from their mediaeval role models over time" found themselves in the best position ${ }^{10}$. Approval for the mediaeval economic order could be found in the views of the Young, who argued "In the Middle Ages, human life was about the creation of superior quality products" 11 . For Doboszyński and other representatives of this generation, it was obvious that the socio-economic system of the time, which built on individualism and liberalism, was obsolete and bound to collapse $^{12}$. Other views were advocated by R. Rybarski, a representative of the Old, who rejected the idea of following mediaeval role models ${ }^{13}$.

For Doboszyński and other representatives of the Young, the economic system of the Middle Ages, characterised by "the unity of capital and work", appeared to be a viable alternative to the free market model of governance used at the time. Doboszyński believed that liberalism contradicted the rules proposed by Christian teaching. He postulated that liberalism be treated as an immoral system. Moreover, he questioned the liberal principle laissez faire, laissez passer (live and let live), arguing

when everyone is free to do anything they please, when no moral rules apply, there is no freedom, and people form groups to oppress their fellow countrymen. ${ }^{14}$

9 Ibidem.

10 A. Doboszyński, Gospodarka narodowa [The national economy], Wrocław 2004, p. 8.

11 Biblioteka Naukowa Polskiej Akademii Umiejętności - Polskiej Akademii Nauk w Krakowie (The Library of the Polish Academy of Learning - the Polish Academy of Sciences in Kraków), Józef Zieliński File, Ref. No. 7820, microfilm 1448, Zadania gospodarcze Młodych Obozu Narodowego, Referat wstepny [The economic objectives of the Young within the National Camp, A preliminary report], code 103.

12 B. Grott, Nacjonalizm i religia... [Nationalism and religion...], p. 96.

13 R. Rybarski, Założenia programu gospodarczego [A description of the economic programme], «Myśl Narodowa» No. 43, 18 October 1936, p. 669-672.

14 A. Doboszyński, Gospodarka narodowa... [The national economy...], p. 9. 
In addition, the socio-economic model followed in the Middle Ages appeared to foster perfect social and economic harmony. The workshop, as the basic workplace in mediaeval towns, whose owner worked alongside his apprentices, who could achieve his status in the future, represented this rule in practice. The rule was challenged in the new economic system which was adopted on a broad scale in late-18th-century Europe. The Young found it imperative for economic relations to conform to moral norms. These concepts built on Catholic teaching, and in particular on the philosophy of St. Thomas Aquinas ${ }^{15}$.

\section{Criticism of capitalism}

In the 1930s, nearly all the ideological/political groups operating at the time, from the Peasant Movement to Christian-Democrats and the National Camp, criticised capitalism ${ }^{16}$. However, the term "capitalism" was understood and construed in different ways. The Young within the National Party also started to derogate the principles underlying the capitalist system. Doboszyński argued that the capitalist system focused on amassing property in the hands of the few. By criticising capitalism, he showed sensitivity to the problems of the poor and the unemployed. He argued that in each society there was a group of people who struggled with poverty. Building on Catholic ethics, he went on to argue that the poor should be provided with support and the unemployed should be provided with job opportunities. In order to reduce unemployment, he advocated that working hours be shortened. He argued that the primary factor responsible for unemployment was the excessive mechanisation of manufacturing. He wrote

the cold calculations which lead to the replacement of people with machines is usually based on the fact that the cost of machine operation, propulsion and depreciation is lower than the pay for workers who could manually perform the same work. ${ }^{17}$

Dobroszyński argued that in order to reduce unemployment it was crucial to 1) reduce the scope of economic development, 2) limit the involvement of women and children in work. Other measures he mentioned for addressing unemployment included the organisation of society into class and corporate forms ${ }^{18}$. The author of

15 B. Grott, Nacjonalizm i religia... [Nationalism and religion...], p. 90.

16 K. Kawalec, Spadkobiercy niepokornych. Dzieje polskiej myśli politycznej 1918-1939 [Heirs of the rebellious. A history of Polish political thought in 1918-1939], WrocławWarsaw-Kraków 2000, p. 213.

17 A. Doboszyński, Gospodarka narodowa... [The national economy...], p. 233.

18 Ibidem, p. 234. 
The national economy" wrote "corporations will connect employers and employees. They will join together to make up higher order organisations which cover similar fields of manufacturing. At the top, this hierarchy will join the authorities of the Nation State. ${ }^{19}$

This was his idea of the "vertical model of the economic organism". At the "horizontal level", Doboszyński advocated that individual corporations encompass classes, which would include people working in different professions, but belonging to the same social stratum.

\section{The State's function in the economic system}

In the economic system advocated by the Young, the State was to play a certain role in the economic life. National institutions were to take care of the projects considered necessary for society as a whole and required considerable resources, e.g., armaments and river engineering. Other sectors of manufacturing were to be left in private hands ${ }^{20}$. It was believed that economic life should be based on private initiatives. The Young from the National Camp argued that the outcomes of work had to be closely connected with private ownership. In their propaganda brochure entitled simply Nasz program gospodarczy (Our Economic Programme), they wrote "Rich individuals - rich nation"21. In addition, national ideologists were convinced that, under some circumstances, the efforts of individuals might not be enough, especially in situations such as river engineering and the construction of railway lines. They believed that in some industries, it was essential for the State to take the initiative ${ }^{22}$.

\section{The "Christian State" system}

They advocated a "Christian System", based on considerable economic freedom. In his paper entitled Gospodarka narodowa (National Economy), Doboszyński distinguished between private ownership and social ownership ${ }^{23}$. He associated the development of technology with the col-

19 Ibidem, p. 142.

20 B. Grott, Nacjonalizm i religia... [Nationalism and religion...], p. 95.

21 BN PAU-PAN, Kraków, Zieliński, Ref. No. 7825, microfilm 1453, Nasz program gospodarczy [Our economic programme], code 228.

22 Ibidem, Popularne wskazania dla działacza narodowego [Popular recommendations for nationalist activists], p. 50.

23 A. Doboszyński, Gospodarka narodowa... [The national economy...], p. 76, 77. 
lapse of the traditional social order, family crisis and the collapse of man. He wrote

It has been repeated to us over and over again that machines operate in a specific way, and humanity must conform to it. The 'technology people' would use the inexorable logic that machines determine the size of manufacturing. Yesterday a turbine had 100 horse power, today it has 100,000 HP, and tomorrow it will have 1,000,000 HP. It has to have 1,000,000. Once again, machines will eradicate thousands of people, create thousands of urban pariahs, destroy thousands of independent workshops, causing thousands of families and independent lives to be shattered. But it has to have 1,000,000 HP. The day after tomorrow, it will be 100,000,000 HP, and each nation will have one machine that will manufacture and distribute everything. ${ }^{24}$

Economic issues were believed to be closely connected with the presence of Jews in Poland ${ }^{25}$. Therefore, economic growth was thought to be conditional on removing Jews from trade and craftsmanship. It was presumed that when Jews were removed from the economy, there would be no unemployment. Economic issues were believed to be connected with the presence of Jews in Poland ${ }^{26}$. The economic activities by the Jewish minority were considered a threat to the development of the Polish manufacturing. The nationalisation of the economy was hampered by the large number of Jews, who dominated trade, industry and services. The National Democratic Party accused them of hostility towards Poland and efforts to undermine the financial well-being of the Polish nation ${ }^{27}$. As argued by one journalist

small manufacturing has been controlled by Jews. As many as 56\% of workshops are controlled by Jews. [...] In Warsaw, major wholesalers sell gloves produced by Jewish manufacturers. At rural fairs, you can only buy a hat from a Jew. In upcountry towns, corset-making and hat-making are almost exclusively done by Jews. The unemployed, poor women, should receive professional training, and the whole current demand should be directed their way - there is enough revenue for many. ${ }^{28}$

There were demands to give priority in job opportunities to Poles "over foreigners and other parasitic migrants" 29 . "Głos Lubelski", a daily newspaper, in its article

24 Ibidem, p. 83, 84.

25 Ibidem, p. 78-82.

26 Ibidem.

27 T. Gluziński, Bezrobocie jako sprawa cywilizacji i ustroju [Unemployment as a developmental and systemic issue], «Myśl Narodowa» ("National Thought") No. 17, 22 April 1934, p. 243.

28 M. Sucheni-Rutkowska, Praca zarobkowa kobiet [Gainful work for women], ibidem, No. 9, 25 February 1934, p. 116.

29 T. Gluziński, Bezrobocie... [Unemployment...], p. 243-245. 
with the distinctive title Trzeba pamiętać o większości polskiej [Keep in mind the Polish majority], reminded readers about "the overriding need to strengthen the Polish economic potential in the city" 30 .

\section{Anti-industrialism as a means of overcoming the economic crisis}

As new ways were being sought to create economic growth, anti-industrialisation was establishing itself as one of the ways to overcome the crisis. The assessment of the economic reality of the time led to the conclusion that it was the industrialised countries that were particularly severely affected by the crisis. Capitalism was expected to be overthrown permanently and replaced by a new economic order, based on autarky. R. Dmowski argued that the greatest danger for the European civilisation was the extremely rapid technological development, which was "not followed by moral and political growth" 31 . Based on this assumption, the main objective was to prepare Poland for those "new times". This was to be achieved through 1. a comprehensive development of the native manufacturing capacity; and 2. a reduction in the influx of foreign capital.

Anti-industrialisation, as advocated by the Young, was a crucial component of the presented concepts. The criticism of industrialisation was combined with the opposition to "the support for development". A. Doboszyński was convinced that industrialisation was to blame for the crisis in developed countries. He postulated that the conviction about the constant need for technological advancement had to be eradicated from the human mentality. Doboszyński acknowledged the advantages of manually crafted products, which he believed to be the opposite of "machine-made rubbish".

As the opponent of industrialisation, A. Doboszyński had a peculiar view of the role of manufacturing machines in the national system. He viewed their role as purely ancillary. He argued

in the national system, machines will not be at the core of manufacturing; quite the contrary, they will be auxiliary measure in small and medium-sized manufacturing plants, a tool for the enfranchisement of the masses, if you will. ${ }^{32}$

30 Trzeba pamiętać o większości polskiej [Keep in mind the Polish majority], «Głos Lubelski» No. 171, 25 June 1929, p. 2.

31 R. Dmowski, Świat powojenny i Polska [The post-War world and Poland], Warsaw 1931, p. 19.

32 Adam Doboszyński o ustroju Polski [Adam Doboszyński about the Polish system], introduction, selection and analysis B. Grott, Warsaw 1996, p. 50, 51. 
He went on to claim

a machine must be used by a shoemaker for the manufacturing of cheap shoes, not by a shoe factory for making shoe makers go bankrupt. When their role is restricted in such a way, machines will become a very useful tool. ${ }^{33}$

This approach to technological advancements and innovations met with strong objections from R. Rybarski, who explained

some people have a romantic view of poverty. They approach contemporary technology, and the speed at which other nations advance, with contempt. They think we can organise our country the way we like, that we can turn our backs on modern industrialisation, and peacefully cultivate Polish poverty, which saves us from materialism in life and from the nerve-racking contemporary progress. ${ }^{34}$

Zygmunt Raczkowski, a journalist, in his article with the distinctive title Od teo do technokracji [From theocracy to technocracy], published in "Myśl Narodowa" ("National Thought") in 1935, asked

However, is the fact that the majority of people are involved in the production of redundant things really to be considered as progress? 35

Instead of technological advancement, Raczkowski supported the development of the relationship between man and nature. He considered modern technological inventions unnecessary. He wrote

[...] rail-roads, steamboats, balloons and airplanes, telegraphs and radio, cinemas and record players. These are all valuable things, but generally not indispensable. ${ }^{36}$

Instead of "mindless" technological advancement, the journalist recommended that people cultivate spiritual values. He warned that technological advancement had brought a spiritual crisis on people. Raczkowski bitterly wrote "we moved from theocracy [...] to technocracy" 37 . He went on to recommend careful thought about the direction in which humanity strived. Marian Sarzyński, another journalist writing for "Myśl Narodowa", expressed similar views on the subject, warning

33 Ibidem, p. 51.

34 R. Rybarski, Założenia programu gospodarczego [A description of the economic programme], «Myśl Narodowa» No. 43, 18 October 1936, p. 671.

35 Z. Raczkowski, Od teo do technokracji (From theocracy to technocracy), ibidem, No. 1, 6 January 1935, p. 2.

36 Ibidem, p. 1.

37 Ibidem, p. 2. 
we are living in times when money is more important than man [...] In addition to this supremacy of capital over people, another major defect of the contemporary financial system is the instability of money. ${ }^{38}$

As new ways were being sought for overcoming the economic crisis, antiindustrialisation appeared to be an effective solution. The assessment of the economic reality of the time led to the conclusion that it was the industrialised countries that were particularly severely affected by the crisis. The Young reiterated Dmowski's arguments that economic underdevelopment could be constructive, making it possible for Poland to overcome the crisis. Capitalism was expected to be overthrown permanently and replaced by a new economic order, based on autarky. A. Doboszyński focused a lot on criticising liberalism. He recognised the opposition between the ideas advocated by liberalism and the values proposed by Christian thought. He regarded systems based on the liberal order as immoral and corrupt, explaining

when everyone is free to do anything they please, when no moral rules apply, there is no freedom, and people form groups to oppress their fellow countrymen. Whoever is stronger seizes as much as possible and subjugates their immediate environment; demands that the fruit of other people's labour be given to them, deprives them of freedom, and monopolises power and tangible goods. 39

This view was echoed by Jan Dobraczyński, who emphasised the unethical character of liberalism.

The purpose of liberalism was to lift all the restrictions which could affect people. In other words, to free people of all the responsibility for the motives for their actions. ${ }^{40}$

While R. Dmowski and A. Doboszyński expressed their conviction that capitalism was bound to collapse shortly, R. Rybarski advocated a different view, expecting no downfall of the system based on the free market. Rybarski did not build on the principles of the social teaching of the Catholic Church. The Young in the National Camp accused R. Rybarski of relativism and of divesting himself of absolute values ${ }^{41}$.

38 M. Sarzyński, Chory pieniądz i chory kredyt (Ill money and ill loans), «Myśl Narodowa» No. 45, 3 November 1935, p. 687.

39 Adam Doboszyński o ustroju... [Adam Doboszyński about the Polish system], p. 31.

40 J. Dobraczyński, Najaktualniejsze hasła [Recent buzzwords], «Myśl Narodowa» No. 5, 30 January 1938, p. 66.

41 K. Rogaczewska, Myśl ekonomiczna Narodowej Demokracji w kontekście konfliktu liberalizmu i socjalizmu [The economic thought of the National Democracy in the context of the conflict between liberalism and socialism] [in:] T. Sikorski, A. Wątor (eds.), Narodowa 
The views advocated by Doboszyński were also challenged by Stanisław Grabski, a representative of the Old, who wrote

great scientific and artistic works are not created in cramped, low cottages with thatched roofs, in front of a bowl of potatoes sloppily topped with fat. ${ }^{42}$

He went on to deplore the fact that, in Poland, such terms as nouveau riche or careerist were still deprecatory in nature ${ }^{43}$.

\section{Concluding remarks}

R. Rybarski considered the major economic objective to be the need for increased capitalisation and an increase in the national wealth. He deplored the economic condition of Poland, writing

Poland has been a poor country since at least the mid-17th century. After the partitions, some districts in Poland were relatively well-off, but it was because of special reasons, and was largely connected with the infiltration of foreign capital into Poland. 44

He acknowledged small manufacturing workshops, but not as primary manufacturers, as advocated by the Young, but as a necessity, due to the difficult situation in the country, where the available workforce exceeded the available capital and machines. Moreover, Rybarski advocated the existence of heavy industry. He rejected the claim about the collapse of capitalism.

In the days of the economic crisis, Polish national thought sought solutions to economic problems. The purpose of such efforts was to develop a national economy system. The people were opposed the advancement of industrialisation. It was considered necessary to build on small farms and workshops as the most appropriate and offering the greatest financial benefits for the growth of the nation. The economic thought of the Young in the National Camp provided for the revision of both liberal and socialist orders. Capitalism was thought to "have become outdated", and simple forms of management were to be considered promising. Building on Christian teaching, it was believed that economic and social orders were not to be created at the cost of human suffering. Economic relations were to be governed by social justice. It was argued that economic life

Demokracja XIX-XXI wiek, Koncepcje - ludzie - działalność (National Democracy in the 19th to 21st centuries, Concepts-People-Activities), Szczecin 2008, p. 95.

42 S. Grabski, Ku lepszej Polsce (Towards a better Poland), Warsaw 1938, p. 20.

43 Ibidem, p. 20.

44 R. Rybarski, Nasze ubóstwo (Our poverty), «Myśl Narodowa» No. 44, 25 October 1936, p. 687. 
was to be based on ethics and Christian culture. This was because the solutions to economic problems, as proposed by the Young in the National Camp, were founded on spiritual, moral and ethical, rather than financial, values.

As an opposition party in the years 1928-1939, the NP did not have a real influence over the political reality. The party was not in a position to rule or co-rule Poland. So, the NP's leaders could not fulfil their ambitions. Given that, seemingly, the NP's ideologues were mentally and intellectually capable of rising to and exercising power in Poland, frustration must have been rampant among the "young generation". For the NP, as an oppositional organisation, the issue of the means by which they could rise to power was as relevant as ever. The party became divided over this issue. The "old generation" considered Piłsudski's party stable and strong. At the same time, they expressed the view that the NP as a political organism was too weak organisation-wise and ill-prepared to engage in radical action. Conversely, the "young generation", whose thinking was largely pragmatic, believed that the ruling party was weak, so the National Camp should take advantage of the mounting social, economic and political problems to seize power.

\section{RÉSUMÉ}

In times of economic crisis Polish national thought was focussed on searching for solutions to economic problems. Its objective was to create a national economic system. In pursuit of a new "third path" for economic development, the young generation of the national camp was distinguished by the formulation of highly-original solutions. It opposed the development of industrialisation. It was thought to be essential to base the system on the model of the small farm and workshop as most appropriate and indicative of the highest financial profits in the development of the nation. The economic thought of 'youth' aimed at revising both the liberal and socialist order. It claimed that capitalism had had its day, whereas simple forms of management should be judged as promising. In drawing on Christian thought it was considered that that economic and social order could not be built on the pain of the people. Economic relations were supposed to be regulated in accordance with the principles of social justice. It was argued that economic life should be based on Christian ethics and culture. Economic issues presented by the 'youth' of the national camp were not based on material values, but spiritual, moral and ethical. 


\section{Bibliography}

R. Dmowski, Przewrót, Warsaw 1934.

R. Dmowski, Świat powojenny i Polska, Warsaw 1931.

A. Doboszyński, Gospodarka narodowa, Wrocław 2004.

S. Grabski, Ku lepszej Polsce, Warsaw 1938.

B. Grott, Dylematy polskiego nacjonalizmu. Powrót do tradycji czy przebudowa narodowego ducha, Warsaw 2014.

B. Grott, Nacjonalizm i religia: proces zespalania nacjonalizmu z katolicyzmem w jedna całość ideowa w myśli Narodowej Demokracji 1926-1939, Kraków 1984.

J. Holzer, Mozaika polityczna Drugiej Rzeczpospolitej, Warsaw 1974.

K. Kawalec, Spadkobiercy niepokornych. Dzieje polskiej myśli politycznej 1918-1939, Wrocław-Warsaw-Kraków 2000.

K. Kawalec, Wizje ustroju państwa w polskiej myśli politycznej lat 1918-1939, Wrocław 1995.

J. M. Majchrowski, Polska myśl polityczna XIX i XX wieku, Part III: Nacjonalizm: myśl „potomstwa obozowego”, Kraków 1993.

J. J. Terej, Idee, mity, realia. Szkice do Dziejów Narodowej Demokracji, Warsaw 1971.

J. J. Terej, Rzeczywistość i polityka. Ze studiów nad dziejami najnowszymi Narodowej Demokracji, Warsaw 1979.

R. Wapiński, Narodowa Demokracja 1893-1939. Ze studiów nad dziejami myśli nacjonalistycznej, Wrocław 1980.

J. Zieliński, Narodowa Demokracja na cenzurowanym, «Dzieje Najnowsze» 1974, No. 3. 


\section{НУРСУЛТАН АБИШЕВИЧ НАЗАРБАЕВ}

\section{Эра независимости}

Астана 2017, 508 c.

\section{(Альберт Садовничий)}

ORCID: 0000-0002-1570-7469

КЛЮЧЕВЫЕ СЛОВА: казахстанская модель, модернизация, суверенность, механизмы принятия решений, особенности, принщииь

В настоящее время в мировой политике очевидно проведение самыми крупными и влиятельными игроками политической линии экспансии, что является вполне естественным, прагматичным желанием сохранить роль, позицию в условиях жесткой конкуренции. Учитывая это, молодые государства СНГ с возрастающей прогрессией в режиме non-stop нуждаются в проведении последовательной, интегральной политики на укрепление суверенитета, своего запаса прочности. Именно отсутствие системного подхода в построении независимого государства, отсутствие сильного законодательства, направленного на выработку эффективной государственной системы, отсутствие целеполагания последовательного отстаивания интересов своего государства привело к появлению ряда политических явлений на пост- советском пространстве, в которых одной из сторон удается оказывать системное вмешательство, подрыв независимого политического курса (вопросы Донбасса, Крыма, Приднестровья, Абхазии и Южной Осетии, Нагорного Карабаха и другие). Очевидно, что основной предпосылкой является слабость внутренней политики пострадавших государств, а основным средством, используемым в подобный ситуациях, активное внедрение известного принципа “разделяй и властвуй”, который имеет успешные тактические политические результаты. В то же время при своевременной активации выработки пострадавшим государством комплексного, аргументированного курса на суверенитет, как показывает исторический опыт (распад Российской Империи, СССР, Британской Империи, Римской Импе- 
рии), в стратегической перспективе данный принцип теряет общественную базу и тем самым слабые государства укрепляют или возрождают свою независимость. Только целостный, конструктивный подход во всех сферах государственной жизни, осознание необходимости учета как позитивных, так и возможных негативных явлений в экономической, политической, культурной сферах с целью их предупреждения является важнейшим фактором укрепления суверенитета государства. Таким образом, именно то государство, которое кумулятивно укрепит социальнополитические, экономические, военные предпосылки, сможет практически реализовать независимый статус с дружественными партнерскими отношениями со всеми участниками глобального политического процесса в различных геополитических условиях.

Особый интерес в этом плане приобретает, отмечаемый многими, позитивный опыт построения независимого Казахстана - крупного государства, которое, несмотря на свое прошлое положение, в тяжелых экономических, национальных, военных обстоятельствах смогло сформировать альтернативный путь для построения независимости и позитивного баланса в социальнополитической жизни, предупредив самые негативные сценарии. Именно в раскрытие уникальности казахстанского пути развития особым образом вписывается книга Н. А. Назарбаева "Эра независимости”, в которой Президент Казахстана обосновывает закономерность, механизмы принятия своих решений, место Казахстана в мировой экономике, геополитике.

На примере описания особенностей развития разных этапов государственного строительства, исходя из личных наблюдений, Н. А. Назарбаев в рецензированной книге показывает собственную "казахстанскую модель” развития государственности. Начиная с эпиграфа, в котором автор провозглашает то, что она “...посвящена моему народу" [c. 3], он привлекает читателя к размышлению о том, насколько ценным является взаимосвязь руководства страны с гражданами, единство общества при прохождении столь трудного, созидательного пути зарождения нового государства. Книга склоняет к рефлексии насколько содержательно формулируются цели государства, описывается административный опыт, который можно применять как модель сохранения устойчивого, сильного государства, сохраняющего межнациональное, религиозное, политическое единство при интенсивных и глубинных экономических преобразованиях. Таким образом, автор постарался в данной книге сформулировать основные своего рода идеологические постулаты через осмысление новейшей истории развития Казахстана. В то же время, книга фокусируется не только на истории, а на безальтернативности устремленности в будущее, постоянной динамике, на том, что сохраниться удастся только государству, которое будет представлять собой “... сообщество свободных, прогрессивных граждан” [с. 507].

Примечательно, что автор книги структурировал ее как своего рода 
летопись нескольких модернизаций Казахстана в рамках проведения последовательной политики на укрепление суверенитета.

Начало модернизаций описывается как самый трудный переломный момент как в социальноэкономическом, так и политическом плане. После распада СССР возникла новая геополитическая ситуация, в рамках которой необходимо было заложить основы государственной конструкции. Уникально, что Н. А. Назарбаев очень подробно описывает процесс легитимации власти, с одной стороны, и процесс становления единоначалия, института крепкой президентской власти, который в новых реалиях имел неоднозначную оценку, с учетом тотального разрушения экономической базы. В рецензированной книге указывается также на особый путь разработки рыночной модели экономики в условиях кризиса и дефицита, направленный на создании национального предпринимательства. На практике государство в лице президента административными методами создало новый класс первых предпринимателей, наиболее талантливых, патриотически настроенных молодых людей, предоставляя преференции для их саморазвития. Несмотря на специфичность представления ситуации, односторонность оценок предпринятых решений, каждое из них очень планомерно описано, как и делается в подобного рода работах, то есть административные, законотворческие, судебные позиции, также, как и ключевые с политологической точки зрения понятия представляются как конвергентная информация о ди- намическом процессе государственных реформ. Это значительным образом, с субъективной точки зрения рецензента, с одной стороны, обогатило текст, с другой стороны, сделало его компактным и легко воспринимаемым.

Раскрытие темы безопасности государства осуществляется во второй части книги (вторая модернизация). В этом контексте внимание фокусируется на анализе формирование собственных силовых структур. В тексте автор отходит от описания деталей, однако отмечает важность решения проблемы Вооружённых Сил Казахстана, справедливо раскрывая ее через объяснение выработки внешнеполитического курса. Следует подчеркнуть умелость раскрытие темы безопасности и внешней политики в едином ракурсе, что позволяет познать большинство принятых решений, их специфику, прагматизм. Аргументировано, достаточно откровенно изложив сложности того, что на территории Казахстана находилась опасная концентрации ядерного оружия, военных полигонов, которые не были подчинены новому государству, автор стремиться привлечь внимание, что данный текст имеет важную исследовательскую ценность и написан со знанием темы. Президент проводит самоанализ многополярности своей политики и активного участия в совершенно разнообразных региональных организациях по безопасности, диверсификации двусторонних отношений с государствами. Можно сделать вывод о том, что сбалансированной сотрудничество с учетом интересов всех крупнейших игроков региона (в первую очередь России 
и Китая) имеет особую политическую значимость для Казахстана, который искусно ее использует. Отступая от унификации внешней политики, Президент привлекает внимание в книге на то, что именно такая своего рода политика баланса сил создает гарантированную базу относительного суверенитета.

Интерес представляет описание личных взаимоотношении с мировыми лидерами, что доказывает особое влияние дружественных межличностных отношении лидеров на отношения между государствами. Следует отметить, что международная линия прослеживается через всю книгу, тем самым подчеркивая желание выделить все более возрастающую роль Казахстана как регионального игрока (это и описание Евразийской экономической инициативы, ШОС, избрание Казахстана непостоянным членов Совета Безопасности ООН в 2017 году и другие).

Особым образом в работе выступает нацеленность Н. А. Назарбаева на развитие культурной сферы, сохранении единого, но многонационального общества с пропорциональной представленностью в Ассамблеи народов. Так же, как и в других вопросах Президент описывает личностный подход к данной особенности страны, постоянно акцентируя, что это и является наиболее созидательным фактором для формирования сильного государства в глобализирующимся мире. С точки зрения мотивов проявляется нацеленность книги подчеркнуть оригинальность в решении национального вопроса.

Представленное подробное описание стадии строительства новой столицы - Астаны, как символа нового государства, доказывает взаимосвязь, симбиоз между развитием материального благополучия и духовного. Тем самым показано, что в рамках государственного строительства очень важную роль играет не только материальный интерес, но и духовная сторона. Хотя автор постоянно подчеркивает приоритетность развития экономики как первостепенной задачи, очевидна обращенность книги на будущее духовное обогащение граждан Казахстана. Н. А. Назарбаев доказывает, что через реализацию столь масштабных, в первую очередь, экономических проектов удается особым образом возродить и развивать государственное мышление граждан, они становятся драйверами идеологической жизни страны. Именно в данном контексте привлекает внимание описание разработки комплексных планов, стратегии развития государства (Стратегия "Казахстан-2030”, Казахстан- 2050”, “Мәдени мұра", Программа "Болашак” и так далее), когда государство вербально обозначает цели, задачи развития, представляемые всему народу страны для всеобщего целенаправленного стремления к процветанию и согласию ради успеха.

Выделяется детальный уровень описание всех основных социальноэкономических, внешнеполитических событий, позволяющий каждому читателю сделать аксиологический анализ неординарности государственного строительства. Собранные в одну книгу факты позволяют познать большинство принятых в Казахстане решений, понять их неповторимость и разнообразие. 
В то же время насколько детально описываются решения в определенных сферах, настолько и кратко затрагиваются вопросы демократических преобразований. В значительной степени лишь в конце книги Президент освещает вопрос открытости политической системы Казахстана. В данном аспекте, необходимо определить, что именно вопрос стабильности политической системы, автономности ее работы является необходимым результатом государственных реформ. Н. А. Назарбаев обозначает два принципа «эволюция, а не революция», «сначала - экономика, потом - политика», тем самым подавая политические реформы лишь в исключительном, узком варианте. Книга фиксирует политические преобразования, в основном, в ракурсе укрепления роли Президента. Представленное автором описание процесса демократизации показывает, что она имеет разнородную природу, а именно процедурные, функциональные особенности, опору на традиционные особенности. Анализ Н. А. Назарбаевым модели постепенной демократизации и его понимание сути данного процесса обозначает ее второстепенность. Прослеживается мотив на снятие ряда политических проблем с повестки дня, создается ложный эффект отсутствия запроса у общества на независимость СМИ, оценки происходящих событий, представляя ее лишь в виде перечисления все более расширяющихся государственных либо подконтрольных государству медиа-холдингов. В данном контексте постоянно обращается внимание на национальную специ- фику общества, что является достаточно спорным вопросом при бесспорных успехах построения свободных азиатских обществ (Южная Корея, Япония). Таким образом, анализ книги указывает на нарушение систематичности процесса демократизации в Казахстане.

Однако, учитывая то, что как в названии книги, так и в определении предмета книги, упор делается не столько на процесс демократических изменений казахстанского общества, а на широкий процесс становления нового государства, даже краткое обращение к вопросу свободы общества не уменьшает познавательную важность работы. Кроме этого, Елбасы Казахстана в конце книги обозначает прямую зависимость гибкости политической системы, разделении властей и ее устойчивостью, а, следовательно, устойчивостью независимости страны, и дает в книге нацеленность в будущем продолжить политические реформы и создании строгих конституционных отношений между властями и обществом.

Резюмируя, следует отметить, что своеобразная летопись успешного опыта казахстанского пути развития суверенного государства, в форме которой изложена рецензированная книга определено является своего рода содержательным пособием по целостному, конструктивному построению суверенной государственности в сложных геополитических условиях. Важно, что в ней описан практический опыт нового успешного независимого государства, построившего партнерские отношения со всеми участниками глобального 
политического процесса. Без сомнения изучения демократических особенностей процесса становления государства должны быть продолжены. В этом контексте исследовательскую значимость представляют более детальные обращения к конституционным реформам и созданию правовых отношений между властями и обществом, которые не были широко освещены в данной книге. Результатом синтеза таких многоаспектных, сравнительных исследованием внутриполитической ситуации с уже представленной в книге социально-экономической, внешнеполитической моделью стала бы целостная монография по успешному государственному строительству в странах СНГ с точки зрения первого лица государства. Книга “Эра независимости" является уникальным шагом в данном направлении.

С точки зрении практической значимости ее можно посоветовать тем, кто занимается теоретическими политологическими исследованиями, также, как и всем, осуществляющим на практике административную, политическую деятельность.
Albert Sadovnichy

BOOK REVIEW

\section{НУРСУЛТАН АБИШЕВИЧ НАЗАРБАЕВ, THE ERA OF INDEPENDENCE}

The book provides an analysis of the sovereignty building in Kazakhstan since the declaring of the independence. It deals with the unique construction stages of the Kazakh model in the difficult economic, international, military conditions of the CIS' first decades. In this context President N. Nazarbayev justifies the integrated approach in politics, decision-making mechanisms, the place of Kazakhstan in global economy, in geopolitical games. This work integrates the description of the country's strategic planning and describes the state-building experience. By the reflection of this type the author shows the essence of coherent political line to stronger the role of the the country and its relative independent status.

KEY WORDS: Kazakh model, modernization, sovereignty, decision-making mechanisms, features, principles 


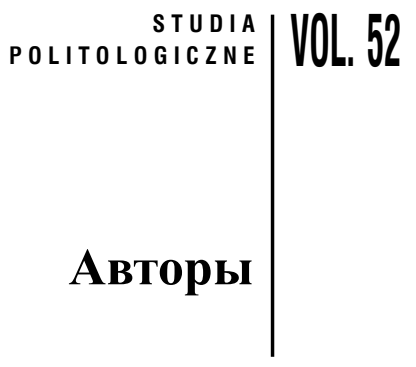

Мереке Габдуалиев, кандидат юридических наук, профессор Российской Академии Естествознания, директор Института развития конституционализма и демократии, Казахстан.

Андрей Валерьевич Гавриков, аспирант института социологии НАН Беларусь, Республика Беларусь.

Виталий Викторович Гончаров, кандидат юридических наук, исполнительный директор Юридическая консалтинговая корпорация «Ассоциация независимых правозащитников», Российская Федерация.

Яцек Залесны, доктор юридических наук, Институт политических наук Варшавского университета, Польша.

Наталья Михайловна Кондратович, кандидат юридических наук, доцент кафедры конституционного права юридического факультета Белорусского государственного университета, Республика Беларусь.

Оксана Владимировна Кукуруз, кандидат политических наук, старший научный сотрудник отдела правовых проблем политологии Института государства и права им. В. М. Корецкого НАН Украины, Украина.

Татьяна Станиславовна Масловская, кандидат юридических наук, доцент кафедры конституционного права юридического факультета Белорусского государственного университета, Республика Беларусь.

Аскар Мирсаидов, начальник юридического управления Министерства внешней торговли Республики Узбекистан.

Омон Закирович Мухамеджанов, доктор юридических наук, профессор Ташкентского государственного юридического университета, Республика Узбекистан.

Михаил Иванович Пастухов, доктор юридических наук, профессор, заслуженный юрист Республики Беларусь, Белорусский институт правоведения, Республика Беларусь.

Альберт Садовничий, магистр Лингвистического университета в Минске, Республика Беларусь.

Шахзод Алихонович Сайдуллаев, кандидат юридических наук, доцент, заведующий кафедрой Ташкентского государственного юридического университета, Узбекистан. 
Алла Соколова, кандидат юридических наук, доцент, профессор-эмеритус. С 1994 до 2004 года работала в Европейском гуманитарном университете в Минске (Беларусь), с 2005 по настоящее время - Академический департамент социальных наук Европейского гуманитарного университета (Вильнюс, Литва). Занимаемые позиции: декан факультета права ЕГУ (1994-2009), декан магистерской школы ЕГУ (2009-2013).

Станислав Суловски, профессор, декан Факультета политических наук и международных исследований Варшавского университета, Польша.

Александр Игоревич Черкасов, кандидат юридических наук, доцент, ведущий научный сотрудник сектора сравнительного права и прав человека Института государства и права РАН, Российская Федерация.

Вениамин Евгеньевич Чиркин, доктор юридических наук, профессор, главный научный сотрудник Института государства и права Российской Академии наук; Заслуженный деятель науки РФ, Заслуженный юрист РФ, Российская Федерация.

Aneta Dawidowicz, doctor of political science, lecturer at the Institute of Political Thought at the Department of Political Sciences at Maria Curie-Skłodowska University in Lublin, Poland.

Tomasz Koziello, doctor of political science, Institute of Political Sciences, University of Rzeszów, Poland.

Anahit Manasyan, candidate of law, Vice-Rector of the Academy of Justice of the Republic of Armenia for Scientific Affairs, associate professor at the Chair of Constitutional Law of Yerevan State University, Armenia.

Dobrochna Minich, candidate of law and master in political science. Assistant professor - Department of Roman Law, Logic and Theory and History of Law, Faculty of Law and Administration Lazarski University, Poland. 


\section{STUDIA POLITOLOGICZNE (wskazówki dla Autorów)}

Forma przekazania tekstu: e-mailem, w edytorze Word (na adres sekretarza redakcji: zalesnyjacek@gmail.com).

Do tekstu dołącza się oświadczenie o oryginalności pracy oraz o tym, że aktualnie nie uczestniczy ona w innym postępowaniu wydawniczym.

\section{Redakcja teks t u \\ Układ analizy:}

Autor

Numer ORCID

Tytułu analizy w języku polskim

Abstrakt: w języku polskim do 600 znaków

Kluczowe słowa: $5 \mathrm{w}$ języku polskim

Struktura analizy:

Wprowadzenie: uzasadnienie wyboru tematu i jego nowatorskość, cele analizy, hipotezy

i tezy badawcze, zastosowane metody badawcze

- analiza

- konkluzje (wnioski)

Streszczenie w języku polskim

Tytułu analizy w języku angielskim

Abstrakt: w języku angielskim do 600 znaków

Kluczowe słowa: $5 \mathrm{w}$ języku angielskim.

Bibliografia

Nota o Autorze (w tym: nazwa instytucji, w której jest zatrudniony, tytuł naukowy, stopień naukowy, adres e-mailowy).

W pracy stosuje się śródtytuły

Czcionka: Times New Roman, 13.

Akapit: wyrównanie do prawej i lewej, wcięcie: 1,25 cm pierwszy wiersz, 1,5 odstępu między wierszami.

Przypisy polskie: na dole strony, numeracja ciągła, czcionka 10, według wzoru:

1 S. Huntington, Trzecia fala demokratyzacji, Warszawa 1995, s. 206.

1 Tamże, s. 27.

1 M. Cichosz, Transformacja demokratyczna - przyczyny, przebieg i efekty procesu, [w:] A. Antoszewski (red.), Systemy polityczne Europy Środkowo-Wschodniej, Wrocław 2006, s. 52.

1 S. Huntington, Trzecia fala..., s. 176.

1 T. Kowalski, Formy i przesłanki obecności kapitału zagranicznego w mediach drukowanych, „Zeszyty Prasoznawcze” 1998, nr 1-2, s. 37.

1 M. Górak, Cyfrowa prasa: chwilowa moda czy przyszłość, http://internetstandard.pl/artykuły/ 45301.html (dostęp: 6.12.2004).

Tekst podstawowy i przypisy: wyjustowane.

Ustawienia strony: standardowe.

Objętość: 25-35 tys. znaków (wraz ze spacjami).

W celu przeciwdziałania „ghostwriting” i „guest authorship” Redakcja „Studiów Politologicznych" wprowadziła procedury związane z zaporą "shostwriting”. 
„Ghostwriting” oraz "guest authorship” są przejawem nierzetelności naukowej. Wszelkie wykryte przypadki będą demaskowane, włącznie z powiadomieniem odpowiednich podmiotów (instytucje zatrudniające Autorów, towarzystwa naukowe, stowarzyszenia edytorów naukowych itp.).

Z „ghostwriting” mamy do czynienia wówczas, gdy ktoś wniósł istotny wkład w powstanie publikacji, bez ujawnienia swojego udziału jako jeden z Autorów lub bez wymienienia jego roli w podziękowaniach zamieszczonych w publikacji.

Z „guest authorship” (,honorary authorship”) mamy do czynienia wówczas, gdy udział Autora jest znikomy lub w ogóle nie miał miejsca, a pomimo to jest Autorem/współautorem publikacji.

Autor publikacji jest zobligowany poinformować o źródłach finansowania publikacji, wkładzie instytucji naukowo-badawczych, stowarzyszeń i innych podmiotów (,financial disclosure").

Redakcja «Studiów Politologicznych»wymaga od Autorów publikacji ujawnienia wkładu poszczególnych Autorów w powstanie publikacji (z podaniem afiliacji oraz informacji, kto jest Autorem koncepcji, założeń, metod, protokołu itp. wykorzystywanych przy przygotowaniu publikacji). Autor ponosi odpowiedzialność za zgłoszoną publikację.

Redakcja «Studiów Politologicznych» dokumentuje wszelkie przejawy nierzetelności naukowej, zwłaszcza łamania i naruszania zasad etyki obowiązujących w nauce.

Teksty przekazywane do opublikowania w «Studiach Politologicznych» podlegają postępowaniu recenzyjnemu. W ciągu 2 miesięcy od złożenia tekstu Autor jest informowany o zakwalifikowaniu go do postępowania recenzyjnego lub odrzuceniu ze względu na uchybienia formalne. Następnie każda praca (po nadaniu jej anonimowości) jest opiniowana przez jednego z Redaktorów «Studiów Politologicznych». Po uzyskaniu pozytywnej opinii, tekst jest przekazywany dwóm recenzentom zewnętrznym, tj. spoza członków Redakcji. W przypadku uzyskania recenzji negatywnej informacja o tym fakcie jest podawana Autorowi, a postępowanie publikacyjne ulega zakończeniu ze skutkiem dlań negatywnym. W przypadku recenzji negatywnej Autor otrzymuje recenzję nadesłanego tekstu (po usunięciu personaliów recenzenta) oraz informację, że postępowanie publikacyjne uległo zakończeniu ze skutkiem negatywnym.

Redakcja nie zwraca tekstów niezamówionych oraz zastrzega sobie prawo do ich redagowania i skracania. 


\section{STUDIA POLITOLOGICZNE \\ („ПОЛИТОЛОГИЧЕСКИЕ ИССЛЕДОВАНИЯ”)}

Указания для Авторов

Форма предоставления текстов (на русском языке): по электронной почте, в редакторе Word (на адрес секретаря «Политологических исследований»: zalesnyjacek@ gmail.com).

К тексту прилагается заявление об оригинальности работы и о том, что на данное время она не заявлена в другие издания.

Редактирование текста

\section{Схема статьи:}

\section{Автор \\ Hомер ORCID}

Название статьи на русском языке

Резюме: до 600 знаков на русском языке

Ключевые слова: 5 на русском языке

Текст статьи

Структура:

Введение: обоснование выбора темы и ее новизны, цели анализа, гипотезы и тезисы исследований, применяемые методы исследования

- анализ

- выводы

Название статьи на английском языке

Резюме: до 600 знаков на английском языке

Ключевые слова: 5 на английском языке

Библиография

Информация об авторе (наименование учреждения, в котором он работает, ученое звание, ученая степень).

Шрифт: Times New Roman «13»

Сноски: внизу страницы, непрерывная нумерация, шрифт «10», согласно образцу:

${ }^{1}$ И.В. Чубыкин, Государственное управление стран ближнего зарубежья России, Москва 2006, с. 99.

1 Там же, с. 27.

${ }^{1}$ См.: Н. Дж. Мельвин, Узбекистан: переход к авторитаризму на шелковом пути, [в:] С.И. Кузнецова (ред.), Страны Центральной Азиинарубеже ХХ-ХХІ веков: становление национальных государств, Москва 2006, с. 78.

1 А. С. Автономов, Процесс становления парламентаризма в Казахстане, «Представительная власть» 1995, № 2, с. 27.

${ }^{1}$ M. Górak, Cyfrowa prasa: chwilowa moda czy przyszłość, http://internetstandard.pl/ artykuły/45301.html (дата обращения: 6.12.2004).

Параметры страницы: стандартные

Объем: 25-35 тыс. знаков с пробелами. 
С целью противодействия «ghostwriting» и «guest authorship» редакция «Studiów Politologicznych» ввела процедуры, связанные с преградой «ghostwriting».

«Ghostwriting» и «guest authorship» являются проявлением научной недобросовестности. Все обнаруженные случаи будут разоблачены, включая уведомление соответственных субъектов (учреждений, в которых работают авторы, научные общества, сообщества научных редакторов и т.п.).

C «ghostwriting» имеем дело, когда кто-то внес весомый вклад в создание публикации, не сообщая о своем участии в роли соавтора либо без упоминания его роли в благодарностях, помещенных в публикации.

C «guest authorship» («honorary authorship») имеем дело, когда участие автора мизерно мало либо вообще отсутствует, и не смотря на это, он является автором/ соавтором публикации.

Автор публикации обязан сообщить об источниках финансирования публикации, вкладе научно-исследовательских учреждений, обществ и других субъектов («financial disclosure»).

Редакция «Studiów Politologicznych» требует от авторов публикаций представления вклада всех конкретных авторов в создании публикации (с указанием аффилиации и данных, кто является автором концепции, основных тезисов, методов, протокола и т. п., использованных в подготовке публикации). Автор несет ответственность за заявленную публикацию.

Редакция «Studiów Politologicznych» документирует все проявления научной недобросовестности, в частности нарушения принципов этики, действующих в науке.

Тексты, направляемые для публикации в «Studiach Politologicznych», подлежат процессу рецензирования. В течение 2 месяцев с момента подачи текста автор уведомляется о том, что он допущен к процессу рецензирования либо не допущен в связи с формальными погрешностями. Далее каждая работа (после ее анонимизации) оценивается одним из редакторов «Studiów Politologicznych». После получения положительной оценки текст передается двум независимым рецензентам, не являющимся членами редакции. В случае отрицательной рецензии, данную информацию сообщают автору, а процесс публикации завершается с негативным результатом. В случае негативной рецензии автор получает рецензию на отправленный текст (после удаления имени рецензента) и информацию, что процесс публикации завершен с негативным для него результатом.

Редакция не возвращает не заказанных текстов и оставляет за собой право к их редактированию и сокращению. 


\section{STUDIA POLITOLOGICZNE \\ ("POLITICAL SCIENCE STUDIES")}

\section{Instructions for Authors}

Manuscripts should be submitted by email in Word format to the Secretary of "Political Science Studies": zalesnyjacek@gmail.com

A declaration confirming the original character of the paper and that it is not under consideration for publication elsewhere must be included.

Editing of the text

Structure of the paper:

A scheme of the analysis:

Author(s)

ORCID number

Manuscript title

Abstract (up to 600 characters)

Key words: up to 5

Body of the the manuscript

Introduction: justification of the research and its novelty, objectives of the analysis, hypotheses and research theses, applied research methods

- analysis

- conclusions

Bibliography

A short note about the Author(s) is also required (including the name of the institution where they are employed, the academic title and academic degree).

Font: 13-point font size (Times New Roman)

References: at the bottom of the page, continuous pagination, 10-point font size, according to the following model:

1 F. Millard, Elections, Parties and Representation in Post-Communist Europe, Palgrave Macmillan 2004, p. 135.

1 Ibidem, p. 27.

1 T. Zittel, Legislators and their representational roles: strategic choices or habits of the heart?, [in:] M. Blomgren, O. Rozenberg (eds.), Parliamentary Roles in Modern Legislatures, Routledge 2012, p. 107.

1 F. Millard, Elections, Parties..., p. 176.

1 A. Grant, The Politics of American Campaign Finance, "Parliamentary Affairs" 1998, № 2, p. 227.

1 M. Górak, Cyfrowa prasa: chwilowa moda czy przyszłość, http://internetstandard.pl/artykuły/45301.html (access: 6.12.2004).

Page setup: standard

Length: 25,000-35,000 characters (spaces included). 
To counteract „ghostwriting” and „guest authorship”, the Editorial Board of «Studia Politologiczne» has procedures to block „ghostwriting” and unacknowledged guest authorship. „Ghostwriting” and „guest authorship” are scientifically unreliable and dishonest. All detected cases will be disclosed, including notifying the proper entities (institutions employing the Authors, scientific societies, associations of scientific editors, etc.).

We are dealing with "ghostwriting” when a person who has made a significant contribution to the manuscript does not disclose their participation as one of the Authors or when their role is not mentioned in the Acknowledgements included in the publication.

We are dealing with „guest authorship” (,honorary authorship”) when the Author's participation is negligible or none despite the fact they are listed as an Author/co-author of the publication.

The Author(s) is obliged to disclose the sources of financing for the publication, such as research grants from scientific and research institutions, associations and other entities (,financial disclosure").

The Editorial Board of "Studia Politologiczne" requires all Authors with reasonable claims to authorship to be named, including their institutional affiliations. The Authors should declare their contribution(s) to the manuscript including the development of the concept(s), assumption(s), method(s), protocols for data analysis, interpretation and conclusions. This information can be provided in a separate note (email) to the Secretary of "Political Science Studies".

The Editorial Board of "Studia Politologiczne" documents all signs of scientific unreliability, especially of breaking and infringing the principles of ethics binding in science. Manuscripts submitted for publication in "Studia Politologiczne" are subject to a doubleblind review. Within two months from the time of submission, the Author is advised if their paper has been accepted for review or rejected due to formal faults. Next, each manuscript (after being anonymized) is assessed by one of the Editors of "Studia Politologiczne". After receiving a positive opinion, it is then passed on to two external reviewers, i.e. from outside the Editorial Board. In case of a negative review, that is, the manuscript being rejected for publication, the Author is advised accordingly and the paper, along with the anonymized reviewers' feedback, is returned to them.

The Editorial Board does not return the manuscripts which have not been requested and reserves the right to edit and abridge them. 

